\title{
Lexicon of New Formal Geologic Names of the United States 1976-1980
}

U.S. GEOLOGICAL SURVEY BULIETIN 1564

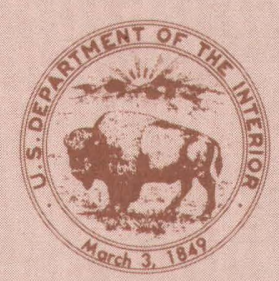





\title{
Lexicon of New Formal Geologic Names of the United States 1976-1980
}

\author{
By GWENDOLYN W. LUTTRELL, MARILYN L. HUBERT, \\ and VIRGINIA M. JUSSEN
}

U.S. GEOLOGICAL SURVEY BULLETIN 1564

A compilation of the new geologic names introduced into the literature from 1976 to 1980 in the United States, Puerto Rico, Panama Canal Zone, and American Samoa

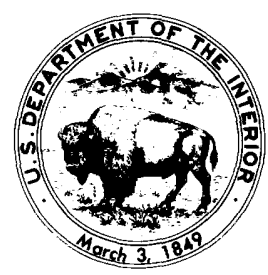




\author{
DEPARTMEN'T OF 'THE INTERIOR \\ DONALD PAUL HODEL, Secretary
}

\author{
U.S. GEOLOGICAL SURVEY \\ Dallas L. Peck, Director
}

\title{
Library of Congress Cataloging-in-Publication Data
}

Luttrell, Gwendolyn Lewise Werth, 1927-

Lexicon of new formal geologic names of the United States, 1976-1980.

(U.S. Geological Survey bulletin ; 1564)

"A compilation of the new geologic names introduced into the literature from 1976-1980 in the United States, Puerto Rico, Panama Canal Zone, and American Samoa."

Supt. of Docs. no.: I. 19.3:1564

1. Geology, Stratigraphic-Nomenclature-United States. I. Hubert, Marilyn L. II. Jussen, Virginia M. III. Title. IV. Series.

$\begin{array}{lccccc}\text { QE75.B9 } & \text { no. } 1564 & 1986 & 557.3 & \text { s } & 85-600349 \\ \text { [QE645] } & {\left[551.7^{\prime} 00973\right]} & & & & \end{array}$

For sale by the Distribution Branch, U.S. Geological Survey, 604 South Pickett Street, Alexandria, VA 22304 


\section{CONTENTS}

Introduction $\ldots \ldots \ldots \ldots \ldots \ldots \ldots \ldots \ldots \ldots \ldots \ldots$

Selection of names for the lexicon $\ldots \ldots \ldots \ldots \ldots \ldots \ldots \ldots$

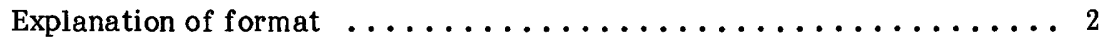

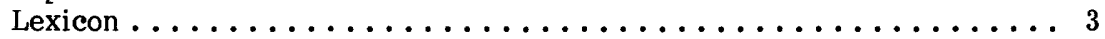

\section{TABLE}

Major geochronologic and chronostratigraphic

Page units in use by the U.S. Geological Survey

with age estimates of boundaries IV 


\section{Major geochronologic and chronostratigraphic units in use by the U.S. Geological Survey with age estimates of boundaries}

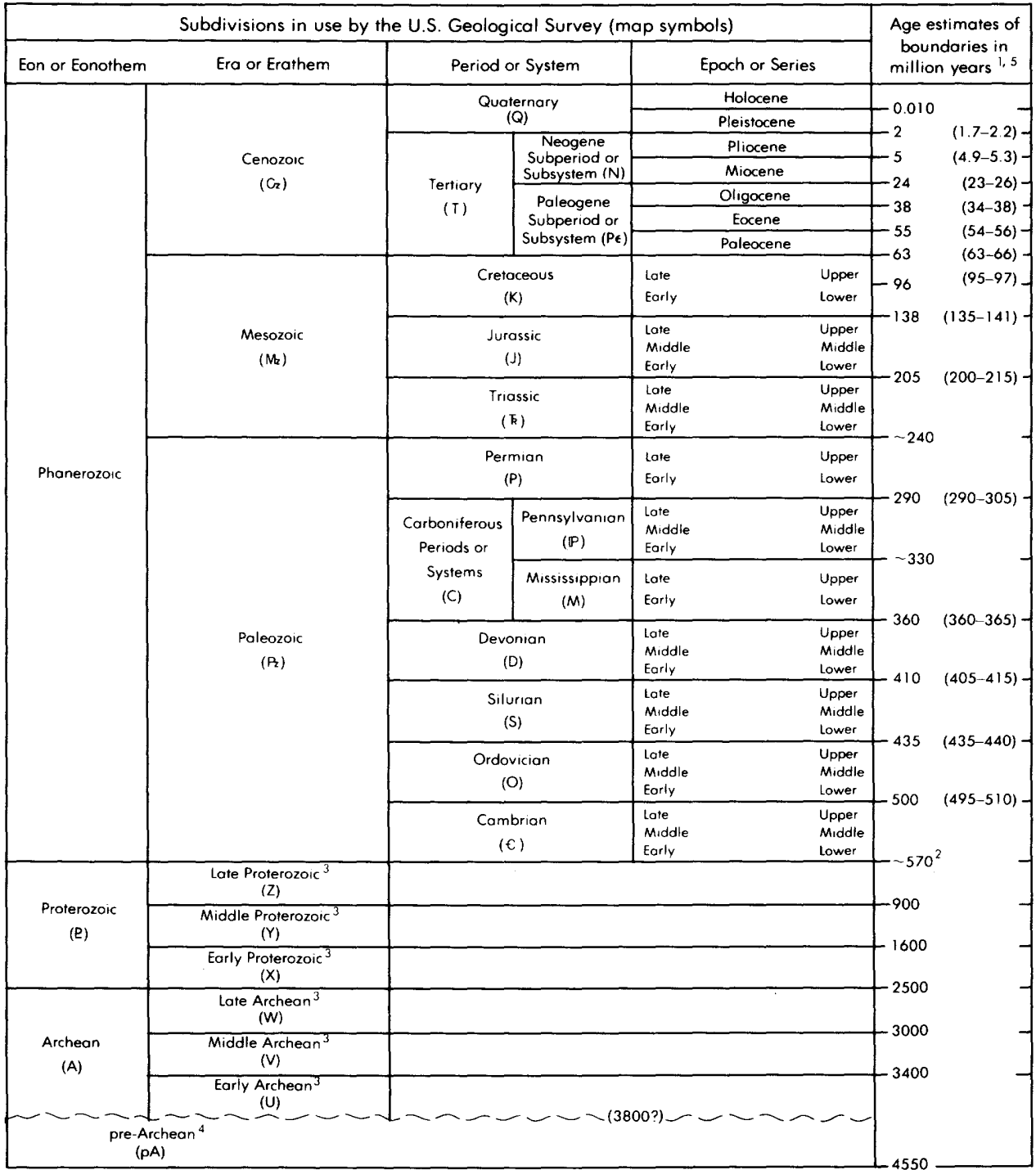

1 Ranges reflect uncertainties of isotopic and biostratigraphic age assignments. Age of boundaries not closely bracketed by existing data shown by $\sim$. Deeay constants and isotopic ratios employed are cited in Steiger and Jäger (1977).

2 Rocks older than 570 Ma also called Precambrian (pe), a time term without specific rank.

3 Geochronometric units.

4 Informal time term without specific rank.

5 Age estimates for the Phanerozoic are by G. A. lzett, M. A. Lanphere, M. E. Mac Lachlan, C. W. Naeser, J. D. Obradovich, Z. E. Peterman, M. Rubin, T. W. Stern, and R. E. Zartman at the request of the Geologic Names Committee. Age estimates for the Precambrian are by International Union of Geological Sciences Working Group on the Precambrian for the United States and Mexico, J. E. Harrison, Chairman. The chart is intended for use by members of the U.S. Geological Survey and does not constitute a formal proposal for a geologic time scale. Estimates of ages of boundaries were made after reviewing published time scales and other data. Future modification of this chart will undoubtedly be required. The general references apply where references are not given for specific boundaries. 


\section{GENERAL REFERENCES}

American Association of Petroleum Geologists, 1978, Studies in Geology 6, $388 \mathrm{p}$.

Berggren, W. A., 1972, Lethaia, v. 5, no. 2, p. 195-215.

Evernden, J. F., Savage, D. E., Curtis, G. H., and James, G. T., 1964, American Journal of Science, v. 262, p. 145-198.

Geological Society of London, 1964, Quarterly Journal, v. 120S, 458 p.

Lambert, R. S., 1971, Geological Society of London, Special Publications 3, Part 1, p. 9-31.

Steiger, R. H., and Jager, E., 1977, Earth and Planetary Science Letters, v. 36 , p. $359-362$.

Holocene-Pleistocene boundary

Hopkins, D. M., 1975, Geology, v. 3, p. 10.

\section{Pleistocene-Pliocene boundary}

Haq, B. U., Berggren, W. A., and Van Couvering, J. A., 1977, Nature, v. 269, p. 483-488.

Selli, R., Accorsi, C. A., Bandini, M. M., Bertolani, M. D., Bigazzi, G., Bonadonna, F. P., Borsetti, A. M., Cati, F., Colalongo, M. L., D'onofrio, S., Landini, W., Menesini, E., Mezzetti, R., Pasini, G., Savelli, C., and Tampieri, R., 1977, Giornale di Geologica Bologna, ser. 2, v. 42, no. 1, book II, p. 181-204.

Pliocene-Miocene boundary

Cita, M. B., 1975, Micropaleontology, Special Publication 1, p. 1-30.

McDougall, I., and Page, R. W., 1975, Micropaleontology Special Publication 1, p. 75-84.

Tongiorgi, E., and Tongiorgi, M., 1964, Nature, v. 201, p. 365-367.

Van Couvering, J. A., 1972, in Bishop, w. W., and Miller, J. A., eds., Calibration of hominid evolution, Scottish Academic Press and University of Toronto Press, p. 247-271.

Miocene-Oligocene boundary

Van Couvering, J. A., 1978, Geology, v. 6, p. 169.

Van Couvering, J. A., and Berggren, W. A., 1977, in Kauffman, E. G., and Hazel, J. E., eds., Concepts and methods of biostratigraphy, Stroudsburg, Pa.; Dowden, Hutchinson, \& Ross New York; exclusive distributor: Halstead Press, c. 1977.

\section{Oligocene-Eocene boundary}

Hardenbol, J., and Berggren, W. A., 1978, American Association of Petroleum Geologists Studies in Geology 6, p. 213-234.

Odin, G. S., Curry, D., and Hunziker, J. C., 1978, Journal of the Geological Society of London, v. 135, p. 481-497.

Eocene-Paleocene boundary

Berggren, W. A., McKenna, M. C., Hardenbol, J., and Obradovich, J. D., 1978, Journal of Geology, v. 86, p. 67-81.

Fitch, F. J., Hooker, P. J., Miller, J. A., and Brereton, N. R., 1978, Journal of the Geological Society of London, v. 135, p. 499-512.

Odin, G. S., Curry, D., and Hunziker, J. C., 1978, Journal of the Geological Society of London, v. 135, p. 481-497.

\section{Paleocene-Cretaceous boundary}

Lerbekmo, J. F., Evans, M. E., and Baadsgaard, H., 1979, Nature, v. 279, p. 26-30.

Obradovich, J. D., and Cobban, W. A., 1975, Geological Association of Canada Special Paper 13, p. 31-54. 


\section{Late-Early Cretaceous boundary}

Folinsbee, R. E., Baadsgaard, H., and Cumming, G. L., 1963, National Research Council Publication 1075, p. 70-82.

Obradovich, J. D., and Cobban, W. A., 1970, Geological Association of Canada Special Paper 13, p. 31-54.

\section{Cretaceous-Jurassic boundary}

Lanphere, M. A., and Jones, D. L, 1978, American Association of Petroleum Geologists Studies in Geology 6, p. 259-268.

\section{Jurassic-Triassic boundary}

Armstrong, R. L., and Besancon, J., 1970, Eclogae Geologicae Helvetiae, v. 63 , no. 1 , p. $15-28$.

White, W. H., Erickson, G. P., Northeote, K. E., Dirom, G. E., and Harakal, J. E., 1967, Canadian Journal of Earth Sciences, v. 4, p. 677-690.

Triassic-Permian boundary

Webb, A. W., and McDougall, I., 1967, Earth and Planetary Science Letters 2, p. 483-488.

\section{Permian-Carboniferous boundary}

Fitch, F. J., Miller, J. A., and Williams, S. C., 1970, International Congress on Stratigraphy and Carboniferous Geology, 6th, Sheffield, 1967, Compte Rendu, v. 2, p. 771-789.

\section{Carboniferous-Devonian boundary}

Fitch, F. J., Miller, J. A., and Williams, S. C., 1970, International Congress on Stratigraphy and Carboniferous Geology, 6th, Sheffield, 1967, Compte Rendu, v. 2, p. 771-789.

McDougall, I., Compston, W., and Bofinger, V. M., 1966, Geological Society of America Bulletin, v. 77, p. 1075-1088.

Talent, J. A., 1975, in Boucot, A. J., Evolution and extinction rate controls, Amsterdam, New York: Elsevier Scientific Pub. Co., p. 63.

\section{Devonian-Silurian boundary}

Ross, R. J., Jr., Naeser, C. W., Izett, G. A., Whittington, H. B., Hughes, C. P., Rickards, R. B., Zalasiewicz, J., Sheldon, P. R., Jenkins, C. J., Cocks, L. R. M., Bassett, M. G., Toghill, P., Dean, W. T., and Ingham, J. K., 1978, U.S. Geological Survey Open-File Rept. 78-701, p. 363-365.

\section{Silurian-Ordovican boundary}

Lanphere, M. A., Churkin, M., Jr., and Eberlein, G. D., 1977, Geological Magazine, v. 114, no. 1, p. 15-24.

Ross, R. J., Jr., Naeser, C. W., Izett, G. A., Whittington, H. B., Hughes, C. P., Rickards, R. B., Zalasiewicz, J., Sheldon, P. R., Jenkins, C. J., Cocks, L. R. M., Bassett, M. G., Toghill, P., Dean, W. T., and Ingham, J. K., 1978, U.S. Geological Survey Open-File Rept. 78-701, p. 363-365.

Precambrian subdivisions

Harrison, J. E., 1980, Geological Society of America Bulletin, v. 91, no. 6, p. 377-380.

Harrison, J. E., and Peterman, Z. E., 1982, American Association of Petroleum Geologists Bulletin, v. 66, no. 6, p. 801-802.

\section{Proterozoic subdivisions}

James, H. L., 1972, American Association of Petroleum Geologists Bulletin, v. 56, p. $1128-1133$.

\section{Proterozoic-Archean boundary}

James, H. L, 1978, Precambrian Research, v. 7, no. 3, p. 193-204.

\section{Archean}

Goldich, S. S., and Wooden, J. L., 1978, in Smith, I. E. M., and Williams, J. G., eds., Proceedings of the 1978 Archean Geochemistry Conference, p. 285-318. 


\section{LEXICON OF NEW FORMAL GEOLOGIC NAMES \\ OF THE UNITED STATES \\ 1976-1980}

By Gwendolyn W. Luttrell, Marilyn L. Hubert, and Virginia M. Jussen

\section{INTRODUCTION}

This lexicon contains brief descriptions of new formal stratigraphic units in the United States, Puerto Rico, Panama Canal Zone, and American Samoa introduced into the literature in the years 1976 through 1980 . This volume is the latest in a series of lexicons published by the U.S. Geological Survey as a means of keeping the geologic profession informed of the status of geologic names in the United States.

The following publications list the geologic names introduced in the United States before 1976:

Wilmarth, M. G., 1938, Lexicon of geologic names of the United States: U.S. Geological Survey Bulletin 896, two volumes.

Wilson, Druid, Sando, W. J., and Kopf, R. W., 1957, Geologic names of North America introduced in 1936-1955: U.S. Geological Survey Bulletin 1056-A, 405 p.

Keroher, G. C., and others, 1966, Lexicon of geologic names of the United States for 1936-1960: U.S. Geological Survey Bulletin 1200, three volumes.

Keroher, G. C., 1970, Lexicon of geologic names of the United States for 1961-1967: U.S. Geological Survey Bulletin 1350,848 p.

Luttrell, G. W., Hubert, M. L., Wright, W. B., Jussen, V. M., and Swanson, R. W., 1981, Lexicon of geologic names of the United States for 1968-1975: U.S. Geological Survey Bulletin 1520, 342 p.

Swanson, R. W., Hubert, M. L., Luttrell, G. W., and Jussen, V. M., 1981, Geologic Names of the United States through 1975: U.S. Geological Survey Bulletin 1535, 643 p.

\section{SELECTION OF NAMES FOR THE LEXICON}

The North American Commission on Stratigraphic Nomenclature, recognizing the desirability of uniform usage in stratigraphic classification and terminology throughout the continent of North America, formulates a code of recommended procedures for classifying and naming stratigraphic units. The 1970 Code of Stratigraphic Nomenclature, which was in effect in the years 1976 to 1980 , states that proper establishment of a formal geologic name requires publication, in a recognized scientific medium, of a definition that includes a statement of intention to designate a formal unit, selection of a name, definition of the unit in the type area with specific location of the type section, statement of distinguishing characteristics, definition of boundaries and contact relationships, description of dimensions and shape, statement of geologic age, and correlation. We have attempted to include in this lexicon only names that meet these criteria. However, some names that 
have become established in the literature through use, although not formally proposed, are included because they seem to have been intended as formal names. Names proposed in abstracts, theses, and geologic guidebooks that are not part of a regularly issued and widely distributed formal series or names used only in figures, tables, and map explanations are not included. The descriptions contain data presented in the naming papers only. Subsequent revisions or age changes are not noted.

\section{EXPLANATION OF FORMAT}

The format of this lexicon presents in a telegraphic style all information necessary for proper establishment of a formal stratigraphic unit. Each name has been described by following an outline format with 10 numbered categories. A key to the format and an explanation of abbreviations and conventions used in the text follow.

Name (not numbered).-The name of a stratigraphic unit consists of a geographic name and a rank or descriptive term. Alternate or additional rank or descriptive terms are separated from the first by a $" / . "$ Boldface type indicates U.S. Geological Survey usage.

1. Age.-Designated by era, period, or epoch terms. Stage terms are in parentheses. Where only dates are given in a reference, we have substituted the corresponding era or period term. Equivalent ages supplied by us are in brackets [].

2. Geographic extent.-The State or country in which the unit was first described, followed, in parentheses, by the geographic area of the State in which the type locality occurs. Then follow the other States in which the unit is described. The geographic areas were established by constructing a rectangle framed by the maximum and minimum latitudes and longitudes of a State and by dividing length and height by 3 to give 9 equal areas: NW, NC, NE, EC, C, WC, SW, SC, and SE. Not all these areas are present in some irregularly shaped States.

3. Reference.-The first published article that contains a formal proposal or good description of the new name.

4. Lithology.--A brief description of principal rock types found in the unit.

5. Color.-The principal colors of the unit.

6. Thickness.--In meters at the type section. A range is given if stated.

7. Distinctive features, texture, structure, environment of deposition.

8. Subdivisions.-Both formally named and informal subdivisions, from older to younger.

9. Adjoining units.--Including type of contact, if known, from older to younger; correlations.

10. Type section, locality or area, and derivation of name. 


\section{LEXICON}

Aggie Brown Member (Oahe Formation)

1. Pleistocene (Wisconsinan) and Holocene

2. North Dakota (C)

3. Clayton, Lee, Moran, S. R., and Bickley, W. B., Jr., 1976, Stratigraphy, origin, and climatic implications of late Quaternary upland silt in North Dakota: North Dakota Geol. Survey Misc. Ser., no. 54, p. 3-5

4. Silt, clay, and sand

5. Light-brown, dark-gray

6. $0.35 \mathrm{~m}$, range $0.1-0.5 \mathrm{~m}$

7. Charcoal and red baked zones caused by forest fires

9. Overlies Mallard Island Member; underlies Pick City Member

10. Type section: Riverdale Section, bluffs of Lake Sakakawea, center sec. 22, T. $147 \mathrm{~N} .$, R. 84 W., $4 \mathrm{~km} \mathrm{~N}$ of Riverdale, McLean County, N. Dak. Named for Aggie Brown Coulee, which flows into Lake Sakakawea.

Alburnett Formation

1. Pleistocene (pre-Illinoian)

2. Iowa (EC)

3. Hallberg, G. R., 1980, Pleistocene stratigraphy in eastcentral Iowa: Iowa Geol. Survey Tech. Inf. Ser., no. 10, p. 70-93

4. Till, fluvial sediments, paleosols

5. Yellowish-brown to dark-gray

6. $10 \mathrm{~m}$, range $<1-76 \mathrm{~m}$

7. Loam-textured till high in expandable clays, kaolinite, and illite

8. Several till units separated by silt, sand, and gravel, organic material and paleosols

9. Unconformably overlies Paleozoic bedrock; unconformably underlies Wolf Creek Formation

10. Type section: Little Paha core section, in roadcut through center of small paha, near town of Alburnett, NW1/4NW1/4SW1/4SW1/4 sec. 17, T. 85 N., R. 7 W., Linn County, Iowa.

A-L Peak Rhyolite

1. Oligocene

2. New Mexico (WC)

3. Deal, E. G., and Rhodes, R. C., 1976, Volcano-tectonic structures in the San Mateo Mountains, Socorro County, New Mexico: New Mexico Geol. Soc. Spec. Pub. 5, p. 54

4. Rhyolite ash-flow tuff

5. Gray to purple

6. $700 \mathrm{~m}$, range $50-700 \mathrm{~m}$

7. Welded; foliated; erupted from Mount Withington cauldron

9. Unconformably overlies Hells Mesa Rhyolite or Vicks Peak Rhyolite; underlies Potato Canyon Rhyolite

10. Type locality: NE flank of A-L Peak, N San Mateo Mountains, secs. 33-35, T. 4 S., R. 6 W., Socorro County, N. Mex.

Anapra Sandstone

1. Early Cretaceous

2. New Mexico (SC), Texas, Mexico

3. Strain, W. S., 1976, New formation names in the Cretaceous 
at Cerro de Cristo Rey, Dona Ana County, New Mexico, Appendix 2 in Lovejoy, E. M. P., Geology of Cerro de Cristo Rey uplift, Chihuahua and New Mexico: New Mexico Bur. Mines and Mineral Resources Mem. 31, p. 81-82

4. Quartz sandstone with siliceous shale beds

5. Orange, brown

6. $53 \mathrm{~m}$

7. Thin-bedded to massive, forms high ridges

9. Conformably overlies Mesilla Valley Shale; conformably underlies Del Rio Clay

10. Type section: On E side of road to Cerro de Cristo Rey and $E$ of abandoned site of Bowen; SW1/4SE1/4SW1/4 sec. 9 ,

T. 29 S., R. 4 E., Smeltertown quadrangle, Dona Ana County, N. Mex. Named for town of Anapra.

\section{Antelope Mountain Quartzite}

1. Ordovician(?)

2. California (NW)

3. Hotz, P. E., 1977, Geology of the Yreka quadrangle, Siskiyou County, California: U.S. Geol. Survey Bull. 1436, p. 17-19

4. Quartz arenite with chert beds

5. Greenish-gray, gray, brown, tan

6. Range 1,500-1,700 m

7. Well-bedded, medium- to coarse-grained

9. Overlies Duzel Phyllite; contacts modified by faulting; underlies Cretaceous and Tertiary rocks

10. Type locality: Main ridge of Antelope Mountain, secs. 26 and 35, T. 44 N., R. 7 W., and secs. 2, 3, and 10, T. 43 N., R. 7 W., Siskiyou County, Calif.

\section{Appleton Ridge Formation}

1. Early Devonian

2. Maine (SC)

3. Bickel, C. E., 1976, Stratigraphy of the Belfast quadrangle, Maine: Geol. Soc. America Mem. 148, p. 108-110

4. Lower andalusite zone: staurolite schist; garnet zone: phyllite with minor garnet; Muzzy Ridge Member: cummingtonite-garnet schist

6. $1,200 \mathrm{~m}$

7. Bedded, sheared

8. Muzzy Ridge Member

9. Conformably overlies Bucksport Formation; in fault contact with Jam Brook Formation to SW and Penobscot Formation to NE along St. George fault. Unit was formerly informal Appleton formation of Cheney (1967)

10. Type area: Appleton Ridge, Knox and Waldo Counties, Maine.

\section{Arco Hills Formation}

1. Late Mississippian (Chesterian)

2. Idaho (SC)

3. Skipp, Betty, and others, 1979, Upper Paleozoic carbonate bank in east-central Idaho--Snaky Canyon, Bluebird Mountain, and Arco Hills Formations, and their paleotectonic significance: U.S. Geol. Survey Bull. 1486, p. 11-18

4. Interbedded limestone, mudstone, shale, siltstone, and minor sandstone

5. Medium-gray, ollve-gray, yellowish-brown, grayish-red

6. $75.7 \mathrm{~m}$, range $52-93 \mathrm{~m}$ 
7. Thin-bedded, slope-forming, fossiliferous

9. Gradationally overlies Surrett Canyon Formation; gradationally or unconformably underlies Bluebird Mountain Formation

10. Type section: Exposures in Arco Hills, $1 \mathrm{~km} \mathrm{E}$ of town of Arco, N1/2NE1/4 sec. 31, T. 4 N., R. 27 E., Butte County, Idaho.

Argusville Formation

1. Pleistocene (Wisconsinan)

2. North Dakota (EC)

3. Arndt, B. M., 1977, Stratigraphy of of fshore sediment, Lake Agassiz--North Dakota: North Dakota Geol. Survey Rept.

Inv. 60 , p. 11

4. Clay

5. Gray

6. $5.5 \mathrm{~m}$

7. Lacustrine, unbedded, with marbled appearance; contains balls of silt and pebble-loam

9. Overlies pebble-loam; conformably underlies Brenna Formation or unconformably underlies Sherack Formation; grades laterally into Huot Formation

10. Type section: Boring 2, North Dakota State Highway Dept. Structure I-29-89, Rose Coulee Bridge, SW1/4SW1/4SW1/4 sec. 26, T. 139 N., R. 49 W., Cass County, N. Dak. Named for village of Argusville.

Aroostook River Formation

1. Late Ordovician and (or) Early Silurian (Ashgillian and early Llandoverian)

2. Maine (NE)

3. Roy, D. C., and Mencher, Ely, 1976, Ordovician and Silurian stratigraphy of northeastern Aroostook County, Maine: Geol. Soc. America Mem. 148, p. 31, 48

4. Calcareous slate interlayered with graywacke and siltstone

5. Gray to green-gray

6. $600 \mathrm{~m}$

7. Thin-bedded

9. Overlies Madawaska Lake Formation; conformably underlies Frenchville Formation

10. Type area: $4.0 \mathrm{~km}$ stretch of Aroostook River beginning $8.7 \mathrm{~km}$ downstream from Maine Route 11 crossing in Ashland, Aroostook County, Maine.

Asotin Member (Saddle Mountains Basalt)

1.' Miocene, middle

2. Washington (SE), Idaho

3. Swanson, D. A., and others, 1979, Revisions in stratigraphic nomenclature of the Columbia River Basalt Group: U.S. Geol. Survey Bull. 1457-G, p. G43-G44

4. Olivine- and plagioclase-phyric basalt

6. $42 \mathrm{~m}$

7. Single thick hackly jointed flow, peperitic at top, cliffforming

9. Unconformably overlies Wilbur Creek Member; conformably underlies Welssenfels Ridge Member; locally has invasive sill-like relation to enclosing sedimentary rocks

10. Type locality: Roadcuts along Cloverland Grade, NE1/4SE1/4 
sec. 26 and NW1/4 and SW1/4 of SW1/4 sec. 25, T. 10 N., R. 45 E., $5 \mathrm{~km}$ WSW of Asotin, Asotin County, Wash.

Aurora Till Member (Wolf Creek Formation)

1. Pleistocene (pre-Illinolan)

2. Iowa (NE)

3. Hallberg, G. R., 1980, Pleistocene stratigraphy in eastcentral Iowa: Iowa Geol. Survey Tech. Inf. Ser., no. 10, p. 38-54

4. Silty till, pebble loam

5. Yellowish-brown to greenish-gray

6. Range $6-11 \mathrm{~m}$

7. Loam-textured

9. Unconformably overlies Winthrop Till Member or older units; underlies and grades into Dysart paleosol; unconformably underlies Hickory Hills Till Member

10. Type locality: Aurora drilling transect, a series of core holes on divide between Wapsipinicon and Maquoketa Rivers, $3.2 \mathrm{~km} \mathrm{SW}$ of town of Aurora, NE1/4 sec. 23, T. $90 \mathrm{~N}$. , R. 8 W., Buchanan County, Iowa.

Baada Point Member (Makah Formation)

1. Eocene, late

2. Washington (NW)

3. Snavely, P. D., Jr., and others, 1980, Makah Formation--a deep-marginal-basin sequence of late Eocene and Oligocene age in the northwestern Olympic Peninsula, Washington: U.S. Geol. Survey Prof. Paper 1162-B, p. 9-11

4. Sandstone with siltstone interbeds and calcareous concretions

5. Light-olive-gray, weathers yellow-brown

6. $120 \mathrm{~m}$

7. Thick-bedded, amalgamated turbidite beds, ridge-forming

9. Gradationally overlies and underlies unnamed strata in lower part of Makah Formation

10. Type section: Wave-cut platform and headland exposures at Baada Point, SE1/4NW1/4 sec. 12, T. 33 N., R. 15 W., Strait of Juan de Fuca, Clallam County, Wash.

Back Creek Siltstone Member (Brallier Formation)

1. Late Devonian

2. Virginia (C), West Virginia

3. Avary, K. L., and Dennison, J. M., 1980, Back Creek Siltstone Member of Devonian Brallier Formation in Virginia and West Virginia: Southeastern Geology, v. 21, no. 2, p. 121153

4. Siltstone interbedded with shale and silty shale

5. Olive-gray, weathers yellowish brown

6. $20.8 \mathrm{~m}$, range $20.8-34 \mathrm{~m}$

7. Thin- to thick-bedded, fractured, turbidite deposits

9. Base is $15-60 \mathrm{~m}$ above base of Brallier Formation

10. Type section: Roadcuts along farm road on NE side of U.S. Route 250, E of valley of Back Creek, NW flank of Lantz Mountain, Hightown quadrangle, Highland County, Va.

Balls Bluff Siltstone (Newark Group)

1. Late Triassic

2. Virginia (NE), Maryland 
3. Lee, K. Y., 1977, Triassic stratigraphy in the northern part of the Culpeper basin, Virginia and Maryland: U.S. Geol. Survey Bull. 1422-C, p. C5

4. Calcisiltite with layers of oolitic limestone, dolomite, and sandstone

5. Red

6. $40 \mathrm{~m}$, range $40-2,190 \mathrm{~m}$

7. Laminated, thick-bedded

9. Overlies Manassas Sandstone (Newark Group); underlies and intertongues with Bull Run Formation (Newark Group)

10. Type section: Exposures in gully $412 \mathrm{~m} \mathrm{~N}$. $4^{\circ} \mathrm{E}$. from flagpole of Balls Bluff National Cemetery, SE Waterford quadrangle, Loudoun County, Va.

Barboursville Conglomerate Member (Bull Run Formation)

1. Late Triassic

2. Virginia (C)

3. Lindholm, R. C., 1979, Geologic history and stratigraphy of the Triassic-Jurassic Culpeper basin, Virginia: Geol. Soc. America Bull. (pts. 1 and 2), v. 90, no. 11, p. 996 (pt. 1, summary); p. 1723-1724 (pt. 2, microfiche)

4. Silicate and arkosic sandstone conglomerate

5. Grayish-maroon matrix

6. $150 \mathrm{~m}$

7. Clasts derived from Catoctin and Fauquier Formations

10. Type locality: Exposures near original Barbour Estate (Barbour Ruins), $\mathrm{S}$ of Barboursville, Culpeper basin, Orange County, Va.

Barn Hills Member (Ely Springs Dolomite)

1. Late Ordovician

2. Utah (WC), Nevada

3. Budge, D. R., and Sheehan, P. M., 1980, The Upper Ordovician through Middle Silurian of the eastern Great Basin--Pt. 1, Introduction--historical perspective and stratigraphic synthesis; Pt. 2, Lithologic descriptions: Milwaukee Public Mus. Contr. Biology and Geology, no. 28, p. 13-15 (pt. 1); no. 29, p. 22 ( pt. 2)

4. Dolomite

5. Brownish-gray, gray

6. $48 \mathrm{~m}$

7. Microcrystalline to finely crystalline, thin- to thickbedded, laminated

9. Overlies Ibex Member; underlies Lost Canyon Member

10. Type section: Exposures $3.2 \mathrm{~km}$ NNW of Ibex Well bench mark 4779, SE1/4NW1/4 sec. 26, T. 21 S., R. 14 W., Barn Hills, Confusion Range, Millard County, Utah.

Basin Gulch Quartzite Member (Phi Kappa Formation)

1. Early Ordovician

2. Idaho (SC)

3. Dover, J. H., Berry, W. B. N., and Ross, R. J., Jr., 1980, Ordovician and Silurian Phi Kappa and Trail Creek Formations, Pioneer Mountains, central Idaho--stratigraphic and structural revisions, and new data on graptolite faunas: U.S. Geol. Survey Prof. Paper 1090, p. 10-11

4. Quartzite

5. Gray 
6. $<60 \mathrm{~m}$

7. Fine-grained, locally pebbly, containing well-sorted and well-rounded grains

9. Overlies younger rocks in thrust contact; as basal member, gradationally underlies black, graptolitic argillite of main body of Phi Kappa Formation

10. Type locality: Exposures NW of junction of Basin Gulch and Trail Creek, near $E$ edge of Rock Roll Canyon quadrangle, Blaine County, Idaho. Named for Basin Gulch, northern Pioneer Mountains.

Bass River Formation

1. Late Cretaceous

2. New Jersey (SE)

3. Petters, S. W., 1976, Upper Cretaceous subsurface stratigraphy of Atlantic Coastal Plain of New Jersey: Am. Assoc. Petroleum Geologists Bull., v. 60 , no. 1, p. 93-96

4. Clayey silt with shell fragments, occasionally cemented into massive limestone

5. Olive-gray to olive-black

6. $62 \mathrm{~m}$, range $62-126 \mathrm{~m}$

7. Subsurface; represents marine transgression

9. Unconformably overlies Potomac Group; underlies Raritan and Magothy Formations undivided

10. Type section: Transcontinental Gas Pipe Line Corporation TC 16 well, depth-interval 442-504 m, Cutts Brothers Farm, Bass River Township, Burlington County, N.J.

Bear Canyon Member (Oquirrh Formation)

1. Middle Pennsylvanian (Atokan and Desmoinesian)

2. Utah (NC)

3. Baker, A. A., 1976, Geologic map of the west half of the Strawberry Valley quadrangle, Utah: U.S. Geol. Survey Misc. Inv. Ser. Map I-931, p. 2

4. Limy to quartzitic sandstone interbedded with limestone and chert

5. Gray-to-tan, reddish-brown, black

6. $2,550 \mathrm{~m}$, range $1,200-2,550 \mathrm{~m}$

7. Fossiliferous (fusulinids)

9. Overlies Bridal Veil Limestone Member; underlies Shingle Mill Limestone Member

10. Type locality: Exposed on crest of ridge $N$ of Bear Canyon that is continuation of Wallsburg Ridge extending $W$ from SE1/4 sec. 16, T. 5 S., R. 4 E., Wasatch County, Utah.

Bear Den Member (Golden Valley Formation)

1. Paleocene

2. North Dakota (WC)

3. Hickey, L. J., 1977, Stratigraphy and paleobotany of the Golden Valley Formation (early Tertiary) of western North Dakota: Geol. Soc. America Mem. 150, p. 17-28

4. Kaolinitic claystone, mudstone, sandstone

5. White, gray, orange

6. $10.4 \mathrm{~m}$, range $6-20 \mathrm{~m}$

7. Fossiliferous, channel-facies deposits; forms barren, steep slopes

8. Informal Alamo Bluff lignite-Taylor bed

9. Conformably overlies Fort Union Formation; conformably 


\section{underlies Camels Butte Member (Golden Valley Formation) \\ 10. Type section: Section 14122, S of Blue Buttes, on tributary of Bear Den Creek, $12 \mathrm{~km}$ NW of Mandaree, NE1/4NE1/4 sec. 5, T. 150 N., R. 94 W., McKenzie County, N. Dak.}

\section{Beartrap Canyon Formation}

1. Oligocene

2. New Mexico (WC)

3. Deal, E. G., and Rhodes, R. C., 1976, Volcano-tectonic structures in the San Mateo Mountains, Socorro County, New Mexico: New Mexico Geol. Soc. Spec. Pub. 5, p. 55-56

4. Rhyolite flows and domes, tuff, mudflow breccia, clastic sedimentary rocks

6. $250 \mathrm{~m}$

7. Erupted from Mount Withington cauldron

9. Unconformably overlies Potato Canyon Rhyolite; youngest rock of Mount Withington cauldron flows

10. Type locality: Beartrap Canyon, N San Mateo Mountains, secs. 7 and 18, T. 6 S., R. 7 W., Socorro County, N. Mex.

\section{Bear Valley Formation}

1. Miocene, early and middle

2. California (C)

3. Axelrod, D. I., 1980, Contributions to the Neogene paleobotany of central California: California Univ. Pubs. Geol. Sci., v. 121, p. 19-20

4. Alternating lenses of volcanic conglomerate, sandstone, and andesite tuff

6. $240 \mathrm{~m}$

7. Poorly lithified

9. Overlies Valley Springs Formation or interfingers with Underwood Mudflow Breccia; underlies Relief Peak Formation

10. Type locality: Exposures along Lake Valley Road which departs from highway to Mount Reba Ski Bowl at Poison Canyon, Alpine County, Calif. Named for outcrops on NE wall of Bear Valley.

\section{Beaucoup Formation}

1. Late Devonian

2. Alaska (NC)

3. Dutro, J. T., Jr., and others, 1979, Beaucoup Formation, a new Upper Devonian stratigraphic unit in the central Brooks Range, northern Alaska: U.S. Geol. Survey Bull. 1482-A, p. A62-A69

4. Assorted clastic and carbonate rocks including reefs and reefoid layers

5. Black, brown, yellowish-brown

6. $150 \mathrm{~m}$, range $150-545 \mathrm{~m}$

7. Thin- to medium-bedded, fine- to very fine grained, fossiliferous

9. Unconformably overlies Skajit Limestone; conformably underlies Hunt Fork Shale

10. Type section: Section on NE side of Beaucoup Creek, secs. 19 and 20, T. 14 S., R. 20 E., Philip Smith Mountains A-1 quadrangle, central Brooks Range, Alaska.

Beaver Brook Member (Nashoba Formation)

1. pre-Silurian 
2. Massachusetts (C)

3. Bell, K. G., and Alvord, D. C., 1976, Pre-Silurian stratigraphy of northeastern Massachusetts: Geol. Soc. America Mem. 148, p. 184-185, 208, app. 1 (in pocket)

4. Sillimanitic biotite gneiss, amphibolite, schist, calcsilicate rocks

5. Medium-gray

6. $1,580 \mathrm{~m}$

7. Medium-grained, stratified, relict sedimentary structures

9. Overlies Long Pond Gneiss Member (Nashoba Formation); underlies Tadmuck Brook Schist

10. Type locality: Area bounded on NE by Mill Road and on SE by Foster Street in town of Littleton, on SW by 0ld TurnpikeLittleton County Road in towns of Boxborough and Harvard, and on NW by SE foot of Oak Hill in towns of Harvard and Littleton; Ayer, Hudson, and Westford quadrangles, Middlesex County, Mass. Derivation of name not stated.

\section{Beaver Run Member (Ontelaunee Formation)}

1. Early Ordovician

2. New Jersey (NC)

3. Markewicz, F. J., and Dalton, Richard, 1977, Stratigraphy and applied geology of the lower Paleozoic carbonates in northwestern New Jersey--Field Conference of Pennsylvania Geologists, 42d, Stroudsburg, 1977, Guidebook: [Harrisburg, Pennsylvania Geol. Survey] p. 22

4. Dolomite with chert beds

5. Black

6. Range 45-61 m

7. Sparkly, emits fetid odor when struck, massive; fossiliferous

9. Overlies Lafayette Member (Epler Formation); underlies Harmonyvale Member (Ontelaunee Formation)

10. Type section: Not stated, although unit is included in measured sections. Probably named for Beaver Run, a tributary of Wallkill River, or for village of Beaver Run, both $W$ of Hamburg, Sussex County, N.J.

\section{Belgrade Formation}

1. Miocene, early

2. North Carolina (EC)

3. Ward, L. W., Lawrence, D. R., and Blackwelder, B. W., 1978, Stratigraphic revision of the middle Eocene, Oligocene, and lower Miocene--Atlantic Coastal Plain of North Carolina: U.S. Geol. Survey Bull. 1457-F, p. F13-F16

4. Oyster-shell beds and phosphatic, calcareous, clayey, shelly quartz sands

5. Tan to orange, gray to brown

6. $3 \mathrm{~m}$, range $3-31 \mathrm{~m}$

7. Unconsolidated. Members represent penecontemporaneous nearshore and of fshore facies

8. Pollocksville and Haywood Landing Members

9. Unconformably overlies River Bend Formation; unconformably underlies Duplin Formation

10. Type locality: Martin Marietta Co. Belgrade quarry, just $E$ of intersection of County Route 1434 and U.S. Highway 17, Belgrade, Onslow County, N.C. 


\section{Belleville Tuff}

1. Oligocene, late

2. Nevada (WC)

3. Speed, R. C., and Cogbill, A. H., 1979, Cenozoic volcanism of the Candelaria region, Nevada: Geol. Soc. America Bull., Part II, v. 90 , no. 2, p. 456-493

4. Pumiceous ash-flow tuff

6. $80 \mathrm{~m}$

7. Two cooling units each with less compacted basal zone, intermediate vitrophyre, and thick compacted upper zone

10. Type locality: East flank of hills $2.3 \mathrm{~km} \mathrm{~S} .20^{\circ} \mathrm{E}$. of Belleville site, Candelaria Hills, Mineral County, Nev.

Bellows Hill Member (Nashoba Formation)

1. pre-Silurian

2. Massachusetts (C)

3. Bell, K. G., and Alvord, D. C., 1976, Pre-Silurian stratigraphy of northeastern Massachusetts: Geol. Soc. America Mem. 148 , p. 186-187, 208, app. 1 (in pocket)

4. Sillimanitic biotite gneiss with amphibolite

5. Medium-gray

6. $1,100 \mathrm{~m}$

7. Medium-grained, stratified; relict sedimentary structures

9. Overlies Boxford Member; underlies Billerica Schist Member

10. Type locality: NW part of town of Concord, $800 \mathrm{~m} \mathrm{~W}$ of junction of Lowell Road and Westford Road on $S$ and $W$ sides of Bemis Estate, Maynard quadrangle, Middlesex County, Mass. [Probably named for Bellows Hill, a hill $\mathrm{N}$ of Concord.]

\section{Benton Spring Group}

1. Oligocene

2. Nevada (WC)

3. Ekren, E. B., and others, 1980, Stratigraphy, preliminary petrology, and some structural features of Tertiary volcanic rocks in the Gabbs Valley and Gillis Ranges, Mineral County, Nevada: U.S. Geol. Survey Bull. 1464, p. 11-29

4. Rhyodacite, quartz latite, and rhyolite tuffs

5. Gray

6. Range 170-900 m

7. Multiple-flow cooling units

8. Mickey Pass Tuff with its Guild Mine and Weed Heights Members, Singatsee Tuff, and Petrified Spring Tuff

9. Overlies lavas of Giroux Valley; underlies intermediate lavas or Blue Sphinx Tuff

10. Type locality: Benton Spring, T. 9 N., R. 34 E., Gabbs Valley Range, Mineral County, Nev.

\section{Berg Creek Formation}

1. Early Cretaceous (Hauterivian and Barremian)

2. Alaska (EC)

3. Mackevett, E. M., Jr., and others, 1978, Geologic map of the McCarthy C-8 quadrangle, Alaska: U.S. Geol. Survey Geol. Quad. Map GQ-1418

4. Bioclastic sandy limestone with conglomerate

5. Light-gray, brown, greenish-gray, buff

6. $250 \mathrm{~m}$

7. Massive to medium-bedded, crossbedded, fossiliferous, nearshore marine deposits 
9. Unconformably overlies Triassic rocks or nonconformably overlies Chitina Valley batholith (Late Jurassic); gradationally underlies Kuskulana Pass Formation

10. Type section: Exposures extend $S$ from SE1/4SW1/4 sec. 34 , T. 3 S., R. 9 E., to SE1/4NW1/4 sec. 3, T. 4 S., R. 9 E., from $W$ of Berg Creek to $1.8 \mathrm{~km} S$ of Kuskulana Pass, McCarthy C-8 quadrangle, Wrangell Mountains, Alaska.

Bernhardt Mountain Member (Peck Lake Formation)

1. [Middle Proterozoic]

2. New York (EC)

3. McLelland, James, and Isachsen, Yngvar, 1980, Structural synthesis of the southern and central Adirondacks--a model for the Adirondacks as a whole and plate tectonics interpretations: Geol. Soc. America Bull. (pt. 2, microfiche), v. 91, no. 2, p. 226-227

4. Quartzofeldspathic gneiss

7. Megacrystic

9. Overlies kinzigite of Peck Lake Formation; underlies Green Lake Formation

10. Type locality: Bernhardt Mountain, NE corner Caroga Lake quadrangle, Fulton County, N.Y.

Bernice Formation

1. Late Triassic

2. Nevada (WC)

3. Speed, R. C., 1976, Geologic map of the Humboldt lopolith and surrounding terrane, Nevada: Geol. Soc. America Map and Chart Ser. MC-14, p. 2

4. Mudstone with minor wacke, quartz arenite, and limestone

6. $2,600 \mathrm{~m}$

9. Overlies Triassic pelite; conformably underlies Hoyt Canyon Formation

10. Type locality: Not stated. Probably named for exposures in Bernice Canyon, T. 22 N., R. 37 E., Clan Alpine Mountains, Churchill County, Nev.

Big Canyon Latite (Tintic Mountain Volcanic Group)

1. Oligocene, middle

2. Utah (C)

3. Morris, H. T., and Lovering, T. S., 1979, General geology and mines of the East Tintic mining district, Utah and Juab Counties, Utah: U.S. Geol. Survey Prof. Paper 1024, p. 4041

4. Latite airfall tuff and flow

5. Tuff: white-stained yellow, brown, and black; flow: medium- to dark-gray

6. Tuff: $38 \mathrm{~m}$; flow: $29 \mathrm{~m}$

7. Tuff: fine-grained, bedded, moderately to strongly altered; flow: compact, finely porphyritic, planar partings

8. Informal lower tuff member and upper flow member

9. Unconformably overlies Latite Ridge Latite (Tintic Mountain Volcanic Group) or Packard Quartz Latite; unconformably underlies Pinyon Queen Latite (Laguna Springs Volcanic Group)

10. Type locality: Latite capping E-trending ridge that marks $\mathrm{S}$ side of entrance to Big Canyon, NW1/4 sec. 13, T. $10 \mathrm{~S}$, 
R. 2 W., East Tintic Mountains, $16 \mathrm{~km} \mathrm{SW} \mathrm{of} \mathrm{East} \mathrm{Tintic}$ mining district, Juab County, Utah.

Big Creek Gneiss

1. Early Proterozoic

2. Wyoming (SC)

3. Divis, A. F., 1976, Geology and geochemistry of Sierra Madre Range, Wyoming: Colorado School Mines Quart., v. 71, no. 3, p. $14-18$

4. Hornblende and feldspathic gneiss

7. Banded and augen gneiss, foliated to granoblastic; coarsegrained pegmatites

9. In gradational contact with Sierra Madre Granite; underlies and intergrades with Green Mountain Formation

10. Type area: Exposed along banks of Big Creek and margins of Big Creek Park, SE Sierra Madre Range, Carbon County, Wyo.

Big Elk Creek Member (James Run Formation)

1. Paleozoic, early

2. Maryland (NE), Delaware

3. Higgins, M. W., 1977, Six new members of the James Run Formation, Cecil County, northeastern Maryland: U.S. Geol. Survey Bull. 1435-A, p. A126

4. Quartz-plagioclase-hornblende amphibolite and felsite

5. Dark-green, gray

6. $305 \mathrm{~m}$

7. Interlayered, layers 3-12 $\mathrm{cm}$ thick, of metavolcanic and metasedimentary origin

9. Gradationally overlies Gilpins Falls Member; probably partly equivalent to Happy Valley Branch and Principio Creek Members

10. Type section: Exposures along Big Elk Creek, Cecil County, Md.

Big Horse Limestone Menber (Orr Formation)

1. Late Cambrian

2. Utah (WC)

3. Hintze, L. F., and Palmer, A. R., 1976, Upper Cambrian Orr Formation--its subdivisions and correlatives in western Utah: U.S. Geol. Survey Bull. 1405-G, p. G4-G5, G15-G18

4. Limestone, calcarenite

5. Gray

6. $217.9 \mathrm{~m}$

7. Fossiliferous, cliff-forming

9. In type section, conformably overlies Weeks Limestone, conformably underlies Candland Shale Member (Orr Formation); in Wah Wah Mountains, overlies Wah Wah Summit Formation, conformably underlies Steamboat Pass Shale Member (Orr Formation)

10. Type section: NE side of orr Ridge, on NE face of hill 6593, SE1/4 sec. 28, T. 18 S., R. $13 \mathrm{~W} .$, and along ridge between Little Horse Canyon and Big Horse Canyon, NE 1/4 sec. 33, T. $18 \mathrm{~S} .$, R. 13 W., House Range, Notch Peak quadrangle, Millard County, Utah.

2. New Jersey (NC) 
3. Markewicz, F. J., and Dalton, Richard, 1977, Stratigraphy and applied geology of the lower Paleozoic carbonates in northwestern New Jersey--Field Conference of Pennsylvania Geologists, 42d, Stroudsburg, 1977, Guidebook: Harrisburg, Pennsylvania Geol. Survey p. 21

4. Dolomite and limestone, with bands of siliceous shale and quartzite

5. Gray, weathers red to orange or pale blue

6. Range $12-46 \mathrm{~m}$

7. Fine- to medium-grained, banded

9. Overlies Branchville Member; underlies Lafayette Member

10. Type section: Not stated, although unit is described in measured sections. Probably named for Big Spring, a spring on NW side of New Jersey Route 94 about $5 \mathrm{~km} \mathrm{SW}$ of Hamburg, Sussex County, N.J.

Billerica Schist Member (Nashoba Formation)

1. pre-Silurian

2. Massachusetts (C)

3. Bell, K. G., and Alvord, D. C., 1976, Pre-Silurian stratigraphy of northeastern Massachusetts: Geol. Soc. America Mem. 148, p. 186-187, 208, app. 1 (in pocket)

4. Sillimanite-muscovite-biotite schist

5. Weathers rusty

6. $270 \mathrm{~m}$

7. Stratified, relict sedimentary structures

9. Overlies Bellows Hill Member; underlies Spencer Brook Member

10. Type locality: SE side of Fox Hill and along Concord River from its crossing by U.S. Highway $3 \mathrm{SW}$ to vicinity of Riverside, in town of Billerica, Billerica quadrangle, Middlesex County, Mass.

\section{Black Box Dolomite}

1. Late Permian

2. Utah (EC)

3. Welsh, J. E., Stokes, W. L., and Wardlaw, B. R., 1979, Regional stratigraphic relationships of the Permian "Kaibab" or Black Box Dolomite of the Emery high, central Utah, in Baars, D. L., ed., Permianland: Four Corners Geol. Soc., Field Conf., 9th, 1979, Guidebook, p. 143-149

4. Dolomite with cherty dolomite

5. Gray

6. $26 \mathrm{~m}$, range $26-56 \mathrm{~m}$

7. Finely crystalline

9. Unconformably overlies Cedar Mesa Sandstone; unconformably underlies Black Dragon Member (Moenkopi Formation). Was described as the "Kaibab" Limestone by Gilluly and Reeside (1927) at Black Box Canyon

10. Type section: Exposures $0.8 \mathrm{~km} \mathrm{~S}$ of head of Black Box Canyon of San Rafael River, San Rafael Swell, Emery County, Utah.

Black Dyke Formation

1. Permian

2. Nevada (WC)

3. Speed, R. C., 1977, Excelsior Formation, west central Nevada--stratigraphic appraisal, new divisions, and paleogeographic interpretations, in Stewart, J. H., and others, 
eds., Paleozoic paleogeography of the western United States-Pacific Coast Paleogeography Symposium 1 [Bakersfield, CA, 1977.]: Los Angeles, Soc. Econ. Paleontologists and Mineralogists, Pacific Sec., p. 334-335

4. Mafic volcanic breccia with minor intercalated volcanogenic sedimentary rocks, lavas, and intrusive rocks

7. Allochthonous thrust nappe

9. Overlies, in thrust-fault contact, Triassic and Jurassic sedimentary rocks; unconformably underlies Tertiary volcanics intruded by Late,Cretaceous(?) granitic rocks

10. Type area: Black Dyke Mountain, E Garfield Hills, Mineral County, Nev.

\section{Blackwater Draw Formation}

1. Pleistocene (Illinoian)

2. Texas (NC), New Mexico

3. Reeves, C. C., Jr., 1976, Quaternary stratigraphy and geologic history of southern High Plains, Texas and New Mexico, in Mahaney, W. C., ed., Quaternary stratigraphy of North America: Stroudsburg, Pa., Dowden, Hutchinson and Ross, p. 219, 222

4. Sand, sandy clay loam

5. Reddish-brown to tan

6. Range $<1-27 \mathrm{~m}$

7. Eolian origin

9. Unconformably overlies "caprock" caliche of Ogallala Group or basal Illinoian gray sand; unconformably underlies Peoria(?) loess or is present at surface

10. Type section: Outcrop on $W$ side of Blackwater Draw $W$ of New Deal, lat $33^{\circ} 46^{\prime} 00^{\prime \prime}$ N., long $101^{\circ} 52^{\prime} 30^{\prime \prime}$ W., Lubbock County, Tex.

Bloom Member (Snaky Canyon Formation)

1. Late Mississippian to Late Pennsylvanian (Chesterian to Missourian)

2. Idaho (SE)

3. Skipp, Betty, and others, 1979, Upper Paleozoic carbonate bank in east-central Idaho--Snaky Canyon, Bluebird Mountain, and Arco Hills Formations, and their paleotectonic significance: U.S. Geol. Survey Bull. 1486, p. 21-28

4. Limestone interbedded with sandstone or siltstone; contains chert nodules

5. Medium-gray to medium-dark-gray

6. $647 \mathrm{~m}$

7. Ledge-forming, very fine to coarse-grained, fossiliferous

9. Gradationally overlies Bluebird Mountain Formation; gradationally underlies Gallagher Peak Sandstone Member (Snaky Canyon Formation)

10. Type section: Exposures on Gallagher Peak, secs. 29 and 30 , T. 10 N., R. 31 E., and sec. 21, T. 9 N., R. 32 E., Copper Mountain quadrangle, Clark County, Idaho. Named for Bloom triangulation station, $2.7 \mathrm{~km} \mathrm{~S}$ of Gallagher Peak.

\section{Bloomer Hill Formation}

1. Jurassic

2. California (NW)

3. Hietanen, Anna, 1977, Paleozolc-Mesozoic boundary in the Berry Creek quadrangle, northwestern Sierra Nevada, Califor- 
nia: U.S. Geol. Survey Prof. Paper 1027, p. $8-17$

4. Metavolcanic rocks including metadacite, metasodarhyolite, meta-andesite, metabasalt, metatuff, and tuffaceous metasedimentary rocks

5. Greenish-gray

6. Range $100-1,700 \mathrm{~m}$

9. In fault contact with, or unconformably overlies(?), Paleozoic rocks, including Horseshoe Bend Formation

10. Type section: WSW section across Bloomer Hill in sec. 30 , T. 21 N., R. 5 E., and continuing from there to SW along prominent ridge in secs. 25 and $26, T .21$ N., R. 4 E., and to $\mathrm{E}$ of Bloomer $\mathrm{Hill}$ in secs. 29 and 28, T. $21 \mathrm{~N} ., \mathrm{R} .5 \mathrm{E}$. , Berry Creek quadrangle, Butte County, Calif.

\section{Bluebird Mountain Formation}

1. Late Mississippian (Chesterian)

2. Idaho (SE)

3. Skipp, Betty, and others, 1979, Upper Paleozoic carbonate bank in east-central Idaho--Snaky Canyon, Bluebird Mountain, and Arco Hills Formations, and their paleotectonic significance: U.S. Geological Survey Bull. 1486, p. 18-20

4. Quartzose sandstone interbedded with dolomite and limestone

5. Medium-gray to medium-light-gray, weathers light-brown

6. $105 \mathrm{~m}$, range $7.6-105 \mathrm{~m}$

7. Very fine grained, mostly thin-bedded, cliff-forming, mostly unfossiliferous

9. Gradationally or unconformably overlies Arco Hills Formation or Big Snowy Formation; gradationally underlies Bloom Member (Snaky Canyon Formation)

10. Type section: Exposures on $\mathrm{W}$ flank of Gallagher Peak, secs. 29 and 30, T. 10 N., R. 31 E., Copper Mountain quadrangle, Clark County, Idaho. Named for Bluebird Mountain, $5.8 \mathrm{~km} \mathrm{~N}$ of type section.

\section{Blue Lake Rhyolite Member (Mount Belknap Volcanics)}

\section{Miocene}

2. Utah $(\mathrm{SC})$

3. Steven, T. A., and others, 1979, Revised stratigraphy and radiometric ages of volcanic rocks and mineral deposits in the Marysvale area, west-central Utah: U.S. Geol. Survey Bull. 1469, p. 28-29

4. Rhyolite

5. Bleached white

6. $260 \mathrm{~m}$, range $<1-500 \mathrm{~m}$

7. Wedge-shaped body with prominent, contorted flow layering

9. Overlies unnamed lower tuff member and underlies unnamed middle tuff member; units are part of intracaldera facies of Mount Belknap Volcanics

10. Type area: Cliff exposures on flanks of glaciated valley adjacent to Blue Lake, Piute County, Utah.

Blue Mountain Lake Formation

1. Proterozoic

2. New York (NE)

3. McLelland, James, and Isachsen, Yngvar, 1980, Structural synthesis of the southern and central Adirondacks--a model for the Adirondacks as a whole and plate tectonics interpretations: Geol. Soc. America Bull. (pt. 2, microfiche), v. 
91, no. 2, p. 234-235

4. Calcite marble with subordinate lenses of amphibolite

6. Range $300-1,300 \mathrm{~m}$

7. Coarse-grained

9. Overlies Lake Durant Formation; underlies Little Moose Mountain Formation; grades laterally into Tomany Mountain Formation to $S E$

10. Type locality: Blue Mountain Lake, Blue Mountain quadrangle, Hamilton County, N.Y.

\section{Blue Sphinx Tuff}

1. Oligocene or Miocene

2. Nevada (WC)

3. Ekren, E. B., and others, 1980, Stratigraphy, preliminary petrology, and some structural features of Tertiary volcanic rocks in the Gabbs Valley and Gillis Ranges, Mineral County, Nevada: U.S. Geol. Survey Bull. 1464, p. 33-36

4. Quartz latite tuff with quartz phenocrysts

5. Blue or lavender

6. $30-90 \mathrm{~m}$, range $<1-300 \mathrm{~m}$

7. Multiple-flow cooling unit

9. Overlies tuffaceous and lacustrine sedimentary rocks; underlies lava of Nugent Wash or Nugent Tuff Member (Hu-pwi Rhyodacite)

10. Type locality: Blue Sphinx monolith, $S$ of Golden Pen Mine, sec. 33, T. 11 N., R. 32 E., E flank of Gabbs Valley Range, Mineral County, Nev.

Bluestone Mine Tuff

1. Oligocene

2. Nevada (WC)

3. Proffett, J. M., Jr., and Proffett, B. H., 1976, Stratigraphy of the Tertiary ash-flow tuffs in the Yerington district, Nevada: Nevada Bur. Mines and Geology Rept. 27, p. 20-21

4. Rhyolitic vitric tuff-breccia interbedded with tuff and rhyolitic sandstone and siltstone

5. White to pale-buff

6. Range $75-270 \mathrm{~m}$

7. Unwelded to poorly welded, crystal-poor, devitrified; easily eroded, except for two well-lithified ash-flow tuffs which form ridges

9. Overlies Singatse Tuff with erosional unconformity; underlies unnamed Oligocene tuff and breccia of Gallagher Pass with erosional unconformity

10. Type area: Exposures $E$ of Bluestone Mine, NW1/4 sec. 32, NE1/4 sec. 31, SE1/4 sec. 30 , SW1/4 sec. 29, T. $13 \mathrm{~N}$. , R. 25 E., Singatse Range, Lyon County, Nev.

Boonton Formation (Newark Supergroup)

1. Early Jurassic

2. New Jersey (NE)

3. Olsen, P. E., 1980, The latest Triassic and Early Jurassic formations of the Newark Basin (eastern North America, Newark Supergroup)--stratigraphy, structure, and correlation: New Jersey Acad. Sci. Bull., v. 25 , no. 2, p. 38

4. Clastic deposits composed of siltstone, sandstone, and conglomerate; thin beds with pseudomorphs after evaporite 
minerals, "Boonton Fish Bed" fossil-fish-bearing siltstone

5. Red, brown, gray, black

6. $>500 \mathrm{~m}$

9. Overlies Hook Mountain Basalt; is youngest sedimentary unit in Newark basin. Unit was formerly uppermost part of Brunswick Formation of Kummel (1897)

10. Type section: Exposure along Rockaway River near Boonton, Morris County, N.J.

Boulder Creek Volcanics (Amphitheater Group)

1. Late Triassic

2. Alaska (EC)

3. Stout, J. H., 1976, Geology of the Eureka Creek area, eastcentral Alaska Range: Alaska Div. Geol. and Geophys.

Surveys Geol. Rept. 46, p. 14-17

4. Basalt, amygdaloidal basalt

5. Gray to green

6. $5,600 \mathrm{~m}$

7. Occupies core of E-W Amphitheater syncline

9. Overlies Tangle Lakes Formation (Amphitheater Group); upper contact not exposed (top eroded); intruded by gabbro dikes related to Fish Lake Complex

10. Type locality: Low mountains $\mathrm{N}$ of Boulder Creek and Sevenmile (Boulder) Lake, Eureka Creek area, Mount Hayes A-5 and B-5 quadrangles, Alaska.

Boxer Formation

1. Late Cretaceous

2. California (NW)

3. Ingersoll, R. V., Rich, E. I., and Dickinson, W. R., 1977, Field guide--Great Valley Sequence, Sacramento Valley:

Geol. Soc. America, Cordilleran Sec., Ann. Mtg., [Guidebook $8]$, p. $28,31-33$

4. Siltstone, conglomerate, sandstone

5. Olive-green, dark-gray

6. $1,600 \mathrm{~m}$; range $1,600-2,900 \mathrm{~m}$

7. Thin-bedded to laminated siltstone; fine-grained sandstone; mixed plutonic and volcanic detritus deposited in deepmarine trough

8. Salt Creek Conglomerate Member at base

9. Conformably overlies Lodoga Formation; conformably underlies or intertongues with Cortina Formation

10. Type section: Low hills adjacent to Boxer Valley and W- . facing slope of Cortina Ridge, Wilbur Springs quadrangle, Colusa County, Calif.

Boyd Gap Formation (Great Smoky Group)

1. Late Proterozoic(?)

2. Tennessee (SE), North Carolina

3. Wiener, L. S., and Merschat, C. E., 1978, Summary of geology between the Great Smoky fault at Parksville, Tennessee, and basement rocks of the Blue Ridge at Glade Gap, North Carolina: Tennessee Div. Geology Rept. Inv. 37, p. 26-27

4. Metasedimentary slate, phyllite, metagraywacke, and minor metaconglomerate

5. Gray

6. $2,450 \mathrm{~m} \max$.

9. Underlies informal Buck Bald formation; in contact with 
informal Farner formation, but stratigraphic relations are uncertain

10. Type section: Roadcuts along U.S. Highway 64, from 22 to 30 $\mathrm{km}$ E of Parksville, Polk County, Tenn. Named for Boyd Gap.

Bradbury Creek Granodiorite

1. Precambrian, middle

2. Minnesota (C)

3. Morey, G. B., 1978, Lower and middle Precambrian stratigraphic nomenclature for east-central Minnesota: Minnesota Geol. Survey Rept. Inv. 21, p. 35-36

4. Plagioclase-quartz-K-feldspar-hornblende granodiorite

5. Gray to black

7. Elliptical pluton $11 \mathrm{~km}$ long and $6 \mathrm{~km}$ wide, fine- to mediumgrained

9. Intrudes Hillman Migmatite

10. Type locality: Outcrops along and $\mathrm{N}$ of Bradbury Creek on $\mathrm{N}-$ $\mathrm{S}$ line between sec. 25, T. $41 \mathrm{~N} ., \mathrm{R} .27 \mathrm{~W} .$, and sec. 30 , T. 41 N., R. 26 W., Mille Lacs County, Minn.

Bradshaw Layered Amphibolite (Baltimore Mafic Complex)

1. Cambrian(?)

2. Maryland (NC)

3. Crowley, W. P., 1976, The geology of the crystalline rocks near Baltimore and its bearing on the evolution of the eastern Maryland Piedmont: Maryland Geol. Survey Rept. Inv. 27, p. $16,28,30$

4. Interlayered amphibolite and hornblende-quartz-plagioclase gneiss, with zones of massive and laminated amphibolite

9. In thrust-fault contact with Oella Formation (Wissahickon Group); underlies Franklinville Gneiss or Perry Hall Gneiss in NE-SW synclines; passes into Raspeburg Amphibolite (Baltimore Mafic Complex) on NW limb of Perry Hall syncline

10. Type locality: Outcrops along Little Gunpowder Falls on either side of 0ld Philadelphia Road (Maryland Route 7) near Bradshaw, White Marsh quadrangle, Baltimore County, Md.

Braggs Member (Sausbee Formation)

1. Early Pennsylvanian (Morrowan)

2. Oklahoma (EC)

3. Sutherland, P. K., and Henry, T. W., 1977, Carbonate platform facies and new stratigraphic nomenclature of the Morrowan Series (Lower and Middle Pennsylvanian), northeastern Oklahoma: Geol. Soc. America Bull., v. 88, no. 3, p. $429-431$

4. Limestone interbedded with shale; sandstone in lower part

6. $\quad 31.4 \mathrm{~m}$, range $12.8-53.3 \mathrm{~m}$

7. Skeletal calcarenite, fossiliferous

9. Unconformably overlies Pitkin Limestone; conformably underlies and interfingers with Brewer Bend Limestone Member (Sausbee Formation)

10. Type section: Measured Section 1, W bluff of Arkansas River, 9-183 m S from $W$ end of Webbers Falls Lock and Dam, SW1/4SW1/4SE1/4 sec. 34, T. $13 \mathrm{~N}$., R. 20 E., and Measured Section $3,0.5 \mathrm{~km}$ NW of MS 1 along river bluff, S1/2NW1/4SW1/4 sec. 34, T. $13 \mathrm{~N}$., R. $20 \mathrm{E} ., 11 \mathrm{~km} \mathrm{~S}$ of town of Braggs, Muskogee County, Okla. Probably named for 
exposures on Braggs Mountain, bluff on $E$ side of Arkansas River near town of Braggs.

Bramblett Formation

1. Pleistocene

2. Texas (WC)

3. Akersten, W. A., 1970, Red Light local fauna (Blancan) of the Love Formation, southeastern Hudspeth County, Texas: Texas Memorial Mus. Bull. 20, p. 4, 8

4. Calcareous clay, silt, sand, gravel

5. Green, yellow, brown

6. $23 \mathrm{~m}$

7. Fine-grained, lenticular, bedded, salty closed-basin deposit; vertebrate fossils

9. Lower contact not known; conformably underlies Love Formation; in fault contact with Early Cretaceous sedimentary rocks

10. Type section: Section BR-1, $1.2 \mathrm{~km}$ NNW of John D. Bramblett ranch house and $0.4 \mathrm{~km} \mathrm{NE}$ of county road to ranch, Hudspeth County, Tex.

Branchville Formation (Buffalo Wallow Group)

1. Late Mississippian (Chesterian)

2. Indiana (SC)

3. Gray, H. H., 1978, Buffalo Wallow Group--upper Chesterian (Mississippian) of southern Indiana: Indiana Geol. Survey Occasional Paper 25, p. 8-10

4. Shale with limestone beds

6. $26 \mathrm{~m}$, range $21-32 \mathrm{~m}$

8. Vienna Limestone Member at base, Leopold Limestone Member at top

9. Conformably overlies Tar Springs Formation; conformably underlies Tobinsport Formation

10. Type section: Branchville Section, SE1/4 sec. 14, T. 4 S., R. 2 W., Perry County, Ind. Named for settlement of Branchville near headwaters of 011 Creek.

Branchville Member (Epler Formation)

1. Early Ordovician

2. New Jersey (NC)

3. Markewicz, F. J., and Dalton, Richard, 1977, Stratigraphy and applied geology of the lower Paleozoic carbonates in northwestern New Jersey--Field Conference of Pennsylvania Geologists, 42d, Stroudsburg, 1977, Guidebook: [Harrisburg, Pennsylvania Geol. Survey] p. 21

4. Dolomite with chert and shale interbeds

5. Gray, weathers reddish brown to buff

6. $45 \mathrm{~m}$, range $45-94 \mathrm{~m}$

7. Fine- to coarse-grained, medium- to massive-bedded, laminated; oolites, cryptozoa

9. Overlies Hope Member (Rickenbach Formation); underlies Big Springs Member (Epler Formation)

10. Type section: Not stated. A measured section including this unit extends for about $1.6 \mathrm{~km}$ westward from abandoned Lehigh and New England Railroad right-of-way, $1200 \mathrm{~m} \mathrm{~S}$ of New Jersey Route 206 near Branchville, Sussex County, N.J. 
Brewer Bend Limestone Member (Sausbee Formation)

1. Early Pennsylvanian (Morrowan)

2. Oklahoma (EC)

3. Sutherland, P. K., and Henry, T. W., 1977, Carbonate platform facies and new stratigraphic nomenelature of the Morrowan Series (Lower and Middle Pennsylvanian), northeastern Oklahoma: Geol. Soc. America Bull., v. 88, no. 3, p. $431-432$

4. Limestone interbedded with minor shale

5. Light-gray

6. $8.7 \mathrm{~m}$, range $1.2-12.6 \mathrm{~m}$

7. Algal calcarenite (algal wackestone and mudstone), thin- to medium-bedded, nodular, fossiliferous, cliff-forming

9. Conformably overlies Braggs Member (Sausbee Formation); unconformably underlies McCully Formation

10. Type section: Measured Section 1, W bluff of Arkansas River, 9-183 m S from $W$ end of Webbers Falls Lock and Dam, SW1/4SW1/4SE1/4 sec. 34, T. 13 N., R. 20 E., and Measured Section $3,0.5 \mathrm{~km}$ NW of MS 1 along river bluff, S1/2NW1/4SW1/4 sec. 34, T. 13 N., R. 20 E., Muskogee County, Okla. Derivation of name not stated.

Bridger Peak Quartzite (Libby Creek Group)

1. Early Proterozoic

2. Wyoming (SC)

3. Divis, A. F, , 1976, Geology and geochemistry of Sierra Madre Range, Wyoming: Colorado School Mines Quart., v. 71 , no. 3 , p. 26

4. Phyllitic, feldspathic, and pure orthoquartzite; interbedded, in lower $1000 \mathrm{~m}$, with biotite-chlorite schist, conglomeratic quartzite, and phyllite

5. White to $\tan$

6. $>2,600 \mathrm{~m}$

7. Slabby to massive, cross-bedded

9. Conformably overlies Cow Creek Conglomerate; conformably underlies Copper Creek Conglomerate; lower unit $(1000 \mathrm{~m})$ lithologically similar to Heart Formation (Libby Creek Group) in Medicine Bow Range

10. Type area: Exposures in cirques in area of Bridger Peak, T. 14 N., R. 86 W., Sierra Madre Range, Carbon County, Wyo.

Bruce Creek Limestone

1. Miocene, middle

2. Florida (NW)

3. Schmidt, Walter, and Clark, M. W., 1980, Geology of Bay County, Florida: Florida Bur. Geology Bull. 57, p. 38-41

4. Argillaceous, sandy limestone

5. Pale bluish-green, white, yellow-gray

6. $0.6 \mathrm{~m}$, range $<1-91 \mathrm{~m}$

7. Moderately indurated, granular, fossiliferous, mostly subsurface

9. Unconformably overlies Chipola Formation; unconformably underlies Intracoastal Formation or Jackson Bluff Formation

10. Type locality: Exposures downstream from county road bridge over Bruce Creek, N1/2 sec. 2, T. 1 N., R. 18 W., Walton County, Fla. 


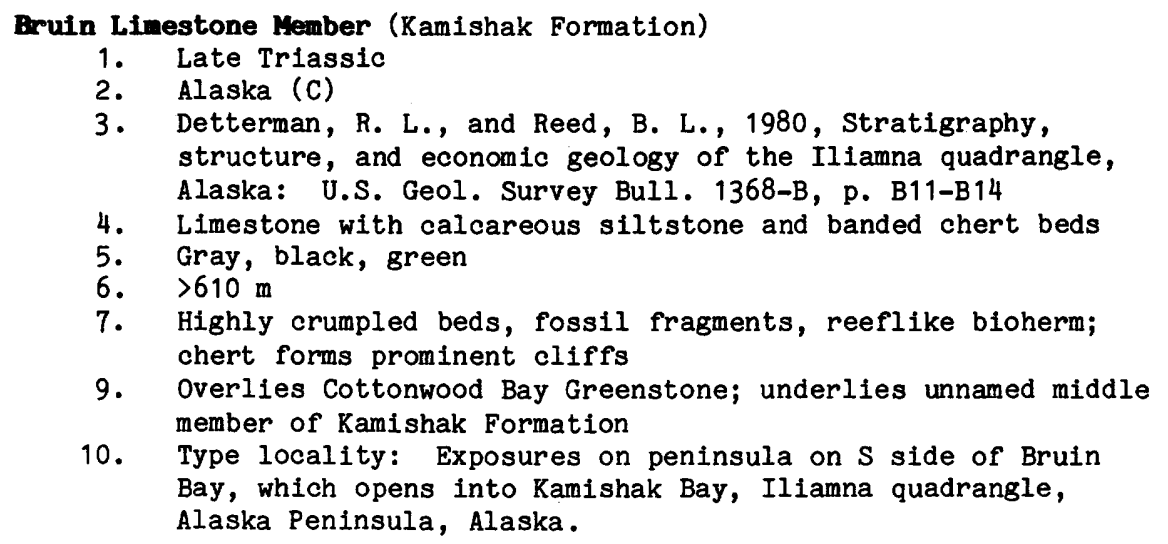

Buckland Formation

1. Early Jurassic

2. Virginia (NE)

3. Lindholm, R. C., 1979, Geologic history and stratigraphy of the Triassic-Jurassic Culpeper Basin, Virginia: Geol. Soc. America Bull. (pts. 1 and 2), v. 90, no. 11, p. 996-997 (pt. 1, summary); p. 1724-1725 (pt. 2, microfiche)

4. Basalt flows, interbedded with sandstone, mudstone, and shale

6. $1,670 \mathrm{~m}$

7. Lacustrine beds

9. Overlies Bull Run Formation; underlies Waterfall Formation

10. Type locality: Exposures along U.S. Highway 29-211 near Buckland, Culpeper basin, Prince William County, Va.

Buford Member (Saddle Mountains Basalt)

1. Miocene, middle

2. Oregon (NE), Washington

3. Swanson, D. A., and others, 1979, Revisions in stratigraphic nomenclature of the Columbia River Basalt Group: U.S. Geol. Survey Bull. 1457-G, p. G50-G51

4. Plagioclase- and olivine-phyric basalt

6. Range $20-30 \mathrm{~m}$

7. Fine- to medium-grained flow

9. Younger than Elephant Mountain Member; overlies sedimentary deposits; upper contact not stated

10. Type locality: Quarry on $E$ side of Oregon Highway $3,7.5 \mathrm{~km}$ NNE of Flora, NE1/4NE1/4 sec. 2, T. 5 N., R. 44 E., Flora quadrangle, Wallowa County, Oreg. Named for Buford Creek, which heads $\mathrm{N}$ of Flora.

Bugle Member (Keating Formation)

1. Early Mississippian

2. New Mexico (SW), Arizona

3. Armstrong, A. K., and Mamet, B. L., 1978, The Bugle and Witch Members of the Keating Formation, Escabrosa Group, and the Mississippian nomenclature in the Big Hatchet Mountains, Hidalgo County, New Mexico: U.S. Geol. Survey Bull. 1457-A, p. A92-A93

4. Limestone composed of bryozoan-echinoderm to ooid packstone and wackestone and argillaceous crinoidal-bryozoan packstone 
6. $75 \mathrm{~m}$

7. Massive-bedded, fossiliferous

9. Unconformably overlies Box Member (Percha Shale); underlies Witch Member (Keating Formation)

10. Type section: E1/2 sec. 30, T. 29 S., R. 15 W., NE side of Big Hatchet Mountains, Hidalgo County, N. Mex. Named for Bugle Ridge, Big Hatchet quadrangle.

\section{Bullfrog Member (Crater Flat Tuff)}

1. Miocene

2. Nevada (SC)

3. Byers, F. M., Jr., and others, 1976, Volcanic suites and related cauldrons of Timber Mountain-Oasis Valley caldera complex, southern Nevada: U.S. Geol. Survey Prof. Paper 919 , p. $10-11,14$

4. Ash-flow tuff

5. Brown and glassy to light-yellowish-gray

6. $280 \mathrm{~m}$, range $15-280 \mathrm{~m}$

7. Glassy, phenocrysts, single cooling unit

9. Conformably overlies bedded ash-fall tuff which overlies Redrock Valley Tuff; underlies Prow Pass Member (Crater Flat Tuff)

10. Type locality: Exposures on Bullfrog Mountain just $\mathrm{N}$ of original Bullfrog Mine, Bull frog quadrangle, Nye County, Nev.

Bullfrog Member (Lakedale Drift)

1. Pleistocene

2. Washington (C)

3. Porter, S. C., 1976, Pleistocene glaciation in the southern part of the North Cascade Range, Washington: Geol. Soc. America Bull., v. 87, no. 1, p. 70

4. Till, gravel

6. $>80 \mathrm{~m}$, range $25-80 \mathrm{~m}$

7. Moraines, outwash

8. Till and outwash facies

9. Overlies Indian John Member (Kittitas Drift); underlies Ronald Member (Lakedale Drift)

10. Type locality: Borrow pit beside $\mathrm{S}$ bank of Cle Elum River, NE1/4SW1/4 sec. 19, T. 20 N., R. 15 E., Kittitas County, Wash. Named for Bullfrog Pond, $2 \mathrm{~km}$ downstream.

Bullion Creek Formation (Fort Union Group)

1. Paleocene

2. North Dakota (SW), Montana, South Dakota

3. Clayton, Lee, and others, 1977, The Slope (Paleocene) and Bullion Creek (Paleocene) Formations of North Dakota: North Dakota Geol. Survey Rept. Inv. 59, p. 10-12

4. Alternating beds of clay, silt, sand, and lignite

5. Light-yellow; red in burned areas

6. $100 \mathrm{~m}$, range $50-200 \mathrm{~m}$

9. Unconformably overlies Slope Formation; conformably underlies Sentinel Butte Formation (all in Fort Union Group)

10. Type section: Red Hills section, SW1/4 sec. 27, SE1/4 sec. 28, NE1/4 sec. 33, NW1/4 sec. 34, T. 137 N., R. 103 W., Golden Valley County, N. Dak. Named for Bullion Creek, $5 \mathrm{~km}$ $\mathrm{N}$ of type section. 


\section{Burlington Formation}

1. pre-Silurian (late Precambrian? to Ordovician?)

2. Massachusetts (C)

3. Bell, K. G., and Alvord, D. C., 1976, Pre-Silurian stratigraphy of northeastern Massachusetts: Geol. Soc. America Mem. 148, p. 188-189, 203, app. 1 (in pocket)

4. Gneiss, quartzite, amphibolite, metamorphosed boulder conglomerate

5. White, pale-gray, dark with white pin-stripe

6. $300 \mathrm{~m}$

7. Relict sedimentary structures

9. Overlies Greenleaf Mountain Formation and Middlesex Fells Volcanic Complex; underlies Marlboro Formation

10. Type locality: NW slope of Greenleaf Mountain, NW Lexington quadrangle, Middlesex County, Mass.

Bush Bay Dolostone (Engadine Group)

1. Middle Silurian (Niagaran)

2. Michigan (EC)

3. Johnson, A. M., and others, 1979, The Maple Block knoll reef in the Bush Bay Dolostone (Silurian, Engadine Group), Northern Peninsula of Michigan: Michigan Univ. Mus. Paleontology Papers on Paleontology, no. 20, p. 14-18

4. Dolostone

5. Gray, buff, white

6. $38 \mathrm{~m}$

7. Organic reefs and interreefal facies

8. Prentiss Creek Member, Swede Road Member, McKay Bay Member

9. Overlies Rapson Creek Dolostone (Engadine Group); lies at surface or unconformably(?) underlies Pointe aux Chenes Formation (Salina Group)

10. Type area: Comprises type localities of its members, in $\mathbf{E}$ half of Mackinac County, Mich. Named for Bush Bay, which opens into Lake Huron SE of Cedarville.

Byers Canyon Formation

1. Triassic

2. Nevada (WC)

3. Speed, R. C., 1978, Basinal terrane of the early Mesozoic marine province of the western Great Basin, in Howell and McDougall, eds., Mesozoic paleogeography of the western United States: Society of Economic Paleontologists and Mineralogists, Pacific Section, Pacific Coast Paleogeography Symposium 2, p. 237-252

4. Pelitic mudstone and laminite with minor limestone, sandstone, and conglomerate

6. $>500 \mathrm{~m}$

9. Overlies undifferentiated Triassic rocks; underlies Dyer Canyon Formation, all in the Clan Alpine sequence

10. Composite type section: Clan Alpine Mountains, lat $39^{\circ} 45^{\prime}$ N., long $117^{\circ} 45^{\prime}$ W., Churchill County, Nev. Named for Byers Canyon.

Cain Formation (Salina Group)

1. Late(?) Silurian

2. Michigan (EC)

3. Briggs, L. I., and others, 1980, Transition from open marine to evaporite deposition in the Silurian Michigan basin, in 
Nissenbaum, A., ed., Hypersaline brines and evaporitic environments (Developments in Sedimentology, V. 28): Amsterdam, Elsevier Sci. Pub. Co., p. 253-270

4. Limestone, mudstone, carbonate-anhydrite varvite, halite salt

6. $10 \mathrm{~m}$

7. Starved basin and marine evaporite deposits

8. Three unnamed members: euxenic limestone; ostracode laminite (mudstone); halite-varvite (lower carbonateanhydrite varvite and upper halite)

9. Conformably overlies Lockport Formation (Niagara Group); underlies informal Salina A-1 salt, or A-1 evaporite, unit of Salina Group

10. Type section: Getty Oil Co.-Charles A. Cain et al, No. 1-21 well, depth-interval 1512-1522 m, SW1/4SW1/4SE1/4 sec. 21, T. 31 N., R. 4 E., Montmorency County, Mich.

\section{Calabasas Formation (Topanga Group)}

1. Miocene, middle

2. California ( $\mathrm{SC}$ )

3. Yerkes, R. F., and Campbell, R. H., 1979, Stratigraphic nomenclature of the central Santa Monica Mountains, Los Angeles County, California: U.S. Geol. Survey Bull. 1457-E, p. E22-E24

4. Sandstone with interbedded silty shale and sedimentary breccia

6. $1,200 \mathrm{~m}$

7. Medium- to thick-bedded, medium- to coarse-grained, graded bedding, locally diatomaceous or phosphatic, fossiliferous

8. Dry Canyon Sandstone, Escondido Canyon Shale, Latigo Canyon Breccia, Newell Sandstone, and Mesa Peak Breccia Members (these recognized only in upper plate of Malibu detachment fault, EC Point Dume and WC Malibu Beach quadrangles); and Stokes Canyon Breccia Member (in Stokes Canyon area, where Calabasas is otherwise undivided)

9. Unconformably overlies or intertongues with Conejo Volcanics (Topanga Group) or, locally, overlies Topanga Canyon Formation (Topanga Group); unconformably underlies Modelo Formation

10. Type locality: Exposures in Stokes Canyon, sec. 3, T. 1 S., R. $17 \mathrm{~W} ., 3 \mathrm{~km}$ W of Calabasas Peak, Santa Monica Mountains, NC Malibu Beach quadrangle, Los Angeles County, Calif.

Califon Member (Leithsville Formation)

1. Early Cambrian

2. New Jersey (NC)

3. Markewicz, F. J., and Dalton, Richard, 1977, Stratigraphy and applied geology of the lower Paleozoic carbonates in northwestern New Jersey--Field Conference of Pennsylvania Geologists, 42d, Stroudsburg, 1977, Guidebook: [Harrisburg, Pennsylvania Geol. Survey] p. 10-12

4. Dolomite

5. Gray, greenish-gray, weathers buff

6. $30 \mathrm{~m}$, range $12-46 \mathrm{~m}$

7. Lower part: stylolitic, ruditic, megacrystalline, fossiliferous; upper part: fine-grained to cryptogranular

9. Overlies Hardyston Formation; underlies Hamburg Member (Leithsville Formation) 
10. Type section: Abandoned quarry on $E$ side of New Jersey Route $518,2 \mathrm{~km} \mathrm{~N}$ of Califon, Hunterdon County, N.J.

Calmar Bentonite Bed (Rivoli Member of Dunleith Formation)/(Loves Park Member of Dunleith Formation, in Illinois only)

1. Middle Ordovician

2. Iowa ( $\mathrm{NE}$ ), Illinois, Minnesota

3. Willman, H. B., and Kolata, D. R., 1978, The Platteville and Galena Groups in northern Illinois: Illinois Geol. Survey Circ. 502, p. 49

4. Bentonite clay

6. $0.05 \mathrm{~m}$

9. In type section, overlies and underlies limestone units of Rivoli Member

10. Type section: Engineers old Cut Section, stream diversion channel, $2.4 \mathrm{~km}$ W of Decorah, SE1/4NE1/4 sec. 18, T. $98 \mathrm{~N}$. , R. 8 W., Winneshiek County, Iowa. Named for town of Calmar, $14.5 \mathrm{~km}$ S of type section.

Camels Butte Member (Golden Valley Formation)

1. Eocene

2. North Dakota (WC)

3. Hickey, L. J., 1977, Stratigraphy and paleobotany of the Golden Valley Formation (early Tertiary) of western North Dakota: Geol. Soc. America Mem. 150, p. 28-34

4. Montmorillonitic claystone, micaceous siltstone and sandstone, chert, conglomerate, lignite

5. Yellowish-gray to yellow-orange

6. $25.4 \mathrm{~m}$

7. Plant fossils; channel and interchannel-facies deposits; forms gentle, vegetated slopes

9. Conformably overlies Bear Den Member (Golden Valley Formation); unconformably underlies White River Group

10. Type section: Section 14117, Camels Butte, $14.5 \mathrm{~km} \mathrm{~N}$ of Dickinson, SE1/4SE1/4 sec. 27, T. 141 N., R. 96 W., Dunn County, N. Dak.

Campbell Lake Formation (Deep Lake Group)

1. Early Proterozoic

2. Wyoming (SE)

3. Karlstrom, K. E., and Houston, R. S., 1979, Stratigraphy and uranium potential of Early Proterozoic metasedimentary rocks in the Medicine Bow Mountains, Wyoming: Wyoming Geol. Survey Rept. Inv. 13, p. 15-16, 43

4. Arkosic paraconglomerate, quartz-rich phyllite, phyllitic quartzite

5. Black to dark-gray

6. $65 \mathrm{~m}$

7. Widespread deposits of possible glacial origin

9. Gradationally overlies Lindsey Quartzite; underlies Cascade Quartzite

10. Type section: $1.8 \mathrm{~km}$ SW of Campbell Lake, SW1/4SNE1/4 sec. 4, T. 15 N., R. 80 W., Medicine Bow Mountains, Carbon County, Wyo.

2. Arizona (EC) 
3. Merrill, R. K., and Péwé, T. L., 1977, Late Cenozoic geology of the White Mountains, Arizona: Arizona Bur. Geology and Mineral Technology Spec. Paper 1, p. 17-18

4. Gravelly sand diamicton

5. Brown

6. $3 \mathrm{~m}$

7. Poorly sorted, with cobbles and boulders from lavas of Mount Baldy volcano, debris flows deposited in colluvial fans, weathers to deep soil

9. Overlies Marshall Butte Member (Sheep Crossing Formation); underlies younger basaltic cinders and lava flows

10. Type section: Railroad cut $700 \mathrm{~m} \mathrm{NE}$ of Sheep Crossing, near old Sheep Crossing Campground, immediately SE of West Fork of Little Colorado River, Apache County, Ariz.

Candelaria Junetion Tuff

1. Oligocene, late

2. Nevada (WC)

3. Speed, R. C., and Cogbill, A. H., 1979, Cenozoic volcanism of the Candelaria region, Nevada: Geol. Soc. America Bull., Part II, v. 90, no. 2, p. 456-493

4. Pumiceous ash-flow tuff

5. Pink to reddish-brown

6. $100 \mathrm{~m}$

7. Basal zone of poorly compacted glassy tuff overlain by strongly compacted tuff with columnar joints, moderately compacted stony tuff, and glassy uncompacted tuff

10. Type locality: North-flowing canyon $2.15 \mathrm{~km} \mathrm{~S} .15^{\circ} \mathrm{W}$. of Candelaria Junction, Candelaria Hills, Mineral County, Nev.

\section{Candland Shale Member (Orr Formation)}

1. Late Cambrian

2. Utah (WC)

3. Hintze, L. F., and Palmer, A. R., 1976, Upper Cambrian Orr Formation--its subdivisions and correlatives in western Utah: U.S. Geol. Survey Bull. 1405-G, p. G5-G6, G13-G15

4. Limestone (calcisiltite, calcarenite), shale

5. Gray

6. $\quad 125.6 \mathrm{~m}$, range $50-125.6 \mathrm{~m}$

7. Fossiliferous, forms broad benches and slopes

9. Conformably overlies Big Horse Limestone Member; conformably underlies Johns Wash Limestone Member

10. Type section: NE side of Orr Ridge, along ridge between Little Horse Canyon and Big Horse Canyon, NE1/4 sec. 33, T. $18 \mathrm{~S} .$, R. $13 \mathrm{~W}$., House Range, Notch Peak quadrangle, Millard County, Utah. Named for exposures at mouth of Candland Canyon which drains $S$ side of Orr Ridge, $3 \mathrm{~km} \mathrm{~S}$ of type section.

\section{Carpenters Creek Tuff Member (Makah Formation)}

1. Eocene, late

2. Washington (NW)

3. Snavely, P. D., Jr., and others, 1980, Makah Formation--a deep-marginal-basin sequence of late Eocene and Oligocene age in the northwestern Olympic Peninsula, Washington: U.S. Geol. Survey Prof. Paper 1162-B, p. 12-13

4. Calcified and silicified tuff interbedded with siltstone

5. Light-yellowish-gray 
6. $1 \mathrm{~m}$

7. 7 thin water-lald tuff beds, ledge-forming

9. Overlies and underlies unnamed strata in lower part of Makah Formation

10. Type section: Exposures in Carpenters Creek, tributary of Sekiu River, NW1/4NW1/4 sec. 17, T. 32 N., R. 13 W., Clallam County, Wash.

Carrigain Syenite Porphyry (White Mountain Plutonic-Volcanic Series)

1. Jurassic and Cretaceous(?)

2. New Hampshire (C)

3. Henderson, D. M., and others, 1977, Geology of the Crawford Notch quadrangle, New Hampshire: Concord, New Hampshire Dept. Resources and Econ. Devel., p. 9

4. Feldspar-quartz-ferrohastingsite porphyry with feldspar phenocrysts

5. Gray, white to pink phenocrysts

7. Medium-grained; unit forms part of huge cauldron-subsidence structure

9. In steep intrusive contact with Moat Volcanics, Mount Osceola Granite, and Conway Granite (all of White Mountain Plutonic-Volcanic Series), but age interrelations not known

10. Type area: Mount Carrigain, Crawford Notch quadrangle, Grafton County, N.H.

Carroll Gneiss Member (James Run Formation)

1. Cambrian(?)

2. Maryland (NC)

3. Crowley, W. P., 1976, The geology of the crystalline rocks near Baltimore and its bearing on the evolution of the eastern Maryland Piedmont: Maryland Geol. Survey Rept. Inv. 27, p. 13-15

4. Biotite-quartz-plagioclase gneiss

7. Fine- to medium-grained

9. Overlies(?) or in thrust-fault contact with Hollofield Layered Ultramafite (Baltimore Mafic Complex) in E-W anticline; interfingers with Druid Hill Amphibolite Member (James Run Formation); underlies Relay Gneiss Member (James Run Formation) or Jones Falls Schist in NE-SW syncline

10. Type locality: Outcrops along unnamed tributary that flows through $W$ end of Carroll Park into Gwynns Falls, Baltimore City, Baltimore County, Md.

Cascade Quartzite (Deep Lake Group)

1. Early Proterozoic

2. Wyoming (SE)

3. Karlstrom, K. E., and Houston, R. S., 1979, Stratigraphy and uranium potential of Early Proterozoic metasedimentary rocks in the Medicine Bow Mountains, Wyoming: Wyoming Geol.

Survey Rept. Inv. 13, p. 16-19, 43-44

4. Quartzite, quartzarenite with black chert pebbles, pebble arkose

6. $1,450 \mathrm{~m}$

7. Crossbedded, resistant, with extensive outcrops; fluvial deposits

9. Overlies Campbell Lake Formation (with gradational contact at type section), or overlies Lindsey Quartzite; unconformably underlies Vagner Formation 
10. Type section: NW1/4 sec. 4, T. 16 N., R. 80 W., Medicine Bow Mountains, Carbon County, Wyo. Named for exposures near Cascade Lake, sec. 35, T. 17 N., R. 80 W.

Cave Branch Bed (Newman Limestone)

1. Late Mississippian

2. Kentucky (EC)

3. Dever, G. R., Jr., 1980, Stratigraphic relationships in the lower and middle Newman Limestone (Mississippian), eastcentral and northeastern Kentucky: Kentucky Geol. Survey, ser. 11, Thesis Ser. 1, p. 44-45, 48-49

4. Shale

5. Dark-green to greenish-gray

6. $0.75 \mathrm{~m}$, range $0.15-1.15 \mathrm{~m}$

7. Platy to bladed, clayey, contains abundant detrital quartz (silt to very fine sand)

9. Overlies informal Paoli-Beaver Bend Limestone member (at type section) or St. Louis Limestone Member; underlies informal Reelsville-Beech Creek Limestone member

10. Type section: S side of valley of Cave Branch in roadcut along Kentucky Highway $1274,0.5 \mathrm{~km} \mathrm{~S}$ of Licking River, Menifee County, Ky. Named for Cave Branch, a tributary of Licking River, NE Menifee and NW Morgan Counties.

\section{Cave Mountain Formation}

1. Triassic

2. Washington (NC)

3. Rinehart, C. D., and Fox, K. F., Jr., 1976, Bedrock geology of the Conconully quadrangle, Okanogan County, Washington: U.S. Geol. Survey Bull. 1402, p. 9-16

4. Carbonate-rich metasedimentary and metavolcanic rocks

5. Dark-gray, white to yellowish-gray

6. $1,300 \mathrm{~m}$

7. Thinly laminated to massive, fine- to coarse-grained; marine (slate and metalimestone member contains fossils); overturned folds

8. Informal members metalimestone, metasiltstone, metadolomite and metalimestone, slate and metalimestone, and basaltic metavolcanic members

9. Overlies, with probable unconformity, Anarchist Group; conformably underlies Triassic metamorphic complex of Conconully

10. Type locality: Exposures in dissected $S$ and $S E$ slopes of Cave Mountain, secs. $17,18,19$, and 20, T. 35 N., R. 26 E., Conconully quadrangle, Okanogan County, Wash.

Cedar Mountain Conglomerate Member (Bull Run Formation)

1. Late Triassic

2. Virginia (C)

3. Lindholm, R. C., 1979, Geologic history and stratigraphy of the Triassic-Jurassic Culpeper Basin, Virginia: Geol. Soc. America Bull. (pts. 1 and 2), v. 90, no. 11, p. 996 (pt. 1, summary); p. 1722-1723 (pt. 2, microfiche)

4. Greenstone pebble to boulder conglomerate

5. Red matrix (fresh); gray matrix (metamorphosed)

6. Range $240-1,400 \mathrm{~m}$

7. Clasts derived from Catoctin Formation

9. In normal-fault contact with older rocks of Blue Ridge along 


\footnotetext{
W border fault

10. Type locality: Exposures on Cedar Mountain, $14 \mathrm{~km}$ SW of Culpeper, Culpeper basin, Culpeper County, Va.
}

Cedar River Formation

1. Proterozoic

2. New York (NE)

3. McLelland, James, and Isachsen, Yngvar, 1980, Structural synthesis of the southern and central Adirondacks--a model for the Adirondacks as a whole and plate tectonics interpretations: Geol. Soc. America Bull. (pt. 2, microfiche), v. 91 , no. 2 , p. 231-233

4. Calcite marble with subordinate lenses of amphibolite, quartzite, and sillimanitic garnet-biotite gneiss

6. Range 100-300 m

7. Medium- to coarse-grained

9. Overlies basal quartzofeldspathic gneiss; underlies Lake Durant Formation; grades into Sacandaga Formation to SE

10. Type locality: Small gorge along Cedar River, SSE of Sugarloaf Mountain, SW Blue Mountain quadrangle, Hamilton County, N.Y.

Ceja Member (Santa Fe Formation)

1. Pliocene

2. New Mexico (C)

3. Kelley, V. C., 1977, Geology of Albuquerque Basin, New Mexico: New Mexico Bur. Mines and Mineral Resources Mem. 33, p. 18-20

4. Sandstone, conglomerate, mudstone

5. Buff, gray

6. $64.3 \mathrm{~m}$

7. Sandstone: thin- to medium-bedded, medium- to coarsegrained; conglomerate: thick-bedded, containing subrounded to angular pebbles to large boulders

9. Overlies informal middle red member, which is main body of Santa Fe Formation; underlies informal ortiz gravel (Pleistocene)

10. Type section: Exposure along $S$ side of El Rincon, a box canyon in W slope of Ceja Mesa, $19 \mathrm{~km} \mathrm{~W}$ of Albuquerque, NE1/4SE1/4 sec. 19, T. 10 N., R. 1 E., Bernal1llo County, N. Mex.

Cejita Member (Tesuque Formation)

1. Miocene, middle

2. New Mexico (NC)

3. Manley, Kim, 1977, Geologic map of the northeastern part of the Espanola Basin, New Mexico: U.S. Geol. Survey Misc. Field Studies Map MF-877

4. Conglomerate with interbedded sand

5. Grayish-brown

6. Range $1.5->140 \mathrm{~m}$

7. Well-sorted, coarse conglomerate, coarse- to fine-grained sand

9. Overlies lower Miocene unnamed eollan sand of Santa Fe Group; interfingers to SE with main part of Tesuque Formation (Santa Fe Group); locally unconformably underlies late Pliocene(?) surface gravels

10. Type section: Location of clast count $\mathrm{Cj} 12, \mathrm{~T}, 22$ N., 
R. 10 E., unsurveyed land grant, long $105^{\circ} 53^{\prime} 19^{\prime \prime}$ W., lat $3^{\circ} 08^{\prime} 18^{\prime \prime}$ N., Trampas quadrangle, Rio Arriba County, N. Mex. Named for exposures underlying and $S$ of Mesa de la Cejita.

\section{Charcoal Ovens Tuff}
1. Oligocene
2. Nevada (EC)
3. Hose, R. K., and Blake, M. C., Jr., 1976, Geology and mineral resources of White Pine County, Nevada--Pt. 1, Geol-
4. Tuff
6. $130 \mathrm{~m}$
7. Crystal-rich ash-flow, three cooling units; contains visible crystals of honey-yellow sphene
9. Overlies Sheep Pass Formation or Permian strata; underlies Windous Butte Formation
10. Type section: Quarry, SW1/4NW1/4 sec. 36, T. $14 \mathrm{~N}$. , R. 63 E., $300-450 \mathrm{~m} \mathrm{SW}$ of ovens in Ward Charcoal Ovens State Park, E side of southern part of Egan Range, White Pine County, Nev.

Chattahoochee Palisades Quartzite (Sandy Springs Group)
1. Precambrian, late(?) and (or) Paleozoic, early(?)
2. Georgia (NW)
3. Higgins, M. W., and McConnell, K. I., 1978, The Sandy Springs Group and related rocks in the Georgia Piedmont-- nomenclature and stratigraphy: U.S. Geol. Survey Bull. 1457-A, p. A103 (Also published in: Georgia Geol. Survey Bul1. 93, p. 52-53, 1978)
4. Quartzite interlayered with feldspathic quartzite and musco- vite schist
5. White, yellowish, bluish
6. $100 \mathrm{~m}$
7. Sugary to vitreous, massive, cliff-forming
9. Overlies in sharp contact (unconformably?) Powers Ferry Formation; gradationally underlies Factory Shoals Formation
10. Type area: Palisades of Chattahoochee River in Chatta- hoochee Palisades State Park, Sandy Springs quadrangle, Fulton County, Ga.

\section{Chilikadrotna Greenstone}
1. Late Silurian
2. Alaska (C)
3. Bundtzen, T. K., Gilbert, W. G., and Blodgett, R. B., 1979, The Chilikadrotna Greenstone, an Upper Silurian metavolcanic sequence in the central Lake Clark quadrangle, Alaska: Alaska Div. Geol. and Geophys. Surveys Geol. Rept. 61, p. $31-35$
4. Metamorphosed basalt (greenstone), hematite-rich basalt, and andesite, with interbedded limestone lenses and volcan- iclastic sedimentary rocks
5. Olive-gray to dark-green, weathers brown to maroon
7. Greenstone massive, ridge-forming; limestone fossiliferous
9. In probable high-angle fault contact on all sides with Upper Jurassic sedimentary and volcanic rocks
10. Type area: Upper Chilikadrotna River area, Lake Clark [C-4, C-5] quadrangle, Alaska. 


\section{Chill Lakes Till}

1. Holocene

2. Wyoming (NC)

3. Nelson, R. S., 1977, Glacial deposits of the Lake Angeline quadrangle, Bighorn Mountains, Wyoming: Earth Sci. Bull., v. 10 , no. 1 , p. 18

4. Cobble and boulder till in sand matrix

5. Pinkish-gray, weathers light gray

6. $6 \mathrm{~m}$

7. Loose, bouldery; end and ground moraines

9. Overlies informal Lake Lame Deer till; underlies Lake Angeline Till

10. Type locality: Moraine surrounding Chill Lakes, secs. 33 and 34, T. 50 N., R. 85 W., Bighorn Mountains, Johnson County, Wyo.

\section{Chisum Quarry Member (McCully Formation)}

1. Middle Pennsylvanian (Morrowan)

2. Oklahoma (EC)

3. Sutherland, P. K., and Henry, T. W., 1977, Carbonate platform facies and new stratigraphic nomenclature of the Morrowan Series (Lower and Middle Pennsylvanian), northeastern Oklahoma: Geol. Soc. America Bull., v. 88, no. 3, p. 433-434

4. Limestone interbedded with minor shale

5. Weathers reddish brown

6. $\quad 6.6 \mathrm{~m}$, range $1.5-11 \mathrm{~m}$

7. Grainstone and packstone, fossiliferous

9. Unconformably overlies Sausbee Formation; conformably underlies and interfingers with informal shale "A" member (McCully Formation)

10. Type section: Measured Section 1, W bluff of Arkansas River, 9 to $183 \mathrm{~m} \mathrm{~S}$ from $W$ end of Webbers Falls Lock and Dam, SW1/4SW1/4SE1/4 sec. 34, T. 13 N., R. 20 E., and Measured Section 3, $0.5 \mathrm{~km} \mathrm{NW}$ of MS 1 along river bluff, S1/2NW1/4SW1/4 sec. 34, T. 13 N., R. 20 E., Muskogee County, Okla.

\section{Ciniza Lake Beds (Monitor Butte Member of Chinle Formation)}

1. Late Triassic

2. New Mexico (NW)

3. Ash, S. R., 1978, Stratigraphy of the Ciniza Lake Beds and related strata, Chap. 1 in Ash, S. R., ed., Geology, paleontology, and paleoecology of a Late Triassic lake, western New Mexico: Brigham Young Univ. Geology Studies, v. 25, pt. 2 , p. $1-14$

4. Shale, mudstone

5. Gray, greenish-gray

6. $2.2 \mathrm{~m}$

7. Shale: fissile but without regular bedding, fossiliferous; mudstone: basal thin layer, structureless

9. Entirely within Monitor Butte Member: overlies flat-lying conglomerate or steeply dipping beds; gradationally underlies mudstone of main body

10. Type section: Locality FW6 in Eastern Wash, $490 \mathrm{~m} \mathrm{E}$ of New Mexico Highway 400 and $2.4 \mathrm{~km} \mathrm{~S}$ of Fort Wingate Post office, Zuni Mountains, McKinley County, N. Mex. Named for Ciniza Station on Santa Fe Railroad, $11 \mathrm{~km}$ NE of Fort Wingate. 
Circle Park Till

1. Pleistocene

2. Wyoming (NC)

3. Nelson, R. S., 1977, Glacial deposits of the Lake Angeline quadrangle, Bighorn Mountains, Wyoming: Earth Sci. Bull., v. 10 , no. 1 , p. 16

4. Cobble and boulder till in sand matrix

5. Light-gray, weathers light yellowish brown

6. $90 \mathrm{~m}$

7. Compact; terminal and ground moraines

9. Overlies Precambrian crystalline complex; underlies Sherd Lake Till

10. Type locality: Moraine $W$ of Circle Park Campground, SW1/4 sec. 20, T. 50 N., R. 84 W., Bighorn Mountains, Hunter Mesa quadrangle, Johnson County, Wyo.

Claremont Manor Member (Eastover Formation)

1. Miocene, late (Tortonian)

2. Virginia (SE), Maryland

3. Ward, L. W., and Blackwelder, B. W., 1980, Stratigraphic revision of upper Miocene and lower Pliocene beds of the Chesapeake Group, middle Atlantic Coastal Plain: U.S. Geol. Survey Bull. 1482-D, p. D12-D19

4. Silty and clayey sand, clay

5. Greenish-gray, weathers tan

6. $9 \mathrm{~m}$, range $9 \mathrm{-}-24 \mathrm{~m}$

7. Poorly sorted, coarse- to fine-grained, beds fining upward

9. Unconformably overlies St. Marys Formation or, to S, progressively older sediments; unconformably underlies Cobham Bay Member (Eastover Formation)

10. Type section: Exposures $1.3 \mathrm{~km}$ below mouth of Sunken Meadow Creek, $R$ bank of James River, Surry County, Va. Named for exposures along James River below Upper Chippokes Creek near Claremont Manor.

Cleofas Andesite

1. Eocene, late

2. New Mexico (SC)

3. Seager, W. R., Kottlowski, F. E., and Hawley, J. W., 1976, Geology of Doha Ana Mountains, New Mexico: New Mexico Bur. Mines and Mineral Resources Circ. 147, p. 14-15

4. Andesite porphyry

5. Tan, purple

7. Massive, fine-grained

9. Probably intrusive into Palm Park Formation; unconformably underlies Oligocene volcanic rocks (Doha Ana Rhyolite or unnamed younger cauldron fill of Doha Ana cauldron)

10. Type locality: Exposures near Cleofas well in Cleofas Canyon, SE1/4NE1/4 sec. 22, T. 21 S., R. 1 E., Dona Ana Mountains, Dona Ana County, N. Mex.

\section{Coal Canyon Formation}

1. Paleocene and Eocene(?)

2. California (SC)

3. Yerkes, R. F., and Campbell, R. H., 1979, Stratigraphic nomenclature of the central Santa Monica Mountains, Los Angeles County, California: U.S. Geol. Survey Bull. 1457-E, p. E8-E9 
4. Sandstone, pebbly sandstone, pebble conglomerate, siltstone with pods of algal limestone

6. $335 \mathrm{~m}$; range $335-450 \mathrm{~m}$

7. Cliff-forming, fossiliferous

9. Disconformably(?) overlies Tuna Canyon Formation or, locally, conformably overlies intervening Simi(?) Conglomerate; underlies Llajas(?) Formation

10. Type locality: Carbon (formerly Coal) Canyon, S1/2 sec. 22 and sec. 27, T. 1 S., R. 17 W., Santa Monica Mountains, SE Malibu Beach quadrangle, Los Angeles County, Calif.

Cobham Bay Nember (Eastover Formation)

1. Miocene, late (Tortonian)

2. Virginia (SE), Maryland, North Carolina

3. Ward, L. W., and Blackwelder, B. W., 1980, Stratigraphic revision of upper Miocene and lower Pliocene beds of the Chesapeake Group, middle Atlantic Coastal Plain: U.S. Geol. Survey Bull. 1482-D, p. D19-D28

4. Shelly sand

5. Tan

6. $\quad 3.7 \mathrm{~m}$, range $1-12 \mathrm{~m}$

7. Well-sorted, fine-grained, fossiliferous

9. Unconformably overlies Claremont Manor Member (Eastover Formation); unconformably underlies Sunken Meadow Member (Yorktown Formation)

10. Type section: Exposures $0.8 \mathrm{~km}$ below Cobham Wharf, $\mathrm{R}$ bank of James River, Surry County, Va. Named for exposures along James River at Cobham Bay.

Cold Creek Member (Topanga Canyon Formation)

1. Miocene, middle

2. California (SC)

3. Yerkes, R. F., and Campbell, R. H., 1979, Stratigraphic nomenclature of the central Santa Monica Mountains, Los Angeles County, California: U.S. Geol. Survey Bull. 1457-E, p. E 17

4. Sandstone

6. $707 \mathrm{~m}$

7. Medium-grained, bedded, silty to pebbly, fossiliferous, marine

9. Conformably overlies Fernwood Member (Topanga Canyon Formation); unconformably underlies Conejo Volcanics (Topanga Group) or, locally, Calabasas Formation (Topanga Group)

10. Type locality: Cold Creek-0ld Topanga Canyon area, SW1/4 sec. 35, T. 1 N., R. 17 W., Santa Monica Mountains, NE corner Malibu Beach quadrangle, Los Angeles County, Calif.

Cold Spring Gneiss

1. [Ordovician(?) or Silurian(?)]

2. Maryland (NC)

3. Crowley, W. P., 1976, The geology of the crystalline rocks near Baltimore and its bearing on the evolution of the eastern Maryland Piedmont: Maryland Geol. Survey Rept. Inv. 27, p. 13,15

4. Biotite-muscovite-quartz-feldspar gneiss or schistose gneiss

9. Intrudes Hollofield Layered Ul tramafite and Mount Washington Amphibolite (Baltimore Mafic Complex) and Druid Hill Amphibolite Member (James Run Formation) 
10. Type locality: Outcrops in Cold Spring Park, along Eflowing tributary of Jones Falls, Baltimore City, Baltimore County, Md.

Coleman River Formation (Coweeta Group)

1. Precambrian, late(?) [Late Proterozoic(?)]

2. Georgia (NC), North Carolina

3. Hatcher, R. D., Jr., 1979, The Coweeta Group and Coweeta syncline--major features of the North Carolina-Georgia Blue Ridge: Southeastern Geology, v. 21, no. 1, p. 21-23

4. Metasandstone, metaarkose, and quartz-feldspar gneiss with interlayers of pelitic schist

7. Medium-grained, foliated, metasandstone thinly laminated or "pinstriped"

9. Overlies Persimmon Creek Formation; underlies Ridgepole Mountain Formation

10. Type area: Exposures along headwaters of Coleman River, Dillard quadrangle, Rabun County, Ga.

\section{Combs Canyon Dolomite Member (Hanson Creek Formation)}

1. Silurian

2. Nevada (C)

3. Ross, R. J., Jr., Nolan, T. B., and Harris, A. G., 1979, The Upper Ordovician and Silurian Hanson Creek Formation of central Nevada: U.S. Geol. Survey Prof. Paper 1126-C, p. C5

4. Dolomite with conglomerate and chert beds

5. Dark-gray

7. Fossiliferous (pentamerid brachiopods); all outcrops of Hanson Formation are tectonically disturbed

9. Conformably overlies light-gray dolomite of middle (limestone and dolomite) member of Hanson Creek Formation; conformably underlies, or in thrust-fault contact with, Lone Mountain Dolomite

10. Type locality: S side of Combs Canyon, NE1/4 sec. 31 , T. 18 N., R. 52 E., Bellevue Peak quadrangle, Eureka County, Nev.

Comfort Member (Castle Hayne Formation)

1. Eocene, middle (Claibornian)

2. North Carolina (EC)

3. Ward, L. W., Lawrence, D. R., and Blackwelder, B. W., 1978, Stratigraphic revision of the middle Eocene, Oligocene, and lower Miocene--Atlantic Coastal Plain of North Carolina: U.S. Geol. Survey Bull. 1457-F, p. F8-F9

4. Calcirudite and calcarenite (limestone) with minor quartz, glauconite, and phosphate

5. Gray to cream-colored

6. $2 \mathrm{~m}$, range $2-10 \mathrm{~m}$

7. Fossiliferous

9. Unconformably overlies New Hanover Member (Castle Hayne Formation); conformably underlies Spring Garden Member (Castle Hayne Formation), or unconformably underlies Duplin Formation or River Bend Formation

10. Type locality: N. C. Lime Excavating Co. quarry, $6.4 \mathrm{~km} \mathrm{~W}$ of Comfort, just $\mathrm{N}$ of North Carolina Route 41 , Jones County, N.C. 


\section{Conant Creek Tuff}

1. Pliocene

2. Wyoming (NW), Idaho

3. Christiansen, R. L., and Love, J. D., 1978, The Pliocene Conant Creek Tuff in the northern part of the Teton Range and Jackson Hole, Wyoming: U.S. Geol. Survey Bull. 1435-C, p. $\mathrm{C} 1-\mathrm{C} 9$

4. Rhyolitic ash-flow tuff

5. Gray to purplish-gray

6. $125 \mathrm{~m}$, range $<1-125 \mathrm{~m}$

7. Welded, sparse phenocrysts

9. Unconformably overlies Hominy Peak Formation (at type section), or Teewinot or Bivouac Formation; unconformably underlies Huckleberry Ridge Tuff (Yellowstone Group)

10. Type section: Exposure on $N$ side of South Boone Creek where steep-sided tributary enters main creek, NE1/4SW1/4 sec. 5, T. 47 N., R. 117 W., Grassy Lake Reservoir quadrangle, Teton County, Wyo. Named for nearby Conant Creek.

\section{Condrey Mountain Schist}

1. Late Jurassic

2. California (NW), Oregon

3. Hotz, P. E., 1979, Regional metamorphism in the Condrey Mountain quadrangle, north-central Klamath Mountains, California: U.S. Geol. Survey Prof. Paper 1086, p. 2-9

4. Quartz-muscovite schist, actinolite-chlorite schist

5. Gray to brownish-gray

7. Fine-grained, alternating light and dark laminae

9. Bordered on $E$ and $W$ by Paleozolc and Triassic(?) unnamed rocks of amphibolite metamorphic facies structurally overlying and thrust over Condrey Mountain Schist

10. Type locality: Exposures on $S$ side of Klamath River between Dona and McKinney Creeks, secs. 8 and 9, T. 46 N., R. 9 W., NC Klamath Mountains, Siskiyou County, Calif. Named for Condrey Mountain, sec. 11, T. 47 N., R. 10 W.

\section{Congress Canyon Formation (Star Peak Group)}

1. Middle and Late Triassic (Ladinian and Karnian)

2. Nevada (NW)

3. Nichols, K. M., and Silberling, N. J., 1977, Stratigraphy and depositional history of the Star Peak Group (Triassic), northwestern Nevada: Geol. Soc. America Spec. Paper 178,p. 51-54

4. Limestone

5. Gray

6. $120 \mathrm{~m}$, range $120-300 \mathrm{~m}$

7. Coarse-grained, massive, cliff-forming, platform-margin deposits

9. Overlies unnamed upper member of Prida Formation (Star Peak Group); underlies sugary secondary dolomite under Panther Canyon or Smelser Pass Members of Augusta Mountain Formation (Star Peak Group)

10. Type section: Head of Congress Canyon, W1/2 sec. 16, T. 30 N., R. 34 E., N Humboldt Range, Pershing County, Nev.

Conover Bentonite Bed (Rivoli Member of Dunleith Formation)/(Loves Park Member of Dunleith Formation, in Illinois only)

1. Middle Ordovician 
2. Iowa (NE), Illinois

3. Willman, H. B., and Kolata, D. R., 1978, The Platteville and Galena Groups in northern Illinois: Illinois Geol. Survey Circ. 502, p. 49

4. Bentonite

6. $0.025 \mathrm{~m}$

9. In type section, topmost unit of Rivoli Member; underlies Sherwood Member (Dunleith Formation)

10. Engineers 01d Cut Section, stream diversion channel, $2.4 \mathrm{~km}$ W of Decorah, SE1/4NE1/4 sec. 18, T. 98 N., R. 8 W., Winneshiek County, Iowa. Named for town of Conover, $11.2 \mathrm{~km} \mathrm{SW}$ of type section.

Coon Valley Member (Jordan Formation)

1. Early Ordovician

2. Wisconsin (SW), Iowa, Minnesota

3. Odom, I. E., and Ostrom, M. E., 1978, Lithostratigraphy, petrology, sedimentology, and depositional environments of the Jordan Formation near Madison, Wisconsin: Soc. Econ. Paleontologists and Mineralogists, Great Lakes Sec., 8 th Ann. Mtg., Guidebook 3, p. 26-27, 31-34, 43

4. Dolomitic sandstone, sandy dolostone, and sandstone with interbedded shale, chert, oolites, and algal structures

6. $11 \mathrm{~m}$

7. Fine- to medium-grained, poorly sorted

9. Overlies Van Oser Member or Sunset Point Member (Jordan Formation); underlies Oneota Formation

10. Type section: $S$ side of U.S. Highway $14,3.2 \mathrm{~km}$ W of town of Coon Valley, NW1/4NE1/4 sec. 11, T. 14 N., R. 6 W., Vernon County, Wis.

\section{Copper Basin Formation}

1. Miocene, early

2. California (SE), Arizona

3. Davis, G. A., and others, 1980, Mylonitization and detachment faulting in the Whipple-Buckskin-Rawhide Mountains terrane, southeastern California and western Arizona: Geol. Soc. America Mem. 153, p. 95

4. Sandstone, conglomerate, and siltstone with interbedded andesitic(?) volcanic rocks

5. Red

6. $>750 \mathrm{~m}$

7. Cross-bedding, ripple marks, mudcracks; upper unit in allochthonous upper-plate assemblage separated from lowerplate assemblage by subhorizontal detachment fault

9. Unconformably overlies Gene Canyon Formation on $E$ and $S$ margins of Whipple Mountains, but overlies upper-plate crystalline basement rocks in $C$ part of mountains; unconformably underlies Osborne Wash Formation

10. Type section: Not stated. Probably named for Copper Basin in EC Whipple Mountains, San Bernardino County, Calif.

Copper Creek Conglomerate (Libby Creek Group)

1. Early Proterozoic

2. Wyoming (SC)

3. Divis, A. F., 1976, Geology and geochemistry of Sierra Madre Range, Wyoming: Colorado School Mines Quart., v. 71, no. 3, p. $26-27$ 
4. Conglomerate composed of granitic clasts in schist matrix

6. Range $75-100 \mathrm{~m}$

7. Angular to subrounded clasts widely dispersed through finegrained matrix

9. Conformably overlies Bridger Peak Quartzite; conformably underlies Quartzite Peak Quartzite

10. Type area: Outcrops at confluence of North Fork of Miner and Copper Creeks at boundary of secs. 27 and $28, T .14 \mathrm{~N}$., R. 84 W., Carbon County, Wyo.

\section{Copper Lake Formation}

1. Paleocene(?) and Eocene

2. Alaska (C)

3. Detterman, R. L., and Reed, B. L., 1980, Stratigraphy, structure, and economic geology of the Iliamna quadrangle, Alaska: U.S. Geol. Survey Bull. 1368-B, p. B45-B48

4. Conglomerate, sandstone, siltstone

5. Gray

6. Lower conglomerate member: $91 \mathrm{~m}$; sandstone and siltstone member: $503 \mathrm{~m}$; upper conglomerate member: $975 \mathrm{~m}$

8. Informal lower conglomerate member, sandstone and siltstone member, and upper conglomerate member

9. Nonconformably overlies Middle Jurassic quartz diorite pluton or unconformably overlies Kakhonak Complex; unconformably underlies Tertiary volcanic rocks

10. Type section: Composite of type sections of members. Lower conglomerate member: $E$ end of ridge $2.5 \mathrm{~km} \mathrm{~S} .45^{\circ} \mathrm{E}$. of outlet of Upper Copper Lake; sandstone and siltstone member: E slope of peak $2432,1.6 \mathrm{~km} \mathrm{~S}$ of $\mathrm{W}$ end of Boot Lake; upper conglomerate member: ravine cutting $\mathrm{E}$ face of ridge between Fog and Kakhonak Lakes; all between Upper Copper Lake and Sid Larson Bay, SE of Lake Iliamna, Iliamna quadrangle, Alaska Peninsula, Alaska.

\section{Copperopolis Latite (Tintic Mountain Volcanic Group)}

1. Oligocene, middle

2. $\operatorname{Utah}(\mathrm{C})$

3. Morris, H. T., and Lovering, T. S., 1979, General geology and mines of the East Tintic mining district, Utah and Juab Counties, Utah: U.S. Geol. Survey Prof. Paper 1024, p. $36-38$

4. Latite agglomerate and spatter breccia, tuff, and flow

5. Lower member: dark-green; middle member: gray-green; upper member: black, reddish-brown

6. $>120 \mathrm{~m}$

7. Lower member: coarse-grained, massive; middle member: fine- to medium-grained, layered; upper member: finegrained

8. Informal lower agglomerate and spatter breccia member, middle tuff member, and upper flow member

9. Unconformably overlies Packard Quartz Latite; unconformably underlies Latite Ridge Latite (Tintic Mountain Volcanic Group)

10. Type locality: Exposures in Copperopolis Canyon, secs. 31, 32, and 33, T. 11 S., R. 2 W., WC part of East Tintic Mountains, $16 \mathrm{~km} \mathrm{SW}$ of East Tintic mining district, Juab County, Utah. 


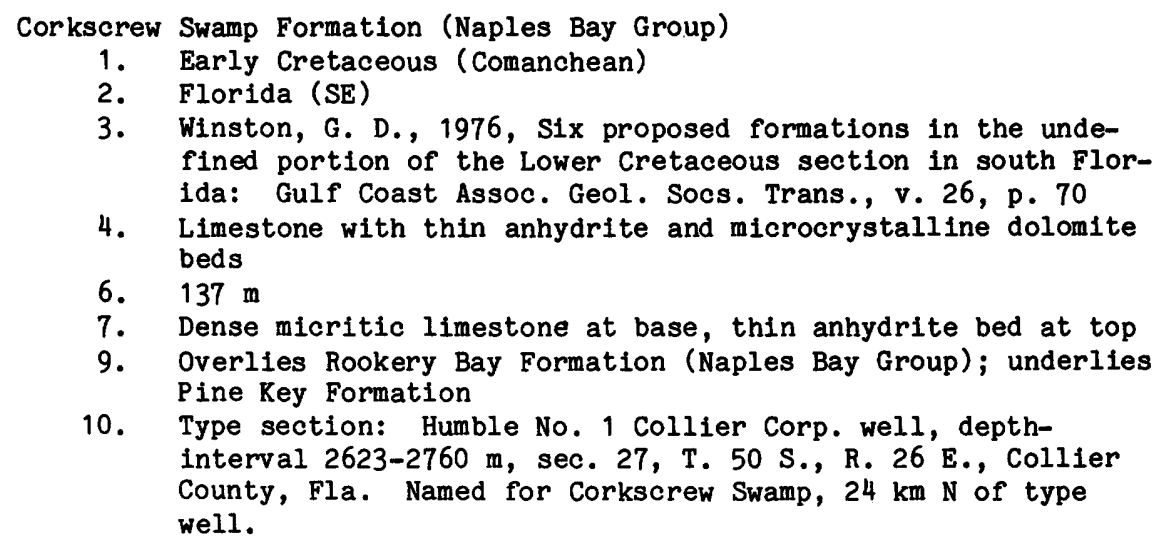

\section{Cortina Formation}

1. Late Cretaceous

2. California (NW)

3. Ingersol1, R. V., Rich, E. I., and Dickinson, W. R., 1977, Field guide--Great Valley Sequence, Sacramento Valley:

Geol. Soc. America, Cordilleran Sec., Ann. Mtg., [Guidebook $8]$, p. $28,33-35$

4. Sandstone, siltstone, mudstone

5. Olive, gray

6. $2,900 \mathrm{~m}$

7. Thin- to thick-bedded; coarse-grained; mixed plutonic and volcanic detritus deposited in deep-marine trough

8. Venado Sandstone Member at base; Sites Sandstone Member

9. Conformably overlies or intertongues with Boxer Formation; underlies Rumsey Formation

10. Type section: Exposures on Cortina Ridge, Wilbur Springs quadrangle, Colusa County, Calif.

\section{Cottonwood Bay Greenstone}

1. Late Triassic

2. Alaska (C)

3. Detterman, R. L., and Reed, B. L., 1980, Stratigraphy, structure, and economic geology of the Iliamna quadrangle, Alaska: U.S. Geol. Survey Bull. 1368-B, p. B9-B11

4. Mafic volcanic rocks altered to hornfels and chloritic greenschist

5. Dark-green, gray

6. $>600 \mathrm{~m}$

7. Original porphyritic texture mostly altered to hornfelsic and granoblastic

9. Locally so intensely altered as to be part of Kakhonak Complex; locally cannot be distinguished from Talkeetna Formation; underlies Bruin Limestone Member (Kamishak Formation)

10. Type locality: Exposures on S shore near head of Cottonwood Bay, Cook Inlet, Iliamna quadrangle, Alaska Peninsula, Alaska.

2. Virginia (SW) 
3. Miller, R. L., and Meissner, C. R., Jr., 1977, Geologic map of the Big A Mountain quadrangle, Buchanan and Russell Counties, Virginia: U.S. Geol. Survey Geol. Quad. Map GQ-1350

4. Sand stone

5. Light-gray

6. $24 \mathrm{~m}$, range $<1-49 \mathrm{~m}$

7. Medium- to coarse-grained, conglomeratic, thick-bedded, cross-bedded, wedges out in many places

9. Overlies Tiller coal bed; underlies Jawbone coal bed

10. Type locality: Exposure in bluff and roadcut of Virginia Highway 80 directly beneath Council Elementary School. Named for town of Council in NC part of Big A Mountain quadrangle, Buchanan County, Va.

Cove Mountain Member (Flagstaff Limestone)

1. Paleocene, late, and (or) Eocene, early

2. Utah (C)

3. Stanley, K. O., and Collinson, J. W., 1979, Depositional history of Paleocene-lower Eocene Flagstaff Limestone and coeval rocks, central Utah: Am. Assoc. Petroleum Geologists Bull., v. 63, no. 3, p. 316-318

4. Dolomicrite, mudstone, gypsum

5. White, pinkish-gray, yellowish-brown

6. $185 \mathrm{~m}$

7. Sparsely fossiliferous; represents low stand of Lake Flagstaff

8. Eight informal units, I through $P$

9. Overlies Ferron Mountain Member; underlies Musinia Peak Member

10. Type locality: S side of Cove Mountain, NW1/4 sec. 2, T. 19 S., R. 4 E., and SW1/4 sec. 35 , T. 18 S., R. 4 E., Wasatch Plateau, Sanpete County, Utah.

Cow Creek Conglomerate (Libby Creek Group)

1. Early Proterozoic

2. Wyoming (SC)

3. Divis, A. F., 1976, Geology and geochemistry of Sierra Madre Range, Wyoming: Colorado School Mines Quart., v. 71, no. 3, p. $22-26$

4. Conglomerate composed of granitic, mafic, and quartzite

clasts in quartzite to amphibolite matrix

6. $>300 \mathrm{~m}$

7. Coarse, well-rounded clasts, spheroids to severely stretched ellipsoids

9. Lithologically similar to Headquarters Schist (Libby Creek Group) in Medicine Bow Range; basal Formation in Libby Creek Group in Sierra Madre Range; overlies Green Mountain Formation with structural unconformity; conformably underlies Bridger Peak Quartzite (Libby Creek Group)

10. Type area: Outcrops on $S$ wall of Cow Creek valley, T. 14 N., R. 85 W., Sierra Madre Range, Carbon County, Wyo.

Coweeta Group

1. Precambrian, late(?) [Late Proterozoic(?)]

2. North Carolina (WC), Georgia

3. Hatcher, R. D., Jr., 1979, The Coweeta Group and Coweeta syncline--major features of the North Carolina-Georgia Blue Ridge: Southeastern Geology, v. 21, no. 1, p. 17-29 
4. Feldspar-quartz-biotite gneiss, metasandstone, quartzite, schist

6. Range 2,000-4,000 m

7. Occupies syncline resulting from polyphase deformation

8. Persimmon Creek Gneiss, Coleman River Formation, Ridgepole Mountain Formation

9. Overlies Tallulah Falls Formation; upper contact not observed (top eroded)

10. Type area: Upper reaches of Coweeta Creek in Coweeta Hydrologic Laboratory, S of Franklin, Macon County, N.C.

Cowen Member (Grand Detour Formation)

1. Middle Ordovician

2. Illinois (NC)

3. Willman, H. B., and Kolata, D. R., 1978, The Platteville and Galena Groups in northern Illinois: Illinois Geol. Survey Circ. 502, p. 30

4. Dolomite to shaly dolomite

6. $2.3 \mathrm{~m}$, range $1.8-5.4 \mathrm{~m}$

7. Thin- to medium-bedded

9. Overlies Mifflin Formation; underlies Stillman Member (Grand Detour Formation)

10. Type section: Brookville Northwest Section, quarry on $\mathbf{N}$ side of ravine $\mathrm{NE}$ of U.S. Highway 52 , NE1/4SE1/4NW1/4 sec. 21 , T. $24 \mathrm{~N}$., R. 7 E., Carroll County; $1.6 \mathrm{~km} \mathrm{NW}$ of Brookville, Ogle County, Ill. Named for Cowen School, 3.2 $\mathrm{km} \mathrm{SW}$ of type section.

Cow Hollow Bed (Laney Member of Green River Formation)

1. Eocene

2. Wyoming (SW)

3. Sullivan, Raymond, 1980, A stratigraphic evaluation of the Eocene rocks of southwestern Wyoming: Wyoming Geol. Survey Rept. Inv. 20, p. 30

4. Shale, marlstone, sandstone, siltstone

5. Buff-weathering

6. Range 9-15 m

7. Lacustrine deposits

9. On W margin of Green River Basin, overlies and intertongues with Whiskey Butte Bed (Bridger Formation); underlies main body of Bridger; merges with main body of Laney Member to $S$

10. Type locality: Exposures along Cow Hollow Creek, T. 21 N., R. 113 W., Cow Hollow quadrangle, Lincoln County, Wyo.

\section{Crater Flat Tuff}

1. Miocene

2. Nevada (SC)

3. Byers, F. M., Jr., and others, 1976, Volcanic suites and related cauldrons of Timber Mountain-Oasis Valley caldera complex, southern Nevada: U.S. Geol. Survey Prof. Paper 919, p. 10-11, 14-15

4. Tuff

5. Varicolored

6. $190 \mathrm{~m}$

7. Welded to nonwelded, devitrified, phenocrysts

8. Bullfrog and Prow Pass Members and local unnamed intercalated breccia, bedded tuff, and ash-flow tuff

9. Overlies Redrock Valley Tuff; underlies, to S, all construc- 
tional lavas of Wahmonie-Salyer volcanic center and rhyolite lavas of Calico Hills

10. Type locality: Exposed at $S E$ end of unnamed hogback at $S$ side of Crater Flat, Bare Mountain quadrangle, Nye County, Nev.

Craven Creek Bed (Laney Member of Green River Formation)

1. Eocene

2. Wyoming (SW)

3. Sullivan, Raymond, 1980, A stratigraphic evaluation of the Eocene rocks of southwestern Wyoming: Wyoming Geol. Survey Rept. Inv. 20, p. 30

4. Calcareous silty shale, laminated siltstone, sandstone

5. Buff

6. $36 \mathrm{~m}$

7. Lacustrine deposits

9. On $W$ margin of Green River Basin, overlies and intertongues with Desertion Point Member (Wasatch Formation, underlies and intertongues with Whiskey Butte Bed (Bridger Formation); merges with main body of Laney Member to $S$ and $E$

10. Type locality: Exposures along Craven Creek, $N$ of Hams Fork, T. 21 N., R. 114 W., Opal quadrangle, Lincoln County, Wyo.

Cross Member (Santee Limestone)

1. Eocene, middle (Claibornian)

2. South Carolina (C)

3. Ward, L. W., and others, 1979, Stratigraphic revision of Eocene, Oligocene and lower Miocene formations of South Carolina: South Carolina Geol. Survey Geol. Notes, v. 23, no. 1 , p. 8-9

4. Biomicrite (limestone)

5. Grayish-yellow

6. $1 \mathrm{~m}$, range $1-41 \mathrm{~m}$

7. Bryozoan-brachiopod-bivalve blomicrite, deeply burrowed

9. Unconformably overlies Moultrie Member (Santee Limestone); unconformably underlies Raysor Formation at type section, or Harleyville Member (Cooper Formation)

10. Type section: Section at Martin Marietta Co. Berkeley quarry, $2.4 \mathrm{~km} \mathrm{~S}$ of Route 6 and Route 59 intersection, Chicora 15' quadrangle, Berkeley County, S.C. Named for nearby town of Cross.

\section{Cross Creek Granite}

1. [Early Proterozoic]

2. Colorado (C)

3. Tweto, Ogden, and Lovering, T. S., 1977, Geology of the Minturn 15-minute quadrangle, Eagle and Summit Counties, Colorado: U.S. Geol. Survey Prof. Paper 956, p. 8-12

4. Granite to granodiorite, typically quartz monzonite

5. Gray to pinkish-gray

7. Coarse-grained, gneissic, porphyritic; batholith occupies area of $130 \mathrm{sq} \mathrm{km}$

9. Intrudes enclosing gneiss with concordant and gradational contacts; intermixed with closely related diorite and migmatite; unconformably underlies Sawatch Quartzite

10. Type area: Cross Creek, $N$ end of Sawatch Range, Minturn quadrangle, Eagle County, Colo. 


\section{Daguao Formation}

1. Early Cretaceous

2. Puerto Rico (EC)

3. M'Gonigle, J. W., 1977, The Río Abajo, Pitahaya, and Daguao Formations in eastern Puerto Rico: U.S. Geol. Survey Bull. 1435-B, p. B7-B9

4. Andesite breccia, lava, volcanic sandstone, and crystal tuff

5. Medium-gray to medium-dark-gray

6. $>1,000 \mathrm{~m}$

7. Massive breccia, cut by fine-grained and porphyritic lava dikes; lava flows; two hypabyssal intrusive bodies of breccia representing volcanic necks

9. Base not exposed; sharply or gradationally(?) underlies Figuera Lava; in intrusive contact with Tertiary(?) plutonic rocks

10. Type area: Exposures in housing excavations just $\mathrm{N}$ of town of Daguao at 46,000 N., 231,500 E.; Municipio de Naguabo, Naguabo quadrangle, P.R.

Dalmatia Member (Mahantango Formation)

1. Middle Devonian

2. Pennsylvania (C)

3. Faill, R. T., Hoskins, D. M., and Wells, R. B., 1978, Middle Devonian stratigraphy in central Pennsylvania--a revision: Pennsylvania Geol. Survey, 4 th ser., Gen. Geology Rept. 70, p. 11-14, 21-22

4. Shale, siltstone, sandstone

5. Olive-gray

6. $>67 \mathrm{~m}, 90 \mathrm{~m} \max$

7. Cyclic deposits, coarsening upward; sparsely fossiliferous

9. Overlies Turkey Ridge Member; underlies Fisher Ridge Member

10. Type section: $\mathrm{N}$ wall of third abandoned quarry, counting from $S$, along $E$ side of Penn Central Railroad, $3.2 \mathrm{~km} \mathrm{~S}$ of Dalmatia, Northumberland County, $\mathrm{Pa}$.

\section{Danielson Member (Vaqueros Formation)}

1. Miocene, early

2. California (SC)

3. Yerkes, R. F., and Campbell, R. H., 1979, Stratigraphic nomenclature of the central Santa Monica Mountains, Los Angeles County, California: U.S. Geol. Survey Bull. 1457-E, p. E12

4. Mudstone, siltstone

5. Grayish-black

7. Very fine grained, thin- to medium-bedded, fossiliferous, local biostromes

9. Overlies Sespe Formation; conformably underlies San Nicholas Member (Vaqueros Formation)

10. Type locality: Exposures on Danielson Ranch, Big Sycamore Canyon, Santa Monica Mountains, Newbury Park quadrangle, Ventura County, Calif. Reference locality: Exposures in upper Trancas Canyon, W Point Dume quadrangle, Los Angeles County.

Day Mountain Member (Seboomook Formation)

1. Early Devonian

2. Maine (WC)

3. Pankiwskyj, K. A., 1979, Bedrock geology of the Kingfield 
and Anson 15' quadrangles, Franklin and Somerset Counties, Maine: Maine Geol. Survey Geol. Map Series GM-7, 51 p.

4. Metasiltstone, metapelite, graywacke

5. Gray

6. $>1,000 \mathrm{~m}$

7. Rhythmically bedded

8. Granule metaconglomerate and metalimestone submembers

9. Gradationally overlies and intertongues with Temple Stream Member (Seboomook Formation)

10. Type locality: Exposures on ridge and slopes of Day Mountain, SW corner of Kingfield quadrangle, Franklin County, Maine.

Deer Lake Complex

1. Precambrian

2. Minnesota (NC)

3. Berkley, J. L., and Himmelberg, G. R., 1978, Cumulus mineralogy and petrology of the Deer Lake Complex, Itasca County, Minnesota: Minnesota Geol. Survey Rept. Inv. 20-A, p. A1A 18

4. Peridotite, clinopyroxenite, gabbro, diorite

6. $430 \mathrm{~m}$

7. Three layered sills, each intruded along upper contact of previous one; each magma injection fractionated into sequence of ultramafic to dioritic rocks

9. Conformably intrudes early Precambrian metabasalt and metasedimentary rocks; cut by middle Precambrian(?) gabbroic dikes

10. Type locality: NE-trending band $10 \mathrm{~km}$ long and $2.5 \mathrm{~km}$ wide in Tps. 61-62 N., Rs. 24-25 W., $4 \mathrm{~km} \mathrm{SW}$ of Deer Lake and 6.5 $\mathrm{km}$ NE of Bigfork, Itasca County, Minn.

Deicke Bentonite Bed (Castlewood Member of Spechts Ferry Formation)

1. Middle Ordovician

2. Missouri (EC), Illinois, Iowa, Wisconsin

3. Willman, H. B., and Kolata, D. R., 1978, The Platteville and Galena Groups in northern Illinois: Illinois Geol. Survey Circ. 502 , p. 43

4. Bentonite clay

5. Light-gray, alters pink

6. $0.13 \mathrm{~m}$

7. Altered locally to bed of hard monoclinic potash feldspar

9. Near or at base of Castlewood Member (Spechts Ferry Formation), which unconformably overlies Quimbys Mill Formation

10. Type section: Mincke Section, in $S$ bluff of Meramec River along St. Louis-San Francisco Railroad, $0.4 \mathrm{~km}$ NE of Mincke Siding, center E1/2SE1/4SE1/4 sec. 21, T. 44 N., R. 4 E., St. Louis County, Mo. Named for town of Deicke, $3.2 \mathrm{~km} \mathrm{SW}$ of type section.

Dell Tuff

1. Oligocene

2. Utah (WC)

3. Lindsey, D. A., 1979, Geologic map and cross-sections of Tertiary rocks in the Thomas Range and northern Drum Mountains, Juab County, Utah: U.S. Geol. Survey Misc. Inv. Ser. Map I-1176

4. Rhyolitic ash-flow tuff with crystals of quartz, sanidine, 


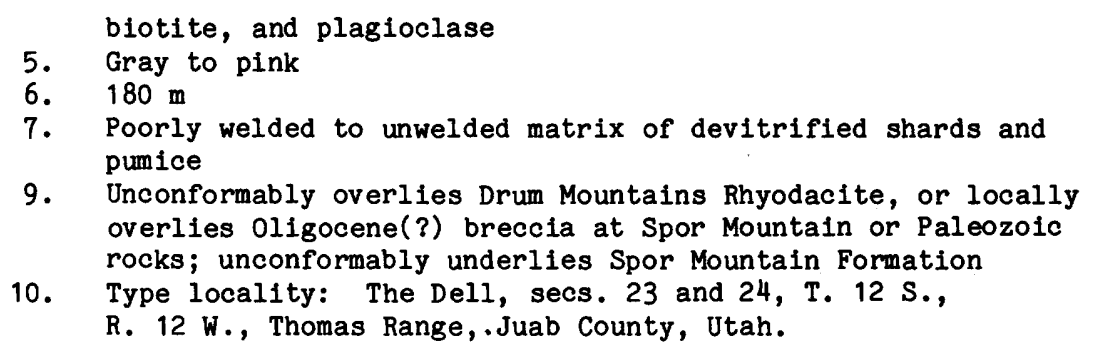

Del Norte Formation

1. Early Cretaceous

2. New Mexico (SC), Texas, Mexico

3. Strain, W. S., 1976, New formation names in the Cretaceous at Cerro de Cristo Rey, Dona Ana County, New Mexico, Appendix 2 in Lovejoy, E. M. P., Geology of Cerro de Cristo Rey uplift, Chihuahua and New Mexico: New Mexico Bur. Mines and Mineral Resources Mem. 31, p. 77-78

4. Shale interbedded with sandy limestone and sandstone

5. Gray, tan

6. $17.2 \mathrm{~m}$

7. Fossiliferous, nodular

8. Informal lower clay member and upper calcareous member (equivalent to informal Brick Plant and Refinery members of Strain, 1968)

9. Conformably overlies Finlay Formation; conformably underlies Smeltertown Formation

10. Type section: Outcrops $W$ of kilns at El Paso Brick Company plant, NW1/4SW1/4NW1/4 sec. 15, T. 29 S., R. 4 E., Smeltertown quadrangle, Dona Ana County, N. Mex. Named for Río Bravo del Norte, original name of Río Grande.

Denham Formation (Mille Lacs Group)

1. Precambrian, middle

2. Minnesota (C)

3. Morey, G. B., 1978, Lower and middle Precambrian stratigraphic nomenclature for east-central Minnesota: Minnesota Geol. Survey Rept. Inv. 21, p. 15-18

4. Heterogeneous sequence of arenitic quartz-rich rocks ranging from conglomerate to siltstone, with interbedded quartzite, dolomite, and metabasalt

5. Greenish-gray, reddish-gray

7. Layered

9. Unconformably overlies McGrath Gneiss; to W, underlies or grades laterally into Glen Township Formation (Mille Lacs Group), or unconformably underlies Animikie Group

10. Type locality: Exposures in abandoned river valley $1.6 \mathrm{~km}$ SE of village of Denham, SE1/4 sec. 25 and NE1/4 sec. 26, T. 45 N., R. 21 W., Pine County, Minn.

Desertion Point Tongue (Wasatch Formation)

1. Eocene

2. Wyoming (SW)

3. Sullivan, Raymond, 1980, A stratigraphic evaluation of the Eocene rocks of southwestern Wyoming: Wyoming Geol. Survey Rept. Inv. 20, p. 13-15

4. Siltstone and sandstone with interbeds of marlstone and 


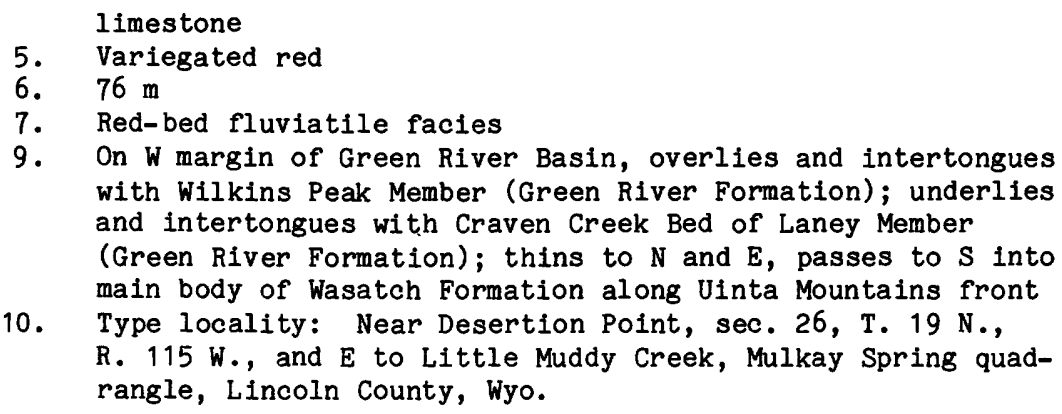

Desert Range Limestone Hember (Carrara Formation)

1. Middle Cambrian

2. Nevada (SE), California

3. Palmer, A. R., and Halley, R. B., 1979, Physical stratigraphy and trilobite biostratigraphy of the Carrara Formation (Lower and Middle Cambrian), southern Great Basin: U.S.

Geol. Survey Prof. Paper 1047, p. 20-21

4. Argillaceous limestone, with dolomitic partings

5. Black, orange

6. $20 \mathrm{~m}$, varies considerably and inconsistently

7. Thin-bedded, fossiliferous

9. Overlies Jangle Limestone Member (Carrara Formation); gradationally underlies Bonanza King Formation

10. Type locality: Exposures at Desert Range, about $64 \mathrm{~km} \mathrm{NW}$ of Las Vegas, Clark County, Nev.

\section{Devine Canyon Ash-flow Tuff}

1. Miocene, late

2. Oregon (EC)

3. Walker, G. W., 1979, Revisions to the Cenozoic stratigraphy of Harney Basin, southeastern Oregon: U.S. Geol. Survey Bull. 1475, p. 15-20

4. Tuff

5. Greenish-gray to light-gray

6. $30 \mathrm{~m}$

7. Densely to moderately welded, crystal-rich, vitric

9. Overlies unnamed middle(?) and upper Miocene volcaniclastic and sedimentary rocks which overlie Steens Basalt; conformably underlies unnamed tuffaceous sedimentary rocks which underlie Prater Creek Ash-flow Tuff; to NE, in Juntura Basin, underlies Drewsey Formation

10. Type locality: Exposures in Devine Canyon about $1 \mathrm{~km}$ NNE of its confluence with Poison Creek, along U.S. Highway 395, lat $43^{\circ} 44^{\prime} 05^{\prime \prime}$ N., long $119^{\circ}$ W., Harney County, Oreg.

\section{Diamond City Clay}

1. Pleistocene

2. North Carolina (EC)

3. Susman, K. R., and Heron, S. D., Jr., 1979, Evolution of a barrier island, Shackleford Banks, Carteret County, North Carolina: Geol. Soc. America Bull., (pt. 1), v. 90, no. 2, p. 207-209

4. Soft silty illite-rich clay interbedded with shell hash in sandy clay matrix

5. Gray 


\begin{abstract}
6. $6 \mathrm{~m}$
9. Disconformably overlies informal Core Creek sand (Pleistocene); unconformably underlies informal Outer Banks sand (Holocene)

10. Type locality: Drill hole SH-11, on E end of Shackleford Banks, Carteret County, N.C. Named for abandoned whaling village on this site.
\end{abstract}

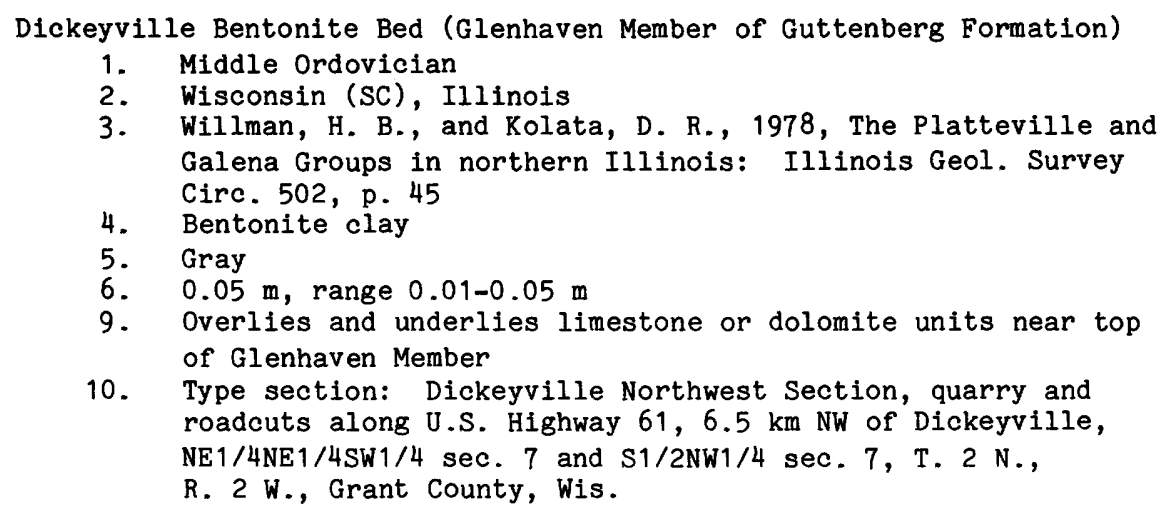

Dobys Bluff Tongue (Kosciusko Formation)

1. Eocene

2. Mississippi (EC)

3. Dockery, D. T., III, 1980, The invertebrate macropaleontology of the Clarke County, Mississippi, area: Mississippi Bur. Geology Bull. 122, p. 33-41

4. Sand, carbonaceous clay

5. Gray, weathers reddish brown

6. $6 \mathrm{~m}$

7. Lenticular, marine destructional shelf facies, fossiliferous

9. Overlies nonfossiliferous sand of Kosciusko Formation; unconformably underlies Archusa Marl Member (Cook Mountain Formation)

10. Type section: Exposure at Dobys Bluff, E side of Chickasawhay River $S$ of Quitman, NW1/4SW1/4NW1/4 sec. 18, T. $2 \mathrm{~N}$. , R. 16 E., Clarke County, Miss.

Domerie Member (Lakedale Drift)

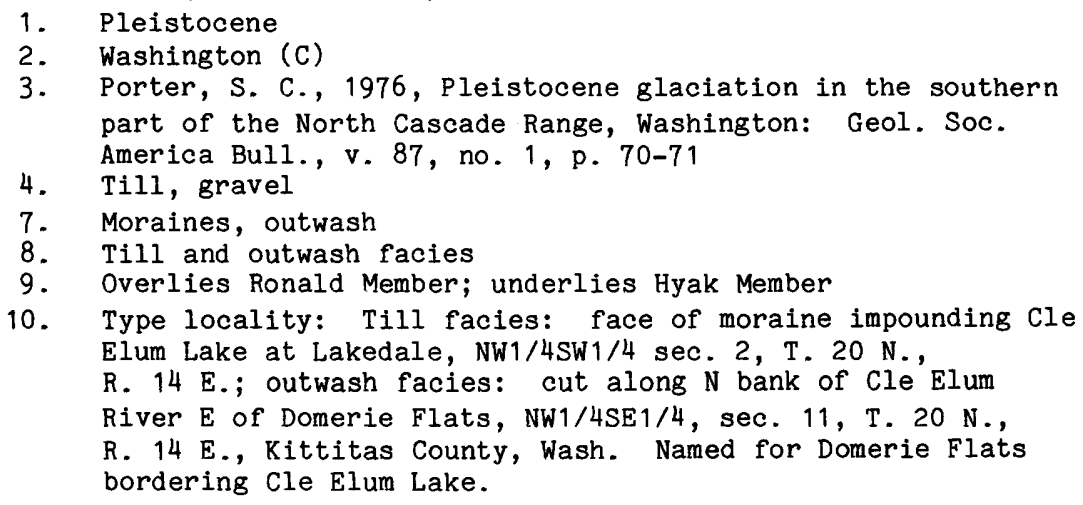




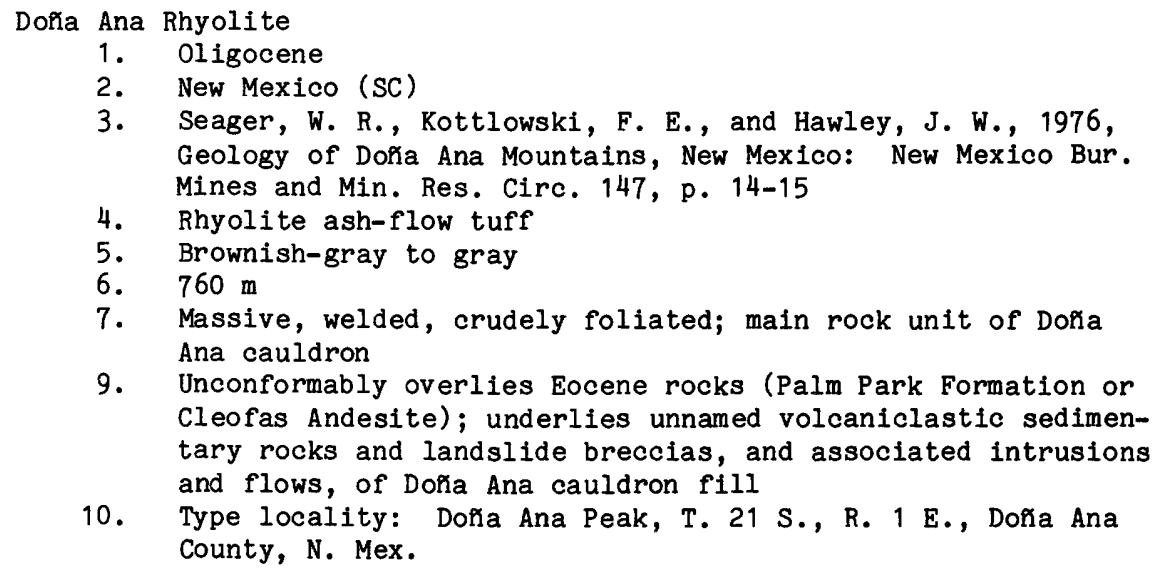

Doswell Formation

1. Late Triassic

2. Virginia (EC)

3. Weems, R. E., 1980, Geology of the Taylorsville basin, Hanover County, Virginia: Virginia Div. Mineral Resources Pub. 27, p. 24-27

4. Sandstone, conglomerate, siltstone, with minor shale, coal, and limestone

5. Black to gray, weathers dark red, grayish orange

6. $1,099 \mathrm{~m}$

7. Massive, cross-bedded

8. Stagg Creek, Falling Creek, and Newfound Members

9. Nonconformably overlies Petersburg Granite; unconformably underlies Miocene to Holocene age unconsolidated strata

10. Type section: Along Stagg Creek, beginning at Hanover Country Club $0.3 \mathrm{~km} \mathrm{~N}$ of Virginia Highway 54 and continuing $\mathrm{S}$ to contact with Petersburg Granite, Taylorsville basin, Hanover Academy quadrangle, Hanover County, Va. Named for village of Doswell.

Double Lakes Formation

1. Pleistocene (Wisconsinan)

2. Texas (NC), New Mexico

3. Reeves, C. C., Jr., 1976, Quaternary stratigraphy and geologic history of southern High Plains, Texas and New Mexico, in Mahaney, W. C., ed., Quaternary stratigraphy of North America: Stroudsburg, Pa., Dowden, Hutchinson and Ross, p. 221-222

4. Clay with epsomite and gypsum crystals

5. Olive-gray

6. $8.5 \mathrm{~m}$

7. Lacustrine basin fill

9. Lower contact not stated; underlies Tahoka Formation

10. Type section: Core depth-interval 14.02-22.56 m, Double Lakes basin, Lynn County, Tex.

Drakes Bay Formation

1. Miocene, late, or Pliocene, early

2. California (WC)

3. Galloway, A. J., 1977, Geology of the Point Reyes Peninsula, 
Marin County, California: California Div. Mines and Geology Bull. 202, p. 26-34

4. Basal glauconite-bearing greensand and overlying siltstone and mudstone

5. Green, cream to brown, gray to yellowish

6. $260 \mathrm{~m}$, range $\langle 1->490 \mathrm{~m}$, top eroded

7. Occupies syncline, $W$ of San Andreas fault zone

9. Unconformably overlies granitic basement rocks, Point Reyes Conglomerate, or Monterey Shale; unconformably underlies Quaternary sediments

10. Type section: Drakes Bay sea cliff extending from Drakes Estero [SW about $6 \mathrm{~km}$ ] to granitic outcrop at $E$ end of Point Reyes ridge, Marin County, Calif.

Druid Hill Amphibolite Member (James Run Formation)

1. Cambrian(?)

2. Maryland (NC)

3. Crowley, W. P., 1976, The geology of the crystalline rocks near Baltimore and its bearing on the evolution of the eastern Maryland Piedmont: Maryland Geol. Survey Rept. Inv. 27, p. $13-15$

4. Amphibolite with interlayered chlorite fels and actinofels

6. $700 \mathrm{~m}$

7. Fine- to medium-grained, well-foliated

9. Overlies(?) or in thrust-fault(?) contact with Hollofield Layered Ultramafite or Mount Washington Amphibolite (Baltimore Mafic Complex) in $\mathrm{E}-\mathrm{W}$ anticline; interfingers with Carroll Gneiss Member (James Run Formation); underlies Relay Gneiss Member (James Run Formation) or Jones Falls Schist in NE-SW syncline; intruded by Cold Spring Gneiss

10. Type locality: Outcrops along streams in Druid Hill Park, especially in ravine on $\mathrm{E}$ side of Druid Park Drive, Baltimore City, Baltimore County, Md.

\section{Drum Mountains Rhyodacite}

1. Eocene, late

2. Utah (WC)

3. Lindsey, D. A., 1979, Geologic map and cross-sections of Tertiary rocks in the Thomas Range and northern Drum Mountains, Juab County, Utah: U.S. Geol. Survey Misc. Inv. Ser. Map I-1176

4. Rhyodacite to quartz latite, with plagioclase and pyroxene phenocrysts

5. Black, rusty-weathering

7. Flows and breccias

9. Overlies Paleozoic rocks; underlies Mount Laird Tuff, or unconformably underlies Joy Tuff, Dell Tuff, or Spor Mountain Formation

10. Type locality: Exposures in Drum Mountains, secs. 32, 33, and 34, T. 14 S., R. 11 W., Juab County, Utah.

Dry Branch Formation (Barnwell Group)

1. Eocene, late

2. Georgia (C)

3. Huddlestun, P. F., and Hetrick, J. H., 1979, The stratigraphy of the Barnwell Group of Georgia: Georgia Geol.

Survey Open File Rept. 80-1, p. 17-25, 71-73

4. Sand, calcareous sand, clay, montmorillonite clay 
6. Range $9-54 \mathrm{~m}$

7. Three distinct but interfingering and intergrading lithofacies recognized as formal members in some areas; fossiliferous

8. Twiggs $\mathrm{Clay}$ Member, Irwinton Sand Member, Griffins Landing Sand Member

9. Overlies Clinchfield Formation (Barnwell Group) or Tivola Limestone (Ocala Group); conformably underlies Tobacco Road Sand (Barnwell Group)

10. Type locality: Exposure along railroad cut at highway bridge where U.S. Highway 80 passes over Seaboard Coast Line, $3.7 \mathrm{~km} \mathrm{~S}$ of community of Dry Branch, Twiggs County, $\mathrm{Ga}$.

\section{Dry Canyon Sandstone Member (Calabasas Formation)}

1. Miocene, middle

2. California (SC)

3. Yerkes, R. F., and Campbell, R. H., 1979, Stratigraphic nomenclature of the central Santa Monica Mountains, Los Angeles County, California: U.S. Geol. Survey Bull. 1457-E, p. E24

4. Sandstone, siltstone, dolomitic concretions in siltstone

6. $686 \mathrm{~m}$

7. Thin turbidites; broken coarse-grained arkosic arenite containing reworked(?) Miocene mollusks

9. Overlies Ramera Canyon Tongue (Conejo Volcanics); intertongues with Escondido Canyon Shale Member (Calabasas Formation) or Solstice Canyon Tongue (Conejo Volcanics); underlies Newell Sandstone Member (Calabasas Formation) or Malibu Bowl Tongue (Conejo Volcanics)

10. Type area: Dry Canyon, Santa Monica Mountains, WC Malibu Beach quadrangle, Los Angeles County, Calif.

Dtokoah Point Member (Makah Formation)

1. Eocene, late

2. Washington (NW)

3. Snavely, P. D., Jr., and others, 1980, Makah Formation--a deep-marginal-basin sequence of late Eocene and Oligocene age in the northwestern Olympic Peninsula, Washington: U.S. Geo1. Survey Prof. Paper 1162-B, p. 9-11

4. Sandstone, siltstone

5. Olive-gray

6. $65 \mathrm{~m}$

7. Fine-grained, rib-forming turbidite beds

9. Gradationally overlies and underlies unnamed strata in lower part of Makah Formation, above Baada Point Member and below Klachopis Point Member

10. Type section: Exposures on Dtokoah Point and wave-cut platform, NW1/4SE1/4 sec. 12, T. 33 N., R. 15 W., Strait of Juan de Fuca, Clallam County, Wash.

\section{Dutch Harbor Member (Unalaska Formation)}

1. Miocene, early(?)

2. Alaska ( $\mathrm{SC}$ )

3. Lankford, S. M., and Hill, J. M., 1979, Stratigraphy and depositional environment of the Dutch Harbor Member of the Unalaska Formation, Unalaska Island, Alaska: U.S. Geol. Survey Bull. 1457-B 
4. Sandstone with interbedded conglomerate

5. Light- to medium-greenish-gray

6. $126 \mathrm{~m}$

7. Very fine to fine-grained, indurated sandstone; rhythmically bedded turbidite and debris-flow deposits

9. Conformably overlies and underlies umamed lower and upper aquagene volcanic sequences of Unalaska Formation

10. Type section: Section measured about $3 \mathrm{~km} \mathrm{E}$ of village of Unalaska, Unalaska Island, Aleutian Islands, Alaska.

Dyer Canyon Formation

1. Triassic

2. Nevada (WC)

3. Speed, R. C., 1978, Basinal terrane of the early Mesozoic marine province of the western Great Basin, in Howell and McDougall, eds., Mesozoic paleogeography of the western United States: Soc. Econ. Paleontologists and Mineralogists, Pacific Sec., Pacific Coast Paleogeography Symposium 2, p. 237-252

4. Quartzose, detrital mica-rich sandstone with minor pelitic mudstone and laminite

6. $1,200 \mathrm{~m}$

9. Overlies Byers Canyon Formation; underlies Bernice Formation, all in the Clan Alpine sequence

10. Composite type section: Clan Alpine Mountains, lat $39^{\circ} 45^{\prime}$ N., long $117^{\circ} 45^{\prime}$ W., Churchill County, Nev. Named for Dyer Canyon.

Dygerts Bentonite Bed (Sinsinawa Member of Wise Lake Formation)

1. Middle Ordovician

2. Illinois (NW), Iowa, Minnesota

3. Willman, H. B., and Kolata, D. R., 1978, The Platteville and Galena Groups in northern Illinois: Illinois Geol. Survey Circ. 502, p. 52

4. Bentonite clay

6. $0.05 \mathrm{~m}$

9. Overlies and underlies dolomite units near middle of Sinsinawa Member

10. Type section: Galena Roadcut Section, roadcut on U.S. Highway 20 on $E$ side of Galena River, SW1/4SE1/4NE1/4 sec. 20, T. 28 N., R. 1 E., in Galena, Jo Daviess County, Ill. Named for Dygerts Mound, $2.4 \mathrm{~km}$ SE of type section.

Eagle Mountain Member (Paluxy Sand)

1. Early Cretaceous

2. Texas (C)

3. Owen, M. T., 1979, The Paluxy Sand in north-central Texas: Baylor Geol. Studies Bull. 36, p. 8, 25-29

4. Sand, clay

5. Purple, brown, white

6. $19 \mathrm{~m}$, range $2-23 \mathrm{~m}$

7. Cross-bedded, fossiliferous, fluvial and shallow marine deposits

9. Unconformably overlies Georges Creek Member (Paluxy Sand); unconformably underlies Walnut Clay

10. Type locality: Twin Points Resort at $E$ end of Eagle Mountain Lake spillway, Tarrant County, Tex. 


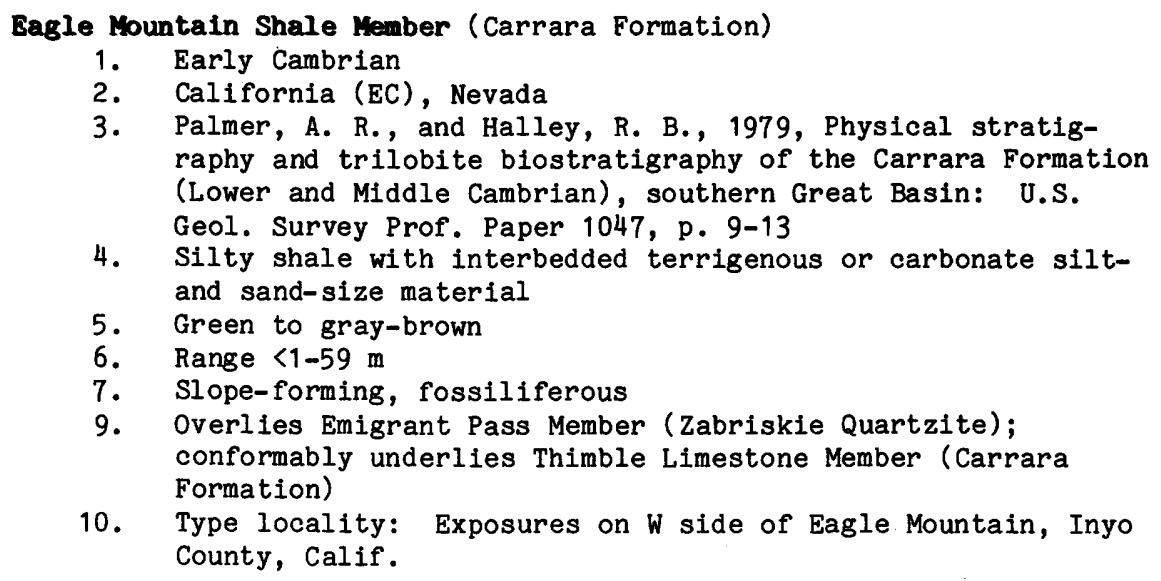

Easley Dolerite

1. Mesozoic

2. South Carolina (NW)

3. Snipes, D. S., and Furr, J. E., 1979, Easley Dolerite in the South Carolina Piedmont: South Carolina Geol. Survey Geol. Notes, v. 23, no. 2, p. 129-145

4. Dolerite

5. Dark-gray to black, weathers light brown

7. Dike 10-100 $\mathrm{m}$ wide, $14 \mathrm{~km}$ long, fine-grained, jointed

9. Intrudes Paleozoic metamorphic rocks

10. Type locality: Lat $34^{\circ} 50^{\prime} 32^{\prime \prime}$ N., long $82^{\circ} 30^{\prime} 35^{\prime \prime}$ W., $75 \mathrm{~m} \mathrm{~S}$ of Southern Railroad and $0.45 \mathrm{~km} \mathrm{~S} .74^{\circ} \mathrm{W}$. of trestle over Georges Creek, Pickens County, S.C. Named for town of Easley, $9.5 \mathrm{~km}$ W of type locality.

Eastover Formation (Chesapeake Group)

1. Miocene, late (Tortonian)

2. Virginia (SE), Maryland, North Carolina

3. Ward, L. W., and Blackwelder, B. W., 1980, Stratigraphic revision of upper Miocene and lower Pliocene beds of the Chesapeake Group, middle Altantic Coastal Plain: U.S. Geol. Survey Bull. 1482-D, p. D8-D28

4. Silty sand, clay, shelly sand

5. Greenish-gray, tan

6. $7 \mathrm{~m}$, range $6-24 \mathrm{~m}$

7. Fine-grained, fossiliferous

8. Claremont Manor and Cobham Bay Members

9. Unconformably overlies St. Marys Formation or, to S, progressively older sediments; unconformably underlies Sunken Meadow Member (Yorktown Formation)

10. Type section: Exposures $0.8 \mathrm{~km}$ above Mount Pleasant on $R$ bank of James River, $5.1 \mathrm{~km} \mathrm{E}$ of Eastover, Surry County, Va.

\section{Echo Shale Hember (Carrara Formation)}

1. Early Cambrian

2. California (EC), Nevada

3. Palmer, A. R., and Halley, R. B., 1979, Physical stratigraphy and trilobite biostratigraphy of the Carrara Formation (Lower and Middle Cambrian), southern Great Basin: U.S. Geol. Survey Prof. Paper 1047, p. 13 
4. Micaceous shale with calcareous intervals or interbedded limestone

5. Green, brown, orange

6. Range $<1-42 \mathrm{~m}$

7. Platy, generally unfossiliferous

9. Overlies Thimble Limestone Member; gradationally underlies Gold Ace Limestone Member, or is inseparable from Pyramid Shale Member where Gold Ace is absent

10. Type locality: Exposures at "Narrows" of Echo Canyon, Inyo County, Calif.

\section{Eckler Mountain Member (Wanapum Basalt)}

1. Miocene, middle

2. Washington (SE), Oregon

3. Swanson, D. A., and others, 1979, Revisions in stratigraphic nomenclature of the Columbia River Basalt Group: U.S. Geol. Survey Bull. 1457-G, p. G27-G31

4. Basalt

6. 20 to $25 \mathrm{~m}$

7. Coarse- to fine-grained, several flows

8. Informal basalt of Robinette Mountain, basalt of Dodge, and basalt of Shumaker Creek

9. Disconformably overlies Grande Ronde Basalt; disconformably underlies Frenchman Springs Member (Wanapum Basalt) (both formations in Yakima Basalt Subgroup of Columbia River Basalt Group)

10. Type locality: On S and SE sides of Eckler Mountain, about $17 \mathrm{~km} \mathrm{SE}$ of Dayton, $\mathrm{N} 1 / 2$ secs. 26 and $27, \mathrm{~T} .9 \mathrm{~N} ., \mathrm{R} .40 \mathrm{E}$., Eckler Mountain quadrangle, Columbia County, Wash.

\section{Ecor Rouge Sand}

1. Miocene, late

2. Alabama (SW)

3. Isphording, W. C., 1977, Petrology and stratigraphy of the Alabama Miocene: Gulf Coast Assoc. Geol. Socs. Trans., v. 27, p. $305-306$

4. Sand, gravelly sand, quartzite gravel

5. White, reddish-brown

6. $12 \mathrm{~m}$

7. Cross-bedded, fluvial marine clastics

9. Overlies Mobile Clay; underlies Citronelle Formation

10. Type locality: Ecor Rouge (Sea Cliff), on E shore of Mobile Bay near town of Fairhope, Baldwin County, Ala.

\section{Elkhead Limestone}

1. Middle Cambrian

2. Idaho (SE)

3. Trimble, D. E., and Carr, W. J., 1976, Geology of the Rockland and Arbon quadrangles, Power County, Idaho: U.S. Geol. Survey Bull. 1399, p. 12-13

4. Limestone, with interbedded shale unit

5. Gray

6. $640 \mathrm{~m}$

7. Thin-bedded, ledge-forming, platy, to thick-bedded to massive, oolitic; fossiliferous

9. Conformably overlies Gibson Jack Formation; conformably underlies Bloomington Formation

10. Type locality: Exposures both $\mathrm{E}$ and $\mathrm{W}$ of Midnight Creek, 
secs. $7,8,17$, and 18, T. 8 S., R. 34 E., Arbon quadrangle, Power County, Idaho. Named for Elkhead Ranch on Midnight Creek.

Elkport Bentonite Bed (Glenhaven Member of Guttenberg Formation)

1. Middle Ordovician

2. Iowa ( $\mathrm{NE})$, Illinois, Wisconsin

3. Willman, H. B., and Kolata, D. R., 1978, The Platteville and Galena Groups in northern Illinois: Illinois Geol. Survey Circ. 502, p. 45

4. Bentonite clay

5. Gray

6. $0.03 \mathrm{~m}$

9. Basal unit of Glenhaven Member; overlies Garnavillo Member (Guttenberg Formation)

10. Type section: Guttenberg North Section, roadcut on U.S. Highway 52, NW of Guttenberg, SW1/4SW1/4 sec. 5, T. 92 N., R. 2 W., Clayton County, Iowa. Named for town of Elkport, $14.5 \mathrm{~km}$ SW of type section.

Elwell Formation

1. Late Devonian

2. California (NC)

3. Durrell, Cordell, and DrAllura, Jad, 1977, Upper Paleozoic section in eastern Plumas and Sierra Counties, northern Sierra Nevada, California: Geol. Soc. America Bull., v. 88, no. 6 , p. $846-847$

4. Radiolarian chert interbedded with andesite tuff

5. Black, gray

6. $90 \mathrm{~m}$, range $90-300 \mathrm{~m}$

9. Overlies Sierra Buttes Formation; underlies Taylor Formation

10. Type area: Along ridge overlooking valley $W$ of Long Lake, SE1/4 sec. 12, T. 21 N., R. 11 E., Plumas County, Calif. Probably named for Mount Elwell, $0.5 \mathrm{~km}$ NW of Long Lake.

\section{Bmigrant Pass Member (Zabriskie Quartzite)}

1. Early Cambrian

2. California (EC), Nevada

3. Palmer, A. R., and Halley, R. B., 1979, Physical stratigraphy and trilobite biostratigraphy of the Carrara Formation (Lower and Middle Cambrian), southern Great Basin: U.S. Geol. Survey Prof. Paper 1047, p. 7-9

4. Quartzite, sandstone, minor siltstone and phyllitic shale

5. Maroon, brown, yellow, pale-green, pink, white

6. Range $<1-51 \mathrm{~m}$

7. Quartzite medium- to coarse-grained, laminated or low-angle crossbeds; mudcracks in upper part

9. As uppermost unit and only formal member, overlies main body of Zabriskie Quartzite; underlies Eagle Mountain Shale Member (Carrara Formation)

10. Type locality: Exposures $N$ of Emigrant Pass, NW1/4 sec. 25, T. 21 N., R. 8 E., S Nopah Range, Tecopa quadrangle, Inyo County, Calif.

\section{Emperor Volcanic Complex}

1. [Early Proterozoic]

2. Michigan (NW)

3. Trent, V. A., 1976, The Emperor Volcanic Complex of the East 
Gogebic Range, Michigan: U.S. Geol. Survey Bull. 1422-A, p. A69-A74

4. Basalt flows, flow-breccias, metagabbro, metadiorite, and metadiabase

5. Dark-gray to greenish-gray

6. $>700 \mathrm{~m}$

7. Dike swarm, phacoliths, sill, flows; prominent fold, fault, and joint formation; superimposed metamorphic grades

8. Wolf Mountain Creek Formation, youngest and only formally named unit

9. Overlies Palms Formation; underlies Copps Formation

10. Type locality: Exposures $\mathrm{N}$ and $\mathrm{W}$ of Kimberly Clark logging road, which runs $E$ to NNE through secs. 21,22 , and 15, T. 47 N., R. 44 W., Wakefield NE quadrangle, Gogebic County, Mich. Named for Emperor Creek, tributary of Little Presque Isle River, secs. 14 and 15, T. 47 N., R. 44 W.

Encampment River Granodiorite

1. Early Proterozoic

2. Wyoming (SC)

3. Divis, A. F., 1976, Geology and geochemistry of Sierra Madre Range, Wyoming: Colorado School Mines Quart., v. 71, no. 3, p. 30-31

4. Granodiorite

7. Well-follated, medium-grained

9. Intrudes Green Mountain Formation

10. Type area: Exposed in gorge of North Fork of Encampment River, Sierra Madre Range, Carbon County, Wyo.

Encinal Member (Topanga Canyon Formation)

1. Miocene, middle

2. California (SC)

3. Yerkes, R. F., and Campbell, R. H., 1979, Stratigraphic nomenclature of the central Santa Monica Mountains, Los Angeles County, California: U.S. Geol. Survey Bull. 1457-E, p. E15-E16

4. Siltstone or silty mudstone with dolomitic concretions

5. Dark-gray

6. $430 \mathrm{~m}$

7. Platy to shaly

9. Conformably overlies San Nicholas Member (Vaqueros Formation); unconformably underlies Conejo Volcanics (Topanga Group)

10. Type locality: Exposures on Encinal Canyon Road, secs. 21 and 28, T. 1 S., R. 19 W., lower Encinal Canyon, Santa Monica Mountains, Point Dume quadrangle, Los Angeles County, Calif.

Escalante Desert Formation

1. Oligocene

2. Utah (SW)

3. Grant, S. K., 1978, Stratigraphic relations of the Escalante Desert Formation near Lund, Utah: Brigham Young Univ. Geol. Studies, v. 25 , pt. 3 , p. $27-30$

4. Ash-flow tuff with interbedded volcaniclastic rocks

5. Pink, brown, lavender

6. $169 \mathrm{~m}$

7. Crystal-poor, lithic-bearing 
8. Informal lower, middle, and upper members, which include six ash-flow beds, A to F. [In Beaver County, NNW of type locality, D. R. Campbell (1978) subdivides formation into Lamerdorf Tuff Member and Beers Spring Member.]

9. Overlies unnamed volcanic conglomerate or informal tuff of Frisco; underlies Wah Wah Springs Tuff Member (Needles Range Formation)

10. Type section: NE flank of hill 6535, sec. 6, T. 32 S., R. 14 W., W margin of Escalante Desert, $S$ Wah Wah Mountains, Lund quadrangle, Iron County, Utah.

\section{Escondido Canyon Shale Member (Calabasas Formation)}

1. Miocene, middle

2. California (SC)

3. Yerkes, R. F., and Campbell, R. H., 1979, Stratigraphic nomenclature of the central Santa Monica Mountains, Los Angeles County, California: U.S. Geol. Survey Bull. 1457-E, p. E24

4. Siltstone, mudstone, shale, minor interbedded sandstone turbidites, dolomitic concretions in siltstone

6. $276 \mathrm{~m}$

9. Overlies Ramera Canyon Tongue (Conejo Volcanics); intertongues with Dry Canyon Sandstone Member (Calabasas Formation); underlies Latigo Canyon Breccia Member (Calabasas Formation)

10. Type area: Escondido Canyon, Santa Monica Mountains, EC Point Dume quadrangle, Los Angeles County, Calif.

Esquatzel Member (Saddle Mountains Basalt)

1. Miocene, middle

2. Washington (SE)

3. Swanson, D. A., and others, 1979, Revisions in stratigraphic nomenclature of the Columbia River Basalt Group: U.S. Geol. Survey Bull. 1457-G, p. G45-G46

4. Plagioclase- and clinopyroxene-phyric basalt

6. Range $<10-50 \mathrm{~m}$

7. One flow

9. Unconformably overlies Priest Rapids Member (Wanapum Basalt); underlies Pomona Member (Saddle Mountains Basalt)

10. Type locality: Hillslope on $\mathrm{N}$ side of Esquatzel Coulee, elevation 223-241 m, NW1/4NW1/4 sec. 25, T. 13 N., R. 30 E., $1 \mathrm{~km} \mathrm{~N}$ of Mesa, Mesa quadrangle, Franklin County, Wash.

\section{Bureka Canyon Tuff}

\section{Oligocene}

2. Nevada (WC)

3. Bingler, E. C., 1978, Abandonment of the name Hartford Hill Rhyolite Tuff and adoption of new formation names for middle Tertiary ash-flow tuffs in the Carson City-Silver City area, Nevada: U.S. Geol. Survey Bull. 1457-D, p. D14-D16

4. Rhyolite tuff

5. White to pale-gray, lavender, and tan

6. $130 \mathrm{~m}$, range $130-150 \mathrm{~m}$

7. Vitric, distinct cooling zonation; mostly devitrified, weakly welded, with zones of vitrophyre; very uniform in primary texture and composition

9. Disconformably overlies Nine Hills Tuff; disconformably underlies younger Tertiary tuffs 
10. Type section: Exposures in Eureka Canyon, at common boundary between secs. 32 and 33, T. 16 N., R. 21 E., New Empire quadrangle, Lyon County, Nev.

\section{Facer Formation}

1. Early Proterozoic

2. Utah (NC)

3. Crittenden, M. D., Jr., and Sorensen, M. L., 1980, The Facer Formation, a new early Proterozoic unit in northern Utah:

U.S. Geol. Survey Bull. 1482-F, p. F1-F28

4. Quartzite, pelitic schist, minor limestone and conglomerate

5. White to pale-rusty-brown, bright-green

6. $1,000 \mathrm{~m}$

7. Low-grade regional metamorphism; quartzite forms cliffs, ledges, supports highest peaks

9. Base everywhere in thrust contact with Paleozoic rocks; unconformably underlies Huntsville sequence of Late Proterozoic and Early Cambrian age

10. Type section: Exposures from $\mathrm{N}$ slope Willard Canyon, $\mathrm{N} 1 / 2$ sec. 19, T. 8 N., R. 1 W., to head of Facer Creek, SE1/4 sec. 18, T. 18 N., R. 1 W., W face of Wasatch Mountains, $S$ of Brigham City, Mantua quadrangle, Box Elder County, Utah. Named for Facer Creek.

\section{Factory Shoals Formation (Sandy Springs Group)}

1. Precambrian, late(?) and (or) Paleozoic, early(?)

2. Georgia (NW)

3. Higgins, M. W:, and McConnell, K. I., 1978, The Sandy Springs Group and related rocks in the Georgia Piedmont-nomenclature and stratigraphy:. U.S. Geol. Survey Bull. 1457-A, p. A103 (Also published in: Georgia Geol. Survey Bull. 93, p. 53, 1978)

4. Garnet-biotite-oligoclase-muscovite-quartz schist locally containing kyanite or staurolite, with interlayered micaceous quartzite and metagraywacke

5. Light-gray, lustrous

6. Range 1,000-2,000 m

9. Gradationally overlies Chattahoochee Palisades Quartzite; gradationally underlies Rottenwood Creek Quartzite

10. Type area: Exposures along Sweetwater Creek at Factory Shoals, Ben Hill quadrangle, Fulton County, Ga.

\section{Fall Brook Formation}

1. Late Silurian or Early Devonian

2. Maine (WC)

3. Pankiwskyj, K. A., and others, 1976, Stratigraphic relationships on the southeast limb of the Merrimack synclinorium in central and west-central Maine: Geol. Soc. America Mem. 146, p. 270,275

4. Calcareous metasandstone, minor metapelite and metasiltstone

6. Range 600-1,000 m

7. Massive

9. Overlies Parkman Hill Formation (in type locality), or Thompson Mountain or Sangerville Formation; conformably and gradationally underlies Solon Formation

10. Type locality: Fall Brook in village of Solon, $\mathbf{N}$ Anson quadrangle, Somerset County, Maine. 
Falling Creek Member (Doswell Formation)

1. Late Triassic

2. Virginia (EC)

3. Weems, R. E., 1980, Geology of the Taylorsville basin, Hanover County, Virginia: Virginia Div. Mineral Resources Pub. 27, p. 25-26

4. Sandstone with interbedded siltstone, shale, and coal

5. Black, green, grayish-orange

6. $354 \mathrm{~m}$

7. Laminated, flaggy sandstone, bioturbated siltstone, fossiliferous

9. Conformably overlies Stagg Creek Member; conformably underlies Newfound Member

10. Type section: Along Stagg Creek, beginning at Hanover Country Club $0.3 \mathrm{~km} \mathrm{~N}$ of Virginia Highway 54 and continuing $S$ to contact with Petersburg Granite, Taylorsville basin, Hanover Academy quadrangle, Hanover County, Va. Named for Falling Creek $3.4 \mathrm{~km} \mathrm{NW}$ of junction of U.S. Highway 1 and Virginia Highway 54 in Ashland.

Falls Run Granite Gneiss (Fredericksburg Complex)

1. Middle Silurian to Early Devonian

2. Virginia (EC)

3. Pavlides, Louis, 1980, Revised nomenclature and stratigraphic relationships of the Fredericksburg Complex and Quantico Formation of the Virginia Piedmont: U.S. Geol. Survey Prof. Paper 1146, p. 12-15

4. Granite gneiss

5. Pale-pink to white

7. Coarse-grained, foliated, allochthonous refolded fold in type area

9. Intrudes Holly Corner Gneiss and ( $S$ of type area) Po River Metamorphic Suite (autochthonous)

10. Type area: Downstream from intersection of Falls Run and Virginia Route 654, Salem Church quadrangle, Stafford County, Va.

\section{Falmouth Intrusive Suite}

1. Carboniferous

2. Virginia (EC)

3. Pavlides, Louis, 1980, Revised nomenclature and stratigraphic relationships of the Fredericksburg Complex and Quantico Formation of the Virginia Piedmont: U.S. Geol. Survey Prof. Paper 1146, p. 20-22

4. Granitoid and pegmatoid rocks

7. Foliated granitoid, nonfoliated pegmatoid; dikes, sills, small plutons

9. Intrudes Po River and Ta River Metamorphic Suites, Holly Corner Gneiss, and Falls Run Granite Gneiss, (all in Fredericksburg Complex), and Quantico Formation

10. Type area: Exposures along Rappahannock River upstream from town of Falmouth, Stafford County, Va.

Feltville Formation (Newark Supergroup)

1. Early Jurassic

2. New Jersey (NE)

3. Olsen, P. E., 1980, The latest Triassic and Early Jurassic formations of the Newark Basin (eastern North America, 
Newark Supergroup)--stratigraphy, structure, and correlation: New Jersey Acad. Sci. Bull., v. 25, no. 2, p. 34

4. Interbedded siltstone and sandstone in fining-upwards sequences; laminated limestone containing fossil fishes

5. Red, buff, gray, white

6. $170 \mathrm{~m}$ avg, range $>18-600 \mathrm{~m}$

9. Overlies Orange Mountain Basalt; underlies Preakness Basalt. Unit was formerly a subdivision of upper part of Brunswick Formation of Kümmel (1897)

10. Type section: Exposure along Blue Brook, $1 \mathrm{~km}$ SW of dam at Lake Surprise, Watchung Reservation (Union County Park Commission), Union County, N.J. Named for old village of Feltville.

Fernwood Member (Topanga Canyon Formation)

1. Miocene, middle

2. California (SC)

3. Yerkes, R. F., and Campbell, R. H., 1979, Stratigraphic nomenclature of the central Santa Monica Mountains, Los Angeles County, California: U.S. Geol. Survey Bull. 1457-E, p. E16-E17

4. Sandstone interbedded with mudstone

6. $>375 \mathrm{~m}$

7. Fluvial to brackish-water pebbly sandstone in thick lenticular ledge-forming beds, channeled and crossbedded

9. Conformably overlies and tongues into Saddle Peak Member; conformably underlies and tongues into Cold Creek Member

10. Type locality: Exposures in vicinity of Fernwood, secs. 18 and 19, T. 1 S., R. $16 \mathrm{~W}$. , and secs. 13 and 24, T. 1 S., R. 17 W., Santa Monica Mountains, Topanga quadrangle, Los Angeles County, Calif.

Ferron Mountain Member (Flagstaff Limestone)

1. Paleocene, late

2. Utah (C)

3. Stanley, K. O., and Collinson, J. W., 1979, Depositional history of Paleocene-lower Eocene Flagstaff Limestone and coeval rocks, central Utah: Am. Assoc. Petroleum Geologists Bull., v. 63, no. 3, p. 316

4. Interbedded limestone, dolomicrite, mudstone, with sandstone lenses

5. Blue-gray, gray, white

6. $165 \mathrm{~m}$

7. Brecciated, fossiliferous (mollusks); represents lower of two major high stands of Lake Flagstaff

8. Eight informal units, A through $H$

9. Conformably overlies North Horn Formation; underlies Cove Mountain Member (Flagstaff Limestone)

10. Type locality: Cliffs and slopes along $S$ face of Ferron Mountain, sec. 32, T. 19 S., R. 5 E., Wasatch Plateau, Sanpete County, Utah.

Finch Dolostone Member (Whitehall Formation)

1. Late Cambrian

2. New York (NE), Vermont

3. Fisher, D. W., 1977, Correlation of the Hadrynian, Cambrian and Ordovician rocks in New York State: New York State Mus. Map and Chart Ser., no. 25, p. 49 
4. Dolostone with interbedded chert

5. Medium-gray

6. $\quad 12.2 \mathrm{~m}$, range $12.2-22.8 \mathrm{~m}$

7. Thin- to thick-bedded, laminated, fetid odor, abundant quartz vugs

9. Overlies basal orthoquartzite (Mosherville Sandstone?) member; underlies Warner Hill Limestone Member

10. Type locality: Ward Farm, $6.4 \mathrm{~km}$ NNE of intersection of U.S. Highway 4 and New York Highway 22 in Whitehall, Thorn Hill quadrangle, Washington County, N.Y. Named for Finch Marsh, $3.7 \mathrm{~km}$ NNE of Whitehall.

Fine Creek Mills Granite

1. Paleozoic, late(?)

2. Virginia (EC)

3. Poland, F. B., Glover, Lynn, III, and Mose, D. G., 1979, The geology of the rocks along the James River between Sabot and Cedar Point, Virginia, in Glover, Lynn, III, and Tucker, R. D., eds., Virginia Piedmont geology along the James River from Richmond to the Blue Ridge--Field trip 1, of Guides to field trips 1-3: Blacksburg, Va., Geol. Soc. America, Southeastern Sec., p. 13

4. Two-feldspar biotite granite

7. Foliation, flow-banding

9. Intrudes State Farm Gneiss in core of NNE-trending antiform

10. Type area: Exposures at Fine Creek Mills, $S$ of James River, Powhatan County, Va.

Fisher Ridge Member (Mahantango Formation)

1. Middle Devonian

2. Pennsylvania (C)

3. Faill, R. T., Hoskins, D. M., and Wells, R. B., 1978, Middle Devonian stratigraphy in central Pennsylvania--a revision: Pennsylvania Geol. Survey, 4 th ser., Gen. Geology Rept. 70, p. $14,23-28$

4. Shale, siltstone

5. Olive-gray

6. $139 \mathrm{~m}$, range $39-300 \mathrm{~m}$

7. Cyclic deposits, uniformly fine grained; lower part of major upward-coarsening cycle

9. Overlies Dalmatia Member (Mahantango Formation) or Marcellus Formation where Turkey Ridge and Dalmatia Members are absent; underlies Montebello Member (Mahantango Formation)

10. Type section: First and second abandoned quarries, counting from $S$, and quarry access road, along $E$ side of Penn Central Railroad, at $W$ end of Fisher Ridge, $4 \mathrm{~km} S$ of Dalmatia, Northumberland County, $\mathrm{Pa}$.

Fish Lake Complex

1. Jurassic

2. Alaska (EC)

3. Stout, J. H., 1976, Geology of the Eureka Creek area, eastcentral Alaska Range: Alaska Div. Geol. and Geophys.

Surveys Geol. Rept. 46, p. 21-23

4. Dunite, gabbro, minor diorite

7. Intrusive bodies and related gabbro dikes, conforming to bedding trends; compositional layering suggests differentiated layered sill 
9. Intrusive into, and between, Paxson Mountain Basalt and Tangle Lakes Formation (Amphi theater Group); unconformably underlies Tertiary rocks

10. Type locality: Exposures of main dunite body in low hills around Fish Lake, Eureka Creek area, Mount Hayes A-4 and A-5 quadrangles, EC Alaska Range, Alaska.

\section{Flint Hill Gneiss}

1. Middle Proterozoic

2. Virginia (NC)

3. Lukert, M. T., Nuckols, E. B., and Clarke, J. W., 1977, Flint Hill Gneiss--a definition: Southeastern Geology, v. 19 , no. 1 , p. 19-28

4. Biotite gneiss of granitic composition with veins of blue quartz

5. Dark and light layers

7. Finely layered, strongly foliated

9. Intruded by Robertson River Formation and basaltic greenstone dikes

10. Type locality: Large quarry $0.8 \mathrm{~km} \mathrm{E}$ of community of Flint Hill, Rappahannock County, Va.

Fogelin Hill Formation

1. Late Silurian and Early Devonian(?) (Ludlovian to Siegenian?)

2. Maine (NE)

3. Roy, D. C., and Mencher, Ely, 1976, Ordovician and Silurian stratigraphy of northeastern Aroostook County, Maine: Geol. Soc. America Mem. 148, p. 41, 50

4. Slate interlayered with calcareous sandstone and siltstone

5. Light green and red

6. $>760 \mathrm{~m}$

9. Conformably overlies Jemtland Formation (Perham Group); top not observed (forms axial terrain of Stockholm Mountain syncline)

10. Type area: Exposures in village of Stockholm and along N-S road between Stockholm and Jemtland, Aroostook County, Maine. Named for Fogelin Hill, SW of Jemtland.

Fort Edward Dolostone Member (Great Meadows Formation)

1. Early Ordovician

2. New York (NE), Vermont

3. Fisher, D. W., 1977, Correlation of the Hadrynian, Cambrian and Ordovician rocks in New York State: New York State Mus. Map and Chart Ser., no. 25, p. 56

4. Quartzose and calcitic dolostone

5. Mottled

6. Range 18.2-45.5 m

7. Medium- to thick-bedded, vermicular, fossiliferous

9. Transitionally overlies Winchell Creek Siltstone Member; abruptly underlies Smith Basin Limestone Member

10. Type locality: Bushlea Farm, $N$ of New York Highway 149 and $1.6 \mathrm{~km} \mathrm{E}$ of Smiths Basin on Champlain Canal, Hartford quadrangle, Washington County, N.Y. Named for village of Fort Edward, $16 \mathrm{~km}$ SW of type locality.

Fort Pond Member (Nashoba Formation)

1. pre-Silurian 
2. Massachusetts (C)

3. Bell, K. G., and Alvord, D. C., 1976, Pre-Silurian stratigraphy of northeastern Massachusetts: Geol. Soc. America Mem. 148, p. 184-185, 208, app. 1 (in pocket)

4. Calc-silicate rocks with discontinuous beds of marble; amphibole-biotite gneiss; amphibolite

6. $1,470 \mathrm{~m}$

7. Fine- to medium-grained, stratified, relict sedimentary structures

9. Overlies Nagog Pond Gneiss Member; underlies Long Pond Gneiss Member

10. Type locality: Area near SE, NW, and SW shores of Fort Pond in town of Littleton, Westford quadrangle, Middlesex County, Mass.

Foss Group

1. Late Permian

2. Oklahoma (C)

3. Fay, R. 0., 1978, Geology and mineral resources (exclusive of petroleum) of Custer County, Oklahoma: Oklahoma Geol. Survey Bull. 114, p. 19-35

4. Shale, siltstone

5. Orange-brown, red-brown

6. $110 \mathrm{~m}$

8. Cloud Chief Formation with its Moccasin Creek Bed, Kiger Member, Day Creek Bed, and Big Basin Member; Doxey Shale

9. Overlies Rush Springs Formation (Whitehorse Group); underlies Elk City Sandstone

10. Type locality: S side of Foss Reservoir between Clinton and Hammon, Custer County, Okla. Named for town of Foss, Washita County.

Fossil Hill Member (Prida Formation)/Member (Favret Formation)/ Formation (Star Peak Group)

1. Middle Triassic (Anisian and Ladinian)

2. Nevada (NW)

3. Nichols, K. M., and Silberling, N. J., 1977, Stratigraphy and depositional history of the Star Peak Group (Triassic), northwestern Nevada: Geol. Soc. America Spec. Paper 178, p. $20-23,39-41,45-48$

4. Interstratified limestone, calcareous mudstone, siltstone, and shale

5. Dark-gray, yellowish-brown, pinkish-gray

6. $60 \mathrm{~m}$, range $<1-200 \mathrm{~m}$

7. Fossiliferous, flaggy, laterally discontinuous beds, platform carbonate deposit

9. Disconformably overlies unnamed lower member and gradationally underlies unnamed upper member of Prida Formation (Star Peak Group)

10. Type section: S side of Fossil Hill, NW1/4SE1/4 sec. 19, T. 28 N., R. 35 E., SE Humboldt Range, Pershing County, Nev.

Frame Member (Wristen Formation)

1. Late Silurian

2. Texas (WC)

3. Hills, J. M., and Hoenig, M. A., 1979, Proposed type sections for Upper Silurian and Lower Devonian subsurface units in Permian Basin, west Texas: Am. Assoc. Petroleum 
Geologists Bull., v. 63, no. 9, p. 1510-1511

4. Calcareous shale, shaly limestone

5. Green-gray, blue-gray

6. $61 \mathrm{~m}$, range $<1-61 \mathrm{~m}$

9. Conformably overlies Wirk Member (Wristen Formation); unconformably underlies Thirtyone Formation

10. Type section: Wilshire 0il Co. 1 Atlantic Frame well, depth-interval 2036-2097 m, Sec. 8, Blk. 10, H \& GN Survey, Pecos County, Tex.

Franklinville Gneiss

1. Cambrian-Ordovician(?)

2. Maryland (NC)

3. Crowley, W. P., 1976, The geology of the crystalline rocks near Baltimore and its bearing on the evolution of the eastern Maryland Piedmont: Maryland Geol. Survey Rept. Inv. 27, p. 16

4. Biotite-quartz-plagioclase gneiss

7. Medium- to coarse-grained

9. Overlies Bradshaw Layered Amphibolite (Baltimore Mafic Complex) in NE-SW syncline

10. Type locality: Outcrops on either side of bridge that crosses Little Gunpowder Falls at Franklinville, White Marsh quadrangle, Baltimore County, Md.

Furner Valley Limestone (Oquirrh Group)

1. Late Pennsylvanian and Early Permian (Missourian to Wolfcampian)

2. Utah (C)

3. Morris, H. T., Douglass, R. C., and Kopf, R. W., 1977, Stratigraphy and microfaunas of the Oquirrh Group in the southern East Tintic Mountains, Utah: U.S. Geol. Survey Prof. Paper 1025, p. 6-8

4. Limestone with chert masses, hydrothermal dolomite

5. Gray, blue-gray

6. $1,595 \mathrm{~m}$, range 1,524-1,829 $\mathrm{m}$

7. Thin- to medium-bedded, ledge-forming, fossiliferous (fusulinids)

9. Conformably overlies Bingham Mine Formation (Oquirrh Group); disconformably underlies Diamond Creek Sandstone

10. Type section: E side of Jericho Ridge, E1/2 secs. 6, 7, and 18 , T. 13 S., R. 2 W., S East Tintic Mountains, Furner Ridge quadrangle, Juab County, Utah. Named for Furner Valley, which separates Jericho and Furner Ridges.

Gallagher Peak Sandstone Member (Snaky Canyon Formation)

1. Late Pennsylvanian (Missourian)

2. Idaho (SE)

3. Skipp, Betty, and others, 1979, Upper Paleozoic carbonate bank in east-central Idaho--Snaky Canyon, Bluebird Mountain, and Arco Hills Formations, and their paleotectonic significance: U.S. Geol. Survey Bull. 1486, p. 28-29

4. Calcareous, quartzose sandstone

5. Medium-gray and light-brownish-gray

6. $59 \mathrm{~m}$

7. Very fine grained, thin-bedded

9. Gradationally overlies Bloom Member; gradationally underlies Juniper Gulch Member 
10. Type section: Exposures on summit of Gallagher Peak, sec. 21 , T. 9 N., R. 32 E., Copper Mountain quadrangle, Clark County, Idaho.

Gene Canyon Formation

1. Oligocene(?), late, to Miocene, early

2. California (SE), Arizona

3. Davis, G. A., and others, 1980, Mylonitization and detachment faulting in the Whipple-Buckskin-Rawhide Mountains terrane, southeastern California and western Arizona: Geol. Soc. America Mem. 153, p. 93-95

4. Sandstone, interbedded with andesitic(?) volcanic rocks, debris flows of crystalline rocks, siltstone, and limestone

5. Red, buff

6. $585 \mathrm{~m}$

7. Unit in allochthonous upper-plate assemblage separated from lower-plate assemblage by subhorizontal detachment fault

9. Overlies upper-plate crystalline basement rocks; unconformably underlies Copper Basin Formation or Osborne Wash Formation

10. Type area: Gene Canyon, E Whipple Mountains, Gene Wash quadrangle, San Bernardino County, Calif.

Georges Creek Member (Paluxy Sand)

1. Early Cretaceous

2. Texas (C)

3. Owen, M. T., 1979, The Paluxy Sand in north-central Texas: Baylor Geol. Studies Bull. 36, p. 8, 21-25

4. Sand, silt, clay, sandstone, limestone

5. Red, white

6. $10 \mathrm{~m}$, range $2-31 \mathrm{~m}$

7. Cross-bedded, fluvial and subtidal deposits

9. Disconformably overlies Lake Merritt Member; unconformably underlies Eagle Mountain Member

10. Type locality: Georges Creek along county road at Capitol Silica Quarry, $12.8 \mathrm{~km}$ E of Glen Rose, Somervell County, Tex.

Gettel Member (Laketown Dolostone)

1. Middle Silurian

2. Utah (WC), Nevada

3. Budge, D. R., and Sheehan, P. M., 1980, The Upper Ordovician through Middle Silurian of the eastern Great Basin--Pt. 1, Introduction--historical perspective and stratigraphic synthesis; Pt. 2, Lithologic descriptions: Milwaukee Public Mus. Contr. Biology and Geology, no. 28, p. 19-20 (pt. 1); no. 29, p. 17 (pt. 2)

4. Argillaceous dolomite

5. Olive-gray, weathers brownish gray

6. $11.6 \mathrm{~m}$

7. Finely crystalline, medium- to thick-bedded, fossiliferous

9. Overlies High Lake Member; underlies Portage Canyon Member or, as at type section, Jack Valley Member

10. Type section: W of Gettel Playa, NE1/4SW1/4 sec. 26, T. 21 S., R. 14 W., Barn Hills, Confusion Range, Millard County, Utah. Unit is restricted to $S$ part of study area. 
Ghost Dance Lava Member (Hu-pwi Rhyodacite)

1. Miocene

2. Nevada (WC)

3. Ekren, E. B., and others, 1980, Stratigraphy, preliminary petrology, and some structural features of Tertiary volcanic rocks in the Gabbs Valley and Gillis Ranges, Mineral County, Nevada: U.S. Geol. Survey Bull. 1464, p. 38-39

4. Rhyodacitic flow breccia and lava

5. Brownish-gray, black

6. Range $<1-100 \mathrm{~m}$

7. Porphyritic, flow-banded lava with layers alternately rich and poor in phenocrysts

9. Overlies Nugent Tuff Member; underlies Poinsettia Tuff Member; contacts are low-angle detachment faults

10. Type locality: Hidden Wash, $3.2 \mathrm{~km} \mathrm{E}$ of Ghost Dance Ridge, T. 11 N., R. 30 E., Gillis Range, Mineral County, Nev.

\section{Gibraltar Lake Tuff}

1. Oligocene(?) to Pliocene(?)

2. Alaska (C)

3. Detterman, R. L., and Reed, B. L., 1980, Stratigraphy, structure, and economic geology of the Iliamna quadrangle, Alaska: U.S. Geol. Survey Bull. 1368-B, p. B56-B58

4. Rhyolitic crystal and lithic tuff

5. Lower member: light-gray to tan; upper member: light-gray to white

6. Lower member: range $300-730 \mathrm{~m}$; upper member: range 30$182 \mathrm{~m}$

8. Informal lower welded tuff member and upper ash-flow tuff member

9. Unconformably overlies older Tertiary volcanic rocks; locally unconformably underlies Intricate Basalt

10. Type locality: Exposures on mountain $W$ of Emerald Lake, $S$ of Iliamna Lake, Iliamna quadrangle, Alaska Peninsula, Alaska. Named for nearby Gibraltar Lake.

\section{Gilmer Limestone (Louark Group)}

1. Late Jurassic

2. Texas (EC)

3. Forgotson, J. M., and Forgotson, J. M., Jr., 1976, Definition of Gilmer Limestone, Upper Jurassic formation, northeastern Texas: Am. Assoc. Petroleum Geologists Bull., v. 60 , no. 7 , p. 1119-1123

4. Micritic limestone, oolitic limestone, shale

5. Gray, brown

6. $97 \mathrm{~m}$

7. Subsurface, depositional basin

9. Overlies Smackover Formation or Buckner Formation (Louark Group); unconformably underlies Bossier Formation (Cotton Valley Group)

10. Type section: Arkansas Louisiana Gas Co. Indian Rock Gas Unit 2 well, depth-interval $3542-3639 \mathrm{~m}$, Maria Finolia Flores Survey A-2, Gilmer field, $5 \mathrm{~km} \mathrm{E}$ of Gilmer, Upshur County, Tex.

Glen Creek Gabbro (Roosevelt Gabbros)

1. Cambrian

2. Oklahoma (C) 
3. Powell, B. N., Gilbert, M. C., and Fischer, J. F., 1980, Lithostratigraphic classification of basement rocks of the Wichita province, Oklahoma--summary: Geol. Soc. America Bull., pt. 1, v. 91, no. 9, p. 510-513

4. Biotite-amphibole-olivine gabbro with ultramafic segregations and concentrations of magnetite and ilmenite

5. Weathers olive brown

6. $>30 \mathrm{~m}$

7. Ophitic, poikilitic, medium-grained, sill-like intrusive body

9. Intrudes Glen Mountains Layered Complex (Raggedy Mountain Gabbro Group)

10. Type locality: Outcrops $W$ of Glen Creek, NE1/4SW1/4 sec. 14, T. 4 N., R. 17 W., Glen Mountains, Kiowa County, Okla.

Glen Mountains Layered Complex (Raggedy Mountain Gabbro Group)

1. Precambrian to Cambrian

2. Oklahoma (C)

3. Powell, B. N., Gilbert, M. C., and Fischer, J. F., 1980, Lithostratigraphic classification of basement rocks of the Wichita province, Oklahoma--summary: Geol. Soc. America Bull., pt. 1, v. 91, no. 9, p. 509-510

4. Feldspathic cumulates including anorthosite, anorthositic gabbro, and troctolite

5. Tan, light-gray

6. $>240 \mathrm{~m}$

7. Medium- to coarse-grained, igneous lamination and gravitational layering

8. Informal $\mathrm{G}, \mathrm{K}, \mathrm{L}$, and $\mathrm{M}$ zones

9. Base not exposed; intruded by Roosevelt Gabbros; underlies sills of younger granites emplaced along erosional unconformity between complex and overlying Carlton Rhyolite Group

10. Type area: Glen Mountains, T. 4 N., Rs. 16 and 17 W., Kiowa County, Okla.

Glen Township Formation (Mille Lacs Group)

1. Precambrian, middle

2. Minnesota (C)

3. Morey, G. B., 1978, Lower and middle Precambrian stratigraphic nomenclature for east-central Minnesota: Minnesota Geol. Survey Rept. Inv. 21, p. 20-21

4. Interbedded sulfide-rich carbonaceous slate, cherty ironformation, metabasalt, and epiclastic sedimentary rocks

6. $3,000 \mathrm{~m}$

7. Highly metamorphosed

9. Overlies and grades laterally into Denham Formation (Mille Lacs Group); underlies argillaceous rocks of Mille Lacs Group, undivided

10. Type locality: Drilling logs and core samples from 55 holes in sec. 28, T. 46 N., R. 25 W., Glen Township, Aitkin County, Minn.

Goat Mountain Schists

1. Middle Jurassic(?)

2. California (NW)

3. Suppe, John, and Foland, K. A., 1978, The Goat Mountain Schists and Pacific Ridge Complex: A redeformed but still- 
intact late Mesozoic Franciscan schuppen complex, in Howell and McDougall, eds., Mesozoic paleogeography of the western United States: Soc. Econ. Paleontologists and Mineralogists, Pacific Sec., Pacific Coast Paleogeography Symposium 2, p. 431-451

4. Coarsely crystalline hornblende schist, metabasalt, metachert, actinolite-chlorite schist, and serpentinite

7. Coarse-grained

9. Structurally interlayered with Pacific Ridge Complex in Franciscan terrane

10. Type area: $800 \mathrm{~m}$ along ridge extending $\mathrm{W}$ from Goat Mountain summit, lat $39^{\circ} 30^{\prime}$ N., long $122^{\circ} 45^{\prime}$ W. , Stonyford quadrangle, Lake County, Calif.

Gold Ace Limestone Member (Carrara Formation)

1. Early Cambrian

2. Nevada (SC), California

3. Palmer, A. R., and Halley, R. B., 1979, Physical stratigraphy and trilobite biostratigraphy of the Carrara Formation (Lower and Middle Cambrian), southern Great Basin: U.S. Geol. Survey Prof. Paper 1047, p. 13-14

4. Microspar limestone deposited as lime mudstone

5. Dark-gray

6. $46 \mathrm{~m}$, range $<1-103 \mathrm{~m}$

7. Thin- to medium-bedded, cliff-forming, burrowed, oncolitic, fossil fragments

9. Gradationally overlies Echo Shale Member; underlies with sharp contact Pyramid Shale Member

10. Type section: Exposure in canyon $0.8 \mathrm{~km} \mathrm{NW}$ of Carrara Canyon, near Gold Ace Mine, Bare Mountain quadrangle, Nye County, Nev.

Goose Creek Conglomerate Member (Bull Run Formation)

1. Late Triassic

2. Virginia (NE)

3. Lindholm, R. C., 1979, Geologic history and stratigraphy of the Triassic-Jurassic Culpeper Basin, Virginia: Geol. Soc. America Bull. (pts. 1 and 2), v. 90, no. 11, p. 996 (pt. 1, summary); p. 1721-1722 (pt. 2, microfiche)

4. Silicate pebble conglomerate

5. Greenish and grayish pebbles

6. $>900 \mathrm{~m}$

7. Member separated on basis of clast lithology; clasts derived from metamorphic rocks of the Blue Ridge province

9. Conglomeratic masses within main body of Bull Run Formation in its upper part; underlies Buckland Formation on $W$ side of Culpeper basin

10. Type locality: Exposures on $\mathrm{S}$ side of Goose Creek, $2 \mathrm{~km} \mathrm{E}$ of confluence of Goose Creek and Little River, Culpeper basin, Loudoun County, Va.

Gordon Pass Formation (Big Cypress Group)

1. Early Cretaceous (Comanchean)

2. Florida (SE)

3. Winston, G. D., 1976, Six proposed formations in the undefined portion of the Lower Cretaceous section in south Florida: Gulf Coast Assoc. Geol. Socs. Trans., v. 26, p. 71

4. Anhydrite interbedded with micritic limestone and dolomite 


\section{6. $159 \mathrm{~m}$}

7. Dense limestone at base, thin anhydrite bed at top

9. Overlies Marco Junction Formation; underlies Dollar Bay Formation

10. Type section: Humble No. 1 Collier Corp. well, depthinterval 3,109-3,268 m, sec. 27, T. 50 S., R. 26 E., Collier County, Fla. Named for Gordon Pass, which connects Gulf of Mexico with barrier-beach lagoon $9.6 \mathrm{~km}$ W of type well.

Grande Ronde Basalt (Yakima Basalt Subgroup of Columbia River Basalt Group)

1. Miocene, early and middle

2. Washington (SE), Idaho, Oregon

3. Swanson, D. A., and others, 1979, Revisions in stratigraphic nomenclature of the Columbia River Basalt Group: U.S. Geol. Survey Bull. 1457-G, P. G16-G24

4. Tholeitic basalt

6. Range 450-1,000 m

7. Fine-grained, aphyric, cliff-forming, numerous flows range $<1->100 \mathrm{~m}$ thick

8. Four informal magnetostratigraphic units

9. Conformably overlies Imnaha Basalt or overlies and intertongues with Picture Gorge Basalt; conformably and disconformably underlies Wanapum Basalt or disconformably underlies Saddle Mountains Basalt (both in Yakima Basalt Subgroup)

10. Type locality: Exposures on W-trending spur ridge extending from NW1/4 sec. 23 across N1/3 sec. 22 to NE1/4 sec. 21, T. 7 N., R. 46 E., lower Grande Ronde River Valley, Black Butte quadrangle, Asotin County, Wash.

Granger Mountain Member (Oquirrh Formation)

1. Early Permian (Wolfcampian)

2. Utah (C)

3. Baker, A. A., 1976, Geologic map of the west half of the Strawberry Valley quadrangle, Utah: U.S. Geol. Survey Misc. Inv. Ser. Map I-931, p. 2-3

4. Limy and silty sandstone interbedded with quartzite and limestone

5. Gray, weathers tan

6. $1,500 \mathrm{~m}$; range $1,500-2,200 \mathrm{~m}$

7. Wormlike trail markings, fusulinids

9. Overlies Wallsburg Ridge Member (Oquirrh Formation); underlies Kirkman Limestone

10. Type locality: On SE flank of Granger Mountain, extending along walls of Right Fork of Hobble Creek from mouth of Days Canyon to mouth of Cedar Canyon, NW1/4 sec. 34 to SW1/4 sec. 24, T. 7 S., R. 4 E., Utah County, Utah.

\section{Greenleaf Lake Limestone Member (McCully Formation)}

1. Middle Pennsylvanian (Morrowan)

2. Oklahoma (EC)

3. Sutherland, P. K., and Henry, T. W., 1977, Carbonate platform facies and new stratigraphic nomenclature of the Morrowan Series (Lower and Middle Pennsylvanian), northeastern Oklahoma: Geol. Soc. America Bull., v. 88, no. 3, p. 434

4. Limestone 
6. $6.4 \mathrm{~m}$, range $4.7-9.1 \mathrm{~m}$

7. Micritic and skeletal calcarenite (wackestone, packstone), fossiliferous

9. Conformably overlies informal shale "A" member (McCully Formation); underlies informal shale "B" member (McCully Formation), or unconformably underlies Atoka Formation

10. Type section: Measured Section 42, on bluff immediately E of Greenleaf Lake Dam, sec. 36, T. 14 N., R. 20 E., Muskogee County, Okla.

\section{Greenleaf Mountain Formation}

1. pre-Silurian (late Precambirian? to Ordovician?)

2. Massachusetts (C)

3. Bell, K. G., and Alvord, D. C., 1976, Pre-Silurian stratigraphy of northeastern Massachusetts: Geol. Soc. America Mem. 148 , p. 188-189, 202-203, app. 1 (in pocket)

4. Oligoclase-hornblende amphibolite

5. Dark-greenish-gray to dark-gray

-6. $225 \mathrm{~m}$

7. Fine-grained, thin-bedded, relict sedimentary structures

9. Unconformably overlies unnamed quartzites and gneisses and Middlesex Fells Volcanic Complex; underlies Burlington Formation

10. Type locality: Greenleaf Mountain, N Lexington quadrangle, Middlesex County, Mass.

Green Mountain Formation.

1. Early Proterozoic

2. Wyoming (SC)

3. Divis, A. F., 1976, Geology and geochemistry of Sierra Madre Range, Wyoming: Colorado School Mines Quart., v. 71, no. 3, p. 18-21

4. Metamorphosed calc-alkaline volcanic-sedimentary rocks including sericitic quartzite, marble, conglomerate, felsic and mafic schists

9. Overlies Archean quartz-biotite gneiss; overlies and intergrades with Big Creek Gneiss; intruded by Encampment River Granodiorite; underlies Libby Creek Group with structural unconformity

10. Type area: Exposures near Green Mountain, lat 41007'30" N., long $106^{\circ} 55^{\prime}$ W., Sierra Madre Range, Carbon County, Wyo.

Griffins Landing Sand Member (Dry Branch Formation)

1. Eocene, late

2. Georgia (EC)

3. Huddlestun, P. F., and Hetrick, J. H., 1979, The stratigraphy of the Barnwell Group of Georgia: Georgia Geol. Survey Open File Rept. 80-1, p. 24-25, 54-58

4. Calcareous sand with limestone and shell beds and clay lenses

6. $19.1 \mathrm{~m}$

7. Massive to rudely bedded, fossiliferous

9. Overlies Clinchfield Formation; interfingers with Twiggs Clay Member and Irwinton Sand Member (Dry Branch Formation); underlies Tobacco Road Sand; all units in Barnwell Group

10. Type locality: Exposure at Griffins Landing on Savannah River, $2.25 \mathrm{~km} \mathrm{~N}$ of junction of Griffins Landing Road and River Road, $8.4 \mathrm{~km} \mathrm{~N}$ of Girard, Burke County, Ga. 
Guild Mine Member (Mickey Pass Tuff)

1. Oligocene

2. Nevada (WC)

3. Proffett, J. M., Jr., and Proffett, B. H., 1976, Stratigraphy of the Tertiary ash-flow tuffs in the Yerington district, Nevada: Nevada Bur. Mines and Geology Rept. 27, p. $10-16$

4. Dacite, quartz latite, and rhyolite ash-flow tuff

5. Brown, pink, lavender

6. $790 \mathrm{~m}$, range $520-790 \mathrm{~m}$

7. Strongly welded, crystal-rich cooling unit

8. Unnamed map units $1,2,3$

9. Unconformably overlies unnamed early Tertiary rocks; underlies Weed Heights Member (map unit 6) or intervening unnamed map units 5 or 4 of Mickey Pass Tuff

10. Type area: Exposures $2 \mathrm{~km}$ SW of Guild Placer mines, Singatse Range, Lyon County, Nev.

Gushee Member (Penobscot Formation)

1. Ordovician

2. Maine (SE)

3. Bickel, C. E., 1976, Stratigraphy of the Belfast quadrangle, Maine: Geol. Soc. America Mem. 148, p. 116

4. Sulfidic anthophyllite-cordierite rock, amphibolite, quartzalbite granofels, minor mica schist

5. Weathers rusty or chalky

6. $500 \mathrm{~m}$

7. Coarse- to fine-grained; relict scoria and pillows in amphibolite

9. Belt of rocks in Penobscot Formation near its contact with Appleton Ridge Formation along St. George fault

10. Type area: Roland Gushee Farm, Appleton Township, Belfast quadrangle, Waldo County, Maine.

Haldane Bentonite Bed (Loves Park Member of Dunleith Formation)/

(Wall Member of Dunleith Formation)

1. Middle Ordovician

2. Illinois (NC)

3. Willman, H. B., and Kolata, D. R., 1978, The Platteville and Galena Groups in northern Illinois: Illinois Geol. Survey Circ. 502, p. 50

4. Bentonite clay

6. $0.05 \mathrm{~m}$

7. Bed marked by strong reentrant in exposures

9. In type section, overlies and underlies dolomite units in upper part of Loves Park Member; to W, in Galena, Ill., area, is in middle part of Wall Member

10. Type section: Victory School Section, abandoned quarry on $W$ side of Pine Creek, $N$ of Victory School, $3.2 \mathrm{~km} \mathrm{SW}$ of Mt. Morris, NW1/4SW1/4SE1/4 sec. 32, T. 24 N., R. 9 E., Ogle County, IIl. Named for town of Haldane, $8 \mathrm{~km} \mathrm{NW}$ of type section.

Hamburg Member (Leithsville Formation)

1. Early Cambrian

2. New Jersey (NC)

3. Markewicz, F. J., and Dalton, Richard, 1977, Stratigraphy and applied geology of the lower Paleozoic carbonates in 
northwestern New Jersey--Field Conference of Pennsylvania Geologists, 42d, Stroudsburg, 1977, Guidebook: [Harrisburg, Pennsylvania Geol. Survey] p. 13-14

4. Dolomite, shale, siltstone, sandstone

6. $29 \mathrm{~m}$

7. Rhythmically bedded cycles representative of mudflat to lagoonal environments

9. Overlies Califon Member; underlies Wallkill Member

10. Type section: Steep hillside, $0.4 \mathrm{~km} \mathrm{~S}$ of New Jersey Route $94,0.8 \mathrm{~km} \mathrm{~W}$ of Hamburg, Sussex County, N.J.

Happy Valley Branch Member (James Run Formation)

1. Paleozoic, early

2. Maryland (NE)

3. Higgins, M. W., 1977, Six new members of the James Run Formation, Cecil County, northeastern Maryland: U.S. Geol. Survey Bull. 1435-A, p. A127

4. Metamorphosed felsic volcaniclastic rocks with relict phenocrysts of sodic plagioclase and quartz

5. Light-gray to white

6. $915 \mathrm{~m}$

7. Fine-grained, medium- to thin-bedded

9. Overlies Gilpins Falls Member; probably partly equivalent to Big Elk Creek and Principio Creek Members

10. Type section: Exposed from just $\mathrm{N}$ of Happy Valley Branch, tributary of Susquehanna River, to contact with Gilpins Falls Member about 1,220 m NW of U.S. Highway I-95, Cecil County, Md.

\section{Harleyville Hember (Cooper Formation)}

1. Eocene, late(?) and Oligocene(?), early

2. South Carolina (C)

3. Ward, L. W., and others, 1979, Stratigraphic revision of Eocene, Oligocene, and lower Miocene formations of South Carolina: South Carolina Geol. Survey Geol. Notes, v. 23, no. 1, p. 18-23

4. Phosphatic, clayey calcarenite

5. Olive-gray, greenish-gray

6. $3 \mathrm{~m}$, range $3-30 \mathrm{~m}$

7. Compact, fine-grained, fossiliferous

9. Unconformably overlies Cross Member (Santee Limestone); unconformably underlies Parkers Ferry Member or Ashley Member (Cooper Formation)

10. Type section: Section at Giant Portland Cement Co. quarry, $3.2 \mathrm{~km} \mathrm{~N}$ of Harleyville, just $\mathrm{E}$ of Route 453, Ridgeville 15' quadrangle, Dorchester County, S.C. Named for nearby town of Harleyville.

Harmonyvale Member (Ontelaunee Formation)

1. Early Ordovician

2. New Jersey (NC)

3. Markewicz, F. J., and Dalton, Richard, 1977, Stratigraphy and applied geology of the lower Paleozoic carbonates in northwestern New Jersey--Field Conference of Pennsylvania Geologists, 42d, Stroudsburg, 1977, Guidebook: [Harrisburg, Pennsylvania Geol. Survey] p. 22-23

4. Dolomite, chert, limestone

5. Light-gray 
6. $>67 \mathrm{~m}$

7. Fine-grained to cryptocrystalline, stylolitic, fossiliferous

9. Overlies Beaver Run Member (Ontelaunee Formation); unconformably underlies Jacksonburg Formation

10. Type section: Not stated, although unit is described in measured sections. Probably named for Harmonyvale, a village about $5 \mathrm{~km}$ WSW of Hamburg, Sussex County, N.J.

\section{Harris Wash Tongue (Page Sandstone)}

1. Middle Jurassic (Bajocian)

2. Utah (SC)

3. Peterson, Fred, and Pipiringos, G. N., 1979, Stratigraphic relations of the Navajo Sandstone to Middle Jurassic formations in parts of southern Utah and northern Arizona: U.S. Geol. Survey Prof. Paper 1035-B, p. B27-B29

4. Sandstone

5. Gray to reddish-brown or grayish-red

6. $18.3 \mathrm{~m}$, range $<1-36.6 \mathrm{~m}$

7. Fine-grained, crossbedded, forms smooth cliff

9. Unconformably overlies Navajo Sandstone (Glen Canyon Group); underlies Judd Hollow Tongue (Carmel Formation of San Rafael Group), which separates it from Thousand Pockets Tongue (Page Sandstone)

10. Type section: W side Halfway Hollow, $0.8 \mathrm{~km}$ from junction with Harris Wash, $20 \mathrm{~km} \mathrm{SE}$ of Escalante, NE1/4SE1/4NE1/4 sec. 26, T. 36 S., R. 4 E., Garfield County, Utah.

Hart Ledge Complex (White Mountain Plutonic-Volcanic Series)

1. Jurassic and Cretaceous(?)

2. New Hampshire (C)

3. Henderson, D. M., and others, 1977, Geology of the Crawford Notch quadrangle, New Hampshire: Concord, New Hampshire Dept. Resources and Econ. Devel., p. 11

4. Syenite, quartz syenite, ferrorichterite granite, and riebeckite granite

5. Green, buff, white

7. Medium- to coarse-grained; circular and arcuate bodies of map-units form circular pluton $5 \mathrm{~km}$ across

8. Four informal lithologic map-units

9. Apparently intrudes, and may be younger than, Mount Osceola Granite (White Mountain Plutonic-Volcanic Series)

10. Type area: From Hart Ledge SW to Mount Tremont, Crawford Notch quadrangle, Grafton and Carroll Counties, N.H.

Harwood Member (Poplar River Formation)

1. Pleistocene (Wisconsinan)

2. North Dakota (EC)

3. Arndt, B. M., 1977, Stratigraphy of offshore sediment, Lake Agassiz--North Dakota: North Dakota Geol. Survey Rept. Inv. 60, p. 8

4. Clay

5. Gray, gray-brown

6. $1.8 \mathrm{~m}$

7. Mealy texture; fluvial-overbank deposits

9. Unconformably overlies Brenna Formation; conformably underlies West Fargo Member (Poplar River Formation) or unconformably underlies Sherack Formation

10. Type section: Boring T-18, North Dakota Geol. Survey test- 
hole, SW1/4SW1/4SW1/4 sec. 11, T. $147 \mathrm{~N} .$, R. 49 W., Traill County, N. Dak. Named for village of Harwood, Cass County.

\section{Hayfork Bally Heta-andesite}

1. Jurassic(?)

2. California (NW)

3. Irwin, W. P., 1977, Review of Paleozoic rocks of the Klamath Mountains: in Stewart, J. H., and others, eds., Paleozoic paleogeography of the western United States--Pacific Coast Paleogeography Symposium 1 [Bakersfield, Calif., 1977]: Los Angeles, Soc. Econ. Paleontologists and Mineralogists, Pacific Sec., p. 448

4. Meta-andesite

5. Light- to dark-gray-green

6. $>1,000 \mathrm{~m}$

7. Fine-grained groundmass, bedded, forms blocky outcrops and light-colored soil; lowest unit of Hayfork terrane

9. Intruded by Jurassic Ironside Mountain batholith and Wildwood pluton; structurally underlies middle unit of Hayfork terrane, or unconformably underlies cretaceous or Tertiary rocks

10. Type locality: Exposures along main Forest Service road that crosses $N$ slope of Hayfork Bally at altitude of $1,200-$ $1,370 \mathrm{~m}$, secs. 27 and 28, T. $33 \mathrm{~N} .$, R. $12 \mathrm{E}$., and along branch of that road that climbs $\mathrm{N}$ and $\mathrm{W}$ slopes of peak to lookout tower, Hayfork quadrangle, Trinity County, Calif.

\section{Haywood Landing Member (Belgrade Formation)}

1. Miocene, early

2. North Carolina (EC)

3. Ward, L. W., Lawrence, D. R., and Blackwelder, B. W., 1978, Stratigraphic revision of the middle Eocene, Oligocene, and lower Miocene--Atlantic Coastal Plain of North Carolina: U.S. Geol. Survey Bull. 1457-F, p. F15-F16

4. Phosphatic, calcareous, clayey, shelly quartz sand

5. Gray to brown

6. $3 \mathrm{~m}$, range $3-31 \mathrm{~m}$

7. Unconsolidated; offshore equivalent of nearshore Pollocksville Member

9. Unconformably overlies River Bend Formation; unconformably underlies Duplin Formation

10. Type locality: Outcrop at Haywood Landing, L bank of White Oak River, $1.2 \mathrm{~km}$ below mouth of Holston Creek, Jones County, N.C.

Hickory Hills Till Member (Wolf Creek Formation)

1. Pleistocene (pre-Wisconsinan)

2. Iowa (C)

3. Hallberg, G. R., 1980, Pleistocene stratigraphy in eastcentral Iowa: Iowa Geol. Survey Tech. Inf. Ser., no. 10, p. 14-37

4. Sandy till, pebble loam

5. Yellowish-brown to dark-gray

6. $16.5 \mathrm{~m}$

7. Loam-textured till

9. Unconformably overlies informal Dysart paleosol or Aurora Till Member; as the upper unit of Wolf Creek Formation, unconformably underlies late Sangamon pedisediment 
10. Type section: 402 roadcut and core section, Hickory Hills Park, on $W$ end of Caseys Paha, where State Highway 21 cuts through paha, NW1/4SE1/4 sec. 10, T. 86 N., R. 13 W., Tama County, Iowa.

High Lake Member (Laketown Dolostone)

1. Early Silurian

2. Utah (NC), Nevada

3. Budge, D. R., and Sheehan, P. M., 1980, The Upper Ordovician through Middle Silurian of the eastern Great Basin--Pt. 1, Introduction--historical perspective and stratigraphic synthesis; Pt. 2, Lithologic descriptions: Milwaukee Public Mus. Contr. Biology and Geology, no. 28, p. 19 (pt. 1); no. 29 , p. 6 (pt. 2)

4. Dolomite with chert seams and nodules

5. Gray

6. $105 \mathrm{~m}$

7. Finely to coarsely crystalline, medium- to thick-bedded, lenticular, laminated

9. Overlies Tony Grove Lake Member; underlies Portage Canyon Member, as at type section, or Gettel Member

10. Type section: SW $1 / 4$ SW $1 / 4$ sec. 5 , T. 13 N., R. 3 E., Tony Grove Lake, Bear River Range, Cache County, Utah. Derivation of name not stated.

Hoko River Formation (Twin River Group)

1. Eocene, late (Narizian)

2. Washington (NW)

3. Snavely, P. D., Jr., Niem, A. R., and Pearl, J. E., 1978, Twin River Group (upper Eocene to lower Miocene)--defined to include the Hoko River, Makah, and Pysht Formations, Clallam County, Washington: U.S. Geol. Survey Bull. 1457-A, p. A111-A 115

4. Siltstone, with interbeds of phyllitic and basaltic sandstone, pebbly sandstone, and conglomerate

6. $1,600 \mathrm{~m}$, range $1,600-2,300 \mathrm{~m}$

7. Thin-bedded to massive siltstone; conglomerate and sandstone channels; calcareous concretions; fossiliferous

9. Conformably overlies, or intertongues with, Lyre Formation; gradationally, or locally unconformably, underlies Makah Formation (Twin River Group)

10. Type locality: Exposures in stream bed and cliffs of Hoko River and in railway and road cuts parallel to river from point $1 \mathrm{~km} \mathrm{~N}$ of junction of Blue Canyon with Hoko River $S$ to point $1.5 \mathrm{~km} \mathrm{~N}$ of Hoko Falls bridge, NW Olympic Peninsula, Clallam County, Wash.

Hollofield Layered Ultramafite (Baltimore Mafic Complex)

1. Cambrian(?)

2. Maryland (NC)

3. Crowley, W. P., 1976, The geology of the crystalline rocks near Baltimore and its bearing on the evolution of the eastern Maryland Piedmont: Maryland Geol. Survey Rept. Inv. 27, p. 13-14, 28-30

4. Actinofels and actinoschist interlayered with amphibolite and serpentinite

5. Green

9. In thrust-fault contact with Loch Raven Schist, Della and 
Sykesville Formations (Wissahickon Group); underlies Mount Washington Amphibolite (Baltimore Mafic Complex) in $\mathrm{E}-\mathrm{W}$ anticline which is truncated on SE by James River Formation

10. Type locality: Exposures at abandoned Hollofield Quarry along $\mathrm{E}$ bank of Patapsco River, $80 \mathrm{~m} \mathrm{~S}$ of first bridge crossing the Patapsco $N$ of U.S. Highway I-7Q, Ellicott City quadrangle, Howard County, Md.

Holly Corner Gneiss (Fredericksburg Complex)

1. Early Cambrian(?)

2. Virginia (EC)

3. Pavlides, Louis, 1980, Revised nomenclature and stratigraphic relationships of the Fredericksburg Complex and Quantico Formation of the Virginia Piedmont: U.S. Geol. Survey Prof. Paper 1146, p. 5, 7

4. Amphibole-biotite gneiss

5. Dark-gray to black

7. Fine- to medium-grained, foliated; refolded synform struc-

- ture

9. Allochthonous equivalent of Ta River Metamorphic Suite and possibly an eastern distal facies of Chopawamsic Formation; intruded by Falls Run Granite Gneiss

10. Type area: Along two intermittent streams that flow into Rappahannock River, $S$ of Holly Corner crossroads, NC Salem Church quadrangle, Stafford County, Va.

Home Station Member (Augusta Mountain Formation)

1. Middle Triassic (Ladinian)

2. Nevada (NC)

3. Nichols, K. M., and Silberling, N. J., 1977, Stratigraphy and depositional history of the Star Peak Group (Triassic), northwestern Nevada: Geol. Soc. America Spec. Paper 178, p. 23-25

4. Interstratified primary dolomite, limestone, sandstone, and secondary dolomite

5. Light-gray

6. $250 \mathrm{~m}$

7. Massive, saccharoidal, cliff-forming, supratidal deposits

9. Disconformably overlies Fossil Hill Member (Favret Formation); transitionally underlies Panther Canyon Member (Augusta Mountain Formation) (both formations in Star Peak Group)

10. Type section: Ridge $S$ of Favret Canyon, T. 25 N., R. 39 E., N Augusta Mountains, Pershing County, Nev. Named for Home Station Ranch, $30 \mathrm{~km}$ NW of type section.

Hominy Peak Formation (Absaroka Volcanic Supergroup)

1. Eocene, middle

2. Wyoming (NW)

3. Love, J. D., Leopold, E. B., and Love, D. W., 1978, Eocene rocks, fossils, and geologic history, Teton Range, northwestern Wyoming: U.S. Geol. Survey Prof. Paper 932-B, p. 331

4. Volcaniclastic conglomerates, tuffs, quartzite conglomerates, andesite flows and breccia

5. Green, brown, red

6. $610 \mathrm{~m}$

7. Minor gold deposits; fossiliferous (pollen) 
9. Unconformably overlies Pinyon Conglomerate or older rocks; unconformably underlies Conant Creek Tuff (at type section) or Huckleberry Ridge Tuff; intruded by late Eocene dacite porphyry of Birch Hills

10. Type section: Exposures $0.8 \mathrm{~km} \mathrm{~S}$ of Hominy Peak on SEfacing escarpment of Hominy Ridge on NW margin of Conant basin, SE1/4 sec. 16 and N1/2 sec. 21, T. 47 N., R. 117 W., Grassy Lake Reservoir quadrangle, Teton County, Wyo.

Honey Formation (Packsaddle Group)

1. Precambrian

2. Texas (C)

3. McGehee, R. V., 1979, Precambrian rocks of the southeastern Llano region, Texas: Texas Bur. Econ. Geology Geol. Circ. $79-3$, p. 8-9

4. Graphite schist, calc-silicate rock, marble

6. 2,530 m (composite)

9. Overlies Valley Spring Gneiss (Llano Supergroup); underlies Sandy Formation (Packsaddle Group). Unit was formerly Honey Creek Member (Packsaddle Formation) of McGehee (1964)

10. Type locality: Base exposed in Honey Creek, NW of Packsaddle Mountain, Cap Mountain quadrangle; upper part exposed along Sandy Creek from State Highway 71 bridge to mouth of creek, Dunman Mountain quadrangle, Llano County, Tex.

Hook Mountain Basalt (Newark Supergroup)

1. Early Jurassic

2. New Jersey (NE)

3. Olsen, P. E., 1980, The latest Triassic and Early Jurassic formations of the Newark Basin (eastern North America, Newark Supergroup)--stratigraphy, structure, and correlation: New Jersey Acad. Sci. Bull., v. 25, no. 2, p. 37-38

4. Two massive basalt flows with interbedded thin pahoehoe flows

6. $110 \mathrm{~m}$

9. Overlies Towaco Formation; underlies Boonton Formation. Unit was formerly "third" Watchung Basalt of Darton (1890)

10. Type section: Cuts along Hook Mountain Road and U.S. Interstate Highway 80 through $S$ terminus of Hook Mountain near Pine Brook, Morris County, N.J.

Hope Member (Rickenbach Formation)

1. Early Ordovician

2. New Jersey (NC)

3. Markewicz, F. J., and Dalton, Richard, 1977, Stratigraphy and applied geology of the lower Paleozoic carbonates in northwestern New Jersey--Field Conference of Pennsylvania Geologists, 42d, Stroudsburg, 1977, Guidebook: [Harrisburg, Pennsylvania Geol. Survey] p. 17

4. Dolomite with chert beds

5. Gray to dark-gray

6. $51 \mathrm{~m}$

7. Aphanitic to coarsely crystalline, medium- to massivebedded, with internal brecciation

9. Overlies lower member of Rickenbach Formation; underlies Branchville Member (Epler Formation); intertongues with informal Crooked Swamp dolomite facies (Rickenbach Formation), which is well developed $\mathrm{N}$ of Lafayette, Sussex 
County, N.J.

10. Type section: On U.S. Highway I-80 near New Jersey County Route 521 exit, N of Hope, Warren County, N.J.

Hopukani Formation (Hamakua Group)

1. Pleistocene

2. Hawaii (SE)

3. Porter, S. C., 1979, Quaternary stratigraphy and chronology of Mauna Kea, Hawaii--a 380,000-yr record of mid-Pacific volcanism and ice-cap glaciation: Geol. Soc. America Bull. (pt. 2, microfiche), v. 90, no. 7, p. 988-998

4. Alkalic olivine basalt lava with olivine phenocrysts

6. $30 \mathrm{~m}$

7. Thin-bedded vesicular pahoehoe flows and cinder cones

9. Overlies volcanic rocks of Hamakua Group (lower member of Hamakua volcanic series of Stearns and Macdonald (1946), not renamed here); underlies Pohakuloa Formation (Hamakua Group) or basal lavas of Laupahoehoe Group. Equivalent to upper member of Hamakua volcanic series of Stearns and Macdonald (1946)

10. Type section: Along State Highway 19 on $S$ wall of Laupahoehoe Gulch, between 100 and $130 \mathrm{~m}$ altitude, Mauna Kea volcano, Hawaii County, Hawaii. Named for nearby Hopukani Springs.

Horseshoe Formation

1. Late Cretaceous

2. Idaho (SE)

3. Entzminger, D. J., 1979, Revision of Upper Cretaceous stratigraphy--Big Hole Mountains, Idaho: Earth Sci. Bull., v. 12 , no. 4, p. 20-22

4. Sandstone, shale, coal

5. Brown, gray, green

6. Range $340-400 \mathrm{~m}$

7. Persistent fossil bed (mollusk fragments)

8. In western coal belt, informal subdivisions include twelve named coal beds and Brown Bear leader sandstone, the lowest massive sandstone bed

9. Gradationally overlies Bacon Ridge Formation; underlies unnamed unit

10. Composite section: Compiled from four sections in Horseshoe Creek area, including measured surface section on ridge $\mathrm{N}$ of Horseshoe Creek and two subsurface sections from Phillips Horseshoe No. 1 well and Sunmark-Supron Miner Estate 4-34 well, T. 5 N., R. 44 E., Big Hole Mountains, Garns Mountain quadrangle, Teton County, Idaho.

Hoyt Canyon Formation

1. Late Triassic

2. Nevada (WC)

3. Speed, R. C., 1976, Geologic map of the Humboldt lopolith and surrounding terrane, Nevada: Geol. Soc. America Map and Chart Ser. MC-14, p. 2

4. Alternating micritic limestone and slaty silty mudstone, siltstone, and minor sandstone

5. Black

6. $500 \mathrm{~m}$

7. Thin-bedded 
9. Conformably overlies Bernice Formation; conformably underlies Mud Springs Canyon Formation

10. Type locality: Not stated. Probably named for exposures in Hoyt Canyon, secs. 10 and 11, T. 22 N., R. 37 E., Clan Alpine Mountains, Churchill County, Nev.

Huber Formation

1. Paleocene and Eocene, early(?) and middle

2. Georgia (C)

3. Buie, B. F., 1978, The Huber Formation of eastern central Georgia: Georgia Geol. Survey Bull. 93, p. 1-7

4. Sand and kaolin with bauxite beds

5. White to cream, buff, gray

6. $\quad 10.2 \mathrm{~m}$, range $<1-28.7 \mathrm{~m}$

7. Sand medium- to very coarse grained, crossbedded; kaolin in beds, tubular forms, and balls; fossiliferous

9. Unconformably overlies undifferentiated Cretaceous strata; unconformably underlies Clinchfield Sand, Tivola Limestone, or Barnwell Formation

10. Type locality: Exposures from vicinity of Dry Branch and Stone Creek Church, SE for $8 \mathrm{~km}$ to Flat Creek, Twiggs County, Ga. Named for Huber Post office.

Huntington Formation

1. Late Triassic

2. Oregon (EC)

3. Brooks, H. C., 1979, Geologic map of the Huntington and part of the Olds Ferry quadrangles, Baker and Malheur Counties, Oregon: Oregon Dept. Geology and Mineral Industries Geol: Map Ser. GMS-13

4. Volcanic agglomerate, tuff, and flows intercalated with coarse volcaniclastic breccia and conglomerate and minor sedimentary rocks

6. Range 3,000->6,000 m

7. Bedded sequences of fine-grained sedimentary rocks; shallow intrusive bodies; zeolite and greenschist facies, abundant structural disruptions; fossiliferous (ammonites)

9. Unconformably underlies Jet Creek Member (Weatherby Formation); base not exposed

10. Type locality: Along Burnt River and Snake River, Tps. 13 and 14 S., Rs. 44 and 45 E., Baker County, Oreg. Named for town in EC Huntington quadrangle.

Huntley Mountain Formation

1. Late Devonian and Early Mississippian

2. Pennsylvania (NC)

3. Berg, T. M., and Edmunds, W. E., 1979, The Huntley Mountain Formation--Catskill-to-Burgoon transition in north-central Pennsylvania: Pennsylvania Geol. Survey, 4 th ser., Inf. Circ. 83 , p. $1-80$

4. Sandstone, with minor siltstone, shale, and conglomerate

5. Greenish-gray to light-olive-gray

6. $170 \mathrm{~m}$

7. Nonmarine clastic succession; fining-upward cycles in lower part; crossbedded

9. Transitionally overlies Catskill Formation; transitionally underlies Burgoon Sandstone

10. Type section: Exposure on SE slope of Huntley Mountain, NW 
of village of Waterville, between lat $41^{\circ} 19^{\prime} 09^{\prime \prime} \mathrm{N}$. , long $77^{\circ} 22^{\prime} 20^{\prime \prime} \mathrm{W}$. (top) and lat $41^{\circ} 18^{\prime} 35^{\prime \prime} \mathrm{N}$. , long $77^{\circ} 21^{\prime} 19^{\prime \prime} \mathrm{W}$. (base), Waterville quadrangle, Lycoming County, Pa.

\section{Hu-pwi Rhyodacite}

\section{Miocene}

2. Nevada (WC)

3. Ekren, E. B., and others, 1980, Stratigraphy, preliminary petrology, and some structural features of Tertiary volcanic rocks in the Gabbs Valley and Gillis Ranges, Mineral County, Nevada: U.S. Geol. Survey Bull. 1464, p. 36-41

4. Rhyodacite tuff and lava, flow breccia

5. Gray, brown, black

6. >1,000 m

7. Porphyritic, cooling units

8. Nugent Tuff Member, Ghost Dance Lava Member, informal intermediate lavas of Poinsettia Spring area probably coeval with Ghost Dance, and Poinsettia Tuff Member

9. Overlies Blue Sphinx Tuff or lava of Nugent Wash; underlies lava of Mount Ferguson or tuff of Copper Mountain

10. Type locality: Exposures near Hu-pwi Wash, T. 12 N., R. 30 E., N Gillis Range, Mineral County, Nev.

Hyak Member (Lakedale Drift)

1. Pleistocene

2. Washington (C)

3. Porter, S. C., 1976, Pleistocene glaciation in the southern part of the North Cascade Range, Washington: Geol. Soc. America Bull. v. 87 , no. 1, p. 71

4. Till, lacustrine sediments

7. Moraines, outwash fill

8. Till and outwash facies

9. Overlies Domerie Member (Lakedale Drift); underlies Holocene alluvium

10. Type locality: Till facies: roadcuts along U.S. Highway I-90, NW1/4NW1/4 sec. 15, T. 22 N., R. 11 E.; outwash facies: cutbank along Coal Creek near town of Hyak, NW1/4SE1/4 sec. 15, T. 22 N., R. 11 E., Kittitas County, Wash.

Hydes Marble Member (Loch Raven Schist)

1. Cambrian-Ordovician(?)

2. Maryland (NC)

3. Crowley, W. P., 1976, The geology of the crystalline rocks near Baltimore and its bearing on the evolution of the eastern Maryland Piedmont: Maryland Geol. Survey Rept. Inv. 27, p. 10,24

4. Metalimestone, metadolostone, calc-silicate fels

5. White

6. Range $<1-300 \mathrm{~m}$

9. Lens within main body of Loch Raven Schist

10. Type locality: Not established because of paucity of outcrop and heterogeneous nature of rock types. Named for village of Hydes, EC Baltimore County, Md.

Ibex Member (Ely Springs Dolostone)

1. Late Ordovician

2. Utah (WC), Nevada 
3. Budge, D. R., and Sheehan, P. M., 1980, The Upper Ordovician through Middle Silurian of the eastern Great Basin--Pt. 1, Introduction--historical perspective and stratigraphic synthesis; Pt. 2, Lithologic descriptions: Milwaukee Public Mus. Contr. Biology and Geology, no. 28, p. 13-15 (pt. 1); no. 29, p. 22 (pt. 2)

4. Dolomite containing frosted quartz sand grains

5. Grayish-black, gray, brownish-black

6. $9.5 \mathrm{~m}$

7. Microcrystalline to finely crystalline, thin- to thickbedded

9. Underlies Barn Hills Member (Ely Springs Dolostone); overlies Eureka Quartzite

10. Exposures $3.2 \mathrm{~km}$ NNW of Ibex Well bench mark 4779, SE1/4NW1/4 sec. 26, T. 21 S., R. 14 W., Barn Hills, Confusion Range, Millard County, Utah.

Ice Harbor Member (Saddle Mountains Basalt)

1. Miocene, late

2. Washington (SE)

3. Swanson, D. A., and others, 1979, Revisions in stratigraphic nomenclature of the Columbia River Basalt Group: U.S. Geol. Survey Bull. 1457-G, p. G51-G53

4. Basalt

6. Range $15-30 \mathrm{~m}$

7. At least three thick flows, with thin flows and tephra

8. Informal basalt of Basin City, basalt of Martindale, and basalt of Goose Island

9. Unconformably overlies Elephant Mountain Member; underlies alluvial deposits; apparently older than Lower Monumental Member

10. Type locality: Abandoned quarry on $S$ side of Snake River $2.6 \mathrm{~km} \mathrm{~W}$ of Ice Harbor Dam, SE1/4SE1/4 sec. 22, T. $9 \mathrm{~N}$., R. 31 E., Humorist quadrangle, Walla Walla County, Wash.

Imnaha Basalt (Columbia River Basalt Group)

1. Miocene, early

2. Oregon (NE), Idaho, Washington

3. Swanson, D. A., and others, 1979, Revisions in stratigraphic nomenclature of the Columbia River Basalt Group: U.S. Geol. Survey Bull. 1457-G, p. G8-G12

4. Plagioclase-phyric basalt

6. $500 \mathrm{~m}$

7. Coarse-grained, 14 flows, weathers to grus-covered slopes

9. Unconformably overlies pre-Tertiary rocks; conformably underlies Grande Ronde Basalt (Yakima Basalt Subgroup of Columbia River Basalt Group)

10. Type locality: Exposures in cliffs on $W$ side of Snake River above $N$ end of Dug Bar, near mouth of Imnaha River, Cactus Mountain quadrangle, Wallowa County, Oreg.

Indian John Member (Kittitas Drift)

1. Pleistocene

2. Washington (C)

3. Porter, S. C., 1976, Pleistocene glaciation in the southern part of the North Cascade Range, Washington: Geol. Soc.

America Bull., v. 87, no. 1, p. 67-69

4. Gravel, till 

6. $100 \mathrm{~m}$
7. Moraines, outwash
8. Till and outwash facies
9. Overlies Swauk Prairie Member (Kittitas Drift); underlies Lakedale Drift
10. Type locality: Till facies: side of Indian John Hill at $635 \mathrm{~m}$ alt., NW1/4SW1/4 sec. 3, T. $19 \mathrm{~N} .$, R. $16 \mathrm{E}$. , outwash facies: borrow pit on $\mathrm{N}$ side of Indian John Hill, NW1/4SE1/4 sec. 3, T. 19 N., R. 16 E., upper Yakima River drainage basin, Kittitas County, Wash.

\section{Indian Well Formation}
1. Oligocene
2. Nevada (NE)
3. Smith, J. F., Jr., and Ketner, K. B., 1976, Stratigraphy of post-Paleozoic rocks and summary of resources in the Carlin- Pinon Range area, Nevada: U.S. Geol. Survey Prof. Paper $867-\mathrm{B}$, p. B23-B28
4. Tuffaceous sandstone, limestone, and conglomerate, tuff, and ash-flow tuff
5. Tan, gray, white
6. $1,015 \mathrm{~m}$
7. Interlayered; sedimentary rocks of lacustrine and fluviatile origin
8. Four informal units
9. Unconformably overlies older Tertiary (including Elko Forma- tion), Jurassic, and Paleozoic rocks; unconformably under- lies Quaternary alluvium or locally underlies younger Tertiary rocks (including Humboldt Formation)
10. Composite type section: Secs: 2 and 3, T. 30 N., R. 54 E., sec. 25, T. 31 N., R. 54 E., and secs. 29 and 30, T. 31 N., R. 55 E., Dixie Flats quadrangle, Elko County, Nev. Named for a water well in $\mathrm{SE} 1 / 4 \mathrm{sec} .30, \mathrm{~T} .31 \mathrm{~N} ., \mathrm{R} .55 \mathrm{E}$.

\section{Intracoastal Formation}

1. Miocene, middle, to Pliocene, late

2. Florida (NW)

3. Schmidt, Walter, and Clark, M. W., 1980, Geology of Bay County, Florida: Florida Bur. Geology Bull. 57, p. 44-54

4. Argillaceous, calcarenitic, sandy limestone

5. Gray, olive-green

6. $49 \mathrm{~m}$, range $<1-73 \mathrm{~m}$

7. Poorly consolidated, microfossiliferous, subsurface; missing biostratigraphic zones indicate late Miocene-early Pliocene hiatus

9. Unconformably overlies Bruce Creek Limestone; underlies or interfingers with Jackson Bluff Formation or unconformably underlies Pliocene to Holocene sands

10. Type section: Intracoastal Waterway core No. 1 (W-8873), depth-interval 20-69 m, NE1/4SW1/4 sec. 11, T. $3 \mathrm{~S}$. , R. 18 w., Walton County, Fla.

\section{Intricate Basalt}

1. Pliocene(?)

2. Alaska (C)

3. Detterman, R. L., and Reed, B. L., 1980, Stratigraphy, structure, and economic geology of the Iliamna quadrangle, Alaska: U.S. Geol. Survey Bull. 1368-B, p. B58-B59 
4. Olivine-augite basalt

5. Black to dark-green

6. Range 100-150 m

7. Glassy to porphyritic, columnar jointing

9. Disconformably to unconformably overlies Gibraltar Lake Tuff and all other Tertiary rocks; underlies Quaternary surficial deposits

10. Type locality: Exposures around Intricate Bay, at SE end of Iliamna Lake, Iliamna quadrangle, Alaska Peninsula, Alaska.

\section{Ironshire Formation}

1. Pleistocene (Sangamonian)

2. Maryland (SE), Delaware, Virginia

3. Owens, J. P., and Denny, C. S., 1979, Upper Cenozoic deposits of the central Delmarva Peninsula, Maryland and Delaware: U.S. Geol. Survey Prof. Paper 1067-A, p. A20-A22

4. Sand, gravelly sand

5. Pale-yellow to white, with layers of black minerals

6. $7.6 \mathrm{~m}$, range $<7-33 \mathrm{~m}$

7. Coarsens upward; crossbedded, fluviatile-estuarine channel fill and beach sand

9. Unconformably overlies Beaverdam Sand or Omar Formation against E-facing scarp

10. Type locality: Borrow pits near Ironshire, Delmarva Peninsula, Worcester County, Md.

Jabez Sandstone Member (Fort Payne Formation)

1. Early Mississippian

2. Kentucky (SC)

3. Kepferle, R. C., and others, 1980, Jabez Sandstone Member--a new member of the Fort Payne Formation (Mississippian), south-central Kentucky: U.S. Geol. Survey Bull. 1502-A, p. A 104-A 107

4. Sandstone

5. Gray to yellowish-gray, weathers brownish red

6. $43 \mathrm{~m} \max$

7. Medium-grained, angular, well-sorted, planar-bedded, NWtrending prism of vertically stacked coalescing tongues

9. Overlies and intercalated with limestone and dolosiltite of lower part of Fort Payne Formation; intercalated with Cane Valley Limestone Member (Fort Payne Formation); underlies Salem and Warsaw Formations

10. Type section: $S$ shore of Lake Cumberland near mouth of Harmon Creek, lat $36^{\circ} 55^{\prime} 20^{\prime \prime} \mathrm{N}$., long $84^{\circ} 57^{\prime} 15^{\prime \prime}$ W., Jabez quadrangle, Wayne County, Ky. Named for exposures $6.5 \mathrm{~km} \mathrm{SW}$ of town of Jabez.

Jam Brook Formation

1. Cambrian or Ordovician

2. Maine (SC)

3. Bickel, C. E., 1976, Stratigraphy of the Belfast quadrangle, Maine: Geol. Soc. America Mem. 148, p. 116-119

4. Quartz-mica schist; calc-silicate gneiss, schist, and phyllite; quartzite; quartz-pebble metaconglomerate; marble

6. $\leq 1,000 \mathrm{~m}$

7. Marine transgressive sequence

8. Five informal map units reflecting lithology

9. In fault contact with Penobscot Formation to SE along 
inferred thrust, and with Appleton Ridge Formation to NW along St. George fault. Unit was formerly informal St. George Formation of Cheney (1967)

10. Type area: Jam Brook, SW Belfast quadrangle, Waldo County, Maine.

\section{Jansen Creek Member (Makah Formation)}

1. Oligocene, early

2. Washington (NW)

3. Snavely, P. D., Jr., and others, 1980, Makah Formation--a deep-marginal-basin sequence of late Eocene and Oligocene age in the northwestern Olympic Peninsula, Washington: U.S. Geol. Survey Prof. Paper 1162-B, p. 14-15

4. Basaltic sandstone and conglomerate

6. $200 \mathrm{~m}$

7. Deformed, thick-bedded, fossiliferous, shallow-water olistostrome deposits, cliff-forming

9. Lies $250 \mathrm{~m}$ above Third Beach Member; overlies and underlies, with sharp contacts, unnamed undeformed deep-water marine strata of Makah Formation

10. Type section: Sea cliffs, wave-cut platforms, and sea stacks from headland $0.5 \mathrm{~km}$ E of Bullman Creek to point 0.7 $\mathrm{km}$ SE of Brush Point, NE1/4NW1/4 sec. 6, T. $32 \mathrm{~N} ., \mathrm{R}, 13 \mathrm{~W}$. , Strait of Juan de Fuca, Clallam County, Wash. Named for exposures at mouth of Jansen Creek, SE1/4SE1/4 sec. 26, T. $33 \mathrm{~N} .$, R. $14 \mathrm{~W}$.

Jaycox Shale Member (Ludlowville Formation)

1. Middle Devonian

2. New York (WC)

3. Baird, G. C., 1979, Sedimentary relationships of Portland Point and associated Middle Devonian rocks in central and western New York: New York State Mus. Bull. 433, p. 14-19, 23

4. Calcareous shale with basal muddy limestone

5. Light-colored, gray

6. $\quad 3.6 \mathrm{~m}$, range $0.48-16.00 \mathrm{~m}$

7. Fossiliferous

9. Equivalent to upper part of King Ferry Shale Member (Ludlowville Formation) E of Seneca Lake; overlies Wanakah Shale Member (Ludlowville Formation); paraconformably underlies Tichenor Limestone Member (Moscow Formation)

10. Type section: Exposures in three waterfalls and banks along $\mathrm{S}$ branch of Jaycox Creek, $3.2 \mathrm{~km}$ NNE of Geneseo and $400 \mathrm{~m} \mathrm{~W}$ of New York Route 39, Geneseo quadrangle, Livingston County, N.Y.

Jemtland Formation (Perham Group)

1. Silurian (late Wenlockian and early Ludlovian)

2. Maine (NE)

3. Roy, D. C., and Mencher, Ely, 1976, Ordovician and Silurian stratigraphy of northeastern Aroostook County, Maine: Geol. Soc. America Mem. 148 , p. 39-41, 50

4. Interlayered silty shale, shale, and calcareous and lithic graywacke

6. Range $610-850 \mathrm{~m}$

7. Fine- to coarse-grained, thin-bedded

9. Conformably overlies Frenchville Formation and New Sweden 
Formation (Perham Group); conformably underlies Fogelin Hill Formation

10. Type area: Exposures along Maine Route 161 in Jemtland, Aroostook County, Maine.

Jericho Run Member (Beaufort Formation)

1. Paleocene, early (Danian)

2. North Carolina (EC)

3. Brown, P. M., and others, 1977, Wrench-style deformation in rocks of Cretaceous and Paleocene age, North Carolina coastal plain: North Carolina Div. Earth Resources Spec. Pub. 5, p. 13-14, 39-40

4. Siliceous mudstone with basal conglomerate and chert and sandstone layers

5. Black to gray

6. Range $0.9-2.7 \mathrm{~m}$

7. Friable to extremely hard; silicified microfossils poorly preserved

9. Disconformably overlies Peedee Formation; unconformably underlies surficial material

10. Type locality: Locality NC-LEN-0-8-73, exposures at and upstream from waterfall (on Jericho Run, tributary to Neuse River), in ravine extending back from Jericho Run fault scarp, $0.8 \mathrm{~km} \mathrm{NE}$ of County Road 1809 (lat $35^{\circ} 19^{\prime} 14^{\prime \prime} \mathrm{N}$. , long $77^{\circ} 29^{\prime} 43^{\prime \prime}$ W.) near Graingers, Lenoir County, N.C.

Jet Creek Member (Weatherby Formation)

1. Early Jurassic

2. Oregon (EC)

3. Brooks, H. C., 1979, Geologic map of the Huntington and part of the Olds Ferry quadrangles, Baker and Malheur Counties, Oregon: Oregon Dept. Geology and Mineral Industries Geol. Map Ser. GMS-13

4. Pebble and cobble conglomerate, wacke, siltstone, limestone

5. Red, green

6. $250 \mathrm{~m}$

7. Conglomerate composed of volcanic fragments; limestone, massive and thin-bedded; fossiliferous (ammonites)

9. Unconformably overlies Huntington Formation; intergrades laterally with lower part of Weatherby Formation; upper and lower contacts obscured by landsliding

10. Type section: Exposures near head of Jet [Jett on base map] Creek in secs. 16, 17, 18, 19, and 20, T. 13 S., R. 45 E., Baker County, Oreg.

Jewell Bluff Formation (Stones River Group)

1. Middle Ordovician

2. Tennessee (SC)

3. Wilson, R. L., 1979, The stratigraphy of exposed rocks in Hamilton County, Tennessee: Tennessee Div. Geology Bull. 79, p. 23-25

4. Limestone, siltstone

5. Gray, greenish-gray, reddish-gray

6. $104 \mathrm{~m}$

7. Thin- to medium-bedded

8. Informal lower and upper members

9. Unconformably overlies Mascot Dolomite (Knox Group); conformably underlies Carters Limestone (Stones River Group) 
10. Type section: Exposures in Jewell Bluff, on $\mathbf{N}$ side of Hiwassee River across from mouth of Gunstocker Creek, Meigs County, Tenn.

Johnson Member (Snake Creek Formation)

1. Miocene, late

2. Nebraska (NW)

3. Skinner, M. F., Skinner, S. M., and Gooris, R. J., 1977, Stratigraphy and biostratigraphy of late Cenozoic deposits in central Sioux County, western Nebraska: Am. Mus. Nat. History Bull., v. 158, art. 5, p. 311-314

4. Sand and gravel with sedimentary and granite clasts in lower part, sand and clay in upper part

6. $21 \mathrm{~m}$; range $2-21 \mathrm{~m}$

7. Unconsolidated, stream-channel deposits, fossiliferous (vertebrates)

9. Overlies Sheep Creek Formation (Hemingford Group) with erosional unconformity, or locally overlies slump blocks of Murphy Member; uppermost member of Snake Creek Formation (Ogallala Group); underlies sand and sod at surface

10. Type section: Near head of East Pliohippus Draw, NE1/4NW1/4 sec. 32, and SE1/4SW1/4 sec. 29, T. 26 N., R. 55 W., Sioux County, Nebr. Named for Vance Johnson Ranch.

Jones Falls Schist

1. Cambrian(?)

2. Maryland (NC)

3. Crowley, W. P., 1976, The geology of the crystalline rocks near Baltimore and its bearing on the evolution of the eastern Maryland Piedmont: Maryland Geol. Survey Rept. Inv. 27, p. 13,15

4. Biotite-plagioclase-muscovite-quartz schist

6. Range $<1-250 \mathrm{~m}$

7. Medium- to coarse-grained

9. Overlies Relay Gneiss Member, Carroll Gneiss Member, or Druid Hill Amphibolite Member (James Run Formation) in NE-SW syncline

10. Type locality: Outcrops along Jones Falls, E of Druid Hill Park between Falls Road and 28 th Street ramps onto Jones Falls Expressway, Baltimore City, Baltimore County, Md.

Joy Tuff

1. Eocene, late, and oligocene, early

2. Utah (WC)

3. Lindsey, D. A., 1979, Geologic map and cross-sections of Tertiary rocks in the Thomas Range and northern Drum Mountains, Juab County, Utah: U.S. Geol. Survey Misc. Inv. Ser. Map I-1176

4. Rhyolitic ash-flow tuff with crystals of quartz, sanidine, plagioclase, and biotite

5. Lower member: gray-pink to red-brown; upper member: gray to black

6. Lower member: $180 \mathrm{~m}$; upper member: $20 \mathrm{~m}$

7. Lower member: moderately welded, forms cliffs; upper member: densely welded

8. Informal lower crystal tuff member and upper black glass tuff member

9. Unconformably overlies Mount Laird Tuff, Drum Mountains 
Rhyodacite, or Paleozoic rocks; underlies informal 0ligocene(?) megabreccia of northern Drum Mountains, or unconformably underlies Topaz Mountain Rhyolite or Quaternary sediments

10. Type locality: Exposures NW of Joy townsite, secs. 16, 17, and 22, T. 14 S., R. 11 W., Drum Mountains, Juab County, Utah.

\section{Juniper Gulch Member (Snaky Canyon Formation)}

1. Late Pennsylvanian (Missourian and Virgilian) and Early Permian (Wolfcampian)

2. Idaho (SE)

3. Skipp, Betty, and others, 1979, Upper Paleozoic carbonate bank in east-central Idaho--Snaky Canyon, Bluebird Mountain, and Arco Hills Formations, and their paleotectonic significance: U.S. Geol. Survey Bull. 1486, p. 29-32

4. Interbedded sandy and cherty limestone and dolomite

5. Weathers light gray

6. $597 \mathrm{~m}$

7. Thin- to thick-bedded, oolitic, $9 \mathrm{~m}$ thick, ledge-forming dolomite marker bed, fossiliferous

9. Gradationally overlies Gallagher Peak Sandstone Member (Snaky Canyon Formation); conformably underlies Phosphoria Formation

10. Type section: Exposures on Gallagher Peak, sec. 21, T. 9 N., R. 32 E., Copper Mountain quadrangle, Clark County, Idaho. Named for Juniper Gulch, about $1 \mathrm{~km} \mathrm{~S}$ of type section.

\section{Kakhonak Complex}

1. Permian(?), Triassic, and Jurassic

2. Alaska (C)

3. Detterman, R. L., and Reed, B. L., 1980, Stratigraphy, structure, and economic geology of the Iliamna quadrangle, Alaska: U.S. Geol. Survey Bull. 1368-B, p. B6-B9

4. Metamorphic rocks mainly of greenschist facies, including argillite, schist, and quartzite; locally of pyroxenehornfels, amphibolite, and granulite facies

6. $>1,000 \mathrm{~m}$

7. Roof pendants in Alaska-Aleutian Range batholith; complexly faulted and folded

9. Locally, apparently conformably, overlies Cottonwood Bay Greenstone; interbedded with and overlain by metavolcanic rocks; intruded by Jurassic rocks of Alaska-Aleutian Range batholith

10. Type locality: Exposures along Kakhonak Lake, SE of Illamna Lake, Iliamna quadrangle, Alaska Peninsula, Alaska. Named for Kakhonak Lake, River, and Bay.

\section{Kent Island Formation}

1. Pleistocene (Wisconsinan)

2. Maryland (EC), Delaware

3. Owens, J. P., and Denny, C. S., 1979, Upper Cenozoic deposits of the central Delmarva Peninsula, Maryland and Delaware: U.S. Geol. Survey Prof. Paper 1067-A, p. A24-A26

4. Sand, clay-silt, gravel

5. Light-colored

6. $12 \mathrm{~m} \max$ 
7. Crossbedded; tree stumps in growth position encased within clay-silt, estuarine deposit

9. Unconformably overlies Chesapeake Group, undivided, Pensauken Formation, Beaverdam Sand, and equivalents of Ironshire and Omar Formations

10. Type area: Exposures in bluffs on $\mathbf{N}$ side of Kent Island Formations, along Chester River, Queen Annes County, Md.

\section{Kimball Corners Conglomerate}

1. Late Proterozoic or Cambrian

2. New York (EC)

3. Fisher, D. W., 1980, Bedrock geology of the central Mohawk Valley, New York: New York State Mus. Map and Chart Ser. 33, Eastern Sheet

4. Meta-quartzite clasts in coarse quartz sand matrix, sandstone lens

5. Grayish-white, weathers yellow, orange, brown

6. $0-3 \mathrm{~m}$

7. Cobble- to boulder-size clasts, iron-stained

9. Overlies biotite gneiss; Irving Pond Formation exposed nearby; may be equivalent to Potsdam Sandstone

10. Type locality: Exposures along $N$ side of New York Highway 29, $0.55 \mathrm{~km} \mathrm{E}$ of Kimball Corners at intersection of New York Highways 29 and 147, Galway quadrangle, Saratoga County, N.Y.

King Tonopah Member (Fraction Tuff)

1. Miocene

2. Nevada (C)

3. Bonham, H. F., Jr., and Garside, L. J., 1979, Geology of the Tonopah, Lone Mountain, Klondike, and northern Mud Lake quads, Nevada: Nevada Bur. Mines and Geology Bull. 92, p. $51-54$

4. Vitric-lithic rhyolite ash-flow tuff with volcanic silt-

6. $200 \mathrm{~m}$

7. Moderately to densely welded

8. Two nearly identical cooling units

9. Unconformably overlies Mizpah Formation, Tonopah Summit Member (Fraction Tuff); unconformably underlies Heller Tuff

10. Type locality: Exposures extending from King Tonopah Mine, $1.6 \mathrm{~km} \mathrm{~N}$ of town of Tonopah, for $1.6 \mathrm{~km} \mathrm{NE}$ to top of nTV Tower Hill," secs. 24 and 25, T. 3 N., R. 42 E., Nye County, Nev.

\section{Kittitas Drift}

1. Pleistocene

2. Washington (C)

3. Porter, S. C., 1976, Pleistocene glaciation in the southern part of the North Cascade Range, Washington: Geol. Soc. America Bull., v. 87, no. 1, p. 66-69

4. Till, gravel

7. Moraines, dissected outwash fills; mantled by loess

8. Swauk Prairie Member, Indian John Member

9. Overlies Thorp Drift; underlies Lakedale Drift

10. Type locality: Designated for each member. Named for Kittitas Valley, upper Yakima River drainage basin, Kittitas County, Wash. 


\section{Klachopis Point Member (Makah Formation)}

1. Eocene, late

2. Washington (NW)

3. Snavely, P. D., Jr., and others, 1980, Makah Formation--a deep-marginal-basin sequence of late Eocene and Oligocene age in the northwestern Olympic Peninsula, Washington: U.S. Geol. Survey Prof. Paper 1162-B, p. 13

4. Micaceous sandstone with siltstone interbeds and calcareous concretions

6. $73 \mathrm{~m}$

7. Thick-bedded, amalgamated turbidite beds, ridge-forming

9. Lies $155 \mathrm{~m}$ above Dtokoah Point Member and $290 \mathrm{~m}$ below Third Beach Member; gradationally overlies unnamed siltstone of Makah Formation; upper contact covered

10. Type section: Wave-cut platform and headland exposures at Klachopis Point E of Neah Bay, NE1/4SE1/4 sec. 12, T. $33 \mathrm{~N}$., R. 15 W., Strait of Juan de Fuca, Clallam County, Wash.

\section{Kumuiliahi Formation}

1. Pleistocene

2. Hawaii (EC)

3. Macdonald, G. A., 1978, Geologic map of the crater section of Haleakala National Park, Maui, Hawaii: U.S. Geol. Survey Misc. Inv. Ser. Map I-1088, p. 5

4. Alkali olivine basalt

7. Thin-bedded pahoehoe and aa lava flows; many small white feldspar phenocrysts

9. Lower contact not exposed; unconformably underlies Kula Formation

10. Type locality: Exposures at base of $S$ wall of Haleakala Crater $\mathrm{N}$ and $\mathrm{NE}$ of Kumuiliahi, Haleakala National Park, SE Maui, Maui County, Hawaii.

\section{Kurry Creek Hember (Doyle Creek Formation)}

1. Late Triassic

2. Idaho (WC)

3. Vallier, T. L., 1977, The Permian and Triassic Seven Devils Group, western Idaho and northwestern Oregon: U.S. Geol. Survey Bull. 1437, p. 45-48

4. Conglomerate interlayered with sandstone, tuff, shale, argillite, and limestone

5. Dark-brown to greenish-black

6. $>270 \mathrm{~m}$

7. Mainly clastic rock sequence within upper part of Doyle Creek Formation; thick-bedded, crudely graded, shallow marine fan deposit

9. Conformably(?) overlies Wild Sheep Creek Formation; unconformably underlies Coon Hollow Formation or, locally, Martin Bridge Limestone. Unit was formerly Pittsburg Formation or W. R. Wagner (1945)

10. Type section: Spur SE of West Creek, from $465 \mathrm{~m}$ elevation to top of ridge, NE1/4SE1/4 sec. 29 to $\mathrm{SW} 1 / 4 \mathrm{sec} .28$, T. 27 N., R. 1 W., Idaho County, Idaho. Named for nearby Kurry Creek.

\section{Kuskulana Pass Formation}

1. Early Cretaceous (Hauterivian and Barremian)

2. Alaska (EC) 
3. Mackevett, E. M., Jr., and others, 1978, Geologic map of the McCarthy C-8 quadrangle, Alaska: U.S. Geol. Survey Geol. Quad. Map GQ-1418

4. Sandstone, siltstone, minor shale

5. Dark-greenish-gray or medium-gray; weathers brown

6. $300 \mathrm{~m}$

7. Thin-bedded, fine- and very fine grained, meagerly fossiliferous, shallow marine deposits

9. Gradationally overlies Berg Creek Formation; disconformably, or with slight angular unconformity, underlies Kennicott Formation

10. Type section: Exposures extending $S$ from NE1/4SE1/4SW1/4 sec. 32, T. 3 S., R. 10 E., to NE1/4SW1/4NW1/4 sec. 5 , T. 4 S., R. 10 E., upper drainage basin of Trail and Slatka Creeks, near Kuskulana Pass, McCarthy C-8 quadrangle, Wrangell Mountains, Alaska.

Lac La Croix Granite (Vermilion Granitic Complex)

1. Late Archean

2. Minnesota (NC)

3. Southwick, D. L., and Sims, P. K., 1980, The Vermilion Granitic Complex--a new name for old rocks in northern Minnesota: U.S. Geol. Survey Prof. Paper 1124-A, p. A5-A7

4. Biotite granite

5. Light-pink

7. Homogeneous texture, weakly altered

9. Grades into granite-rich migmatite and schist-rich migmatite

10. Type area: Outcrops S of Lac La Croix, St. Louis County, Minn. Reference locality: Roadcuts along Echo Trail $S$ of Little Indian Sioux River and $\mathrm{E}$ of Echo Lake, Shell Lake quadrangle.

Ladron Member (Kelly Limestone)

1. Early Mississippian (Osagean)

2. New Mexico (WC)

3. Armstrong, A. K., and Mamet, B. L., 1976, Biostratigraphy and regional relations of the Mississippian Leadville Limestone of the San Juan Mountains, southwestern Colorado:

U.S. Geol. Survey Prof. Paper 985, p. 17-19

4. Wackestone and packstone with nodular chert

5. Gray

6. $21.5 \mathrm{~m}$

7. Fossiliferous

9. Disconformably overlies Caloso Member (Kelly Limestone); unconformably underlies Sandia Formation

10. Type locality: Kelly Limestone type section on crest of Magdalena Mountains, NE1/4SW1/4 sec. 31, T. 2 S., R. 3 W., Socorro County, N. Mex. Named for Ladron Mountains, $N$ of Magdalena Mountains.

Lafayette Member (Epler Formation)

1. Early Ordovician

2. New Jersey (NC)

3. Markewicz, F. J., and Dalton, Richard, 1977, Stratigraphy and applied geology of the lower Paleozoic carbonates in northwestern New Jersey--Field Conference of Pennsylvania Geologists, 42d, Stroudsburg, 1977, Guidebook: [Harrisburg, Pennsylvania Geol. Survey] p. 21 
4. Dolomite with shale and chert beds

5. Black, gray, weathers orange gray

6. Range $15-76 \mathrm{~m}$

7. Fine- to medium-grained, laminated, with breccia zones

9. Overlies Big Springs Member (Epler Formation); underlies Beaver Run Member (Ontelaunee Formation)

10. Type section: Not stated, although unit is described in measured sections. Probably named for town of Lafayette, Sussex County, N.J.

Lake Angeline Till

1. Holocene

2. Wyoming (NC)

3. Nelson, R. S., 1977, Glacial deposits of the Lake Angeline quadrangle, Bighorn Mountains, Wyoming: Earth Sci. Bull., v. 10 , no. 1 , p. 18

4. Cobble and boulder till in sand matrix

5. Pinkish-gray, weathers light gray

6. Range 3-4 m

7. Angular boulders, very little matrix; loop moraines at mouths of cirques

9. Overlies Chill Lakes Till

10. Type locality: Moraine surrounding Lake Angeline, SE1/4 sec. 16, T. 50 N., R. 85 W., Bighorn Mountains, Johnson County, Wyo.

Lakedale Drift

1. Pleistocene

2. Washington (C)

3. Porter, S. C., 1976, Pleistocene glaciation in the southern part of the North Cascade Range, Washington: Geol. Soc. America Bull., v. 87, no. 1, p. 70-72

4. Till, gravel

7. Moraines, outwash terraces; mantled by loess

8. Bullfrog, Ronald, Domerie, and Hyak Members

9. Overlies Kittitas Drift; underlies Holocene alluvium

10. Type locality: Designated for each member. Named for community of Lakedale, upper Yakima River drainage basin, Kittitas County, Wash.

Lake Durant Formation

1. Proterozoic

2. New York (NE)

3. McLelland, James, and Isachsen, Ingvar, 1980, Structural synthesis of the southern and central Adirondacks--a model for the Adirondacks as a whole and plate tectonics interpretations: Geol. Soc. America Bull. (pt. 2, microfiche), v. 91 , no. 2, p. 223-224, 233-234

4. Granitic gneiss, interlayered with calc-silicate rocks near base

5. Tan, pink, light-green

6. Range $200-1,000 \mathrm{~m}$

7. Characterized by lithologic consistency and areal continuity

9. Overlies Cedar River Formation, underlies Blue Mountain Lake Formation

10. Type locality: N of Lake Durant, $2.7 \mathrm{~km} \mathrm{~S}$ of Blue Mountain Lake on New York Route 28-30, Blue Mountain quadrangle, Hamilton County, N.Y. 
Lake Merritt Member (Paluxy Sand?)

1. Early Cretaceous

2. Texas (C)

3. Owen, M. T., 1979, The Paluxy Sand in north-central Texas: Baylor Geol. Studies Bull. 36, p. 8, 15-21

4. Sand, silt, clay

6. $6 \mathrm{~m}$, range $3-6 \mathrm{~m}$

7. Horizontally bedded, tidal flat deposit

9. Conformably overlies Glen Rose Limestone (Trinity Group); disconformably underlies Georges Creek Member (Paluxy Sand)

10. Type locality: State Highway $16,8.2 \mathrm{~km}$ NE of Goldthwaite, Mills County, Tex. Named for exposure near Lake Merritt, Mills County.

Lamerdorf Tuff Member (Escalante Desert Formation)

1. Oligocene

2. Utah.(SW)

3. Campbell, D. R., 1978, Stratigraphy of pre-Needles Range Formation ash-flow tuffs in the northern Needle Range and southern Wah Wah Mountains, Beaver County, Utah: Brigham Young Univ. Geol. Studies, v. 25 , no. 3, p. 33-38

4. Ash-flow tuff

5. Pink, brown, lavender

6. $109 \mathrm{~m}$, range 21-109 $\mathrm{m}$

7. Moderately to densely welded, vitric

8. Informal lower vitric-crystal tuff and upper vitric-lithic tuff

9. Overlies tuff of Sulphur Spring; underlies Beers Spring Member (Escalante Desert Formation)

10. Type locality: E of Willow Creek Spring and $W$ and $S$ of Bucket Ranch Spring, SE1/4 sec. 2, T. 29 S., R. 16 W., to S1/2 sec. 4, T. 29 S., R. 15 W., Wah Wah Mountains, Lamerdorf Peak quadrangle, Beaver County, Utah.

Latigo Canyon Breccia Meaber (Calabasas Formation)

1. Miocene, middle

2. California (SC)

3. Yerkes, R. F., and Campbell, R. H., 1979, Stratigraphic nomenclature of the central Santa Monica Mountains, Los Angeles County, California: U.S. Geol. Survey Bull. 1457-E, p. E23

4. Sedimentary breccia

6. $91 \mathrm{~m}$

7. Clasts of red-bed (Sespe) sandstone and fossiliferous (Vaqueros) sandstone

9. Overlies Escondido Canyon Shale Member (Calabasas Formation); intertongues with unnamed epiclastic volcanic breccia; underlies Solstice Canyon Tongue (Conejo Volcanics)

10. Type area: Latigo Canyon, Santa Monica Mountains, EC Point Dume quadrangle, Los Angeles County, Calif.

Latite Ridge Latite (Tintic Mountain Volcanic Group)

1. Oligocene, middle

2. Utah (C)

3. Morris, H. T., and Lovering, T. S., 1979, General geology and mines of the East Tintic mining district, Utah and Juab Counties, Utah: U.S. Geol. Survey Prof. Paper 1024, p. 3840 
4. Latite airfall and water-laid tuff and welded tuff

5. Lower member: white; upper member: reddish-brown

6. Lower member: range $<1-30 \mathrm{~m}$; upper member: range $38-152 \mathrm{~m}$

8. Informal lower airfall tuff member and upper welded tuff member

9. Unconformably overlies Packard Quartz Latite or Copperopolis Latite (Tintic Mountain Volcanic Group); unconformably underlies Big Canyon Latite (Tintic Mountain Volcanic Group), or North Standard and Pinyon Queen Latites (Laguna Springs Volcanic Group), or disconformably underlies Pinyon Creek Conglomerate

10. Type locality: Exposures on Latite Ridge, NW1/4 sec. 23, and NE1/4 sec. 27, T. 10 S., R. 2 W., East Tintic Mountains, $16 \mathrm{~km} \mathrm{SW}$ of East Tintic mining district, Juab County, Utah.

Laucomer Member (Snake Creek Formation)

1. Miocene, middle

2. Nebraska (NW)

3. Skinner, M. F., Skinner, S. M., and Gooris, R. J., 1977, Stratigraphy and biostratigraphy of late Cenozoic deposits in central Sioux County, western Nebraska: Am. Mus. Nat. History Bull., v. 158, art. 5, p. 310-311

4. Quartz sand, gravel, fossil fragments, ash

6. $14.3 \mathrm{~m}$, range $1.2-14.3 \mathrm{~m}$

7. Unconsolidated, fluviatile, fossiliferous (vertebrates)

9. Unconformably overlies Murphy Member; underlies soil at surface

10. Type section: NE side of olcott Hill, NE1/4SW1/4SE1/4 sec. 3, T. 25 N., R. 55 W., near Laucomer Ranch, Sioux County, Nebr.

\section{Lawson Creek Formation}

1. Middle Proterozoic

2. Idaho (C)

3. Hobbs, S. W., 1980, The Lawson Creek Formation of Middle Proterozoic age in east-central Idaho: U.S. Geol. Survey Bull. 1482-E, p. 3-9

4. Quartzite, siltstone, argillite

5. Medium-reddish-purple, dark-purplish-gray, and maroon

6. $>1,300 \mathrm{~m}$; total thickness unknown

7. Predominantly thin-bedded, mud chip breccia, ripple marks, micaceous partings

8. Informal basal quartzite transition zone, middle quartzite and silty argillite unit, upper argillite unit

9. Conformably and gradationally overlies Swauger Formation; unconformably underlies Challis Volcanics

10. Type locality: Exposures in Lost River Range where Lawson Creek flows into Pahsimeroi Valley, mostly in secs. 4 and 9, T. 14 N., R. 21 E., May quadrangle, Custer County, Idaho.

\section{Leesburg Limestone Conglonerate Member (Bull Run Formation)}

\section{Late Triassic}

2. Virginia (NE), Maryland

3. Lee, K. Y., 1977, Triassic stratigraphy in the northern part of the Culpeper basin, Virginia and Maryland: U.S. Geol. Survey Bull. 1422-C, p. C6

4. Limestone conglomerate, metamorphosed into marble where in contact with diabase 
5. Gray

7. $76 \mathrm{~m}$, range $76-1,070 \mathrm{~m}$

9. Overlies and intertongues with Balls Bluff Siltstone (Newark Group); underlies and intertongues with unnamed basalticflow-bearing clastics member of Bull Run Formation (Newark Group)

10. Type section: SE roadcuts at junction of U.S. Route 15 bypass and entrance road to Balls Bluff National Cemetery, $\mathrm{SE}$ Waterford quadrangle, Loudoun County, Va. Named for town of Leesburg.

Lehigh Acres Member (Tamiami Formation)

1. Miocene, late

2. Florida (SE)

3. Peck, D. M., and others, 1979, Stratigraphy and paleoecology of the Tamiami Formation in Lee and Hendry Counties, Florida: Gulf Coast Assoc. Geol. Socs. Trans., v. 29, p. 331-333

4. Limestone and calcareous sand, with minor clay and marl

6. $18.5 \mathrm{~m}$

7. Highly porous and permeable shallow-water aquifer

10. Type section: U.S.G.S. water test well L-1984, depthinterval $63.7-82.2 \mathrm{~m}$, SW1/4NE $1 / 4 \mathrm{SE} 1 / 4 \mathrm{sec} .22, \mathrm{~T} .46 \mathrm{~S}$., R. $26 \mathrm{E}$., approx $1 \mathrm{~km} \mathrm{E}$ of intersection of Alico Road and Corkscrew Road, Lee County, Fla. Named for nearby community of Lehigh Acres.

\section{Lenihan Canyon Tuff}

1. Oligocene

2. Nevada (WC)

3. Bingler, E. C., 1978, Abandonment of the name Hartford Hill Rhyolite Tuff and adoption of new formation names for middle Tertiary ash-flow tuffs in the Carson City-Silver City area, Nevada: U.S. Geol. Survey Bull. 1457-D, p. D9-11

4. Hornblende-biotite quartz latite tuff

5. Pale-lavender-brown

6. $300 \mathrm{~m}$

7. Moderately to strongly welded, mostly devitrified, finegrained, crystal-vitric; simple cooling unit

9. Disconformably overlies Mickey Pass Tuff; unconformably underlies younger Tertiary rocks; older than Nine Hill Tuff

10. Type section: Exposures $0.8 \mathrm{~km} \mathrm{NE}$ of Lenihan Canyon, NE1/4NE1/4 sec. $14 \mathrm{~T}$. $16 \mathrm{~N}$, , R. 20 E., Virginia City quadrangle, Storey County, Nev.

Leopold Limestone Member (Branchville Formation)

1. Late Mississippian (Chesterian)

2. Indiana (SC)

3. Gray, H. H., 1978, Buffalo Wallow Group--upper Chesterian (Mississippian) of southern Indiana: Indiana Geol. Survey Occasional Paper 25, p. 10

4. Limestone with interbedded shale

5. White to gray, weathers yellow brown

6. $3.5 \mathrm{~m}$

9. Conformably overlies shale of Branchville Formation; conformably underlies Tobinsport Formation

10. Type section: Leopold Section, NW1/4 sec. 11 and SW1/4 
sec. 2, T. 5 S., R. 2 W., $W$ of Leopold along Indiana Route 37, Perry County, Ind.

\section{Lilesville Granite}

1. Late Mississippian and Early Pennsylvanian

2. North Carolina (C)

3. Waskom, J. D., and Butler, J. R., 1971, Geology and gravity of the Lilesville Granite batholith, North Carolina: Geol. Soc. America Bull., v. 82, no. 10, p. 2827-2844

4. Adamellite, granodiorite, and tonalite

7. Medium- to coarse-grained matrix, porphyritic rapakivi texture

9. Intrudes metamorphosed volcanic rocks and argillites

10. Type locality: Lilesville, Anson County, N.C.

\section{Limberlost Dolomite}

1. Middle Silurian

2. Indiana (NE)

3. Droste, J. B., and Shaver, R. H., 1976, The Limberlost Dolomite of Indiana--a key to the great Silurian facies in the southern Great Lakes area: Indiana Geol. Survey Occasional Paper 15, $21 \mathrm{p}$.

4. Dolomite

5. Brown, tan

6. $5.5 \mathrm{~m}$, range $<1-21 \mathrm{~m}$

7. Fine- to medium-grained, oolitic, reef-bearing

9. Conformably overlies Salamonie Dolomite; conformably underlies Waldron Formation

10. Type section: John $W$. Karch Stone Co. quarry, SW1/4SW1/4 sec. 31, T. 25 N., R. 15 E., near New Corydon, Adams County, Ind. Named for Limberlost area near Geneva.

\section{Lindsey Quartzite (Deep Lake Group)}

1. Early Proterozoic

2. Wyoming (SE)

3. Karlstrom, K. E., and Houston, R. S., 1979, Stratigraphy and uranium potential of Early Proterozoic metasedimentary rocks in the Medicine Bow Mountains, Wyoming: Wyoming Geol.

Survey Rept. Inv. 13, p. 13-15, 42-43

4. Quartzite with lenses of quartz pebbles

5. White to light-gray

6. $410 \mathrm{~m}$

7. Trough cross-beds, ripple marks; fluvial deposits

9. Conformably overlies Magnolia Formation; underlies Campbell Lake Formation with sharp to gradational contact (near type section), or overlies Cascade Quartzite

10. Type section: NW1/4 sec. 2 and NE1/4 sec. 3, T. $16 \mathrm{~N}$. , R. 80 W., Medicine Bow Mountains, Carbon County, Wyo. Named for exposures $\mathrm{W}$ of Lindsey Lake, sec. 26, T. 17 N., R. 79 W.

\section{Link Spring Tuff Member (South Park Formation)}

1. Paleocene

2. Colorado (C)

3. Wyant, D. G., and Barker, Fred, 1976, Geologic map of the Milligan Lakes quadrangle, Park County, Colorado: U.S. Geol. Survey Geol. Quad. Map GQ-1343

4. Tuff, with volcanic breccia, andesite flows, and minor porphyry-cobble conglomerate 
5. Gray, brown, and pale-green

6. Range $<1-213 \mathrm{~m}$

7. Contains leaf impressions; forms ridges; tongue of thicker unnamed tuffaceous mudstone member $S$ of Elkhorn quadrangle

9. Overlies unnamed conglomeratic member; underlies unnamed arkosic member

10. Type locality: Exposures $N$ of Link Spring on Elkhorn Road, sec. 6, T. 10 S., R. 75 W., Elkhorn quadrangle, Park County, Colo.

\section{Linton Member (Fox Hills Formation)}

1. Late Cretaceous

2. North Dakota (SC), South Dakota

3. Klett, M. C., and Erickson, Mark, 1976, Type and reference sections for a new member of the Fox Hills Formation, Upper Cretaceous (Maestr.) in the Missouri Valley region, North and South Dakota: North Dakota Acad. Sci. Proc., v. 28, pt. 2, p. 3-24

4. Siliceous arenite to subgraywacke sandstone with volcanic shards

5. Olive-gray to grayish-brown

6. $2.4 \mathrm{~m}$, range $0.2-7 \mathrm{~m}$

7. Fine-grained, fossiliferous, estuarine channel deposit, forms butte caps

9. Overlies unnamed facies of Fox Hills Formation; underlies Hell Creek Formation

10. Type section: Section A216, composite section from NW tip to center of $\mathrm{N}$ side of butte, $\mathrm{N} 1 / 2$ secs. 8 and $9, \mathrm{~T} .132 \mathrm{~N}$., R. 76 W., $1.6 \mathrm{~km} \mathrm{E}$ of Linton, Emmons County, N. Dak.

\section{Little Copper Formation (Copper Basin Group)}

1. Early Mississippian (Kinderhookian)

2. Idaho ( $\mathrm{SC})$

3. Paull, R. A., and Gruber, D. P., 1977, Little Copper Formation--new name for lowest formation of Mississippian Copper Basin Group, Pioneer Mountains, south-central Idaho: Am.

Assoc. Petroleum Geologists Bull., v. 61, no. 2, p. 256
4. Argillite with interbedded quartzite, conglomerate, and limestone

5. Dark-gray

6. $1,120 \mathrm{~m}$

7. Thin- to medium-bedded, blocky weathering

9. Base of formation not exposed and stratigraphic relation to underlying Milligen Formation not known; grades eastward into lower part of McGowan Creek Formation (Copper Basin Group); gradationally underlies Drummond Mine Limestone (Copper Basin Group)

10. Type section: Basal part of Copper Basin Group type section, $150 \mathrm{~m}$ up $\mathrm{N}$ flank of ridge above Little Copper Creek, SW1/4NE1/4SE1/4 sec. 22, and continues $N 45^{\circ} \mathrm{E}$ to center of NE1/4NW1/4 sec. 23, T. 4 N., R. 21 E., Pioneer Mountains, Blaine County, Idaho. Little Copper Creek is tributary of Copper Creek, which joins Muldoon Creek at Muldoon.

\section{Little Falls Formation (Mille Lacs Group)}

1. Precambrian, middle

2. Minnesota (C) 
3. Morey, G. B., 1978, Lower and middle Precambrian stratigraphic nomenclature for east-centrál Minnesota: Minnesota Geol. Survey Rept. Inv. 21, p. 18-20

4. Argillaceous slate, phyllite, and schist intercalated with quartz-rich metasiltstone and metagraywacke

5. Gray

7. Thin- to thick-bedded, abundant carbonate concretions

9. Infolded with early Precambrian gneissic rocks; to $\mathrm{N}$, passes into Mille Lacs Group, undivided, or may overlie Randall Formation (Mille Lacs Group)

10. Type locality: Exposures on and near Mill Island in valley of Mississippi River near center of city of Little Falls, sec. 8, T. 41 N., R. 32 W., and sec. 19, T. 129 N., R. 32 W., Morrison County, Minn.

Little Northeast Creek Member (James Run Formation)

1. Paleozoic, early

2. Maryland (NE)

3. Higgins, M. W., 1977, Six new members of the James Run Formation, Cecil County, northeastern Maryland: U.S. Geol. Survey Bull. 1435-A, p. A123

4. Dacitic to rhyolitic granofels with relict phenocrysts of plagioclase and quartz

5. Grayish-white to gray

6. $1,370 \mathrm{~m}$

7. Fine- to medium-grained, massive; at least four phases of folding; of metavolcanic to metasubvolcanic origin

9. Grades into Frenchtown Member and biotite gneiss of sedimentary origin; probably partly equivalent to Principio. Furnace Member; underlies Gilpins Falls Member

10. Type section: Section along Little Northeast Creek between outcrop belts of Gilpins Falls Member, on flanks of major anticline that trends NE from near Theodore, Cecil County, Md.

\section{Livengood Dome Chert}

1. Late Ordovician

2. Alaska (NE)

3. Chapman, R. M., and others, 1980, The Livengood Dome Chert, a new Ordovician formation in central Alaska, and its relevance to displacement on the Tintina fault: U.S. Geol. Survey Prof. Paper 1126-F, p. F1-F13

4. Chert with interbedded shale, argillite, and siltstone

5. Light-gray to grayish-black; weathers gray, green, yellow, reddish brown, red

6. Range 300-600 m

7. Thick- to thin-bedded, jointed, brecciated; complex structure with overturned folds and faults; shale fossiliferous (graptolites)

9. Unconformably overlies Precambrian(?) or Cambrian rocks; underlies Middle Silurian to Early Devonian unnamed dolomite and limestone unit; Livengood Dome Chert and unnamed unit formerly were unnamed lower and upper units of Livengood Chert of Mertie (1937) (name abandoned)

10. Type area: Exposures between valleys of Lost Creek and South Fork of Hess Creek, Livengood C-4 quadrangle, Alaska. Reference section in borrow pit $13.6 \mathrm{~km} \mathrm{~W}$ of town 
of Livengood and $2.4 \mathrm{~km} \mathrm{~W}$ of Lost Creek, SW1/4 sec. 8, T. 8 N., R. 6 W.

Loch Raven Schist (Wissahickon Group)

1. Cambrian-Ordovician(?)

2. Maryland (NC)

3. Crowley, W. P., 1976, The geology of the crystalline rocks near Baltimore and its bearing on the evolution of the eastern Maryland Piedmont: Maryland Geol. Survey Rept. Inv. 27, p. 9-11, 23-24

4. Biotite-plagioclase-muscovite-quartz schist with pods of vein quartz

6. Range $<1->600 \mathrm{~m}$

7. Medium- to coarse-grained

8. Hydes Marble Member, Rush Brook Member

9. Overlies Cockeysville Marble; underlies Oella Formation (Wissahickon Group) or Piney Run Formation (Wissahickon Group)

10. Type locality: Outcrops on banks of Loch Raven Reservoir from Papermill Road (Ashland Avenue) $S$ for $1.5 \mathrm{~km}$, Baltimore County, Md.

Lock Haven Formation

1. Late Devonian

2. Pennsylvania (C)

3. Faill, R. T., and Wells, R. B., 1977, Bedrock geology and mineral resources of the Salladasburg and Cogan Station quadrangles, Lycoming County, Pennsylvania: Pennsylvania Geol. Survey, 4 th ser., Atlas 133cd, p. 32-44

4. Interbedded shale, siltstone, sandstone, minor conglomerate

5. Gray

6. $1,189 \mathrm{~m}$

7. Sandstone lenticular, cross-bedded; fossiliferous marine deposits

9. Gradationally and conformably overlies Brallier Formation; conformably underlies Irish Valley Member (Catskill Formation)

10. Type section: Exposure along Queens Run Road from borrow pit $1.5 \mathrm{~km} \mathrm{NW}$ of Susquehanna River (West Branch) bridge at Lock Haven, $1.5 \mathrm{~km} \mathrm{NW}$ to lower slopes of Simcox Mountain, N of junction of Queens Run Road and Swissdale Road, Lock Haven quadrangle, Clinton County, Pa.

\section{Lodoga Formation}

1. Early Cretaceous

2. Cali fornia (NW)

3. Ingersoll, R. V. Rich, E. I., and Dickinson, W. R., 1977, Field guide--Great Valley Sequence, Sacramento Valley: Geol. Soc. America, Cordilleran Sec., Ann. Mtg., [Guidebook $8]$, p. $28,31-32$

4. Siltstone, with many lenticular beds of sandstone and a few conglomerate lenses

5. Dark-gray

6. $4,200 \mathrm{~m}$, range $3,600-4,800 \mathrm{~m}$

7. Thin- to thick-bedded; mixed plutonic and volcanic detritus deposited in deep-marine trough

8. Leesville Sandstone Member at base; informal Eckman Canyon sandstone member 
9. Conformably overlies Stony Creek Formation; conformably underlies Boxer Formation

10. Type section: Along road between Lodoga and Sites, Lodoga quadrangle, Colusa County, Calif.

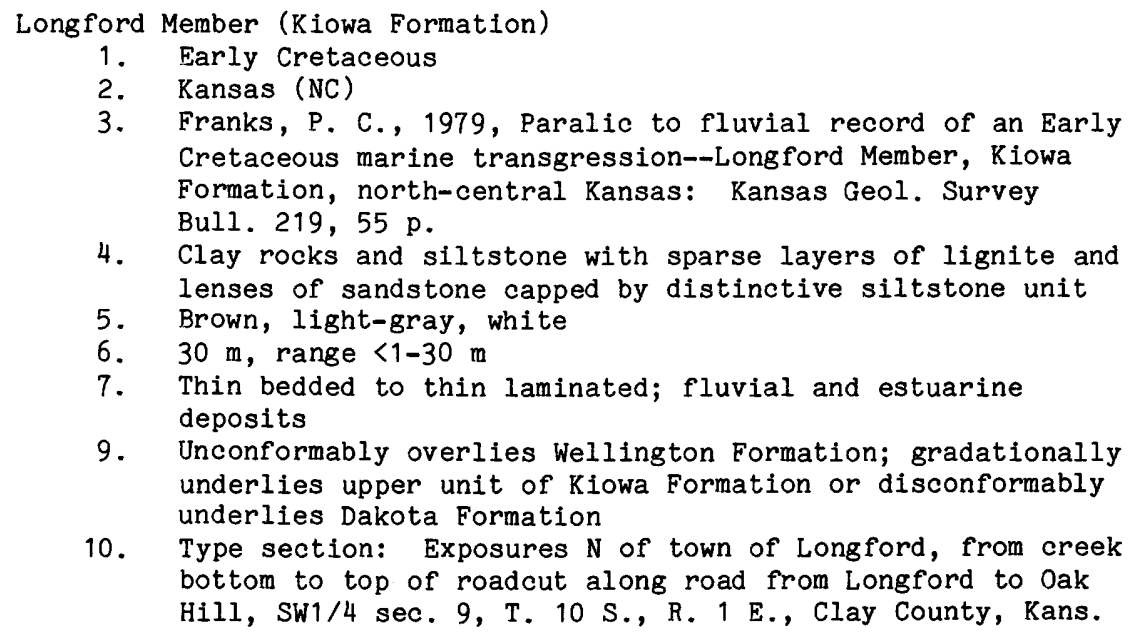

4. Clay rocks and siltstone with sparse layers of lignite and lenses of sandstone capped by distinctive siltstone unit

5. Brown, light-gray, white

6. $30 \mathrm{~m}$, range $<1-30 \mathrm{~m}$

7. Thin bedded to thin laminated; fluvial and estuarine deposits

9. Unconformably overlies Wellington Formation; gradationally underlies upper unit of Kiowa Formation or disconformably underlies Dakota Formation

10. Type section: Exposures $N$ of town of Longford, from creek bottom to top of roadcut along road from Longford to Oak Hill, SW1/4 sec. 9, T. 10 S., R. 1 E., Clay County, Kans.

\section{Long Island Creek Gneiss}

1. Precambrian, late(?) and (or) Paleozoic, early(?)

2. Georgia (NW)

3. Higgins, M. W., and McConnell, K. I., 1978, The Sandy Springs Group and related rocks in the Georgia Piedmont-nomenclature and stratigraphy: U.S. Geol. Survey Bull. 1457-A, p. A104 (Also published in: Georgia Geol. Survey Bull. 93, p. 53-54, 1978)

4. Epidote-biotite-plagioclase gneiss

5. Dark-gray, weathers yellow

7. Weathers to massive saprolite

9. In fault contact along SE boundary of Sandy Springs Group; in fault contact with all other adjacent rocks

10. Type area: Exposures on SE side of Long Island Creek near and along Roswell Road, Sandy Springs quadrangle, Fulton County, Ga.

\section{Long Lake Till}

1. Holocene

2. Wyoming (NC)

3. Nelson, R. S., 1977, Glacial deposits of the Lake Angeline quadrangle, Bighorn Mountains, Wyoming: Earth Sci. Bull. v. 10 , no. 1 , p. 16

4. Cobble and boulder till in quartz and feldspar matrix

5. Reddish-brown, weathers light yellowish brown

6. Range $15-38 \mathrm{~m}$

7. Loose; end and ground moraines

9. Overlies Sherd Lake Till; underlies informal Lake Lame Deer till

10. Type locality: Moraine enclosing Long Lake, center sec. 25, T. 15 N., R. 85 W., Bighorn Mountains, Johnson County, Wyo. 
Long Pond Gneiss Menber (Nashoba Formation)

1. pre-Silurian

2. Massachusetts (C)

3. Bell, K. G., and Alvord, D. C., 1976, Pre-Silurian stratigraphy of northeastern Massachusetts: Geol. Soc. America Mem. 148, p. 184-185, 208, app. 1 (In pocket)

4. Sillimanitic biotite gneiss with lenticular bodies of amphibolite

5. Medium-gray

6. $1,160 \mathrm{~m}$

7. Medium-grained, stratified, relict sedimentary structures

9. Overlies Fort Pond Member; underlies Beaver Brook Member

10. Type locality: Belt $1,530^{\circ} \mathrm{m}$ wide extending from SW shore of Long Pond in town of Littleton, SW to $S$ and $W$ boundaries of Westford quadrangle, Middlesex County, Mass.

Lookout Mountain Conglomerate Member (Wasatch Formation)

1. Eocene, early

2. Wyoming (WC)

3. Dorr, J. A., Jr., Spearing, D. R., and Steidtmann, J. R., 1977, Deformation and deposition between a foreland uplift and an impinging thrust belt--Hoback Basin, Wyoming: Geol. Soc. America Spec. Paper 177, p. 23-24

4. Conglomerate with sandstone and limestone clasts, sandstone interbeds

5. Red, gray

6. $>660 \mathrm{~m}$

7. Large, angular to poorly rounded clasts in sandstone matrix; alluvial fan deposits

9. Unconformably overlies Gannett Formation or other Mesozoic rocks; relation to Chappo Member (Wasatch Formation) and Pass Peak Formation to $\mathrm{N}$ and $\mathrm{E}$ not clear; lies at surface

10. Type area: Exposures along South Fork Hoback River and on Lookout Mountain, T. 35 N., Rs. 114 and 115 W., Sublette County, Wyo.

\section{Lookout Hountain Ranch Drift}

1. Pleistocene

2. Washington (C)

3. Waitt, R. B., Jr., 1979, Late Cenozoic deposits, landforms, stratigraphy, and tectonism in Kittitas Valley, Washington: U.S. Geol. Survey Prof. Paper 1127, p. 12-13

4. Till

5. Dark-gray to black; produces reddish-brown soil

6. $>50 \mathrm{~m}$

7. Lateral moraines; conspicuously weathered

9. Unconformably overlies Grand Ronde Basalt; younger than Thorp Gravel, older than Kittitas Drift. Unit includes S. C. Porter's (1976) informal till facies of Thorp Drift; Porter's Thorp Drift is here restricted to its outwash facies and renamed Thorp Gravel

10. Type locality: Exposure at top of NW scarp of Lookout Mountain, SE1/4SW1/4 sec. 36, T. $20 \mathrm{~N} .$, R. $16 \mathrm{E}$, Cle Elum quadrangle, Kittitas County, Wash. Named for ranch that occupies top of Lookout Mountain. 
2. Utah (NW), Nevada

3. Budge, D. R., and Sheehan, P. M., 1980, The Upper Ordovician through Middle Silurian of the eastern Great Basin--Pt. 1, Introduction--historical perspective and stratigraphic synthesis; Pt. 2, Lithologic descriptions: Milwaukee Public Mus. Contr. Biology and Geology, no. 28, p. 15 (pt. 1); no. 29, p. 25-26 (pt. 2)

4. Dolomite

5. Light-gray and dark-gray interbedded

6. $67 \mathrm{~m}$

7. Thin- to thick-bedded, microcrystalline to finely crystalline laminated

9. Overlies Barn Hills Member; underlies Floride Member

10. Type section: Exposures $\mathrm{N}$ of Lost Canyon, NE1/4 sec. 30 , T. 3 N., R. 17 W., Silver Island Mountains, Tooele County, Utah.

Love Formation

1. Pleistocene

2. Texas (WC)

3. Akersten, W. A., 1970, Red Light local fauna (Blancan) of the Love Formation, southeastern Hudspeth County, Texas: Texas Memorial Mus. Bul1. 20, p. 4-8

4. Silty clay and gravel interfingering with silt, sand, and clay

5. Reddish-brown, orange-pink

6. $36 \mathrm{~m}$

7. Lenticular, cross-bedded, basin and fluvial deposits; vertebrate fossils

9. Conformably overlies Bramblett Formation; top eroded, capped by pediment gravel; in fault contact with Lower Cretaceous sedimentary rocks

10. Type section: Section RL-1, along stream in TMM locality 40664, on John D. Bramblett Ranch, Hudspeth County, Tex. Named for Love triangulation station, lat $30^{\circ} 48^{\prime} 27^{\prime \prime}$, long $105^{\circ} 12^{\prime} 12^{\prime \prime}$.

Loves Park Member (Dunleith Formation)

1. Middle Ordovician

2. Illinois (NC)

3. Willman, H. B., and Kolata, D. R., 1978, The Platteville and Galena Groups in northern Illinois: Illinois Geol. Survey Circ. 502, p. 50-51

4. Dolomite, cherty dolomite, bentonite

6. $15 \mathrm{~m}$

8. Calmar, Conover, Nasset, and Haldane Bentonite Beds

9. Overlies Fairplay Member; underlies Wyota Member; equivalent of Mortimer, Rivoli, Sherwood, and Wall Members (Dunleith Formation) in area $E$ and $S$ of Freeport, Ill., where those members cannot be divided

10. Type section: Harlem Southeast section, quarry $1.6 \mathrm{~km} \mathrm{SE}$ of Harlem, center SE1/4 sec. 33, T. 45 N., R. 2 E., Winnebago County, Ill. Named for town of Loves Park, $1.6 \mathrm{~km} \mathrm{SW}$ of type section.

Lower Monumental Member (Saddle Mountains Basalt)

1. Miocene, late

2. Washington (SE) 
3. Swanson, D. A., and others, 1979, Revisions in stratigraphic nomenclature of the Columbia River Basalt Group: U.S. Geol. Survey Bull. 1457-G, p. G53-G54

4. Basalt

6. $30 \mathrm{~m}$, range $25-60 \mathrm{~m}$

7. Nearly aphyric, one flow

9. Overlies river gravel in an ancestral Snake River canyon whose lower end appears to be eroded into Ice Harbor Member; believed to be youngest basalt of Columbia River Basalt Group and its Yakima Basalt Subgroup

10. Type locality: Prominent roadcut $1 \mathrm{~km} \mathrm{~S}$ of Lower Monumental Dam, NW1/4SE1/4 sec. 3, T. $12 \mathrm{~N}$., R. $34 \mathrm{E}$., Lower Monumental Dam quadrangle, Walla Walla County, Wash.

Lyman Member (Ammonoosuc Formation)

1. Middle Ordovician

2. New Hampshire (WC)

3. Prager, G. D., 1980, Stratigraphy of the Gardner Mountain area, New Hampshire: Northeastern Geology, v. 2, no. 1, p. 34

4. Mafic chlorite schist

5. Dark-green

7. Slaty, well-developed cleavage

9. Overlies West Bath Member (Ammonoosuc Formation); underlies Partridge Formation

10. Type locality: In road along E side of Gardner Mountain, $2.2 \mathrm{~km}$ WNW of Lyman village, Grayton County, N.H.

Lynnhaven Member (Tabb Formation)

1. Pleistocene, late

2. Virginia (SE)

3. Johnson, G. H., 1976, Geology of the Mulberry Island, Newport News North, and Hampton quadrangles, Virginia: Virginia Div. Mineral Resources Rept. Inv. 41, p. 35-37

4. Gravelly and clayey sand

5. Bluish-gray, reddish-brown

6. $\quad 1.77 \mathrm{~m}$, range $<1-2 \mathrm{~m}$

7. Beach and nearshore marine deposits

9. Unconformably overlies Sedgefield Member (Tabb Formation), Norfolk Formation, or Yorktown Formation; unconformably underlies Poquoson Member (Tabb Formation)

10. Type section: Exposure along Butler Farm ditch, $1.08 \mathrm{~km} \mathrm{~W}$ of intersection of Magruder Boulevard (State Highway A134) and Butler Farm Road, city of Hampton, Va. Named for subdivision of Lynnhaven, city of Hampton.

Mableton Amphibolite Member (Powers Ferry Formation)

1. Precambrian, late(?) and (or) Paleozoic, early(?)

2. Georgia (NW)

3. Higgins, M. W., and McConnell, K. I., 1978, The Sandy Springs Group and related rocks in the Georgia Piedmont-nomenclature and stratigraphy: U.S. Geol. Survey Bull. 1457-A, p. A102-A103 (Also published in: Georgia Geol. Survey Bull. 93, p. 52, 1978)

4. Hornblende-plagioclase amphibolite

6. Range 500-700 m

7. Layered

9. Within Powers Ferry Formation 
10. Type area: Exposures along and $\mathrm{N}$ of Fountain Road NE of Mableton, Mableton quadrangle, Cobb County, Ga.

Madawaska Lake Formation

1. Ordovician and Early Silurian(?) (Caradocian to Llandoverian(?))

2. Maine (NE), Canada (New Brunswick)

3. Roy, D. C., and Mencher, Ely, 1976, Ordovician and Silurian stratigraphy of northeastern Aroostook County, Maine: Geol. Soc. America Mem. 148, p. 29-31, 47-48

4. Slate interbedded with siltstone and graywacke

5. Green-gray, gray, weathers orange

6. $>600 \mathrm{~m}$

7. Fine-grained, brittle, thin-bedded

9. Oldest rocks exposed in cores of anticlines; interfingers with Winterville Formation; underlies Aroostook River Formation or unconformably underlies Frenchville Formation

10. Type area: Exposures along $\mathrm{N}$ shore of Madawaska Lake, along Maine Route $161,3.7 \mathrm{~km} \mathrm{~N}$ of Little Madawaska River, Aroostook County, Maine.

\section{Magnolia Formation (Deep Lake Group)}

1. Early Proterozoic

2. Wyoming (SE)

3. Karlstrom, K. E., and Houston, R. S., 1979, Stratigraphy and uranium potential of Early Proterozoic metasedimentary rocks in the Medicine Bow Mountains, Wyoming: Wyoming Geol.

Survey Rept. Inv. 13, p. 11-13, 40-42

4. Arkosic conglomerate, quartzite

6. Conglomerate: $150 \mathrm{~m}$; quartzite: $425 \mathrm{~m}$

7. Conglomerate, poorly sorted, radioactive; quartzite, coarsegrained; fluvial deposits

8. Informal lower radioactive conglomerate member and upper quartzite member

9. Unconformably overlies Phantom Lake Suite; conformably underlies Lindsey Quartzite (Deep Lake Group)

10. Type section: Radioactive conglomerate: center sec. 10, T. 16 N., R. 80 W.; quartzite: E of Stamp Mill Lake, sec. 16, T. 16 N., R. 80 W., Medicine Bow Mountains, Carbon County, Wyo. Derivation of name not stated.

Maiden Creek Member (Allentown Formation)

1. Late Cambrian

2. Pennsylvania (SE)

3. MacLachlan, D. B., 1979, Geology and mineral resources of the Temple and Fleetwood quadrangles, Berks County, Pennsylvania: Pennsylvania Geol. Survey, 4 th ser., Atlas $187 \mathrm{ab}$, p. $18-20$

4. Magnesian limestone, dolomite, chert

5. Dark- to medium-gray

6. $375 \mathrm{~m}$

7. Distinctive dark brownish chert fragments

9. Conformably overlies Muhlenberg Member (Allentown Formation); conformably underlies Stonehenge Formation (Beekmantown Group)

10. Type section: Exposures along Maiden Creek from Ontelaunee Reservoir to Schuylkill River, Berks County, Pa. 


\section{Maidens Gneiss}

1. Precambrian, late, and (or) Early Cambrian

2. Virginia (EC)

3. Poland, F. B., Glover, Lynn, III, and Mose, D. G., 1979, The geology of the rocks along the James River between Sabot and Cedar Point, Virginia, in Glover, Lynn, III, and Tucker, R. D., eds., Virginia Piedmont geology along the James River from Richmond to the Blue Ridge--Field trip 1, of Guides to field trips 1-3: Blacksburg, Va., Geol. Soc. America, Southeastern Sec., p. 11-13

4. Biotite gneiss, schist, quartzite

7. NNE-trending folds and W-facing overturned folds

9. Structurally overlies Sabot Amphibolite

10. Type area: Exposures along James River between State Farm and Cedar Point, Goochland County, Va. Named for village of Maidens.

\section{Makah Formation (Twin River Group)}

1. Eocene, late, to Oligocene (Narizian to Zemorrian)

2. Washington (NW)

3. Snavely, P. D., Jr., Niem, A. R., and Pearl, J. E., 1978, Twin River Group (upper Eocene to lower Miocene)--defined to include the Hoko River, Makah, and Pysht Formations, Clallam County, Washington: U.S. Geol. Survey Bull. 1457-A, p. A116-A117

4. Siltstone, sandstone, conglomerate, tuff, with calcareous concretions

6. $>2,800 \mathrm{~m}$

7. Thin- to thick-bedded, rhythmically bedded, deep-marginalbasin sequence, including turbidite sandstone packets and an olistostrome

8. [Six formal members of Snavely and others (1980): Baada Point, Dtokoah Point, Carpenters Creek Tuff, Klachopis Point, Third Beach, and Jansen Creek Members]

9. Gradationally or locally unconformably overlies Hoko River Formation; gradationally or locally unconformably underlies Pysht Formation

10. Type section: Shore cliffs and wave-cut platform exposures along Strait of Juan de Fuca from Waadah Island and Baada Point to Kydaka Point, Clallam County, Wash. Named for Makah Indian Reservation, NW Olympic Peninsula.

Malibu Bowl Tongue (Conejo Volcanics)

1. Miocene, middle

2. California (SC)

3. Yerkes, R. F., and Campbell, R. H., 1979, Stratigraphic nomenclature of the central Santa Monica Mountains, Los Angeles County, California: U.S. Geol. Survey Bull. 1457-E, p. E23

4. Andesitic and basaltic flows and flow breccias

6. $143 \mathrm{~m}$

9. Upper of three named tongues of Conejo Volcanics (Topanga Group), which are recognized only in upper plate of Malibu detachment fault. Overlies Dry Canyon Sandstone Member (Calabasas Formation) or Solstice Canyon Tongue (Conejo Volcanics); underlies and intertongues with Newell Sandstone Member (Calabasas Formation)

10. Type area: Malibu Bowl [populated place in SW1/4 sec. 23, 
T. 1 S., R. 18 w.J, Santa Monica Mountains, WC Malibu Beach quadrangle, Los Angeles County, Calif.

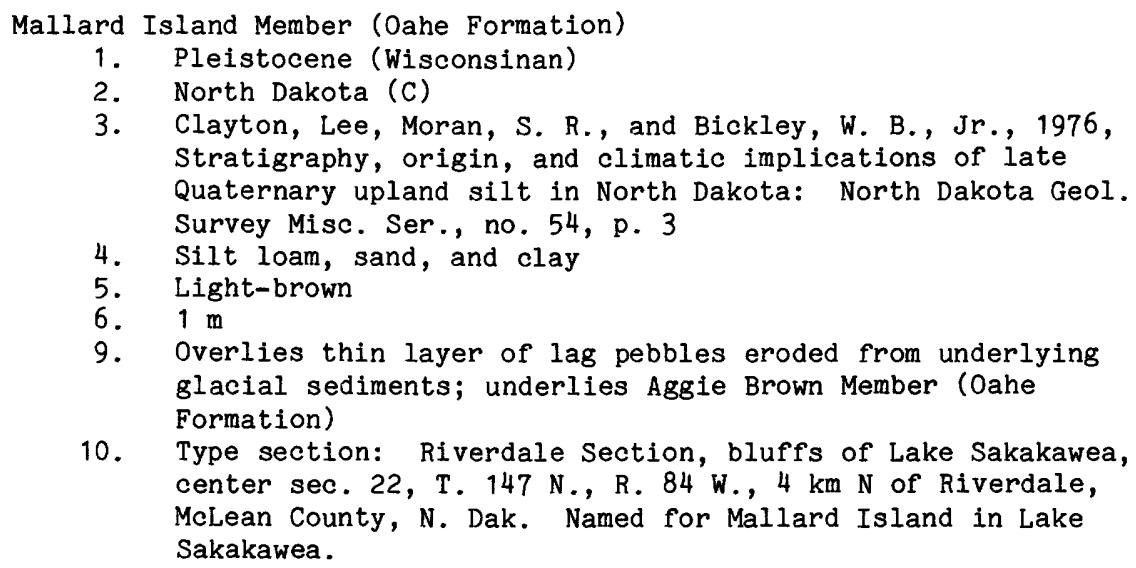

Marcella Formation

1. Late Mississippian

2. Arkansas (NC)

3. Ogren, D. E., 1968, Stratigraphy of Upper Mississippian rocks of northern Arkansas: Am. Assoc. Petroleum Geologists Bull., v. 52 , no. 2, p. 282-294

4. Calcarenite, limestone breccia, shale

5. Black, dark-gray

6. $71 \mathrm{~m}$

7. Thick-bedded, massive, fossiliferous

8. Wallace Creek Shale Member at base

9. Conformably overlies Pitkin Limestone; conformably and transitionally underlies Cane Hill Member (Hale Formation)

10. Type section: Exposure along intermittent tributary of Wallace Creek, NW1/4 sec. 12, T. 13 N., R. 9 W., near Marcella, Stone County, Ark.

Marco Junction Formation (Big Cypress Group)

1. Early Cretaceous (Comanchean)

2. Florida (SE)

3. Winston, G. D., 1976, Six proposed formations in the undefined portion of the Lower Cretaceous section in south Florida: Gulf Coast Assoc. Geol. Socs. Trans., v. 26, p. 71

4. Chalky limestone with dolomite and anhydrite beds

6. $101 \mathrm{~m}$

7. Dense limestone at base; thick, persistent anhydrite at top

9. Overlies Rattlesnake Hammock Formation (Ocean Reef Group); underlies Gordon Pass Formation (Big Cypress Group)

10. Type section: Humble No. 1 Collier Corp. well, depthinterval 3268-3369 m, sec. 27, T. 50 S., R. 26 E., Collier County, Fla. Named for Marco Junction, road junction $8 \mathrm{~km} \mathrm{~S}$ of type well.

Marshall Butte Member (Sheep Crossing Formation)

1. Miocene, middle and late

2. Arizona (EC)

3. Merrill, R. K., and Péwé, T. L., 1977, Late Cenozoic geology 
of the White Mountains, Arizona: Arizona Bur. Geology and Mineral Technology Spec. Paper 1, p. 18-19

4. Interbedded laharic breccia, sandstone, airfall tephra, diamicton mudflows

6. $65 \mathrm{~m}$

7. Debris flows deposited in colluvial fans; clasts throughout, including quartz latite boulders, are from lavas of Mount Baldy Volcano

9. Overlies Mount Baldy Formation; underlies Campground Member (Sheep Crossing Formation)

10. Type section: Lat 33048"30" N., long 109046"30" W., Corn Creek Plateau quadrangle, Apache County, Ariz. Named for Marshall Butte, hill on SW side of Mount Baldy, Marshall Butte quadrangle.

Marty Dolomite Bed (Flowerpot Shale)

1. Permian

2. Oklahoma (SC)

3. Johnson, K. S., 1976, Permian Copper Shales of southwestern Oklahoma, in Stratiform copper deposits of the midcontinent region, a symposium: Oklahoma Geol. Survey Circ. 77, p. 3-14

4. Dolomite

5. Light-gray, yellowish, tan

6. $0.15 \mathrm{~m}$, range $0.03-0.15 \mathrm{~m}$

7. Microgranular, platy, caps low escarpment, marker bed above copper shales

9. 7-8 $\mathrm{m}$ below top of Flowerpot Shale. Formerly considered equivalent to Kiser Gypsum Bed and referred to as Kiser Bed in Creta area

10. Type locality: W1/2 sec. 3, T. 1 S., R. 22 W., Jackson County, Okla. Named for exposures near Marty siding on railroad $\mathrm{E}$ of Creta.

\section{NeCully Formation}

1. Middle Pennsylvanian (Morrowan)

2. Oklahoma (EC)

3. Sutherland, P. K., and Henry, T. W., 1977, Carbonate platform facies and new stratigraphic nomenclature of the Morrowan Series (Lower and Middle Pennsylvanian), northeastern Oklahoma: Geol. Soc. America Bull., v. 88, no. 3, p. $432-435$

4. Shale, limestone

6. $19.5 \mathrm{~m}$, range $17.7-22.9 \mathrm{~m}$

8. Chisum Quarry Member, informal shale "A" member, Greenleaf Lake Limestone Member, informal shale " $B$ " member

9. Unconformably overlies Sausbee Formation; unconformably underlies Atoka Formation

10. Type section: Measured Section 1, W bluff of Arkansas River, 9-183 m S from $W$ end of Webbers Falls Lock and Dam, SW1/4SW1/4SE1/4 sec. 34, T. 13 N., R. 20 E., and Measured Section $3,0.5 \mathrm{~km}$ NW of MS 1 along river bluff, S1/2NW1/4SW1/4 sec. 34, T. 13 N., R. 20 E., Muskogee County, Okla. Probably named for exposures on McCully Mountain, bluff on $W$ side of Arkansas River $N$ of Webber Falls Lock and Dam. 
2. Michigan (EC)

3. Johnson, A. M., and others, 1979, The Maple Block knoll reef in the Bush Bay Dolostone (Silurian, Engadine Group), Northern Peninsula of Michigan: Michigan Univ. Mus. Paleontology Papers on Paleontology, no. 20, p. 18

4. Dolostone

5. Gray, mottled

6. $20 \mathrm{~m}$

7. Massive, vugular, medium- to coarsely crystalline, organic reef, fossil-rich reefal and fossil-poor interreefal facies

9. Overlies Swede Road Member; uppermost unit of Bush Bay Dolostone (Engadine Group), lies at surface or unconformably(?) underlies Pointe aux Chenes Formation (Salina Group)

10. Type section: Near McKay Bay along Michigan Route $134,5 \mathrm{~km}$ $\mathrm{E}$ of Cedarville, sec. 33, T. 42 N., R. 1 E., Mackinac County, Mich.

\section{Hesa Peak Breccia Member (Calabasas Formation)}

1. Miocene, middle

2. California (SC)

3. Yerkes, R. F., and Campbell, R. H., 1979, Stratigraphic nomenclature of the central Santa Monica Mountains, Los Angeles County, California: U.S. Geol. Survey Bull. 1457-E, p. E23

4. Breccia

6. $288 \mathrm{~m}$

7. Angular fragments of volcanic rock in very coarse grained sandstone

9. Conformably overlies Newell Sandstone Member (Calabasas Formation); upper contact not exposed [or may unconformably underlie Modelo Formation]; in fault contact with Sespe and Topanga Canyon Formations

10. Type locality: Mesa Peak, sec. 24, T. 1 S., R. 18 W., Santa Monica Mountains, WC Malibu Beach quadrangle, Los Angeles County, Calif.

Mesilla Valley Shale

1. Early Cretaceous

2. New Mexico (SC), Texas, Mexico

3. Strain, W. S., 1976, New formation names in the Cretaceous at Cerro de Cristo Rey, Doha Ana County, New Mexico,

Appendix 2, in Lovejoy, E. M. P., Geology of Cerro de Cristo Rey uplift, Chihuahua and New Mexico: New Mexico Bur. Mines and Mineral Resources Mem. 31, p. 80-81

4. Clay shale with limestone and siltstone beds

5. Olive-gray

6. $64 \mathrm{~m}$

7. Thin-bedded, fossiliferous

9. Conformably overlies Muleros Formation; conformably underlies Anapra Sandstone

10. Type section: $\mathrm{N}$ side of largest railroad cut in which $\mathrm{E}-$ bound traffic passes, NW1/4NW1/4NE1/4 sec. 16, T. $29 \mathrm{~S}$., R. 4 E., Smeltertown quadrangle, Dona Ana County, N. Mex. Named for Mesilla Valley, on Río Grande flood plain $\mathrm{N}$ of Cerro de Cristo Rey, Dona Ana County. 
2. Nevada (WC)

3. Speed, R. C., and Cogbill, A. H., 1979, Cenozoic volcanism of the Candelaria region, Nevada: Geol. Soc. America Bull., part 2, v. 90 , no. 2, p. 456-493

4. Ash-flow tuff

6. $70 \mathrm{~m}$

7. Basal zone moderately compacted, grading up to vitrophyre, strongly compacted upper zone vitric and stony

9. Unconformably overlies tuff unit 4; unconformably underlies tuff unit 6

10. Type locality: Cliff $2.5 \mathrm{~km} \mathrm{~S} .64^{\circ} \mathrm{W}$. of Metallic City site, Candelaria Hills, Mineral County, Nev.

\section{Mickey Pass Tuff}

1. Oligocene

2. Nevada (WC)

3. Proffett, J. M., Jr., and Proffett, B. H., 1976, Stratigraphy of the Tertiary ash-flow tuffs in the Yerington district, Nevada: Nevada Bur. Mines and Geology Rept. 27, p. $8-19$

4. Ash-flow tuffs with minor interbedded rhyolitic tuffs and sedimentary rocks

5. Brown, pink, lavender

6. $760 \mathrm{~m}$, range $760->900 \mathrm{~m}$

7. Two major ash-flow tuff cooling units with interbedded thin tuffs and sediments

8. Guild Mine Member, Weed Heights Member, and unnamed map units $4,5,7$

9. Unconformably overlies unnamed early Tertiary rocks; underlies Singatse Tuff

10. Type area: Exposures NE of Mickey Pass, SE1/4 sec. 13, T. $13 \mathrm{~N} .$, R. $24 \mathrm{E} .$, and SW1/4 sec. 18, T. 13 N., R. 25 E., Singatse Range, Lyon County, Nev.

\section{Middlesex Fells Volcanic Complex}

1. Precambrian(?)

2. Massachusetts (C)

3. Bell, K. G., and Alvord, D. C., 1976, Pre-Silurian stratigraphy of northeastern Massachusetts: Geol. Soc. America Mem. 148, p. 188-189, 199-201, app. 1 (in pocket)

4. Mafic flow rocks, pyroclastic deposits, and tuffs, all metamorphosed to amphibolite facies; minor quartzite and gneiss

5. Dark-gray to black

6. $15,000 \mathrm{~m}$

7. Fine-grained; thinly laminated lentils; pillow structures; ripple-bedding

9. Conformably overlies Westboro Formation; intruded by Dedham Granodiorite; unconformably underlies Greenleaf Mountain and Burlington Formation

10. Type locality: NW Middlesex Fells Reservation and NE into Wakefield, including High Rock hill, Boston North quadrangle, Middlesex County, Mass.

Millbrig Bentonite Bed (Glencoe Member of Spechts Ferry Formation)

1. Middle Ordovician

2. Illinois (NW), Wisconsin

3. Willman, H. B., and Kolata, D. R., 1978, The Platteville and Galena Groups in northern Illinois: Illinois Geol. Survey 
Circ. 502 , p. $43-44$

4. Bentonite clay

5. Light-gray, stained orange

6. $0.10 \mathrm{~m}$

9. At or near base of Glencoe Member, which overlies Castlewood Member (Spechts Ferry Formation)

10. Type section: Millbrig Southeast section, along $\mathrm{E}$ bank of Galena River, $1.6 \mathrm{~km}$ SE of Millbrig, center sec. 34, T. 29 N., R. 1 E., Jo Daviess County, Ill.

Mille Lacs Group

1. Precambrian, middle

2. Minnesota (C)

3. Morey, G. B., 1978, Lower and middle Precambrian stratigraphic nomenclature for east-central Minnesota: Minnesota Geol. Survey Rept. Inv. 21, p. 15-24

4. Metasedimentary arenitic quartz-rich rocks, metagraywacke, argillaceous, slate, dolomite, and metavolcanic rocks

6. $1,000 \mathrm{~m}$

8. Denham, Little Falls, Glen Township, and Randall Formations, and informal Trout Lake unit

9. Unconformably overlies McGrath Gneiss or early Precambrian gneissic rocks, undivided; unconformably underlies Animikie Group

10. Type area: Named for Mille Lacs Lake, Mille Lacs and Aitkin Counties, Minn. Type localities of its formations are in Pine, Aitkin, Morrison, and Crow Wing Counties.

Mina Formation

1. Permian

2. Nevada (WC)

3. Speed, R. C., 1977, Excelsior Formation, west-central Nevada--stratigraphic appraisal, new divisions, and paleogeographic interpretations, in Stewart, J. H., and others, eds., Paleozoic paleogeography of the western United States-Pacific Coast Paleogeography Symposium [Bakersfield, Calif., 1977]: Los Angeles, Soc. Econ. Paleontologists and Mineralogists, Pacific Sec., p. 328-332

4. Dominantly volcanogenic turbidite, lesser chert, pelite, and quartz sandstone

6. $>1,000 \mathrm{~m}$

7. Turbidite sequences fining upward; extensively thrustfaulted, forming nappes

9. Base not exposed; unconformably (angular) underlies Gold Range Formation

10. Type area: Lower Douglas Canyon, sec. 23, T. $6 \mathrm{~N}$., R. 34 E., Garfield Hills, 3-5 km SW of town of Mina, Mineral County, Nev.

Mixer Pond Member (Passagassawakeag Formation)

1. Precambrian

2. Maine (SC)

3. Bickel, C. E., 1976, Stratigraphy of the Belfast quadrangle, Maine: Geol. Soc. America Mem. 148, p. 103-104

4. Feldspathic gneiss composed of hornblende, biotite, ferrosalite, and magnetite

5. Light-gray, white

6. $300 \mathrm{~m}$ 
7. Fine-grained, massive, compositionally layered

9. Unconformably underlies Hogback Schist

10. Type locality: Near Mixer Pond, Belfast quadrangle, Waldo County, Maine.

Mobile Clay

1. Miocene, middle

2. Alabama (SW)

3. Isphording, W. C., 1977, Petrology and stratigraphy of the Alabama Miocene: Gulf Coast Assoc. Geol. Socs. Trans., v. 27, p. $305-306$

4. Clay

5. Dark-green, lavender, gray, brassy-yellow

6. $<450 \mathrm{~m}$

7. Laminated to massive, marine and transitional-marine deposit, fossiliferous

9. Overlies Chickasawhay Limestone or (downdip to S) Tampa Limestone; underlies Ecor Rouge Sand

10. Type area: Along Mobile River, highways, and in gravel pits in Mobile County, Ala.

\section{Hoffett Creek Formation}

1. Silurian or older

2. California (NW)

3. Hotz, P. E., 1977, Geology of the Yreka quadrangle, Siskiyou County, California: U.S. Geol. Survey Bull. 1436, p. 25-30

4. Sandstone or siltstone blocks in matrix of shale

5. Medium-gray to dark-greenish-gray

7. Strongly sheared; olistostrome or broken formation

9. In thrust contact with underlying Duzel Phyllite and Schulmeyer Gulch sequence, and with overlying Sissel Gulch Graywacke

10. Type locality: Moffett Creek, sec. 12, T. 43 N., R. 8 W., Siskiyou County, Calif.

Moore Hollow Group

1. Middle Cambrian to Early Ordovician

2. Texas (C)

3. Barnes, V. E., and Bell, W. C., 1977, The Moore Hollow Group of central Texas: Texas Bur. Econ. Geology Rept. Inv. 88, 169 p.

4. Limestone, dolomite, sandstone, quartz sand, glauconite

5. Gray

6. Range $180-540 \mathrm{~m}$

7. Granular limestone, fine-grained dolomite, fossiliferous

8. Riley Formation and its Hickory Sandstone, Cap Mountain Limestone, and Lion Mountain Sandstone Members; and Wilberns Formation and its Welge Sandstone, Morgan Creek Limestone, Point Peak, and San Saba Members

9. Unconformably overlies Precambrian rocks; conformably underlies Tanyard Formation (Ellenburger Group)

10. Type locality: East Canyon, just $S$ of Moore Hollow, SE Riley Mountains, Llano County, Tex.

Moore House Hember (Yorktown Formation)

1. Pliocene, early

2. Virginia (SE)

3. Ward, L. W., and Blackwelder, B. W., 1980, Stratigraphic 
revision of upper Miocene and lower Pliocene beds of the Chesapeake Group, middle Atlantic Coastal Plain: U.S. Geol. Survey Bull. 1482-D, p. D43-D48

4. Clayey sand, shell hash

5. Tan, orange

6. $4 \mathrm{~m}$, range $4-6 \mathrm{~m}$

7. Locally cemented, cross-bedded

9. Conformably overlies Morgarts Beach Member; upper contact not exposed, or underlies upper Pliocene or Pleistocene deposits

10. Type section: Bluffs at Moore House, S bank of York River, Yorktown Battlefield Park, York County, Va.

Moose Channel Formation

1. Late Cretaceous and Paleocene

2. Canada (District of Mackenzie), Alaska

3. Mountjoy, E. W., 1967, Upper Cretaceous and Tertiary stratigraphy, northern Yukon Territory and northwestern District of Mackenzie: Canada Geol. Survey Paper 66-16, p. 8-9. Geographically extended to Alaska in: Lyle, W. M., and others, 1980, Post-Early Triassic formations of northeastern Alaska and their petroleum reservoir and source-rock potential: Alaska Div. Geol. and Geophys. Surveys Geol. Rept. 76 , p. 6

4. Feldspathic, laminated sandstone interbedded with silty shale and conglomerate lenses

5. Greenish-gray to brown

6. $365 \mathrm{~m}$

7. Nonmarine, contains plant fragments and coal seams, loosely consolidated

9. Overlies Upper Cretaceous shale; unconformably underlies Pleistocene and Holocene deposits

10. Type locality: Exposures along Fish River, on W side of Mackenzie Delta, Canada. Named for Moose Channel, lat $68^{\circ} 43^{\prime} \mathrm{N} .$, long $136^{\circ} 23^{\prime} \mathrm{W}$.

Morgarts Beach Member (Yorktown Formation)

1. Pliocene, early

2. Virginia (SE), North Carolina

3. Ward, L. W., and Blackwelder, B. W., 1980, Stratigraphic revision of upper Miocene and lower Pliocene beds of the Chesapeake Group, middle Atlantic Coastal Plain: U.S. Geol. Survey Bull. 1482-D, p. D40-D43

4. Sandy to silty clay

5. Gray

6. $3 \mathrm{~m}$, range $3-6 \mathrm{~m}$

7. Fine-grained, fossiliferous

9. Conformably overlies Rushmere Member; conformably underlies Moore House Member

10. Type section: Exposures $1 \mathrm{~km}$ below Morgarts Beach, $\mathrm{R}$. bank of James River, Isle of Wight County, Va. Named for beds at Morgarts Beach.

Houltrie Member (Santee Limestone)

1. Eocene, middle (Claibornian)

2. South Carolina (C)

3. Ward, L. W., and others, 1979, Stratigraphic revision of Eocene, Oligocene, and lower Miocene formations of South 
Carolina: South Carolina Geol. Survey Geol. Notes, v. 23, no. 1, p. 5-9

4. Calcirudite and biosparrite

5. Light-gray

6. $6 \mathrm{~m}$

7. Fossiliferous (bryozoan biosparrite, bivalvemolds), indurated; phosphate-coated, burrowed upper surface

9. Overlies Black Mingo Formation [subsurface]; unconformably underlies Cross Member (Santee Limestone)

10. Type section: Section at Martin Marietta Co. Berkeley quarry, $2.4 \mathrm{~km} \mathrm{~S}$ of Route 6 and Route 59 intersection, Chicora 15' quadrangle, Berkeley County, S.C. Named for nearby Lake Moultrie.

Mount Baldy Formation

1. Miocene

2. Arizona (EC)

-3. Merrill, R. K., and Péwé, T. L., 1977, Late Cenozoic geology of the White Mountains, Arizona: Arizona Bur. Geology and Mineral Technology Spec. Paper 1, p. 9-17

4. Latite, quartz latite, alkali trachyte, and rhyolite flows

5. Light-gray, grayish-red to bluish-gray

6. $<500 \mathrm{~m}$

7. Lava flows erupted from Mount Baldy Volcano; platy or blocky jointing

8. Informal lower and upper members

9. Overlies early volcanic and volcaniclastic rocks of middle Tertiary age; underlies Sheep Crossing Formation or lies at surface

10. Type locality: Along ridge between East Fork of Little Colorado River and West Fork of Black River, Apache County, Ariz. Named for Mount Baldy, which includes Baldy Peak, highest peak of White Mountain Massif.

Mount Baldy Rhyolite Member (Mount Belknap Volcanics)

1. Miocene

2. Utah (SC)

3. Steven, T. A., and others, 1979, Revised stratigraphy and radiometric ages of volcanic rocks and mineral deposits in the Marysvale area, west-central Utah: U.S. Geol. Survey Bull. 1469, p. 29

4. Rhyolite

5. Light-gray to white

6. $300 \mathrm{~m}$

7. Fine-grained, locally prominent, contorted lava flows

9. Overlies Blue Lake Rhyolite Member or unnamed middle tuff or sedimentary breccia members; units are part of intracaldera facies of Mount Belknap Volcanics

10. Type area: Exposures on cliffs forming upper slopes of Mount Baldy, Piute County, Utah.

Mount Blue Member (Seboomook Formation)

1. Early Devonian

2. Maine (WC)

3. Pankiwskyj, K. A., 1979, Bedrock geology of the Kingfield and Anson 15' quadrangles, Franklin and Somerset Counties, Maine: Maine Geol. Survey Geol. Map Series GM-7, 51 p.

4. Metasiltstone and metapelite 
5. Gray

6. $1,000 \mathrm{~m}$

7. Rhythmically bedded, rusty-weathering

9. Overlies Hildreth Formation; gradationally underlies Temple Stream Member (Seboomook Formation)

10. Type locality: Summit of Mount Blue, N Dixfield quadrangle, Franklin County, Maine.

Mount Emily Dacite

1. Oligocene, middle

2. Oregon (SW)

3. Beaulieu, J. D., and Hughes, P. W., 1976, Land use geology of western Curry County, Oregon: Oregon Dept. Geology and Mineral Industries Bull. 90, p. 20-21, 52

4. Dacite, diorite, syenite

5. Light-colored

7. Two large intrusive bodies form prominent mountain with radiating dike ridges

9. Intrusive into Dothan Formation

10. Type area: Mount Emily, Mount Emily quadrangle, Curry County, Oreg.

Mount Galen Volcanics

1. Eocene, late, and oligocene, early

2. Alaska (C)

3. Decker, J. E., and Gilbert, W. G., 1978, The Mount Galen Volcanics--a new middle Tertiary volcanic formation in the central Alaska Range: Alaska Geol. and Geophys. Surveys Geol. Rept. 59, p. 1-11

4. Andesitic and basaltic breccia, lava flows, tuff

6. $>1,000 \mathrm{~m}$

9. Unconformably overlies Cantwell Formation; as possible eruptive center, cuts Triassic(?) metabasalt; conformably underlies Tertiary lignite-bearing sedimentary rocks

10. Type locality: Narrow ridge extending from Stony Creek SW to top of Mount Galen in Mount McKinley B-1 quadrangle, Mount McKinley National Park, WC Alaska Range, Alaska.

\section{Hount Laird Tuff}

1. Eocene, late

2. Utah (WC)

3. Lindsey, D. A., 1979, Geologic map and cross-sections of Tertiary rocks in the Thomas Range and northern Drum Mountains, Juab County, Utah: U.S. Geol. Survey Misc. Inv. Ser. Map I-1176

4. Rhyodacite to quartz latite ash-flow tuff, with crystals of plagioclase, biotite, horneblende, and pyroxene

5. Pink

6. $80 \mathrm{~m}$, range $80-500 \mathrm{~m}$

9. Overlies Drum Mountains Rhyodacite; unconformably underlies Joy Tuff

10. Type locality: Exposures near Mount Laird in Drum Mountains, secs. 23 and 26, T. 14 S., R. 11 W., Juab County, Utah. 
3. Axelrod, D. I., 1980, Contributions to the Neogene paleobotany of central California: California Univ. Pubs. Geol. Sci., v. 121, p. 25

4. Boulder conglomerate

6. $24 \mathrm{~m}$

7. Poorly lithified

9. Unconformably overlies Disaster Peak Formation or Relief Peak Formation; youngest Tertiary unit in area

10. Type locality: Ridge $\mathrm{E}$ of Mount Reba, Alpine County, Calif.

\section{Mount Sheridan Gabbro (Roosevelt Gabbros)}

1. Cambrian

2. Oklahoma (C)

3. Powell, B. N., Gilbert, M. C., and Fischer, J. F., 1980, Lithostratigraphic classification of basement rocks of the Wichita province, Oklahoma: Summary: Geol. Soc. America Bull., pt. 1, v. 91, no. 9, p. 510-513

4. Biotite gabbro grading upward into ferrogranodiorite

5. Dark-gray, weathers reddish brown

6. $>200 \mathrm{~m}$

7. Medium-grained, hypidiomorphic, sill-like intrusive body

9. Intrusive into Glen Mountains Layered Complex (Raggedy Mountain Gabbro Group); intruded by Mount Scott Granite

10. Type locality: $\mathrm{N}$ and $\mathrm{E}$ slopes of Mount Sheridan, NE1/4 and SE1/4 sec. 5, T. 3 N., R. 13 W., Wichita Mountains, Comanche County, Okla.

Mount Washington Amphibolite (Baltimore Mafic Complex)

1. Cambrian(?)

2. Maryland (NC)

3. Crowley, W. P., 1976, The geology of the crystalline rocks near Baltimore and its bearing on the evolution of the eastern Maryland Piedmont: Maryland Geol. Survey Rept.

Inv. 27, p. 14, 28-30

4. Plagioclase, amphibole

5. Dark-green to black

7. Fine- to medium-grained, massive

9. In thrust-fault contact with Loch Raven Schist, Oella and Sykesville Formations (Wissahickon Group); overlies Hollofield Layered Ultramafite (Baltimore Mafic Complex) in $\mathrm{E}-\mathrm{W}$ anticline which is truncated on $\mathrm{SE}$ by James Run Formation

10. Type locality: Outcrops along unnamed S-flowing tributary of Western Run near intersection where Cross Country Boulevard becomes Kelly Avenue, Mount Washington section of Baltimore City, Baltimore County, Md.

Mud Springs Canyon Formation

1. Late Triassic and Early Jurassic(?)

2. Nevada (WC)

3. Speed, R. C., 1976, Geologic map of the Humboldt lopolith and surrounding terrane, Nevada: Geol. Soc. America Map and Chart Ser. MC-14, p. 2

4. Limestone, dolomite, minor quartz sandstone

6. $600 \mathrm{~m}$

7. Massive- to medium-bedded, fossiliferous

9. Conformably overlies Hoyt Canyon Formation; unconformably underlies Boyer Ranch Formation 
10. Type locality: Not stated. Probably named for exposures near Mud Spring Creek, secs. 35 and 36, T. 23 N., R. 37 E., Clan Alpine Mountains, Churchill County, Nev.

Muhlenberg Member (Allentown Formation)

1. Late Cambrian

2. Pennsylvania (SE)

3. MacLachlan, D. B., 1979, Geology and mineral resources of the Temple and Fleetwood quadrangles, Berks County, Pennsylvania: Pennsylvania Geol. Survey, 4 th ser., Atlas 187ab, p. $15-18$

4. Limestone, dolomite, sandstone

5. Gray

6. $240 \mathrm{~m}$

7. Sandy and carbonate fragments abundant in soil, stromatolitic, oolitic, cyclic deposits

9. Conformably overlies Tuckerton Member; conformably underlies Maiden Creek Member

10. Type locality: Temple quarry of Berks Products Corp., Muhlenberg Township, Temple quadrangle, Berks County, Pa.

Muleros Formation

1. Early Cretaceous

2. New Mexico (SC), Texas, Mexico

3. Strain, W. S., 1976, New formation names in the Cretaceous at Cerro de Cristo Rey, Doha Ana County, New Mexico,

Appendix 2, in Lovejoy, E. M. P., Geology of Cerro de Cristo Rey uplift, Chihuahua and New Mexico: New Mexico Bur. Mines and Mineral Resources Mem. 31, p. 79-80

4. Limestone, interbedded with shale and siltstone

5. Olive-gray, yellowish-brown

6. $32.4 \mathrm{~m}$

7. Limestone nodular, fossiliferous (Texigryphaea in banklike layers)

9. Conformably overlies Smeltertown Formation; conformably underlies Mesilla Valley Shale

10. Type section: On $\mathrm{N}$ side near head of arroyo trending $\mathrm{S}$ $70^{\circ} \mathrm{W}$ from kiln area of El Paso Brick Co. plant; SE1/4SE1/4NE1/4 sec. 16, T. 29 S., R. 4 E., Smeltertown quadrangle, Dona Ana County, N. Mex. Named for Cerro de Muleros, original name of Cerro de Cristo Rey.

Mullikin Brook Member (Ammonoosuc Formation)

1. Middle Ordovician

2. New Hampshire (WC)

3. Prager, G. D., 1980, Stratigraphy of the Gardner Mountain area, New Hampshire: Northeastern Geology, v. 2, no. 1, p. 34

4. Quartz- and sericite-rich felsite

7. Massive, fine-grained, granular

9. Underlies West Bath Member

10. Type locality: Mullikin Brook, $0.24 \mathrm{~km} \mathrm{~S}$ of New Hampshire Route 18, Grayton County, N.H.

Muncy Till

1. Pleistocene (Illinoian)

2. Pennsylvania (C)

3. Wells, R. B., and Bucek, M. F., 1980, Geology and mineral 
resources of the Montoursville North and Huntersville quadrangles, Lycoming County, Pennsylvania: Pennsylvania

Geological Survey, 4 th ser., Atlas $143 \mathrm{~cd}$, p. 24,61

4. Slightly calcareous till consisting of clay, silt, sand, and pebbles

5. Dark-grayish-brown

6. $12.19 \mathrm{~m}$

7. Well-compacted, unsorted and nonstratified

9. Overlies Muncy drift and Paleozoic bedrock; underlies Warrensville Till and drift

10. Type section: Roadcut on U.S. Route $220,8 \mathrm{~km}$ NW of Muncy, lat $40^{\circ} 15^{\prime} 10^{\prime \prime} \mathrm{N}$., long $76^{\circ} 52^{\prime} 29^{\prime \prime} \mathrm{W}$., Montoursville North quadrangle, Lycoming County, Pa.

\section{Murdock Mountain Formation (Park City Group)}

1. Early Permian (Roadian to Wordian)

2. Nevada (NE), Utah

3. Wardlaw, B. R., Collinson, J. W., and Maughan, E. K., 1979, The Murdock Mountain Formation--a new unit of the Permian Park City Group, Chapter B, in Wardlaw, B. R., ed., Studies of the Permian Phosphoria Formation and related rocks, Great Basin-Rocky Mountain region: U.S. Geol. Survey Prof. Paper $1163-B$, p. 5-8

4. Dolomitic chert, dolomite, sandstone, siltstone

5. Gray

6. $385.5 \mathrm{~m}$

7. Bedded, fossiliferous, slope- and ledge-forming

9. Conformably and gradationally overlies Meade Peak Phosphatic Shale Tongue (Phosphoria Formation); conformably underlies Gerster Limestone (Park City Group)

10. Type section: On E flank of Murdock Mountain, N-center sec. 36, T. 39 N., R. 67 E., Leach Mountains, Loray quadrangle, Elko County, Nev.

Murphy Member (Snake Creek Formation)

1. Miocene, middle

2. Nebraska (NW)

3. Skinner, M. F., Skinner, S. M., and Gooris, R. J., 1977, Stratigraphy and biostratigraphy of late Cenozoic deposits in central Sioux County, western Nebraska: Am. Mus. Nat. History Bull., v. 158, art. 5, p. 308-310

4. Sand, sandy clay, basal conglomerate

5. Pink, tan, gray

6. $\quad 9.7 \mathrm{~m}$, range $4.8-9.7 \mathrm{~m}$

7. Consolidated, channel deposit, fossiliferous (vertebrates)

9. Disconformably overlies Olcott Formation or Sheep Creek Formation (Hemingford Group); unconformably underlies Laucomer Member or Johnson Member (Snake Creek Formation)

10. Type section: NE side of olcott Hill, NE1/4SW1/4SE1/4 sec. 3, T. 25 N., R. 55 W., near Murphy Ranch, Sioux County, Nebr.

\section{Musinia Peak Member (Flagstaff Limestone)}

1. Eocene, early

2. Utah (C)

3. Stanley, K. O., and Collinson, J. W., 1979, Depositional history of Paleocene-lower Eocene Flagstaff Limestone and coeval rocks, central Utah: Am. Assoc. Petroleum Geologists 
Bull., v. 63 , no. 3, p. 318-319

4. Limestone (micrite), interbedded with mudstone

5. Bluish-gray, yellowish-brown

6. $37 \mathrm{~m}$, range $37-50 \mathrm{~m}$

7. Fossiliferous (mollusks); represents upper of two major high stands of Lake Flagstaff

9. Overlies Cove Mountain Member (Flagstaff Limestone); upper contact nowhere exposed on top of Wasatch Plateau, but on $W$ flank conformably underlies Colton Formation

10. Type locality: Musinia Peak, E1/2 sec. 28, T. 20 S., R. 3 E., Wasatch Plateau, Sanpete County, Utah.

Muzzy Ridge Member (Appleton Ridge Formation)

1. Early Devonian

2. Maine (SC)

3. Bickel, C. E., 1976, Stratigraphy of the Belfast quadrangle, Maine: Geol. Soc. America Mem. 148, p. 109

4. Cummingtonite-garnet schist with minor biotite, plagioclase, quartz, and hornblende

5. Gray to black, weathers rusty

7. Fine-grained, dense; weakly schistose

9. In fault contact with Jam Brook Formation to SW along St. George fault

10. Type locality: Muzzy Ridge, Belfast quadrangle, Waldo County, Maine.

Nagog Pond Gneiss Member (Nashoba Formation)

1. pre-Silurian

2. Massachusetts (C)

3. Bell, K. G., and Alvord, D. C., 1976, Pre-Silurian stratigraphy of northeastern Massachusetts: Geol. Soc. America Mem. 148, p. 184-185, 208, app. 1 (in pocket)

4. Sillimanitic biotite gneiss

5. Medium-gray

6. $1,370 \mathrm{~m}$

7. Medium-grained, stratified, relict sedimentary structures

9. Overlies Nashoba Brook Member; underlies Fort Pond Member

10. Type locality: Area bounded on NW by Nagog Pond, on SW by Nagog Brook, on SE by S-flowing tributary to Nagog Brook, and on NE by Great Road, all in town of Acton, Westford quadrangle, Middlesex County, Mass.

Nashoba Brook Nember (Nashoba Formation)

1. pre-Silurian

2. Massachusetts (C)

3. Bell, K. G., and Alvord, D. C., 1976, Pre-Silurian stratigraphy of northeastern Massachusetts: Geol. Soc. America Mem. 148, p. 186-187, 208, app. 1 (in pocket)

4. Calc-silicate rocks, sillimanitic muscovite-biotite schist, amphibole-biotite gneiss

6. $920 \mathrm{~m}$

7. Stratified, relict sedimentary structures

9. Overlies Tophet Swamp Gneiss Member; underlies Nagog Pond Gneiss Member

10. Type locality: Outcrops near junction of Quarry Road and Main Street in town of North Acton, and along Nashoba Brook $E$ of this junction, Westford quadrangle, Middlesex County, Mass. 
Nasset Bentonite Bed (Sherwood Member of Dunleith Formation)/(Loves Park Member of Dunleith Formation, in Illinois only)

1. Middle Ordovician

2. Iowa (NE), Illinois

3. Willman, H. B., and Kolata, D. R., 1978, The Platteville and Galena Groups in northern Illinois: Illinols Geol. Survey Circ. 502 , p. 50

4. Bentonite clay

6. $0.07 \mathrm{~m}$

9. In type section, overlies and underlies limestone units in lower part of Sherwood Member

10. Type section: Engineers old Cut section, stream diversion channel, $2.4 \mathrm{~km} \mathrm{~W}$ of Decorah, SE1/4NE1/4 sec. 18, T. $98 \mathrm{~N}$., R. 8 W., Winneshiek County, Iowa. Named for town of Nasset, $12.8 \mathrm{~km} \mathrm{E}$ of type section.

\section{Hewell Sandstone Member (Calabasas Formation)}

1. Miocene, middle

2. California (SC)

3. Yerkes, R. F., and Campbell, R. H., 1979, Stratigraphic nomenclature of the central Santa Monica Mountains, Los Angeles County, California: U.S. Geol. Survey Bull. 1457-E, p. E23

4. Sandstone, shaly siltstone, dolomitic concretions in siltstone

6. $244 \mathrm{~m}$

7. Poorly sorted turbidites

9. Conformably overlies Dry Canyon Sandstone Member (Calabasas Formation); intertongues with Malibu Bowl Tongue (Conejo Volcanics); conformably underlies Mesa Peak Breccia Member (Calabasas Formation)

10. Type area: Newell Road, Santa Monica Mountains, WC Malibu Beach quadrangle, Los Angeles County, Calif.

Newfound Member (Doswell Formation)

1. Late Triassic

2. Virginia (EC)

3. Weems, R. E., 1980, Geology of the Taylorsville basin, Hanover County, Virginia: Virginia Div. Mineral Resources Pub. 27, p. 26-27

4. Sandstone-conglomerate facies intertonguing with sandstonesiltstone facies

5. Light-brown, light-gray, grayish-orange, red

6. $\quad 513.3 \mathrm{~m}$

7. Massive, crossbedded, alluvial-fan, fluvial, flood-plain deposits

9. Conformably overlies Falling Creek Member (Doswell Formation); unconformably underlies Miocene to Holocene strata

10. Type section: Along Stagg Creek, beginning at Hanover Country Club, $0.3 \mathrm{~km} \mathrm{~N}$ of Virginia Highway 54 and continuing $S$ to contact with Petersburg Granite, Taylorsville basin, Hanover Academy quadrangle, Hanover County, Va. Named for Newfound River, tributary of South Anna River.

New Hanover Member (Castle Hayne Formation)

1. Eocene, middle (Claibornian)

2. North Carolina (SE)

3. Ward, L. W., Lawrence, D. R., and Blackwelder, B. W., 1978, 
Stratigraphic revision of the middle Eocene, Oligocene, and lower Miocene--Atlantic Coastal Plain of North Carolina: U.S. Geol. Survey Bull. 1457-F, p. F6-F8

4. Phosphatic 11thocalcirudite

5. Cream-colored matrix

6. $1 \mathrm{~m}$, range $<1-2 \mathrm{~m}$

7. Arenitic, micrite matrix; cobble- to pebble-sized clasts; fossiliferous

9. Unconformably overlies and occupies erosional channels in Peedee Formation; unconformably underlies Comfort Member (Castle Hayne Formation)

10. Type locality: Martin Marietta Co. Castle Hayne quarry, $28 \mathrm{~km} \mathrm{E}$ of Castle Hayne, $0.8 \mathrm{~km}$ north of County Route 1002 , New Hanover County, N.C.

New Harmony Group

1. Early Devonian

2. Illinois (SE), Indiana

3. Becker, L. E., and Droste, J. B., 1978, Late Silurian and Early Devonian sedimentologic history of southwestern Indiana: Indiana Geol. Survey Occasional Paper 24, p. 4-5

4. Dolomitic limestone and chert

6. $150 \mathrm{~m}$

7. Medium- to coarse-grained

8. Backbone Limestone, Grassy Knob Chert, Clear Creek Chert

9. Conformably overlies Bailey Limestone (Bainbridge Group); unconformably underlies Dutch Creek Sandstone Member (Jeffersonville Limestone)

10. Type section: Superior No. C-17 Ford well, depth-interval 1520-1670 m, sec. 27, T. 4 S., R. 14 W., White County, I11. Named for town of New Harmony, Ind., across Wabash River from well.

New Shoreham Drift

1. Pleistocene (late Wisconsinan)

2. Rhode Island (SC)

3. Sirkin, Les, 1976, Block Island, Rhode Island--evidence of fluctuation of the late Pleistocene ice margin: Geol. Soc. America Bull., v. 87, no. 4, p. 574-580

4. Sand and gravel outwash overlain by till

6. $20 \mathrm{~m}$

7. Cross-bedded; morainal topography and drumlin field; derived from glacial lobe that crossed Connecticut region

9. Unconformably overlies Montauk Drift and interstadial alluvium deposits

10. Type section: Not stated. Derivation of name not stated. occurs on Block Island, R.I.

New Sweden Formation (Perham Group)

1. Silurian (Llandoverian and Wenlockian)

2. Maine (NE)

3. Roy, D. C., and Mencher, Ely, 1976, Ordovician and Silurian stratigraphy of northeastern Aroostook County, Maine: Geol. Soc. America Mem. 148 , p. 38, 49

4. Calcareous, phyllitic slate containing laminae of calcareous siltstone and manganiferous ironstone

5. Gray

6. Range $180-1,200 \mathrm{~m}$ 
9. Conformably overlies Spragueville Formation or Carys Mills Formation, or disconformably overlies Pyle Mountain Argillite; interfingers with Spragueville Formation or Frenchville Formation; conformably underlies Jemtland Formation (Perham Group)

10. Type area: Exposed along Maine Route 161 in New Sweden, Aroostook County, Maine.

\section{Mine Hill Tuff}

1. Oligocene

2. Nevada (WC)

3. Bingler, E. C., 1978, Abandonment of the name Hartford Hill Rhyolite Tuff and adoption of new formation names for middle Tertiary ash-flow tuffs in the Carson City-Silver City area, Nevada: U.S. Geol. Survey Bull. 1457-D, p. D11-D14

4. Ash-flow tuff

5. Pale-orange-red to reddish-purple in lower part; pale-brown to purplish-brown in upper part

6. $>700 \mathrm{~m}$

7. Devitrified, densely welded, pumice-rich in lower part; vitric, weakly welded, pumice-poor in upper part, which locally includes dikes and pluglike masses of very densely welded and stretched tuff

9. Unconformably overlies pre-Tertiary basement rocks and Mickey Pass Tuff; disconformably underlles Eureka Canyon Tuff and younger Tertiary volcanic rocks; younger than Lenthan Canyon Tuff

10. Type section: Near Nine Hill, NE1/4 sec. 29, T. 16 N., R. 20 E., Carson City quadrangle, Washoe County, Nev.

North Standard Latite (Laguna Springs Volcanic Group)

1. Oligocene, middle

2. Utah (C)

3. Morris, H. T., and Lovering, T. S., 1979, General geology and mines of the East Tintic mining district, Utah and Juab Counties, Utah: U.S. Geol. Survey Prof. Paper 1024, p. 45,48

4. Latite flows, tuff, alluvium

5. Tuff: gray to white; flow: purplish-gray

6. Tuff: irregular thickness; flow: $91-152 \mathrm{~m}$

7. Tuff: heterogeneous boulder tuff; flow: medium-grained latite vitrophyre

8. Informal lower tuff member, upper flow member

9. Unconformably overlies Latite Ridge Latite (Tintic Mountain Volcanic Group), Packard Quartz Latite, or Paleozoic rocks; underlies Pinyon Queen Latite (Laguna Springs Volcanic Group)

10. Type locality: Outcrops in area of North Standard shaft, secs. 27 and 34, T. 9 S., R. 2 W., East Tintic mining district, Utah County, Utah.

Nugent Tuff Member (Hu-pwi Rhyodacite)

1. Miocene

2. Nevada (WC)

3. Ekren, E. B., 1980, Stratigraphy, preliminary petrology, and some structural features of Tertiary volcanic rocks in the Gabbs Valley and Gillis Ranges, Mineral County, Nevada: U.S. Geol. Survey Bull. 1464, p. 37-38 
4. Rhyodacitic ash-flow tuff

5. Gray, brown

6. Range $<1-500 \mathrm{~m}$

7. Porphyritic, compound cooling unit

9. Overlies Blue Sphinx Tuff or lava of Nugent Wash; underlies Ghost Dance Lava Member or Poinsettia Tuff Member (Hu-pwi Rhyodacite), or younger lavas or tuffs

10. Type locality: Exposures in and near Nugent Wash, T. $11 \mathrm{~N}$., R. 32 E., N Gabbs Valley Range, Mineral County, Nev.

Oahe Formation

1. Pleistocene (Wisconsinan) and Holocene

2. North Dakota (C)

3. Clayton, Lee, Moran, S. R., and Bickley, W. B., Jr., 1976, Stratigraphy, origin, and climatic implications of late Quaternary upland silt in North Dakota: North Dakota Geol. Survey Misc. Ser., no. 54, p. 1-15

4. Unlithified silt loam composed of silt, clay, and sand

5. Light-gray, light-brown

6. $\quad 3.10 \mathrm{~m}$, range $3.10-6 \mathrm{~m}$

7. Unbedded; vertical columnar jointing; fossiliferous

8. Mallard Island, Aggie Brown, Pick City, Riverdale Members

9. Overlies glacial sediments; lies at surface

10. Type section: Riverdale Section, bluffs of Lake Sakakawea, center sec. 22, T. $147 \mathrm{~N}$., R. $84 \mathrm{~W}, 4 \mathrm{~km} \mathrm{~N}$ of Riverdale, McLean County, N. Dak. Named for Oahe Reservoir, Emmons County.

Oak City Formation

1. Miocene

2. Utah (C)

3. Campbell, J. A., 1979, Middle to late Cenozoic stratigraphy and structural development of the Canyon Range, central

Utah: Utah Geology, v. 6, no. 1, p. 8-13

4. Conglomerate, sandstone, and siltstone

5. Pinkish-gray

6. $45 \mathrm{~m}$

7. Bedded, coarse- to fine-grained. Remnants of extensive alluvial fan deposits

9. Unconformably overlies folded, faulted, and deeply eroded early Paleozoic and Tertiary strata; surface is maturely dissected and covered by mantle of lag gravel

10. Type locality: Exposures on SW facing slope between Oak City and Clay Spring Wash, SE1/4NW1/4NW1/4 sec. 20, T. 17 S., R. 4 W., Canyon Range, Millard County, Utah.

Oella Formation (Wissahickon Group)

1. Cambrian-Ordovician(?)

2. Maryland (NC)

3. Crowley, W. P., 1976, The geology of the crystalline rocks near Baltimore and its bearing on the evolution of the eastern Maryland Piedmont: Maryland Geol. Survey Rept. Inv. 27, p. 11, 24-25

4. Biotite-plagioclase-muscovite quartz schist, interlayered with biotite-plagioclase-quartz gneiss and, locally, epidote amphibolite

6. Range $<1-1,300 \mathrm{~m}$

8. Locally divisible into lower unnamed metasedimentary unit, 
and (upper) Sweathouse Amphibolite Member

9. Overlies Loch Raven Schist; underlies Sykesville Formation

10. Type locality: Outcrops along Patapsco River at 0ella, SW Baltimore County, Md.

Olcott Formation (Hemingford Group)

1. Miocene, middle

2. Nebraska (NW)

3. Skinner, M. F., Skinner, S. M., and Gooris, R. J., 1977, Stratigraphy and biostratigraphy of late Cenozoic deposits in central Sioux County, western Nebraska: Am. Mus. Nat. History Bull., v. 158, art. 5, p. 300-306

4. Quartz sand, silty sand, sandy ash

5. Buff, brown, gray

6. $24 \mathrm{~m}$

7. Fluviatile, massive, well-sorted, fossiliferous (vertebrates)

9. Unconformably overlies Harrison Formation (Arikaree Group) or, locally, Sheep Creek Formation (Hemingford Group); disconformably underlies Snake Creek Formation (Ogallala Group)

10. Type section: NE side of olcott Hill, NW/14SE1/4SE1/4 sec. 3, T. 25 N., R. 55 W., Sioux County, Nebr.

Olema Creek Formation

1. Pleistocene

2. California (WC)

3. Galloway, A. J., 1977, Geology of the Point Reyes Peninsula, Marin County, California: California Div. Mines and Geology Bul1. 202, p. 39-40

4. Clayey siltstone or claystone interbedded with coarse granitic gravel

5. Light-blue-gray, brownish-gray

6. $>200 \mathrm{~m}$, base not exposed

7. Thin-bedded, laminated, abundant organic material, freshwater diatoms; confined to central part of San Andreas fault zone

9. Inferred to unconformably overlie serpentine and related Franciscan rocks of San Andreas fault zone; underlies Quaternary sediments

10. Type section: Outcrop in Olema Creek between Boyd Stewart Ranch and Vedanta retreat, Marin County, Calif.

Olin Sandstone

1. Late Cambrian

2. New York (WC), Pennsylvania

3. Wagner, W. R., 1976, Growth faults in Cambrian and Lower Ordovician rocks of western Pennsylvania: Am. Assoc.

Petroleum Geologists Bull., v. 60 , no. 3, p. 414-427

4. Sandstone with interbeds of dolomite

6. $90 \mathrm{~m}$

7. Medium- to coarse-grained, subsurface; beach or barrier bar deposit

9. Overlies Warrior Limestone; underlies Gatesburg Formation

10. Type section: New York State Natural Gas Corp. Robert Olin 1 well, depth-interval 3,594-3,684 m, Woodhull Township, Steuben County, N.Y. 


\section{Donatut Granite Complex}

1. Late Cretaceous

2. Alaska (NC)

3. Hudson, Travis, 1979, Igneous and metamorphic rocks of the Serpentine Hot Springs area, Seward Peninsula, Alaska: U.S. Geol. Survey Prof. Paper 1079, p. 12-24

4. Biotite granite

5. Gray

7. Stock, peripheral dikes, tin mineralization

9. Exposed over area of $70 \mathrm{~km}^{2}$ and to deeper levels than any other tin-granites in belt. Intrudes unnamed Precambrian(?) and Paleozoic metamorphic rocks with sharp, discordant contact

10. Type locality: Serpentine Hot Springs area in headwater region of Serpentine River, Bendeleben D-6 and D-5 quadrangles, NC Seward Peninsula, Alaska. Named for Eskimo word for area.

Orange Mountain Basalt (Newark Supergroup)

1. Early Jurassic

2. New Jersey (NE), New York

3. Olsen, P. E., 1980, The latest Triassic and Early Jurassic formations of the Newark Basin (eastern North America, Newark Supergroup)--stratigraphy, structure, and correlation: New Jersey Acad. Sci. Bull., v. 25, no. 2, p. 32-34

4. Tholeiitic basalt flows and interbedded volcaniclastic units

6. $>50 \mathrm{~m}$, range $>50-200 \mathrm{~m}$

7. Massive, columnar, vesicular basalt

9. Overlies Passaic Formation; underlies Feltville Formation. Unit was formerly "first" Watchung Basalt of Darton (1890)

10. Type section: Exposures along U.S. Interstate Highway I-280 at its cut through Orange Mountain, East Orange, Essex County, N.J.

Osborne Wash Formation

1. Miocene to Pliocene(?)

2. Arizona (WC), California

3. Davis, G. A., and others, 1980, Mylonitization and detachment faulting in the Whipple-Buckskin-Rawhide Mountains terrane, southeastern California and western Arizona: Geol. Soc. America Mem. 153, p. 119, 122

4. Basal fanglomerates, basalt flows interbedded with agglomerate, tuff, and alluvial-fan deposits; intrusive dikes and plugs

6. $>400 \mathrm{~m}$

7. Basal fanglomerates and air-fall tuffs have filled old valleys with relief of at least $300 \mathrm{~m}$; unit deposited after detachment faulting

9. Unconformably overlies Gene Canyon and Copper Basin Formations and older crystalline rocks

10. Type section: Not stated. Widespread exposures in W Buckskin Mountains, Yuma County, Ariz., and in SE Whipple Mountains, San Bernardino County, Calif. Probably named for exposures in hills near Osborne Wash, where Arizona Highway 95 bridges the wash NE of Parker, Yuma County. 
2. Oklahoma (C)

3. Powell, B. N., Gilbert, M. C., and Fischer, J. F., 1980, Lithostratigraphic classification of basement rocks of the Wichita province, Oklahoma: Summary: Geol. Soc. America Bull., pt. 1, v. 91, no. 9, p. 510-513

4. Diorite, quartz-diorite

5. Dark-greenish-gray

7. Aphanitic, dikes, sills, irregular intrusions

9. Intrudes Glen Mountains Layered Complex and Roosevelt Gabbros (Raggedy Mountain Gabbro Group)

10. Type area: Outcrops near Otter Creek, sec. 15, T. 4 N., R. 17 W., Glen Mountains, Kiowa County, Okla.

Pacific Ridge Complex

1. Early Cretaceous or older

2. California (NW)

3. Suppe, John, and Foland, K. A., 1978, The Goat Mountain Schists and Pacific Ridge Complex--a redeformed but stillintact late Mesozoic Franciscan schuppen complex, in Howell, D. G., and McDougall, K. A., eds., Mesozolc paleogeography of the western United States--Pacific Coast Paleogeography Symposium 2 [Sacramento, Calif., 1978]: Los Angeles, Soc. Econ. Paleontologists and Mineralogists, Pacific Sec., p. 431-451

4. Interbedded metacherts, metagraywackes, metamudstones, and metavolcanic rocks

9. Structurally interlayered with Goat Mountain Schists in Franciscan terrane

10. Type area: 400-1,000 $\mathrm{m}$ along ridge extending $\mathrm{NW}$ from Goat Mountain summit, lat $39^{\circ} 0^{\prime} \mathrm{N}$. , long $122^{\circ} 45^{\circ} \mathrm{W}$. , Stonyford quadrangle, Lake County, Calif.

Page Sandstone (San Rafael Group)

1. Middle Jurassic (Bajocian and Bathonian)

2. Arizona (NC), Utah

3. Peterson, Fred, and Pipiringos, G. N., 1979, Stratigraphic relations of the Navajo Sandstone to Middle Jurassic formations in parts of southern Utah and northern Arizona: U.S. Geol. Survey Prof. Paper 1035-B, p. B20-B30

4. Sandstone containing angular chert pebbles at base

5. Red-orange, red-brown, light-gray

6. $\quad 55.8 \mathrm{~m}$, range $<1-88.7 \mathrm{~m}$

7. Fine-grained, well-sorted, crossbedded, cliff-forming

8. Harris Wash Tongue at base, Thousand Pockets Tongue

9. Unconformably overlies Navajo Sandstone (Glen Canyon Group); intertongues with Judd Hollow Tongue (Carmel Formation of San Rafael Group), which splits into Harris Wash and Thousand Pockets Tongues; underlies informal upper member of Carmel Formation

10. Type section: NW side of Manson Mesa on which town of Page is situated, SW1/4NW1/4 sec. 19 , T. $41 \mathrm{~N} ., \mathrm{R} .9 \mathrm{E} .$, Coconino County, Ariz.

\section{Pahrump Hills Shale Member (Carrara Formation)}

1. Middle Cambrian

2. Nevada (SC), California

3. Palmer, A. R., and Halley, R. B., 1979, Physical stratigraphy and trilobite biostratigraphy of the Carrara Formation 
(Lower and Middle Cambrian), southern Great Basin: U.S. Geol. Survey Prof. Paper 1047, p. 18-20

4. Siltstone, mudstone, shale, minor limestone and sandstone

5. Tan, red, green

6. Range $<1-94 \mathrm{~m}$

7. Thin-bedded, fossilfferous, terrigenous clastic deposits

9. Overlies with sharp contact Red Pass Limestone Member; conformably and gradationally underlies Jangle Limestone Member

10. Type locality: Exposures in Pahrump Hills, NW of Pahrump, Nye County, Nev.

Pamlico Formation

1. Triassic

2. Nevada (WC)

3. 0ldow, J. S., 1978, Triassic Pamlico Formation--an allochthonous sequence of volcanogenic-carbonate rocks in westcentral Nevada, in Howell, D. G., and McDougall, K. A., eds., Mesozoic paleogeography of the western United States-Pacific Coast Paleogeography Symposium 2 [Sacramento, Calif., 1978]: Los Angeles, Soc. Econ. Paleontologists and Mineralogists, Pacific Sec., p. 223-235

4. Limestone with interbedded volcanic and volcanogenic sedimentary rocks

6. $>1,500 \mathrm{~m}$

7. Limestone, medium- to coarse-grained, uniformly bedded; superimposed fold sets, high-angle faults

8. Informal lower, middle, and upper members comprising 21 mappable lithologic units

9. Base not observed; conformably underlies undifferentiated Sunrise and Gabbs Formations; in E Garfield Hills, thrust nappes of Pamlico and Dunlap Formations structurally intercalated

10. Type locality: Pamlico mining district, W Garfield Hills, Mineral County, Nev.

Panther Camp Formation (Naples Bay Group)

1. Early Cretaceous (Comanchean)

2. Florida (SE)

3. Winston, G. D., 1976, Six proposed formations in the undefined portion of the Lower Cretaceous section in south Florida: Gulf Coast Assoc. Geol. Socs. Trans., v. 26, p. 71

4. Limestone with thick anhydrite beds

6. $95 \mathrm{~m}$

7. Porous pelletal limestone at base, regionally persistent anhydrite bed at top

9. Overlies Gordon Pass Formation (Big Cypress Group); underlies Rookery Bay Formation (Naples Bay Group)

10. Type section: Humble No. 1 Collier Corp. well, depthinterval $3,002 \mathrm{~m}$, sec. 27, T. $50 \mathrm{~S} ., \mathrm{R} .26 \mathrm{E} .$, Collier County, Fla. Named for Panther Camp, $12.8 \mathrm{~km} \mathrm{~N}$ of type well.

Parkers Ferry Member (Cooper Formation)

1. Eocene, late

2. South Carolina (SC)

3. Ward, L. W., and others, 1979, Stratigraphic revision of Eocene, Oligocene, and lower Miocene formations of South 
Carolina: South Carolina Geol. Survey Geol. Notes, v. 23, no. 1, p. 23-24

4. Glauconitic, clayey limestone

5. Grayish-yellow-green, yellowish-gray, or pale-olive

6. $2.5 \mathrm{~m}$, range $2.5-40 \mathrm{~m}$

7. Fine-grained, fossiliferous; known only in subsurface

9. Unconformably overlies Harleyville Member; unconformably underlies Ashley Member

10. Type section: Clubhouse Crossroads Corehole 1, depthinterval 54.5-57 m, in Drayton Swamp, $3.5 \mathrm{~km}$ SW of Clubhouse Crossroads, Cottageville 15' quadrangle, Dorchester County, S.C. Type area: Drill holes SW to NE along $E$ side of Edisto River between Parkers Ferry and Ponpon on U.S. Highway 17, Charleston County, and Sullivans Ferry on U.S. Highway 17A, Dorchester County, S.C.

Parkman Hill Formation

1. Middle and Late Silurian (Wenlockian to Ludlovian)

2. Maine (WC)

3. Pankiwskyj, K. A., and others, 1976, Stratigraphic relationships on the southeast limb of the Merrimack synclinorium in central and west-central Maine: Geol. Soc. America Mem. 146 , p. $269,274-275$

4. Sulfidic carbonaceous metapelite, quartz-rich granule metaconglomerate and metasandstone, and nonsulfidic metasandstone

5. Weathers rusty

6. 200-300 $\mathrm{m}$, range $200-700 \mathrm{~m}$

7. Fossiliferous (graptolites)

9. Overlies and interfingers with Sangerville Formation; underlies Fall Brook Formation

10. Type locality: $S$ and SE slopes of Parkman Hill, NE Anson quadrangle, Somerset County, Maine.

Passaic Formation (Newark Supergroup)

1. Late Triassic and Early Jurassic

2. New Jersey (NE), New York, Pennsylvania

3. Olsen, P. E., 1980, The latest Triassic and Early Jurassic formations of the Newark Basin (eastern North America, Newark Supergroup)--stratigraphy, structure, and correlation: New Jersey Acad. Sci. Bull., v. 25, no. 2, p. 29-32

4. Siltstone, sandstone, conglomerate, and periodically spaced bundles of detrital cyclic non-red units

5. Red

6. $>6,000 \mathrm{~m} \max$

7. Cut by diabase intrusions and dikes

8. Perkasie Member

9. Conformably overlies Lockatong Formation; underlies Orange Mountain Basalt. Unit was formerly lower part of Brunswick Formation of Kümmel (1897)

10. Type section: Intermittent exposures along U.S. Highway I-80 near Passaic, Passaic County, N.J.

Pastillo Member (Lago Garzas Formation)

1. Late Cretaceous (Campanian(?) and Maestrichtian)

2. Puerto Rico (SC)

3. Krushensky, R. D., and Monroe, W. H., 1978, Geology of the Pefuelas and Punta Cuchara quadrangles, Puerto Rico: U.S. 
Geol. Survey Misc. Inv. Ser., Map I-1042

4. Volcaniclastic andesite breccia interbedded with lava flows and minor fine-grained marine sedimentary rocks

5. Dark-red, purple, green

6. $>1,000 \mathrm{~m}$

7. Thick-bedded to massive, deeply saprolitized locally

9. Conformably overlies and interbedded with Yauco Formation; interbedded with and underlies Santas Pascuas Member (Lago Garzas Formation)

10. Type area: Near headwaters of Río Pastillo, near Marueno, P.R.

Paxson Mountain Basalt (Amphitheater Group)

1. Triassic

2. Alaska (EC)

3. Stout, J. H., 1976, Geology of the Eureka Creek area, eastcentral Alaska Range: Alaska Div. Geol. and Geophys.

Surveys Geol. Rept. 46, p. 10-12

4. Basalt, amygdaloid basalt

5. Olive-gray to dark-green, maroon

6. Range $1,500-3,000 \mathrm{~m}$

7. Oldest unit in E-W Amphitheater syncline

9. Overlies Mankomen Group; underlies Tangle Lakes Formation (Amphitheater Group); intruded by Fish Lake Complex

10. Type locality: Paxson Mountain, Eureka Creek area, Mount Hayes A-4 quadrangle, EC Alaska Range, Alaska.

Perry Hall Gneiss

1. Cambrian-Ordovician(?)

2. Maryland (NC)

3. Crowley, W. P., 1976, The geology of the crystalline rocks near Baltimore and its bearing on the evolution of the eastern Maryland Piedmont: Maryland Geol. Survey Rept. Inv. 27, p. $17-18,30$

4. Biotite-quartz-plagioclase gneiss interlayered with hornblende-quartz-plagioclase gneiss

9. Overlies Bradshaw Layered Amphibolite and Raspeburg Amphibolite (Baltimore Mafic Complex) in NE-SW syncline

10. Type locality: Outcrops along Bel Air Road $N$ of Perry Hall, along NE-flowing tributary of Gunpowder Falls, and in abandoned quarry $450 \mathrm{~m} \mathrm{NE}$ of Gunpowder Falls, White Marsh quadrangle, Baltimore County, Md.

Persimmon Creek Gneiss (Coweeta Group)

1. Precambrian, late(?) [Late Proterozoic(?)]

2. Georgia (NC), North Carolina

3. Hatcher, R. D., Jr., 1979, The Coweeta Group and Coweeta syncline--major features of the North Carolina-Georgia Blue Ridge: Southeastern Geology, v. 21, no. 1, p. 21

4. Orthoclase-quartz-biotite gneiss, massive (lower member) or interlayered with metasandstone and biotite-muscovite-quartz schist

6. Range 1,300-2,000 m

7. Massive to interlayered, coarse, even-grained texture, forms exfoliated cliffs

8. Informal lower and upper members

9. Overlies Tallulah Falls Formation; underlies Coleman River Formation (Coweeta Group) 
10. Type area: Exposures along Persimmon Creek, Dillard quadrangle, NW Rabun County, Ga.

\section{Petrified Spring Tuff (Benton Spring Group)}

1. Oligocene

2. Nevada (WC)

3. Ekren, E. B., and others, 1980, Stratigraphy, preliminary petrology, and some structural features of Tertiary volcanics rocks in the Gabbs Valley and Gillis Ranges, Mineral County, Nevada: U.S. Geol. Survey Bul1. 1464, p. $28-29$

4. Rhyodacite and quartz latite tuff

6. $75 \mathrm{~m}$, range $<1-75 \mathrm{~m}$

7. Multiple-flow simple cooling unit

9. Overlies Singatse Tuff (Benton Spring Group) or unnamed ashflow cooling units; underlies Blue Sphinx Tuff

10. Type locality: Exposure $4 \mathrm{~km} \mathrm{~S}$ of Petrified Spring, NW1/4 sec. 31, T. 9 N., R. 35 E., S Gabbs Valley Range, Mineral County, Nev.

Phantom Lake Suite

1. Early Proterozoic

2. Wyoming (SE)

3. Karlstrom, K. E., and Houston, R. S., 1979, Stratigraphy and uranium potential of Early Proterozoic metasedimentary rocks in the Medicine Bow Mountains, Wyoming: Wyoming Geol. Survey Rept. Inv. 13, p. 9-11

4. Metavolcanic and metasedimentary rocks including quartzite and radioactive conglomerate

6. $3,000 \mathrm{~m}$

7. Tabular cross-bedding; depositional environments include subaerial, fluvial, and shallow marine

8. Lower volcanogenic sequence; upper fluvial and shallow marine sequence including, at top, informal Arrastre volcanics

9. Unconformably overlies Archean granitic rocks; unconformably underlies Magnolia Formation (Deep Lake Group)

10. Type area: S of Phantom Lake, T. 16 N., R. 79 W.; along North Fork of Rock Creek, T. $17 \mathrm{~N} .$, R. 79 W.; and NW1/4 sec. 23, T. 16 N., R. 81 W., Medicine Bow Mountains, Carbon County, Wyo.

\section{Piatt Till Member (Wedron Formation)}

1. Pleistocene

2. Illinois (EC)

3. Wickham, J. R., 1979, Glacial geology of north-central and western Champaign County, Illinois: Illinois Geol. Survey Circ. 506, p. 6-7

4. Loam till

5. Gray

6. $2.7 \mathrm{~m}$

9. Overlies Fairgrange Till Member; underlies Batestown Till Member

10. Type section: Mahomet I-74 Bridge Section, E bank of Sangamon River, $N$ of U.S. Highway I-74, NE1/4SE1/4NE1/4 sec. 15, T. 20 N., R. 7 E., Champaign County, Ill. Named for Piatt County. 


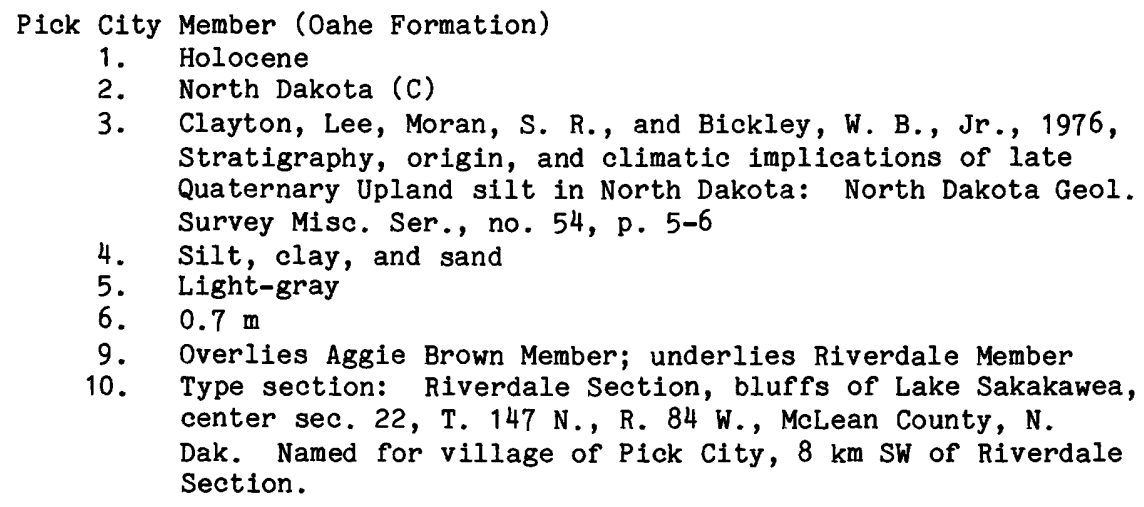

Pierz Granite

1. Precambrian, middle

2. Minnesota (C)

3. Morey, G. B., 1978, Lower and middle Precambrian stratigraphic nomenclature for east-central Minnesota: Minnesota Geol. Survey Rept. Inv. 21, p. 38

4. Granite

5. Light-gray

7. Fine- to medium-grained, equigranular, elliptical pluton $9 \mathrm{~km}$ long and $3 \mathrm{~km}$ wide

9. Intrudes Hillman Migmatite

10. Type locality: Abandoned quarry, SE1/4 sec. 13, T. 40 N., R. 31 W., Morrison County, Minn. Named for Pierz Lake, $3 \mathrm{~km}$ W of city of Pierz.

Piney Run Formation (Wissahickon Group)

1. Cambrian-Ordovician(?)

2. Maryland (NC)

3. Crowley, W. P., 1976, The geology of the crystalline rocks near Baltimore and its bearing on the evolution of the eastern Maryland Piedmont: Maryland Geol. Survey Rept. Inv. 27, p. 11,25

4. Plagioclase-chlorite-muscovite-quartz schist interlayered with biotite quartzite

6. Range $<1-2,100 \mathrm{~m}$

7. Fine-grained

9. Overlies Loch Raven Schist; underlies Sykesville Formation

10. Type locality: Outcrops along $1.7 \mathrm{~km}$ stretch of Piney Run and tributaries near Dover Church, WC Baltimore County, Md.

\section{Pinyon Creek Conglomerate}

1. Miocene, early

2. Utah (C)

3. Morris, H. T., and Lovering, T. S., 1979, General geology and mines of the East Tintic mining district, Utah and Juab Counties, Utah: U.S. Geol. Survey Prof. Paper 1024,

4. Conglomerate

5. Grayish-tan, reddish, purplish-brown

6. Range $5->305 \mathrm{~m}$

7. Lenses and beds, great range in size of rock fragments, alluvial fan deposits 
9. Disconformably overlies Pinyon Queen Latite (Laguna Springs Volcanic Group), Latite Ridge Latite (Tintic Mountain Group), or Packard Quartz Latite; disconformably underlies Silver Shield Quartz Latite

10. Type locality: Exposures in lower Pinyon Creek Canyon, N1/2 sec. 35, T. 9 S., R. 2 W., NE.East Tintic.mining district, Utah County, Utah.

\section{Pinyon Queen Latite (Laguna Springs Volcanic Group)}

1. Oligocene, middle

2. Utah (C)

3. Morris, H. T., and Lovering, T. S., 1979, General geology and mines of the East Tintic mining district, Utah and Juab Counties, Utah: U.S. Geol. Survey Prof. Paper 1024, p. 48-52

4. Latite flows, tuff, breccia, agglomerate

5. Flow: dark-reddish-brown

6. Tuff: range $0.15-122 \mathrm{~m}$; flow: $213 \mathrm{~m}$

7. Tuff: fine-grained to boulder agglomerate; flow: mediumto coarse-grained, massive, porphyritic

8. Informal lower tuff member and upper flow member

9. Unconformably overlies North Standard Latite (Laguna Springs Volcanic Group), Big Canyon or Latite Ridge Latites (Tintic Mountain Volcanic Group), or Packard Quartz Latite; underlies Tintic Delmar Latite (Laguna Springs Volcanic Group) or disconformably underlies Pinyon Creek Conglomerate

10. Type locality: Exposures E of Pinyon Queen shaft, secs. 34 and 35, T. 9 S., R. 2 W., East Tintic mining district, Utah County, Utah.

\section{Pitahaya Formation}

1. Early Cretaceous

2. Puerto Rico (EC)

3. M'Gonigle, J. W., 1977, The Río Abajo, Pitahaya, and Daguao Formations in eastern Puerto Rico: U.S. Geol. Survey Bull. 1435-B, p. B6-B7

4. Lava, autoclastic breccia, tuff and tuff breccia; volcanic sandstone

5. Dark-greenish-gray to olive or brownish-black lava, mediumto brownish-gray tuff and sandstone

6. $2,000 \mathrm{~m}$

9. In fault contact with Río Abajo Formation, but may unconformably overlie it $\mathrm{W}$ of study area; in intrusive contact with Tertiary(?) plutonic rocks of San Lorenzo batholith; unconformably underlies Quaternary deposits

10. Type area: Exposures along Route $926 \mathrm{~W}$ from Pitahaya and $\mathrm{N}$ along Route 937 (extended) along side of Cerro Colloras towards town of Melillas, from 38,900 N. and 216,300 E. to $40,700 \mathrm{~N}$. and $215,900 \mathrm{E}$., around town of Pitahaya, Municipio de Humacao, Humacao quadrangle, P.R.

\section{Pluma Member (Sespe Formation)}

1. Miocene, early

2. California (SC)

3. Yerkes, R. F., and Campbell, R. H., 1979, Stratigraphic nomenclature of the central Santa Monica Mountains, Los Angeles County, California: U.S. Geol. Survey Bull. 1457-E, p. E10-E11 
4. Sandstone and sandstone-mudstone sequence

5. Gray, grayish-red, olive-gray

6. $342 \mathrm{~m}$

9. Conformably overlies undivided Sespe Formation; intertongues with undivided Vaqueros Formation; conformably underlies Saddle Peak Member (Topanga Canyon Formation)

10. Type locality: Exposures in Piuma Road and at head of Carbon Canyon, NE1/4 sec. 21, T. 1 S., R. 17 W., Santa Monica Mountains, EC Malibu Beach quadrangle, Los Angeles County, Calif.

\section{Placer River Silt}

\section{Holocene}

2. Alaska (C)

3. Ovenshine, A. T., Lawson, D. E., and Bartsch-Winkler, S. R., 1976, The Placer River Silt--an intertidal deposit caused by the 1964 Alaska Earthquake: U.S. Geol. Survey Jour. Research, v. 4, no. 2, p. 151-162

4. Micaceous silt of quartz and feldspar with intercalated silty clay or fine-grained sand

5. Olive-gray

6. $1.18 \mathrm{~m}$ average, $1.07 \mathrm{~m}$

7. Medium- and coarse-silt-size grains, thin-bedded to laminated

9. Overlies soil horizon rich in organic material; in 1973 Placer River Silt was still being deposited

10. Type section: Exposure in $\mathrm{N}$ bank of $\mathrm{N}$ fork of Portage Creek W of Seward Highway, Portage, Alaska. Named for occurrence on Placer River.

\section{Plantation Tongue (Rebecca Shoal Dolomite)}

1. Late Cretaceous

2. Florida (SE)

3. Winston, G. 0., 1978, Rebecca Shoal reef-complex (Upper Cretaceous and Paleocene) in south Florida: Am. Assoc. Petroleum Geologists Bull., v. 62, no. 1, p. 124-127

4. Anhedral dolomite

5. Brown, cream

6. $218 \mathrm{~m}$

7. Subsurface barrier-reef complex; fine crystalline texture

9. Overlies Card Sound Dolomite; interfingers with Pine Key Formation; underlies Tavernier Tongue (Rebecca Shoal Dolomite)

10. Type section: Coastal Petroleum 1 state well 363, depthinterval 1,527-1,745 m, sec. 32, T. $62 \mathrm{~S} .$, R. $38 \mathrm{E}$., Monroe County, Fla. Named for town of Plantation, $3.2 \mathrm{~km} \mathrm{~S}$ of well.

Pleasant Grove Schist (Wissahickon Group)

1. Cambrian-Ordovician(?)

2. Maryland (NC)

3. Crowley, W. P., 1976, The geology of the crystalline rocks near Baltimore and its bearing on the evolution of the eastern Maryland Piedmont: Maryland Geol. Survey Rept. Inv. 27, p. 12

4. Plagioclase-chlorite-muscovite-quartz schist, locally with magnetite

6. Range $<1-2,200 \mathrm{~m}$ 
7. Uniform, fine-grained

9. Overlies Piney Run Formation or Della Formation; underlies Prettyboy Schist

10. Type locality: Outcrops along McGill Run and SE-flowing tributary $W$ and $S$ of Pleasant Grove Church, WC Baltimore County, Md.

Poinsettia Tuff Menber (Hu-pw1 Rhyodacite)

1. Miocene

2. Nevada (WC)

3. Ekren, E. B., and others, 1980, Stratigraphy, preliminary petrology, and some structural features of Tertiary volcanic rocks in the Gabbs Valley and Gillis Ranges, Mineral County, Nevada: U.S. Geol. Survey Bull. 1464, p. 40-41

4. Rhyodacite and quartz latite welded tuff

5. Gray, reddish-gray, brown

6. Range $<1-500 \mathrm{~m}$

7. Porphyritic, multiple-flow simple cooling units

9. Overlies Nugent Tuff Member (Hu-pwi Rhyodacite) or lava of Poinsettia Spring area (informal member of Hu-pwi Rhyodacite); underlies lava of Mount Ferguson or tuff of Copper Mountain

10. Type locality: Exposures in T. $10 \mathrm{~N} .$, R. 33 E., $2 \mathrm{~km} \mathrm{SSE}$ of Poinsettia Spring, N Gabbs Valley Range, Mineral County, Nev.

Point Reyes Conglomerate

1. Paleocene

2. California (WC)

3. Galloway, A. J., 1977, Geology of the Point Reyes Peninsula, Marin County, California: California Div. Mines and Geology Bull. 202, p. 18-19

4. Coarse conglomerate of granitic rocks in matrix of granitic sand, interbedded with silty, micaceous sand

6. $>200 \mathrm{~m}$, range $>200-400 \mathrm{~m}$, top eroded

7. Forms craggy or stacklike outcrops with vertical jointing

9. Unconformably overlies granitic basement rocks; unconformably underlies Drakes Bay Formation

10. Type section: Outcrops at lighthouse on $W$ end of Point Reyes, Marin County, Calif.

Pollocksville Member (Belgrade Formation)

1. Miocene, early

2. North Carolina (EC)

3. Ward, L. W., Lawrence, D. R., and Blackwelder, B. W., 1978, Stratigraphic revision of the middle Eocene, Oligocene, and lower Miocene--Atlantic Coastal Plain of North Carolina: U.S. Geol. Survey Bull. 1457-F, p. F14-F15

4. Oyster-shell bed

5. Tan to orange

6. $4 \mathrm{~m}$

7. Leached, unconsolidated, sandy Crassostrea bed; nearshore equivalent of offshore Haywood Landing Member

9. Unconformably overlies and occupies channels in River Bend Formation; upper contact covered

10. Type locality: Exposures on $L$ bank of Trent River next to Seaboard Coastline Railroad trestle, Pollocksville, Jones County, N.C. 


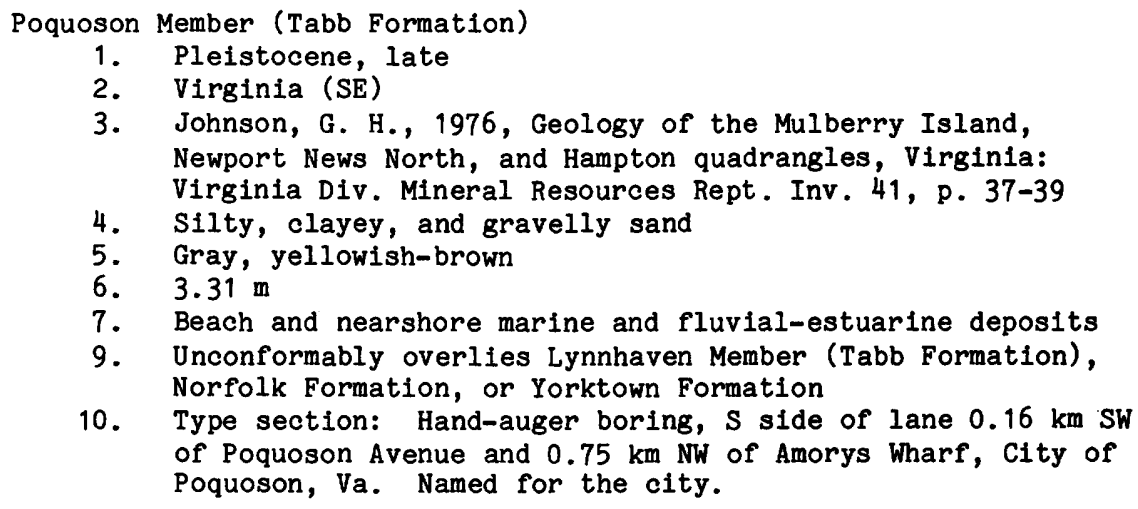

Po River Metamorphic Suite (Fredericksburg Complex)

1. Late Proterozoic and (or) Paleozoic, early

2. Virginia (EC)

3. Pavlides, Louis 1980 , Revised nomenclature and stratigraphic relationships of the Fredericksburg Complex and Quantico Formation of the Virginia Piedmont: U.S. Geol. Survey Prof. Paper 1146 , p. 4-7

4. Biotite gneiss, augen gneiss, schist, granitoid and pegmatoid bodies

5. Dark

7. Layered, foliated

9. Base not exposed; in contact with Ta River Metamorphic Suite along Spotsylvania lineament; Intruded by Falls Run Granite Gneiss

10. Composite type area: Along Po River between Spotsylvania lineament and U.S. Route 1 , and along $\mathrm{Ni}$ River between Spotsylvania lineament and U.S. Route 1, Spotsylvania quadrangle, Spotsylvania County, Va.

Portage Canyon Member (Laketown Dolostone)

1. Middle Silurian

2. Utah (NW), Nevada

3. Budge, D. R., and Sheehan, P. M., 1980, The Upper Ordovician through Middle Silurian of the eastern Great Basin--Pt. 1, Introduction--historical perspective and stratigraphic synthesis; Pt. 2, Lithologic descriptions: Milwaukee Public Mus. Contr. Blology and Geology, no. 28, p. 20 (pt. 1); no. 29 , p. 76-77 (pt. 2)

4. Dolomite

5. Brownish-gray

6. $61 \mathrm{~m}$

7. Finely crystalline, medium- to thick-bedded

9. Ovierlies Gettel Member or High Lake Member; underlies Jack Valley Member or Decathon Member

10. Type section: Near mouth of Portage Canyon, on Samaria Mountain, $3.2 \mathrm{~km} \mathrm{~W}$ of Portage, T. $14 \mathrm{~N} .$, R. $4 \mathrm{~W}$. , West Hills, Bear River Range, Box Elder County, Utah.

Potato Canyon Rhyolite

1. Oligocene

2. New Mexico (WC)

3. Deal, E. G., and Rhodes, R. C., 1976, Volcano-tectonic 
structures in the San Mateo Mountains, Socorro County, New Mexico: New Mexico Geol. Soc. Spec. Pub. 5, p. 54-55

4. Rhyolite ash-flow tuff with numerous phenocrysts

5. Reddish-brown

6. $1,700 \mathrm{~m}$

7. Massive, densely welded; erupted from Mount Withington cauldron

9. Overlies A-L Rhyolite; unconformably underlies Beartrap Canyon Formation

10. Type locality: Potato Canyon, N San Mateo Mountains, sec. 12, T. 5 S., R. 6 W., Socorro County, N. Mex.

Powers Ferry Formation (Sandy Springs Group)

1. Precambrian, late(?) and (or) Paleozoic, early(?)

2. Georgia (NW)

3. Higgins, M. W., and McConnell, K. I., 1978, The Sandy Springs Group and related rocks in the Georgia Piedmont-nomenclature and stratigraphy: U.S. Geol. Survey Bull. 1457-A, p. A101-A103 (Also published in: Georgia Geol. Survey Bull. 93, p. 51-52, 1978)

4. Biotite-oligoclase-microcline gneiss with intercalated muscovite-biotite schist and amphibolite

5. Gray

6. $>1,000 \mathrm{~m}$

7. Isoclinally folded, present only in cores of antiforms

8. Mableton Amphibolite Member

9. Apparently oldest formation in Sandy Springs Group, base not exposed; underlies in sharp contact (unconformably?) Chattahoochee Palisades Quartzite

10. Type section: Exposures along Anneewakee Creek and along road leading to Camp Anneewakee, Campbellton quadrangle. Type area: Exposures in new cuts in Powers Ferry Landing shopping center and office park, Sandy Springs quadrangle, Fulton County, Ga.

\section{Prater Creek Ash-flow Tuff}

1. Miocene, late

2. Oregon (EC)

3. Walker, G. W., 1979, Revisions to the Cenozoic stratigraphy of Harney basin, southeastern Oregon: U.S. Geol. Survey Bull. 1475, p. 20-23

4. Tuff

5. Pale-grayish-red

6. $12 \mathrm{~m}$, range $12-30 \mathrm{~m}$

7. Devitrified, crystal-poor, with abundant grayish-pink $2-\mathrm{cm}$ or smaller lithophysae

9. Overlies unnamed tuffaceous sedimentary rocks which overlie Devine Canyon Ash-flow Tuff; underlies unnamed tuffaceous sedimentary rocks and basalt which underlie Rattlesnake Ashflow Tuff

10. Type section: Exposures on walls of Poison Creek, adjacent to U.S. Highway 395,11 to $12 \mathrm{~km} \mathrm{~N}$ of Burns, lat $43^{\circ} 41^{\prime} \mathrm{N}$., long $119^{\circ} \mathrm{W}$. , Harney County, Oreg. Named for exposures along Prater Creek, $17 \mathrm{~km} \mathrm{NE}$ of Burns.

Preakness Basalt (Newark Supergroup)

1. Early Jurassic

2. New Jersey (NE), New York 
3. Olsen, P. E., 1980, The latest Triassic and Early Jurassic formations of the Newark Basin (eastern North America, Newark Supergroup)--stratigraphy, structure, and correlation: New Jersey Acad. Sci. Bull., v. 25, no. 2, p. 34-36

4. Extrusive, thick tholeiltic basalt flows and interbedded volcaniclastic siltstone

6. $500 \mathrm{~m}$

7. Basalt is coarse-grained and jointed

9. Overlies Feltville Formation; underlies Towaco Formation. Unit was formerly "second" Watchung Basalt of Darton (1890)

10. Type section: Exposure along U.S. Highway I-280, $2.25 \mathrm{~km} \mathrm{~W}$ of Orange Mountain Basalt type section. Named for Preakness Mountain, local name of Second Watchung Mountain, near Franklin Lakes, Essex County, N.J.

Prentiss Creek Member (Bush Bay Dolostone)

1. Middle Silurian (Niagaran)

2. Michigan (EC)

3. Johnson, A. M., and others, 1979, The Maple Block knoll reef in the Bush Bay Dolostone (Silurian, Engadine Group), Northern Peninsula of Michigan: Michigan Univ. Mus. Paleontology Papers on Paleontology, no. 20, p. 14

4. Dolomite, chert

5. Gray to brown

6. $8 \mathrm{~m}$

7. Thin- to medium-bedded, fine- to medium-crystalline, organic reef, fossiliferous

9. Overlies Rapson Creek Dolostone; underlies Swede Road Member (Bush Bay Dolostone)

10. Type locality: Cedarville quarry of U.S. Steel Corp., Mackinac County, Mich. Named for Prentiss Creek, which flows into Prentiss Bay about $9 \mathrm{~km} \mathrm{E}$ of Cedarville.

Prettyboy Schist (Wissahickon Group)

1. Cambrian-Ordovician(?)

2. Maryland (NC)

3. Crowley, W. P., 1976, The geology of the crystalline rocks near Baltimore and its bearing on the evolution of the eastern Maryland Piedmont: Maryland Geol. Survey Rept. Inv. 27, p. 12

4. Plagioclase-chlorite-muscovite-quartz schist, commonly with albite porphyroblasts and magnetite

7. Uniform, fine-grained

9. Overlies Pleasant Grove Schist (Wissahickon Group); upper contact not stated

10. Type locality: Outcrops near dam at Prettyboy Reservoir, Hereford quadrangle, Baltimore County, Md.

Principio Creek Member (James Run Formation)

1. Paleozoic, early

2. Maryland (NE)

3. Higgins, M. W., 1977, Six new members of the James Run Formation, Cecil County, northeastern Maryland: U.S. Geol. Survey Bull. 1435-A, p. A126-A127

4. Biotite-feldspar schist, possibly meta-andesite, with relict plagioclase phenocrysts, and epidosite inclusions, and metavolcanic rocks

5. Dark-gray, dark-green 
6. $610 \mathrm{~m}$

7. Medium-grained

9. Underlies unnamed felsite member of James Run Formation; probably partly equivalent to parts of Happy Valley Branch Member and parts of Port Deposit Gneiss

10. Type section: Exposures along Principio Creek NW of Port Deposit Road, Cecil County, Md.

Principlo Furnace Nember (James Run Formation)

1. Paleozoic, early

2. Maryland (NE)

3. Higgins, M. W., 1977, Six new members of the James Run Formation, Cecil County, northeastern Maryland: U.S. Geol. Survey Bull. 1435-A, p. A125-A126

4. Intermediate to felsic metavolcanic rocks with relict phenocrysts of plagioclase, quartz, and amphibole; and diamictites

5. Dark- to light-gray to white

6. $760 \mathrm{~m}$

7. Interbedded, multiply folded

9. Gradationaliy underlies Frenchtown Member; probably partly equivalent to Little Northeast Creek Member

10. Type section: Exposures in Principio Creek from just $S$ of Maryland Highway 7 to Just $N$ of U.S. Highway 40 , Cecil County, Md. Named for Principio Furnace on Principio Creek, Cecil County.

\section{Prow Pass Member (Crater Flat Tuff)}

1. Miocene

2. Nevada (SC)

3. Byers, F. M., Jr., and others, 1976, Volcanic sultes and related cauldrons of Timber Mountain-Oasis Valley caldera complex, southern Nevada: U.S. Geol. Survey Prof. Paper 919, p. 14-15

4. Ash-flow tuff

5. Light-gray, grayish-pink, or orange-pink where devitrified; light-brown where glassy

6. $15.2 \mathrm{~m}$, range $15-50 \mathrm{~m}$

7. Glassy, devitrified, welded, single cooling unit phenocryst

9. Overlies Bullfrog Member (Crater Flat Tuff) or intervening unnamed breccia, bedded tuff, or ash-flow tuff; underlies all constructional lavas of Wahmonie-Salyer volcanic center and rhyolite lavas of Calico Hills

10. Type locality: Prow Pass, at $\mathrm{N}$ end of Yucca Mountain, Nye County, Nev.

\section{Pumpkinvine Creek Formation}

1. [Pennsylvanian or older, middle Paleozoic(?)]

2. Georgia (NW)

3. McConnell, K. I., 1980, Origin and correlation of the Pumpkinvine Creek Formation--a new unit in the Piedmont of northern Georgia: Georgia Geol. Survey Inf. Circ. 52, p. 1-19

4. Amphibolite, thin interlayers of gneiss and phyllite

5. Gray

6. $<38 \mathrm{~m}$

7. Fine-grained, interlayered, folded, easily traceable

9. Structurally overlies informal Galts Ferry gneiss; 
structurally underlies Canton Schist; sequence occupies overturned antiform

10. Type locality: Exposures just SE of Pumpkinvine Creek along U.S. Highways I-75 and 41, SE Bartow County, Ga.

\title{
Puncheon Camp Sandstone Member (Norton Formation)
}

\author{
1. Middle Pennsylvanian \\ 2. Virginia (SW) \\ 3. Meissner, C. R., Jr., 1978, Geologic map of Duty quadrangle, \\ Dickenson, Russell, and Buchanan Counties, Virginia: U.S. \\ 4. Sandstone \\ 5. Gray \\ 6. Range $12-18 \mathrm{~m}$ \\ 7. Fine- to coarse-grained, massive, forms ledges \\ 9. Overlies Puncheon Camp No. 1 coal bed; underlies Puncheon \\ Camp No. 2 coal bed; lies above McClure Sandstone Member \\ (Norton Formation) \\ 10. Type section: Along Long Ridge near town of Duty, Duty \\ quadrangle, on border of Buchanan and Dickenson Counties, \\ Va.
}

\section{Puritan Quartz Monzonite}

1. Precambrian, early [Late Archean]

2. Michigan (NW)

3. Schmidt, R. G., 1976, Geology of the Precambrian W (lower Precambrian) rocks in western Gogebic County, Michigan:

4. Quartz monzonite

5. Pale-pinkish-gray

7. Medium- to coarse-grained, coarsely porphyritic, intrusive igneous body

9. Grades southward into Van Buskirk Gneiss within PuritanVan Buskirk pluton; intrudes Ramsay Formation and Whiskers Creek Gneiss; intruded by Sunset Creek Intrusive Complex; to $\mathrm{N}$, underlies younger Precambrian strata

10. Type locality: Exposures in SW1/4 sec. 17 and NW1/4 sec. 20, T. 47 N., R. $46 \mathrm{~W}$., close to site of old Puritan Mine, $S$ of community of Puritan, Gogebic County, Mich.

\section{Pyramid Shale Member (Carrara Formation)}

1. Early and Middle Cambrian

2. California (EC), Nevada

3. Palmer, A. R., and Halley, R. B., 1979, Physical stratigraphy and trilobite biostratigraphy of the Carrara Formation (Lower and Middle Cambrian), southern Great Basin: U.S. Geol. Survey Prof. Paper 1047, p. 14-17

4. Shale interbedded with siltstone, minor quartzite and limestone

5. Green, brown, maroon

6. Range $<1-172 \mathrm{~m}$

7. Fissile, slump folds, fossiliferous

9. Overlies with sharp contact Gold Ace Limestone Member, or is inseparable from Echo Shale Member where Gold Ace is absent; conformably underlies Red Pass Limestone Member

10. Type locality: Exposures at $W$ base of Pyramid Peak, Funeral Mountains, Inyo County, Calif. 
Pysht Fornation (Twin River Group)

1. Oligocene, late, and Miocene, early (Zemorrian and Saucesian)

2. Washington (NW)

3. Snavely, P. D., Jr., Niem, A. R., and Pearl, J. E., 1978, Twin River Group (upper Eocene to lower Miocene)--defined to include the Hoko River, Makah, and Pysht Formations, Clallam County, Washington: U.S. Geol. Survey Bull. 1457-A, p. A118-A120

4. Mudstone, sandy siltstone, with conglomerate and sandstone interbeds

5. Gray to olive-gray

6. Range $1,100-1,400 \mathrm{~m}$

7. Massive mudstone and siltstone; conglomerate and sandstone channels and lenses; calcareous concretions; fossiliferous

9. Gradationally, or locally unconformably, overlies Makah Formation (Twin River Group); gradationally underlies Clallam Formation

10. Type locality: Shore-cliff exposures along $18 \mathrm{~km}$ of Strait of Juan de Fuca from Pillar Point State Park, center sec. 10, T. $31 \mathrm{~N} .$, R. $11 \mathrm{~W} ., \mathrm{E}$ to point $3.5 \mathrm{~km} \mathrm{~W}$ of Low Point, SW1/4 sec. 19, T. 31 N., R. 9 W., Clallam County, Wash. Named for Pysht River, which flows into Strait of Juan de Fuca at Pillar Point.

Quartzite Peak Quartzite (Libby Creek Group)

1. Early Proterozoic

2. Wyoming (SC)

3. Divis, A. F., 1976, Geology and geochemistry of Sierra Madre Range, Wyoming: Colorado School Mines Quart., v. 71, no. 3, p. 27

4. Orthoquartzite

5. White

6. $>1,000 \mathrm{~m}$

7. Massive, unbedded, vitreous

8. Lithologically similar to Sugarloaf Quartzite in Medicine Bow Range; conformably overlies Copper Creek Conglomerate; conformably underlies Slaughterhouse Marble

10. Type area: Exposures at Quartzite Peak and along North Fork of Encampment River, Sierra Madre Range, Carbon County, Wyo.

\section{Quassaic Quartzite}

1. Middle Ordovician

2. New York (SE)

3. Fisher, D. W., 1977, Correlation of the Hadrynian, Cambrian and Ordovician Rocks in New York State: New York State Mus. Map and Chart Ser. 25, p. 60-61

4. Quartzite and quartzitic sandstone with interbedded conglomerate, subgraywacke, and shale

6. $122 \mathrm{~m}, 610 \mathrm{~m} \max$

7. Massive, molasse deposits derived from subaerially exposed allochthonous gravity slide units

9. Conformably but sharply overlies Snake Hill Shale; unconformably underlies Wilbur Limestone

10. Type locality: Along railroad, $1.6 \mathrm{~km} \mathrm{SW}$ of Esopus, Ulster County, N.Y. 
Ramera Canyon Tongue (Conejo Volcanics)

1. Miocene, middle

2. California (SC)

3. Yerkes, R. F., and Campbell, R. H., 1979, Stratigraphic nomenclature of the central Santa Monica Mountains, Los Angeles County, California: U.S. Geol. Survey Bull. 1457-E, p. E24

4. Basaltic and andesitic breccia, tuff-breccia, flows(?)

6. $518 \mathrm{~m}$

9. Lowest of three named tongues of Conejo Volcanics (Topanga Group), which are recognized only in upper plate of Malibu Bowl detachment fault. Overlies Topanga Canyon Formation (Topanga Group); underlies and interfingers with Escondido Canyon Shale and Dry Canyon Sandstone Members (Calabasas Formation)

10. Type area: Ramera Canyon, Santa Monica Mountains, EC Point Dume quadrangle, Los Angeles County, Callf.

\section{Ramsay Formation}

1. Precambrian, early [Late Archean]

2. Michigan (NW)

3. Schmidt, R. G., 1976, Geology of the Precambrian W (lower Precambrian) rocks in western Gogebic County, Michigan: U.S. Geol. Survey Bull. 1407, p. 6-8

4. Siliceous arkosic argillite, micaceous and arkosic metasiltstone, and metavolcanic tuff and breccia

6. $>300 \mathrm{~m}$

7. Thinly laminated, stratified, metamorphosed, schistose

9. Grades into Whiskers Creek Gneiss close to Puritan Quartz Monzonite, which intrudes them; to $\mathrm{N}$, unconformably underlies younger Precambrian strata

10. Type locality: Outcrops extending $S$ from edge of village of Ramsay along $W$ side of Black River, SW1/4 sec. 13, NW1/4 sec. 24 and within area $330 \mathrm{~m} \mathrm{~S}$ and $W$ of NE corner sec. 23, all in T. 47 N., R. 46 W., Gogebic County, Mich.

Randall Formation (Mille Lacs Group)

1. Precambrian, middle

2. Minnesota (C)

3. Morey, G. B., 1978, Lower and middle Precambrian stratigraphic nomenclature for east-central Minnesota: Minnesota Geol. Survey Rept. Inv. 21, p. 21-23

4. Metamorphosed basalt and diabase with lenses of cherty ironformation and quartzite

5. Greenish-black, black

9. Unconformably overlies and infolded with early Precambrian gneissic rocks, undivided; or overlies and underlies strata similar to Denham and Little Falls Formations, respectively, but assigned to Mille Lacs Group, undivided

10. Type locality: Exposures in and near village of Randall, sec. 7, T. 130 N., R. 30 W., Morrison County, Minn.

Rapson Creek Dolostone (Engadine Group)

1. Middle Silurian (Niagaran)

2. Michigan (EC)

3. Johnson, A. M., and others, 1979, The Maple Block knoll reef in the Bush Bay Dolostone (Silurian, Engadine Group), Northern Peninsula of Michigan: Michigan Univ. Mus. Paleon- 
tology Papers on Paleontology, no. 20, p. 14

4. Dolomite

5. Light-gray to buff-gray, weathers mottled white-yellow

6. $21 \mathrm{~m}$, range $21-27 \mathrm{~m}$

7. Massive, medium- to coarsely crystalline, organic reef, fossiliferous, banded

9. Conformably overlies Rockview Dolostone; underlies Prentiss Creek Member (Bush Bay Dolostone)

10. Type section: Cedarville quarry of U.S. Steel Corp., Mackinac County, Mich. Named for Rapson Creek, a stream NE of Cedarville.

Raspeburg Amphibolite (Baltimore Mafic Complex)

1. Cambrian(?)

2. Maryland (NC)

3. Crowley, W. P., 1976, The geology of the crystalline rocks near Baltimore and its bearing on the evolution of the eastern Maryland Piedmont: Maryland Geol. Survey Rept. Inv. 27, p. 16,28

4. Plagioclase-hornblende amphibolite

6. Range $<1-1,200 \mathrm{~m}$

7. Fine- to medium-grained

9. Underlies Perry Hill Gneiss in NE-SW syncline; to NE, passes into Bradshaw Layered Amphibolite (Baltimore Mafic Complex); in thrust-fault contact with Wissahickon Group

10. Type locality: Outcrops on Glenmount School property and abandoned quarry on W side of Bel Air Road, $400 \mathrm{~m} \mathrm{~S}$ of its intersection with Raspe Avenue, Raspeburg section of Baltimore City, Baltimore County, Md.

Rattlesnake Hammock Formation (Ocean Reef Group)

1. Early Cretaceous (Comanchean)

2. Florida (SE)

3. Winston, G. D., 1976, Six proposed formations in the undefined portion of the Lower Cretaceous section in south Florida: Gulf Coast Assoc. Geol. Socs. Trans., v. 26, p. 72

4. Anhydrite, limestone, dolomite

6. $225 \mathrm{~m}$

7. Thick, dense limestone at base; thick, regionally persistent anhydrite at top

9. Overlies Lake Trafford Formation (Ocean Reef Group); underlies Marco Junction Formation (Big Cypress Group)

10. Type section: Humble No. 1 Collier Corp. well, depthinterval 3,369-3,594 m, sec. 27, T. 50 S., R. 26 E., Collier County, Fla. Named for Rattlesnake Hammock, a natural feature $1.6 \mathrm{~km} \mathrm{~N}$ of type well.

Rebecca Shoal Dolomite

1. Late Cretaceous and Paleocene

2. Florida (SE)

3. Winston, G. 0., 1978, Rebecca Shoal reef-complex (Upper Cretaceous and Paleocene) in south Florida: Am. Assoc. Petroleum Geologists Bull., v. 62, no. 1, p. 121-127

4. Anhedral dolomite

5. Gray, tan, white

6. $606 \mathrm{~m}$

7. Subsurface, barrier-reef complex, fine-crystalline, numerous vugs, cavities, and caverns 
8. Plantation Tongue and Tavernier Tongue

9. Equivalent to and interfingers with Pine Key and Cedar Keys Formations

10. Type section: Electric log of Gulf-California 1 ocS Block 46 (permit 296), depth-interval 1,116-1,722 m, lat $24^{\circ} 26^{\prime}$ N., long $82^{\circ} 30^{\prime}$ W., Fla. Named for bathymetric feature, 11 nautical miles $N$ of type well, Straits of Florida.

Red Hills Tuff Member (Mount Belknap Volcanics)

1. Miocene

2. Utah (SC)

3. Steven, T. A., and others, 1979, Revised stratigraphy and radiometric ages of volcanic rocks and mineral deposits in the Marysvale area, west-central Utah: U.S. Geol. Survey BuIl. 1469, p. 26-27

4. Ash-flow tuff

5. Red, gray

6. $300 \mathrm{~m}$

7. Simple cooling unit of densely welded ash-flow tuff derived from Red Hills caldera

9. Overlies Joe Lott Tuff Member or intervening unnamed crystal-rich or upper red tuff members; underlies Gray Hills Rhyolite Member; units are part of outflow facies of Mount Belknap Volcanics

10. Type area: Red Hills, about $4.8 \mathrm{~km} \mathrm{~N} 10^{\circ} \mathrm{E}$ of center of Marysvale, Piute County, Utah.

Red Lick Member (Foreknobs Formation)

1. Late Devonian

2. West Virginia (C), Maryland, Virginia

3. McGhee, G. R., Jr., and Dennison, J. M., 1976, The Red Lick Member, a new subdivision of the Foreknobs Formation (Upper Devonian) in Virginia, West Virginia, and Maryland: Southeastern Geology, v. 18, no. 1, p. 49-57

4. Sandstone and siltstone with minor shale and conglomerate

5. Light-olive-gray

6. $166 \mathrm{~m}$, range $<1-213 \mathrm{~m}$

7. Marine lagoonal deposit

9. Conformably overlies Pound Sandstone Member (Foreknobs Formation); underlies Hampshire Formation

10. Type section: Exposures along road beside Briery Gap Run, extending from U.S. Highway 33 toward Spruce Knob, Pendleton County, W. Va. Named for Red Lick Run, lat $38^{\circ} 41^{\prime \prime} 1 "$ N., long $79^{\circ} 29^{\prime} 52^{\prime \prime}$ W., $5.8 \mathrm{~km}$ SW of Briery Gap Run section.

Red Mountain Subgroup (Chilliwack Group)

1. Early Pennsylvanian

2. Washington (NC), Canada (British Columbia)

3. Danner, W. R., 1977, Paleozoic rocks of northwest Washington and adjacent parts of British Columbia, in Stewart, J. H., and others, eds., Paleozoic paleogeography of the western United States--Pacific Coast Paleogeography Symposium 1 [Bakersfield, Calif., 1977]: Los Angeles, Soc. Econ. Paleontologists and Mineralogists, Pacific Sec., p. 489

4. Argillite, siltstone, limestone

6. Range $313-825 \mathrm{~m}$

7. Turbidites and graded bedding in lower argillite-siltstone unit; fossiliferous upper limestone unit 
9. Middle division of Chilliwack Group; overlies Sumas Mountain Subgroup; underlies Black Mountain Subgroup

10. Type area: Quarry exposures on Red Mountain and Black Mountain, Whatcom County, Wash.

Red Narrows Conglomerate

1. Late Cretaceous and Paleocene

2. Utah (C)

3. Young, G. E., 1976, Geology of Billies Mountain quadrangle, Utah County, Utah: Brigham Young Univ. Geology Studies, v. 23, pt. 1, p. 220-226

4. Conglomerate, sandstone, shale, limestone

5. Red to reddish-brown

6. $430 \mathrm{~m}$

7. Massive, bedded

8. Informal lower massive conglomerate unit; middle interbedded conglomerate-filled channels, sandstone, and shale unit; upper interbedded conglomerate, sandstone, shale, and limestone unit

9. Overlies Cretaceous conglomerate with angular unconformity; lies at surface or underlies and interfingers with Flagstaff Limestone

10. Type section: Exposures extending from summit of Teat Mountain, NW1/4SW1/4SW1/4 sec. 15, T. 9 S., R. 5 E., along ridge crest on E side of Rough Hollow down to Red Narrows Canyon and U.S. Highway 50-6, NE1/4SW1/4NW1/4 sec. 33, T. 9 S., R. 5 E., Utah County, Utah.

Red Pass Limestone Member (Carrara Formation)

1. Middle Cambrian

2. California (EC), Nevada

3. Palmer, A. R., and Halley, R. B., 1979, Physical stratigraphy and trilobite biostratigraphy of the Carrara Formation (Lower and Middle Cambrian), southern Great Basin: U.S.

Geol. Survey Prof. Paper 1047, p. 17-18

4. Limestone, lime mudstone, oolite

5. Light-gray, white

6. Range $<1-107 \mathrm{~m}$

7. Cliff-forming, burrowed, oncolitic, fossiliferous

9. Conformably overlies Pyramid Shale Member; underlies, with sharp contact, Pahrump Hills Shale Member

10. Type locality: Exposures on $W$ side of Titanothere Canyon below Thimble Peak, Grapevine Mountains, Inyo County, Calif. Named for Red Pass, $1 \mathrm{~km} \mathrm{E}$ of Titanothere Canyon.

Red Rock Ranch Formation

1. Oligocene

2. New Mexico (WC)

3. Deal, E. G., and Rhodes, R. C., 1976, Volcano-tectonic structures in the San Mateo Mountains, Socorro County, New Mexico: New Mexico Geol. Soc. Spec. Pub. 5, p. 52

4. Andesite flows with interbedded sedimentary rocks

6. $1,000 \mathrm{~m}$

7. Thin lacustrine interbeds contain plant fossils; source of eruption unknown, older than Nogal Canyon cauldron

9. Unconformably overlies Paleozoic rocks; unconformably underlies Rock Spring Formation 
10. Type locality: Red Rock Ranch, S San Mateo Mountains, sec. 13, T. 10 S., R. 6 W., Sierra County, N. Mex.

\section{Redrock Valley Tuff}

1. Miocene

2. Nevada (SC)

3. Byers, F. M., Jr., and others, 1976, Volcanic suites and related cauldrons of Timber Mountain-Oasis Valley caldera complex, southern Nevada: U.S. Geol. Survey Prof.

Paper 919, p. 7-10

4. Ash-flow tuff

5. Light-purplish-gray mottled with red

6. $125 \mathrm{~m}$, range $30-418 \mathrm{~m}$

7. Welded to nonwelded, has zonation of simple cooling unit

9. Overlies Paleozolc rocks or Miocene unnamed bedded tuff, which overlies Fraction Tuff; underlies, with local unconformity, unnamed bedded tuff, which underlies Bullfrog Member (Crater Flat Tuff)

10. Type locality: Exposure on W side of Yucca Flat at hill $5504,2.4 \mathrm{~km}$ E of head of Redrock Valley, Tippipah Spring quadrangle, Nye County, Nev.

\section{Reformatory Granite}

1. Precambrian, middle

2. Minnesota (C)

3. Morey, G. B., 1978, Lower and middle Precambrian stratigraphic nomenclature for east-central Minnesota: Minnesota Geol. Survey Rept. Inv. 21, p. 38-40

4. Granite containing inclusions of hornblende and biotite schist and dikes of granite porphyry and aplite

5. Light- to dark-gray

7. Massive, porphyritic; large, subsurface pluton

9. Intruded by Stearns Granitic Complex

10. Type locality: Abandoned quarries $\mathrm{N}$ of St. Cloud State Reformatory, SE1/4SW $1 / 4$ and SW1/4SE1/4 sec. 6, T. $35 \mathrm{~N}$. , R. 30 W., Sherburne County, Minn.

\section{Reinecker Ridge Volcanic Member (South Park Formation)}

1. Paleocene

2. Colorado (C)

3. Wyant, D. G., and Barker, Fred, 1976, Geologic map of the Milligan Lakes quadrangle, Park County, Colorado: U.S. Geol. Survey Geol. Quad. Map GQ-1343

4. Hornblende andesite porphyry flows and breccias, lenticular porphyry-cobble conglomerate beds, and tuffaceous sandstone

5. Brown, gray, green, or purple

6. Range 150-305 m

7. Forms steep-sided ridges; weathers to distinctive pellets in lower part

9. Overlies Laramie Formation; underlies unnamed conglomeratic member (South Park Formation)

10. Type locality: Reinecker Ridge (formerly Basin Ridge) along aqueduct road, sec. 20, T. 9 S., R. 76 W., Como quadrangle, Park County, Colo. 
3. Lee, K. Y., 1977, Triassic stratigraphy in the northern part of the Culpeper basin, Virginia and Maryland: U.S. Geol. Survey Bull. 1422-C, p. C3-C4

4. Gravel; contains lenses of siltstone, sandstone, and conglomerate

5. Pink to red-purple

6. $\quad 5.5 \mathrm{~m}$, range $5.5-22 \mathrm{~m}$

7. Loose to semicompact fluvial fan deposit, compact channelshaped lenses

9. Unconformably overlies pre-Triassic mica schist; underlies and intertongues with unnamed sandstone member of Manassas Sandstone (Newark Group)

10. Type section: Exposures $E$ of entrance junction of $S$ ramp of Dulles Airport Access Road with Reston Avenue, Reston, NW Vienna quadrangle, Fairfax County, Va.

Richmond Gneiss

1. Precambrian, early

2. Minnesota (C)

3. Morey, G. B., 1978, Lower and middle Precambrian stratigraphic nomenclature for east-central Minnesota: Minnesota Geol. Survey Rept. Inv. 21, p. 7-9

4. Feldspar-quartz-hypersthene-hornblende gneiss with porphyroblasts of K-feldspar and lenses of biotite schist and amphibolite

5. Black to grayish-black, oxidizes reddish gray to pale red

7. Vaguely foliated

9. Intruded on $\mathbf{E}$ by Stearns Granite Complex; unconformably underlies Cretaceous sedimentary rocks to $\mathrm{W}$ and $\mathrm{S}$

10. Type locality reported by Morey (1978) is incorrect. Corrected type locality: SW1/4SW1/4 sec. 20, and NW1/4NW1/4 sec. 29 , T. 123 N., R. 30 W., Wakefield Township, Stearns County, Minn. (Dacre, G. A., Himmelberg, G. R., and Morey, G. B., 1984, Pre-Penokean igneous and metamorphic rocks, Benton and Stearns Counties, central Minnesota: Minnesota Geol. Survey Rept. of Inv. no. 31, p. 3.) Named for exposures along Sauk River valley near town of Richmond.

Ridgeland Formation (Lake Bonneville Group)

1. Holocene

2. Utah (NC)

3. Van Horn, Richard, 1979, The Holocene Ridgeland Formation and associated Decker Soil (new names) near Great Salt Lake, Utah: U.S. Geol. Survey Bull. 1457-C, p. C1-C11

4. Silt, clay

5. Gray to dark-brown

6. $0.51 \mathrm{~m}$, range $0.15-1.90 \mathrm{~m}$

7. Massive, calcareous, tastes slightly salty, fossiliferous

9. Unconformably overlies Midvale Soil, which is formed on Draper Formation (Lake Bonneville Group); grades into overlying Decker Soil (formed on Ridgeland Formation), which lies at surface

10. Type section: Exposures in W bank of Ridgeland Canal, SW1/4SE1/4 sec. 20 , T. 1 S., R. 1 W., Salt Lake City South quadrangle, Salt Lake County, Utah. Named for Ridgeland Canal. 
Ridgepole Mountain Formation (Coweeta Group)

1. Precambrian, late(?) [Late Proterozoic(?)]

2. North Carolina (WC), Georgia

3. Hatcher, R. D., Jr., 1979, The Coweeta Group and Coweeta syncline--major features of the North Carolina-Georgia Blue Ridge: Southeastern Geology, v. 21, no. 1, p. 23

4. Biotite-garnet schist and quartzite, interlayered with pelitic schist and garnetiferous metasandstone

9. Overlies Coleman River Formation (Coweeta Group); upper contact not observed (top eroded)

10. Type area: Exposures on Ridgepole Mountain and Little Ridgepole Mountain, Prentiss quadrangle, Macon County, N.C.

Riggins Mill Member (Clinchfield Formation)

1. Eocene, late

2. Georgia (C)

3. Huddlestun, P. F., and Hetrick, J. H., 1979, The stratigraphy of the Barnwell Group of Georgla: Georgla Geol. Survey Open File Rept. 80-1, p. 11-12, 78-80

4. Sand, limestone

5. Grayish-yellow to pale-yellow

6. $4.1 \mathrm{~m}$, range $<1-5.2 \mathrm{~m}$

7. Unconsolidated, concretionary, fossiliferous

9. Overlies Huber Formation; gradationally underlies Treadwell Member (Clinchfield Formation); grades laterally into undivided weathered and leached Clinchfield Formation

10. Type locality: Georgia Kaolin Co. Pit $50,1.2 \mathrm{~km}$ SW of Riggins Mill Road and community of Treadwell, $2.24 \mathrm{~km} \mathrm{SE}$ of Bibb Twiggs County line, Twiggs County, Ga.

\section{Rio Abajo Formation}

1. Early(?) Cretaceous

2. Puerto Rico (EC)

3. M'Gonigle, J. W., 1977, The Río Abajo, Pitahaya, and Daguao Formations in eastern Puerto Rico: U.S. Geol. Survey Bull. 1435-B, p. B4-B6

4. Andesitic volcaniclastic tuff, breccia, conglomerate, and lava flows

5. Medium-gray to brownish-gray, speckled

6. $>600 \mathrm{~m}$

7. Coarse- to fine-grained crystal and crystal-1ithic tuff, massive to medium-bedded and graded

9. Base and top not exposed; in fault contact with Pitahaya Formation and informal Late Cretaceous Mambiche sequence; may unconformably underlie Pitahaya Formation to $W$ of study area

10. Type area: Exposures in roadcuts and quarry along Highway 924 between 37,500 to $38,200 \mathrm{~N}$. and $217,900 \mathrm{E}$. and in small borrow pit along Route 3 at $35,500 \mathrm{~N}$., and 222,300 E., near Río Abajo, Humacao quadrangle, P.R.

\section{River Bend Formation}

1. Oligocene, middle and late

2. North Carolina (EC)

3. Ward, L. W., Lawrence, D. R., and Blackwelder, B. W., 1978, Stratigraphic revision of the middle Eocene, Oligocene, and lower Miocene--Atlantic Coastal Plain of North Carolina:

U.S. Geol. Survey Bull. 1457-F, D. F10-F13 
4. Limestone, including biocalcarenite, biocalcirudite, and shell hash

5. Light- to medium-gray, grayish-orange

6. $3 \mathrm{~m}$, range $3-150 \mathrm{~m}$

7. Arenaceous, fossiliferous, molluscan molds

9. Unconformably overlies Castle Hayne Formation; unconformably underlies Belgrade Formation or Duplin Formation

10. Type locality: Exposures $0.3 \mathrm{~km}$ above Rhems Landing, L bank of Trent River, just below River Bend, Craven County, N.C.

Riverdale Member (Oahe Formation)

1. Holocene

2. North Dakota (C)

3. Clayton, Lee, Moran, S. R., and Bickley, W. B., Jr., 1976, Stratigraphy, origin, and climatic implications of late Quaternary Upland silt in North Dakota: North Dakota Geol. Survey Misc. Ser., no. 54, p. 6-7

4. Silt, clay, and sand

5. Grayish-brown, brownish-gray

6. $1.1 \mathrm{~m}$

8. Three informal submembers

9. Overlies Pick City Member; lies at surface

10. Type section: Riverdale Section, bluffs of Lake Sakakawea, center sec. 22, T. 147 N., R. 84 W., McLean County, N. Dak. Named for town of Riverdale, $4 \mathrm{~km} \mathrm{~S}$ of Riverdale Section.

Rock Knoll Formation (Deep Lake Group)

1. Early Proterozoic

2. Wyoming (SE)

3. Karlstrom, K. E., and Houston, R. S., 1979, Stratigraphy and uranium potential of Early Proterozoic metasedimentary rocks in the Medicine Bow Mountains, Wyoming: Wyoming Geol.

Survey Rept. Inv. 13, p. 21, 44-45

4. Quartzite interbedded with phyllite and conglomerate

5. Gray

6. $303 \mathrm{~m}$

7. Quartzite, fine-grained; ripple marks and tabular crossbedding; probably shallow-marine deposits

9. Overlies Vagner Formation (Deep Lake Group); underlies Headquarters Formation (Libby Creek Group)

10. Type section: SE face of Rock Creek Knoll, sec.35, T. 17 N., R. 79 W., Medicine Bow Mountains, Carbon County, Wyo.

Rock Spring Formation

1. Oligocene

2. New Mexico (WC)

3. Deal, E. G., and Rhodes, R. C., 1976, Volcano-tectonic structures in the San Mateo Mountains, Socorro County, New

Mexico: New Mexico Geol. Soc. Spec. Pub. 5, p. 52

4. Andesite and latite tuff, lava, breccla

6. Range $200-1,000 \mathrm{~m}$

7. Source of eruption unknown, older than Nogal Canyon cauldron

9. Unconformably overlies Red Rock Ranch Formation; underlies Vicks Peak Rhyolite

10. Type locality: Rock Spring, S San Mateo Mountains, secs. 13,14 , and 26, T. 9 S., R. 6 W., Socorro County, N. Mex. 


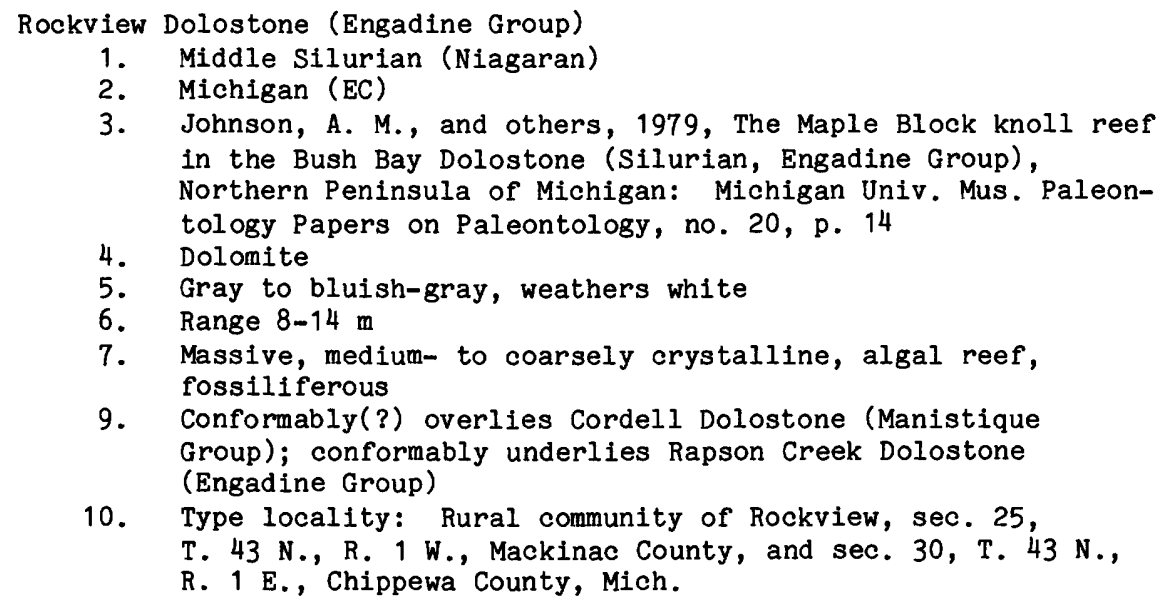

Ronald Member (Lakedale Drift)

1. Pleistocene

2. Washington (C)

3. Porter, S. C., 1976, Pleistocene glaciation in the southern part of the North Cascade Range, Washington: Geol. Soc. America Bull., v. 87 , no. 1, p. 70

4. Till, gravel, sand, silt

7. Moraine, outwash; mantled by loess

8. Till and outwash facies

9. Overlies Bullfrog Member; underlies Domerie Member

10. Type locality: Till facies: cut along $S$ bank of Yakima River, E of U.S. Highway I-90, SE1/4NW1/4 sec. 36, T. $20 \mathrm{~N}$., R. 14 E.; outwash facies: cut along $N$ bank of Yakima River in riser of Ronald terrace, SE1/4SE1/4 sec. 28 , T. $20 \mathrm{~N}$., R. 15 E., Kittitas County, Wash. Named for nearby town of Ronald.

Rookery Bay Formation (Naples Bay Group)

1. Early Cretaceous (Comanchean)

2. Florida (SE)

3. Winston, G. D., 1976, Six proposed formations in the undefined portion of the Lower Cretaceous section in south Florida: Gulf Coast Assoc. Geol. Socs. Trans., v. 26, p. $70-71$

4. Anhydrite with interbedded chalky limestone and dolomite

6. $147 \mathrm{~m}$

7. Thin pelletal micritic limestone at base; thick, regionally persistent anhydrite bed at top

9. Overlies Panther Camp Formation; underlies Corkscrew Swamp Formation

10. Type section: Humble No. 1 Collier Corp. well, depthinterval 2,760-2,907 m, sec. 27, T. 50 S., R. $26 \mathrm{E}$., Collier County, Fla. Named for Rookery Bay along $W$ coast of Florida, $8 \mathrm{~km} \mathrm{SW}$ of type well.

Roosevelt Gabbros (Raggedy Mountain Gabbro Group)

1. Cambrian

2. Oklahoma (C)

3. Powell, B. N., Gilbert, M. C., and Fischer, J. F., 1980, 
Lithostratigraphic classification of basement rocks of the Wichita province, Oklahoma: Summary: Geol. Soc. America Bull., pt. 1, v. 91, no. 9, p. 510-513

4. Biotite-amphibole-olivine gabbro, biotite-amphibole-two pyroxene-gabbro and biotite-gabbro

7. Medium-grained, forms dikes, sills, Irreguhar bodies

8. Glen Creek Gabbro, Sandy Creek Gabbro, Mount Sheridan Gabbro

9. Intrusive into Glen Mountains Layered Complex (Raggedy Mountain Gabbro Group); intruded by Mount Scott Granite

10. Type area: Tps. 3 and 4 N., Rs. 13, 15, $17 \mathrm{~W} .$, Glen and Wichita Comanche and Kiowa Counties, Okla. Named for town of Roosevelt, sec. 6, T. 4 N., R. 17 W., Kiowa County.

Rope Ferry Gnelss (Waterford Group)

1. Late Proterozoic

2. Connecticut (SE)

3. Goldsmith, Richard, 1980, Stratigraphic names in the New London area, southeastern Connecticut--a revision: U.S. Geol. Survey Bull. 1502-A, p. A96-A99

4. Hornblende-biotite-quartz-plagioclase gneiss

5. Gray

6. $1,130 \mathrm{~m} \max$

7. Lenticularly layered, locally massive

9. Overlies New London Gneiss (Waterford Group); unconformably underlies schist in Hunts Brook with sharp contact

10. Type area: Exposures between Rope Ferry Road and Jordan Cove in town of Waterford, New London County, Conn.

Rosarito Beach Formation

1. Miocene and Pliocene

2. Mexico (NW), California

3. Minch, J. A., 1967, Stratigraphy and structure of the Tijuana-Rosarito Beach area, northwestern Baja California, Mexico: Geol. Soc. America Bull., v. 78, no. 9, p. 11581165

4. Basalt flows and interbedded sandstone, siltstone, mudstone, and bentonitic claystone

6. $360 \mathrm{~m}$

8. Subdivided in Mexico into western block with Mira al Mar and Costa Azul Members, and eastern block with Amado Nervo, Las Glorias, and Los Buenos Members. Not subdivided in California

9. Overlies Eocene rocks or Sweetwater Formation; unconformably underlies San Diego Formation; upper part equivalent to Otay Formation

10. Type section: Designated for each member in TijuanaRosarito Beach area, NW Baja California, Mex.; $0.8 \mathrm{~km} \mathrm{~S}$ of Rancho Miro al Mar; $91 \mathrm{~m} \mathrm{E}$ of Rancho Jose; $2.8 \mathrm{~km} \mathrm{~S}$ of Escuela Amado Nervo; $2 \mathrm{~km} \mathrm{SW}$ of town of La Gloria; and $W$ of Escuela Los Buenos, Mexico.

Rottenwood Creek Quartzite (Sandy Springs Group)

1. Precambrian, late(?), and (or) Paleozoic, early(?)

2. Georgia (NW)

3. Higgins, M. W., and McConnell, K. I., 1978, The Sandy Springs Group and related rocks in the Georgia Piedmont-nomenclature and stratigraphy: U.S. Geol. Survey Bull. 1457-A, p. A104 (Also published in: Georgia Geol. Survey 
Bull. 93, p. 53, 1978)

4. Muscovite-bearing quartzite

6. $50 \mathrm{~m}$

7. Massive, crops out along axial traces of synforms and is absent in many places owing to erosion or nondeposition(?)

9. Gradationally overlies Factory Shoals Formation; uppermost unit of Sandy Springs Group

10. Type area: Exposures along Rottenwood Creek $1000 \mathrm{~m} \mathrm{SE}$ of Akers Mill Road, Sandy Springs quadrangle, Fulton County, Ga.

Roxboro Metagranite

1. Precambrian, late, to Early Cambrian

2. North Carolina (NC)

3. Briggs, D. F., Gilbert, M. C., and Glover, Lynn, III, 1978, Petrology and regional significance of the Roxboro Metagranite, North Carolina: Geol. Soc. America Bull., v. 89, no. 4, p. 511-521

4. Granite, alkali-feldspar granite, and granodiorite facies with phenocrysts of plagioclase, quartz, and perthite

5. Light- to medium-gray

7. Microphaneritic

9. Intrudes late Precambrian and Early Cambrian(?) volcanic and epiclastic rocks

10. Type area: Roxboro quadrangle, Person County, N.C.

Ruff Formation (Salina Group)

1. Late Silurian

2. Michigan (SE)

3. Budros, Ron, and Briggs, L. I., 1977, Depositional environment of Ruff Formation (Upper Silurian) in southeastern

Michigan: Am. Assoc. Petroleum Geologists Studies in Geology, no. 5, p. 53-71

4. Calcitic to dolomitic mudstone, anhydrite

5. Brown to dark-grayish-brown, white anhydrite

7. Foreslope shelf deposits

8. Informal lithofacies A through $\mathrm{E}$ : microlaminated mudstone, leached mudstone, pelletal wackestone-packstone, thinly laminated mudstone, nodular anhydrite

9. Overlies informal A-1 evaporite unit of Salina Group; underlies A-2 evaporite unit. Former informal $\mathrm{A}-1$ carbonate unit

10. Type section: Consumers Power Co., 1-36 Ruff well, SE1/4SW1/4NE1/4 sec. 36, T. 5 N., R. 16 E., St. Clair County, Mich.

Rumsey Formation

1. Late Cretaceous

2. California (NW)

3. Ingersoll, R. V., Rich, E. I., and Dickinson, W. R., 1977, Field guide--Great Valley Sequence, Sacramento Valley:

Geol. Soc. America, Cordilleran Sec., Ann. Mtg., [Guidebook $8]$, p. $28,34-36$

4. Concretionary sandstone, siltstone, shale

5. Gray

6. $915 \mathrm{~m}$, range $365-1,220 \mathrm{~m}$

7. Massive to well-bedded, fine- to medium-grained sandstone; laminated siltstone; felsic plutonic detritus deposited in deep-marine trough 
8. Guinda Sandstone Member at base

9. Overlies Cortina Formation; unconformably underlies Tertiary or Quaternary rocks

10. Type section: Exposures along Petroleum Creek and Salt Creek, T. $12 \mathrm{~N} ., \mathrm{R}, 3 \mathrm{~W} ., \mathrm{N}$ end of Rumsey Hills, Rumsey quadrangle, Yolo County, Calif.

Rush Brook Member (Loch Raven Schist)

1. Cambrian-Ordovician(?)

2. Maryland (NC)

3. Crowley, W. P., 1976, The geology of the crystalline rocks near Baltimore and its bearing on the evolution of the eastern Maryland Piedmont: Maryland Geol. Survey Rept. Inv. 27, p. $10-11,23-24$

4. Interlayered biotite-feldspar-quartz gneiss, biotitefeldspar-quartz schist, muscovite-biotite-feldspar-quartz schist

6. Range $<1-600 \mathrm{~m}$

7, Fine-grained

9. Overlies Cockeysville Marble; underlies main body of Loch Raven Schist as discontinuous basal unit

10. Type locality: Outcrops along Rush Brook, tributary of Loch Raven Reservoir, from Loch Raven Road $S$ for $155 \mathrm{~m}$, Baltimore County, Md.

\section{Rushmere Member (Yorktown Formation)}

1. Pliocene, early

2. Virginia (SE), North Carolina

3. Ward, L. W., and Blackwelder, B. W., 1980, Stratigraphic revision of upper Miocene and lower Pliocene beds of the Chesapeake Group, Middle Atlantic Coastal Plain: U.S. Geol. Survey Bull. 1482-D, p. D36-D40

4. Shelly sand, sandy clay

5. Blue-gray

6. $1.1 \mathrm{~m}$

7. Well-sorted, fine-grained

9. Conformably overlies Sunken Meadow Member; conformably underlies Morgarts Beach Member

10. Type locality: Exposures $0.7 \mathrm{~km} \mathrm{E}$ of Rushmere, $\mathrm{R}$ bank of James River, Isle of Wight County, Va. Named for beds at Burwell Bay near Rushmere.

Sabot Amphibolite

1. Precambrian, late, and (or) Early Cambrian

2. Virginia (EC)

3. Poland, F. B., Glover, Lynn, III, and Mose, D. G., 1979, The geology of the rocks along the James River between Sabot and Cedar Point, Virginia, in Glover, Lynn, III, and Tucker, R. D., eds., Virginia Piedmont geology along the James River from Richmond to the Blue Ridge--Field trip 1, of Guides to field trips 1-3: Blacksburg, Va., Geol. Soc. America, Southeastern Sec., p. 11

4. Amphibolite intercalated with biotite gneiss

7. Massive, homogeneous; flanks NNE-trending antiform occupied by State Farm Gneiss

9. Structurally overlies State Farm Gneiss; structurally underlies Maidens Gneiss

10. Type area: Exposures along James River at village of Sabot 
and midway between Sabot and Cedar Point, Goochland County, Va.

\title{
Saddle Peak Member (Topanga Canyon Formation) \\ 1. Miocene, middle \\ 2. California (SC) \\ 3. Yerkes, R. F., and Campbell, R. H., 1979, Stratigraphic nomenclature of the central Santa Monica Mountains, Los Angeles County, California: U.S. Geol. Survey Bull. 1457-E, p. E16 \\ 4. Sandstone, sandy siltstone, basal conglomerate \\ 6. $220 \mathrm{~m}$ \\ 7. Sandstone, thick-bedded to massive, medium- to coarse- grained, pebbly, fossiliferous \\ 9. Conformably overlies Piuma Member (Sespe Formation); con- formably underlies Fernwood Member (Topanga Canyon Formation) \\ 10. Type locality: Roadcuts along Pluma Road, NE1/4 sec. 21, T. 1 S., R. 17 W., SW of Saddle Peak, Santa Monica Mountains, Malibu Beach quadrangle, Los Angeles County, Calif.
}

Sandy Formation (Packsaddle Group)

1. Precambrian

2. Texas (C)

3. McGehee, R. V., 1979, Precambrian rocks of the southeastern Llano region, Texas: Texas, Univ., Austin, Bur. Econ. Geology Geol. Circ. 79-3, p. 9-10

4. Leptite, hornblende schist

5. Light-gray, light-pink

6. $700 \mathrm{~m}$

9. Overlies Honey Formation; underlies Rough Ridge Formation. Unit was formerly Honey Creek Member (Packsaddle Formation) of McGehee (1964)

10. Type section: Along Sandy Creek, from near State Highway 71 bridge, Dunman Mountain quadrangle, to near mouth of Cottonwood Creek, Click quadrangle, Llano County, Tex.

\section{Sandy Creek Gabbro (Roosevelt Gabbros)}

1. Cambrian

2. Oklahoma (C)

3. Powell, B. N., Gilbert, M. C., and Fischer, J. F., 1980, Lithostratigraphic classification of basement rocks of the Wichita province, Oklahoma: Summary: Geol. Soc. America Bull., pt. 1, v. 91, no. 9, p. 510-513

4. Biotite-amphibole-two-pyroxene gabbro, ranging from olivineto quartz-rich gabbro

7. Irregular intrusive body

9. Intrusive into Glen Mountains Layered Complex (Raggedy Mountain Gabbro Group); intruded by Mount Scott Granite

10. Type locality: Outcrops near Sandy Creek, NE1/4NW1/4 and NW1/4NE1/4 sec. 9, T. 3 N., R. 15 W., Wichita Mountains, Comanche County, Okla.

\section{Sandy Pond Amphibolite Member (Marlboro Formation)}

\author{
1. pre-Silurian \\ 2. Massachusetts (C) \\ 3. Bell, K. G., and Alvord, D. C., 1976, Pre-Silurian stratig-
}


raphy of northeastern Massachusetts: Geol. Soc. America Mem. 148 , p. 188-189, 205-206, app. 1 (in pocket)

4. Complexly interstratified hornblende amphibolite and actinolitic amphibolite, minor gneiss and schist lenses

5. Dark-greenish-gray

6. $640 \mathrm{~m}$

7. Fine- to coarse-grained, thin-bedded and massive

9. Overlies unnamed lower member of Marlboro Formation; underlies Shawsheen Gnelss

10. Type locality: NE-trending rocky ridges at $S$ and $E$ sides of Sandy Pond, Concord quadrangle, Middlesex County, Mass.

\section{Sandy Springs Group}

1. Precambrian, late(?), and (or) Paleozoic, early(?)

2. Georgia (NW)

3. Higgins, M. W., and McConnell, K. I., 1978, The Sandy Springs Group and related rocks in the Georgia Piedmont-nomenclature and stratigraphy: U.S. Geol. Survey Bull. 1457-A, p. A98-A101 (Also published in: Georgia Geol. Survey Bull. 93, p. 50-53, 1978)

4. Gneiss, schist, quartzite, amphibolite

6. >3,000 m

7. Linear NE-trending ridges generally underlain by quartzite, and valleys and slopes underlain by gneiss, schist, and amphibolite

8. Powers Ferry Formation, with its Mableton Amphibolite Member, Chattahoochee Palisades Quartzite, Factory Shoals Formation, Rottenwood Creek Quartzite

9. Base of group not exposed; in fault contact, for long distances along its SE boundary, with Long Island Creek Gneiss and Yellow Dirt Gneiss

10. Type area: Town of Sandy Springs, Sandy Springs quadrangle, Fulton County, Ga.

San Nicholas Member (Vaqueros Formation)

1. Miocene, early

2. California (SC)

3. Yerkes, R. F., and Campbell, R. H., 1979, Stratigraphic nomenclature of the central Santa Monica Mountains, Los Angeles County, California: U.S. Geol. Survey Bull. 1457-E, p. E12-E13

4. Sandstone

5. Light-gray to bluish-gray

6. $150 \mathrm{~m}$

7. Thick-bedded to massive, cliff-forming, fossiliferous

9. Conformably overlies Danielson Member (Vaqueros Formation); conformably underlies Encinal Member (Topanga Canyon Formation)

10. Type locality: Exposures in San Nicholas Canyon, Santa Monica Mountains, EC Triunfo Pass quadrangle, Los Angeles County, Calif.

Santas Pascuas Member (Lago Garzas Formation)

1. Late Cretaceous (Campanian(?) and Maestrichtian)

2. Puerto Rico (SC)

3. Krushensky, R. D., and Monroe, W. H., 1978, Geologic map of the Pefiuelas and Punta Cuchara quadrangles, Puerto Rico:

U.S. Geol. Survey Misc. Inv. Ser. Map I-1042 
4. Pumiceous lapilli tuff, vitric and vitric crystal tuff, porphyritic lava, and limestone

5. Light-bluish-green, light-medium-green, and pale-yellowishbrown

6. $>350 \mathrm{~m}$

7. Deeply saprolitized

9. Overlies and interbedded with Pastillo Member (Lago Garzas Formation); unconformably underlies Tertiary rocks

10. Type area: From first E-flowing unnamed tributary on Río Cañas, $1.3 \mathrm{~km} \mathrm{~N}$ of Hacienda Batiz, to village of Santas Pascuas, on $\mathrm{N}$ border of Peffuelas quadrangle, P.R.

\section{Santiago Canyon Tuff}

1. Oligocene, late, or Miocene, early

2. Nevada (WC)

3. Bingler, E. C., 1978, Abandonment of the name Hartford Hill Rhyolite Tuff and adoption of new formation names for middle Tertiary ash-flow tuffs in the Carson City-Silver City area, Nevada: U.S. Geol. Survey Bull. 1457-D, p. D17-D19

4. Hornblende-biotite quartz latite tuff

5. Gray-white to gray

6. $>300 \mathrm{~m}$

7. Crystal-vitric, weakly welded to glassy, densely welded vitrophyre; simple cooling unit

9. Disconformably overlies older Tertiary tuffs or unconformably overlies Mesozoic rocks; unconformably underlies Alta Formation

10. Type section: Exposures at mouth of Santiago Canyon, NW1/4 sec. 5, T. 15 N., R. 21 E., New Empire quadrangle, Carson City, Nev.

Sartell Gneiss (Sauk Rapids Metamorphic Complex)

1. Precambrian, early

2. Minnesota (C)

3. Morey, G. B., 1978, Lower and middle Precambrian stratigraphic nomenclature for east-central Minnesota: Minnesota Geol. Survey Rept. Inv. 21, p. 9-10

4. Interlayered quartzofeldspathic gneiss and garnet- and cordierite-bearing biotite gneiss

5. Pinkish-gray and brownish-gray

7. Well-foliated to massive

9. Encloses lenticular bodies of St. Wendel Metagabbro (Sauk Rapids Metamorphic Complex); interlayered to SE with Watab Amphibolite (Sauk Rapids Metamorphic Complex); truncated on SE by intrusive Stearns Granitic Complex; unconformably underlies Cretaceous sedimentary rocks to $W$ and $S$

10. Type locality: Outcrops $N$ of village of Sartell on $E$ side of Mississippi River, SW1/4 sec. 4, T. 36 N., R. 30 W., Benton County, Minn.

Sauk Rapids Metamorphic Complex

1. Precambrian, early

2. Minnesota (C)

3. Morey, G. B., 1978, Lower and middle Precambrian stratIgraphic nomenclature for east-central Minnesota: Minnesota Geol. Survey Rept. Inv. 21, p. 9-11

4. Gneiss, amphibolite, metagabbro

7. Antiforms and synforms with moderate-dipping limbs and 
shallow E-plunging axes

8. Sartell Gneiss, Watab Amphibolite, St. Wendel Metagabbro 10. Type area: Exposures on both sides of Mississippi River N of St. Cloud in St. Wendel and Le Sauk Townships, Stearns County, and in Sauk Rapids and Watab Townships, Benton County, Minn. Named for city of -Sauk Rapids.

\section{Sausbee Fornation}

1. Early Pennsylvanian (Morrowan)

2. Oklahoma (EC)

3. Sutherland, P. K., and Henry, T. W., 1977, Carbonate platform facles and new stratigraphic nomenclature of the Morrowan Series (Lower and Middle Pennsylvanian), northeastern Oklahoma: Geol. Soc. America Bull., v. 88, no. 3 , p. 429-432

4. Limestone interbedded with shale and, in lower part, sandstone and basal conglomerate

6. $33.5 \mathrm{~m}$, range $15.5-61 \mathrm{~m}$

8. Braggs Member, Brewer Bend Limestone Member

9. Unconformably overlies Pitkin Limestone; unconformably underlies McCully Formation

10. Type section: Measured Section 1, W bluff of Arkansas River, 9-183 m S from $W$ end of Webbers Falls Lock and Dam, SW1/4SW1/4SE1/4 sec. 34, T. $13 \mathrm{~N} .$, R. 20 E., and Measured Section $3,0.5 \mathrm{~km} \mathrm{NW}$ of MS 1 along river bluff, S1/2NW1/4SW1/4 sec. 34, T. 13 N., R. 20 E., Muskogee County, Okla. Derivation of name not stated.

Sciota Limestone Member (Fort Cassin Formation)

1. Early Ordovician

2. New York (NE)

3. Fisher, D. W., 1977, Correlation of the Hadrynian, Cambrian and Ordovician rocks in New York State: New York State Mus. Map and Chart Ser., no. 25, p. 62

4. Dolomitic limestone

5. Gray

6. Range $<1-35 \mathrm{~m}$

7. Medium- to thick-bedded, fine- to coarse-grained, fossiliferous

9. Transitionally overlies Ward Siltstone Member; transitionally underlies Providence Island Dolostone Member

10. Type locality: Near abandoned Sciota School, on Washington County Route $10,8.5 \mathrm{~km}$ NNE of intersection of U.S. Highway 4 and New York Highway 22 in Whitehall, Thorn Hill quadrangle, Washington County, N.Y.

\section{Scotts Hill Member (Peedee Formation)}

1. Late Cretaceous

2. North Carolina (SE), South Carolina

3. Ward, L. W., and Blackwelder, B. W., 1979, Scotts Hill Member (new name) of the Cretaceous Peedee Formation of southeasternmost North Carolina and east-central South Carolina: U.S. Geol. Survey Bull. 1482-A, p. A87-A88

4. Sandy pelecypod biosparrudite, quartz arenite

6. Range $<1-27 \mathrm{~m}$

9. Unconformably underlies Castle Hayne Formation; upper contact is Cretaceous-Tertiary boundary

10. Type area: Outcrops only along NE Cape Fear River near town 
of Scotts Hill, New Hanover County, N.C. Present in subsurface of adjoining counties, including Pender County.

\section{Sedan Formation (Livingston Group)}

1. Late Cretaceous

2. Montana (SC)

3. Skipp, Betty, and McGrew, L. W., 1977, The Maudlow and Sedan Formations of the Upper Cretaceous Livingston Group on the west edge of the Crazy Mountains basin, Montana: U.S. Geol. Survey Bull. 1422-B, p. B3-B20

4. Sandstone, mudstone, conglomerate, interbedded with mudflow conglomerate and tuff

5. Gray

6. $1,076 \mathrm{~m}$, range $915-1,372 \mathrm{~m}$

7. Nonmarine epiclastic volcanic sediments

8. Lower sandstone, welded tuff, middle sandstone, and mudstone members, Bearpaw Shale Member, Lennep Sandstone Member

9. Disconformably to gradationally overlies Eagle Sandstone; conformably underlies Billman Creek Formation (Livingston Group)

10. Type section: Secs. $6,7,17$, and 18, T. 4 N., R. 8 E., SE corner Sixteen NE quadrangle and NE corner Wallrock quadrangle, Park County, Mont. Named for hamlet of Sedan on $E$ flank of Bridger Range.

\section{Sedgefield Member (Tabb Formation)}

1. Pleistocene, late

2. Virginia (SE)

3. Johnson, G. H., 1976, Geology of the Mulberry Island, Newport News North, and Hampton quadrangles, Virginia:

Virginia Div. Mineral Resources Rept. Inv. 41, p. 33-35

4. Clayey and gravelly sand, clay

5. Gray, tan to yellowish-brown, bluish-gray

6. $3.5 \mathrm{~m}$, range $1-3.5 \mathrm{~m}$

7. Brackish-bay, lagoonal marsh, and nearshore marine deposits; basal fossiliferous, cobbly, clayey, medium to coarse sand

9. Unconformably overlies Yorktown Formation or Norfolk Formation; unconformably underlies Lynnhaven Member (Tabb Formation)

10. Type section: Exposure in Williams Paving Co. sand pit, 0.6 $\mathrm{km} \mathrm{W}$ of Big Bethel Road (State Road 600) and $1.1 \mathrm{~km} \mathrm{~N}$ of U.S. Highway I-64, City of Hampton, Va. Named for settlement of Sedgefield, city of Newport News.

\section{Seward Member (Duperow Formation)}

\section{Late Devonian}

2. Canada (Saskatchewan), Montana

3. Kent, D. M., 1963, The stratigraphy of the Upper Devonian Saskatchewan Group of southwestern Saskatchwan: Saskatchewan Dept. Mineral Resources Rept. 73, p. 21-24

4. Argillaceous limestone, dolomite, shale, and evaporites

5. Varicolored

6. $69 \mathrm{~m}$

7. Fossiliferous, subsurface

9. Conformably overlies Wymark Member (Duperow Formation); conformably underlies Birdbear Formation

10. Type section: Mobil Oil Woodley Sinclair Cantuar No. X-2-21 well, depth-interval 1,391-1,460 m, Lsd. 2-21-16-17W3, 
Saskatchewan, Canada. Named for Seward Forest Reserve, $8 \mathrm{~km}$ $S$ of type well.

\section{Shawsheen Gneiss}

1. pre-Silurian

2. Massachusetts (C)

3. Bell, K. G., and Alvord, D. C., 1976, Pre-Silurian stratigraphy of northeastern Massachusetts: Geol. Soc. America Mem. 148, p. 188-189, 206-207, app. 1 (in pocket)

4. Muscovite-biotite-oligoclase-quartz gneiss with lenticular bodies of amphibolite

5. Medium-gray

6. $2,600 \mathrm{~m}$

7. Medium-grained, ripple-bedded, relict sedimentary structures

9. Overlies Marlboro Formation; underlies Fish Brook Gneiss

10. Type locality: Belt along NW side of Shawsheen River, Billerica and Wilmington quadrangles, and in Harold Parker State Forest, Reading quadrangle, Middlesex County, Mass.

\section{Shellmound Fornation}

1. Late Ordovician

2. Tennessee (SC), Georgia

3. Milici, R. C., and Wedow, Helmuth, Jr., 1977, Upper Ordovician and Silurian stratigraphy in Sequatchie Valley and parts of the adjacent Valley and Ridge, Tennessee: U.S. Geol. Survey Prof. Paper 996, p. 8-9, 20-21

4. Silty glauconitic limestone, overlain by argillaceous limestone, calcisiltite, and calcarenite

5. Gray to greenish-gray

6. $29 \mathrm{~m}$

7. Fossiliferous

8. Fernvale Member

9. Overlies Leipers Formation; underlies Rockwood Formation

10. Type section: Roadcuts along W lane of U.S. Highway I-24 near Shellmound, a few hundred $m \mathrm{~W}$ of Jasper interchange, Marion County, Tenn.

Sherd Lake Till

1. Pleistocene

2. Wyoming (NC)

3. Nelson, R. S., 1977, Glacial deposits of the Lake Angeline quadrangle, Bighorn Mountains, Wyoming: Earth Sci. Bull., v. 10 , no. 1 , p. 16

4. Cobble and boulder till in sand and clay matrix

5. Pinkish, weathers light yellowish brown

6. Range 3-15 m

7. Loose, uncompacted; terminal, recessional, and ground moraines

9. Overlies Circle Park Till; underlies Long Lake Till

10. Type locality: Moraine surrounding Sherd Lake, S1/2 sec. 30 , T. 50 N., R. 84 W., Bighorn Mountains, Johnson County, Wyo.

\section{Shuyak Fornation}

1. Late Triassic

2. Alaska (C)

3. Connelly, William, 1978, Uyak Complex, Kodiak Islands, 
Alaska--a Cretaceous subduction complex: Geol. Soc. America Bull., v. 89 , no. 5, p. $755-769$

4. Pillowed greenstone with interbedded limestone, breccia, agglomerate, and tuff; volcaniclastic turbidites, conglomerate, siliceous tuff, and argillite

6. $>7,000 \mathrm{~m}$

7. Well-bedded, represents seaward margin of lower Mesozoic forearc basin

8. Informal lower volcanic member and upper sedimentary member

9. Structurally overlies Kodiak Islands schist terrane and Uyak Complex but is separated from them by Afognak pluton

10. Type section: N shore of $W$ part of Shuyak Strait, Shuyak Island, $\mathrm{N}$ Kodiak Islands, Alaska.

\section{Sierra Ladrones Formation (Santa Fe Group)}

1. Pliocene, early, to Pleistocene, middle

2. New Mexico (C)

3. Machette, M. N., 1978, Geologic map of the San Acacia quadrangle, Socorro County, New Mexico: U.S. Geol. Survey Geol. Quad. Map GQ-1415

4. Sand, sandstone, silt, fanglomerate, basalt

5. Brown, gray

6. $>470 \mathrm{~m}$

7. Medium- to massively bedded or crossbedded alluvial fan to flood plain deposits; basalt top has pillow lava structure, central part massive, base auto-brecciated

8. Informal basalt, piedmont slope and alluvial fan and axial stream deposit parts

9. Unconformably overlies Popotosa Formation (Santa Fe Group); top eroded

10. Composite type area: Exposures of piedmont slope and alluvial fan deposits just $W$ of Sierra Ladrones, from Rfo Salado to $N$ boundary of Servilleta Grant; axial stream deposit exposures near Loma Blanca; piedmont slope and alluvial flat deposit exposures $N$ and $E$ of San Acacia dam. Named for Sierra Ladrones, Socorro County, N. Mex.

\section{Sierra Madre Granite}

1. Early Proterozoic

2. Wyoming (SC)

3. Divis, A. F., 1976, Geology and geochemistry of Sierra Madre Range, Wyoming: Colorado School Mines Quart., v. 71, no. 3, p. $31-34$

4. Alaskitic granite

5. Pink to red

7. Medium- to fine-grained protoclastic phase; medium- to coarse-grained massive, equigranular phase; porphyritic phase; augen gneiss marginal unit; batholith and dikes

9. Intrudes Big Creek Gneiss and intergrades with it through augen gneiss marginal unit; intruded by white quartz monzonite

10. Type area: Major Proterozoic intrusive rock in Sierra Madre Range, Carbon County, Wyo.

\section{Silver Shield Quartz Latite}

1. Miocene, middle

2. Utah (C)

3. Morris, H. T., and Lovering, T. S., 1979, General geology 
and mines of the East Tintic mining district, Utah and Juab Counties, Utah: U.S. Geol. Survey Prof. Paper 1024,

p. $61-65$

4. Quartz latite

5. Dark-gray

6. Range $2-38 \mathrm{~m}$

7. Coarse-grained, porphyritic; dike and flow unit

9. Intrudes Packard Quartz Latite; intrudes and disconformably overlies Pinyon Creek Conglomerate

10. Type locality: Exposures in SE1/4 sec. 35, T. $9 \mathrm{~S}$., R. 2 W., and adjacent parts of secs. 1 and $2, T .10 \mathrm{~S}$, R. 2 W., NE of Silver Shield (Independence) shaft, East Tintic mining district, NE Eureka quadrangle, Utah County, Utah.

\section{Sinawava Member (Temple Cap Sandstone)}

1. Middle Jurassic

2. Utah (SW)

3. Peterson, Fred, and Pipiringos, G. N., 1979, Stratigraphic relations of the Navajo Sandstone to Middle Jurassic formations in parts of southern Utah and northern Arizona: U.S. Geol. Survey Prof. Paper 1035-B, p. B8-B9

4. Sandstone interbedded with silty sandstone and mudstone

5. Reddish-brown

6. $6.1 \mathrm{~m}$, range $2.4-113.4 \mathrm{~m}$

7. Very fine to fine-grained, some beds contain scattered coarse grains or small pebbles; slope-forming

9. Unconformably(?) overlies Navajo Sandstone (Glen Canyon Group); underlies White Throne Member (Temple Cap Sandstone)

10. Type section: At top of Zion Canyon about $500 \mathrm{~m} \mathrm{NE}$ of observation Point, NW1/4NW1/4 sec. 2, T. 41 S., R. $10 \mathrm{~W} .$, Zion National Park, Washington County, Utah. Named for Temple of Sinawava in Zion Canyon, $1 \mathrm{~km}$ NW of type section.

\section{Sinepurent Formation}

1. Pleistocene (Wisconsinan)

2. Maryland (SE), Delaware, Virginia

3. Owens, J. P., and Denny, C. S., 1979, Upper Cenozoic deposits of the central Delmarva Peninsula, Maryland and Delaware: U.S. Geol. Survey Prof. Paper 1067-A, p. A22-A24

4. Micaceous sand with beds of black clay and peat

6. $>18 \mathrm{~m}$

7. Sand coarsens upward; marginal marine deposit, fossiliferous

9. Unconformably, from $\mathrm{N}$ to $\mathrm{S}$, overlies Omar Formation, Beaverdam Sand, and so-called "Yorktown(?) and Cohansey(?)" Formations

10. Type locality: Drill holes in Sinepuxent Neck Peninsula between Berlin and Ocean City, Worcester County, Md.

\section{Singatse Tuff}

1. Oligocene

2. Nevada (WC)

3. Proffett, J. M., Jr., and Proffett, B. H., 1976, Stratigraphy of the Tertiary ash-flow tuffs in the Yerington district, Nevada: Nevada Bur. Mines and Geology Rept. 27, p. $19-20$

4. Ash-flow tuff

5. Brown to red-brown 
6. Range $240-460 \mathrm{~m}$

7. Welded, crystal-rich cooling unit; prominent ridge former

9. Overlies Mickey Pass Tuff; underlies Bluestone Mine Tuff with erosional unconformity

10. Type area: N of Singatse Peak, sec. 13, T. 13 N., R. 24 E., Singatse Range, Lyon County, Nev.

\section{Sissel Gulch Graywacke}

1. Ordovician(?)

2. California (NW)

3. Hotz, P. E., 1977, Geology of the Yreka quadrangle, Siskiyou County, California: U.S. Geol. Survey Bull. 1436, p. 12-14

4. Graywacke

5. Greenish-gray

6. Range $600-700 \mathrm{~m}$

7. Fine-grained, hard; faint parting plane parallel to bedding

9. Overlies greenschist on thrust fault; conformably(?) underlies Duzel Phyllite

10. Type locality: Upper Moffett Creek drainage, including Sissel Gulch, from SW1/4 sec. $32, T .43$ N., R. 7 W., to $\mathrm{S}$ boundary of Yreka quadrangle, sec. 7, T. $42 \mathrm{~N} ., \mathrm{R} .7 \mathrm{~W}$. , Siskiyou County, Calif.

Sisson Member (St. Louis Limestone)

1. Late Mississippian

2. Indiana (SW)

3. Keller, S. J., and Becker, L. E., 1980, Subsurface stratigraphy and oil fields in the Salem Limestone and associated rocks in Indiana: Indiana Geol. Survey Occasional Paper 30, p. $11-15$

4. Calcarenite limestone facies interbedded with dolomite, shale, evaporite, and crystalline limestone

5. Tan

6. $37 \mathrm{~m}$

7. Medium-grained, fossiliferous

9. Overlies Salem Limestone; underlies St. Louis Limestone

10. Type section: $T$ \& $H$ No. 1 Lane well, depth-interval 640$677 \mathrm{~m}$, sec. 10, T. 1 N., R. 10 w., Knox County, Ind. Named for small community of Sisson in sec. 7, T. $1 \mathrm{~N} .$, R. $10 \mathrm{~W}$.

\section{Skillern Chert Member (Rockwood Formation)}

1. Early Silurian

2. Tennessee (SC)

3. Milici, R. C., and Wedow, Helmuth, Jr., 1977, Upper Ordovician and Silurian stratigraphy in Sequatchie Valley and parts of the adjacent Valley and Ridge, Tennessee: U.S. Geol. Survey Prof. Paper 996, p. 9, 23-24

4. Chert interbedded with sandy limestone

5. Gray-green to gray-brown limestone, gray to black chert

6. $13 \mathrm{~m}$

7. Uneven bedding, some chert nodules

9. In lower part of Rockwood Formation

10. Type section: Exposures along Skillern Creek and its tributaries and in Skillern Cove along Tennessee Highway 30 , about $5 \mathrm{~km}$ SE of Pikeville, Bledsoe County, Tenn. 
Skyline Trail Conglomerate Member (Hoback Formation)

1. Paleocene, late, or Eocene, early

2. Wyoming (WC)

3. Dorr, J. A., Jr., Spearing, D. R., and Steidtmann, J. R., 1977, Deformation and deposition between a foreland uplift and an impinging thrust belt--Hoback Basin, Wyoming: Geol. Soc. America Spec. Paper 177, p: 15-20

4. Conglomerate with lenses of clay and silt

5. Red matrix

6. $500 \mathrm{~m}$

7. Coarse clasts in sparse clay and silt matrix; alluvial-fan deposit

9. Conformably overlies main body of Hoback Formation on NW margin of Hoback Basin; unconformably underlies patches of Pleistocene moraine

10. Type area: Exposures in high, narrow valley between Hoback and Gros Ventre Ranges, extending from $W$ side of Granite Creek NW to headwater area of North Fork of Horse Creek, along Skyline Trail, T. 39 N., R. 113 W., to T. 40 N., R. 115 W., Teton County, Wyo.

Slaughterhouse Gneiss

1. Precambrian, late

2. Maryland (NC)

3. Crowley, W. P., 1976, The geology of the crystalline rocks near Baltimore and its bearing on the evolution of the eastern Maryland Piedmont: Maryland Geol. Survey Rept. Inv. 27, p. $5-6,21$

4. Microcline-quartz-plagioclase granitic gneiss

5. Pink- to orange-weathering

7. Medium-grained, uniform, well-follated to massive; of probable pre-Glenarm intrusive origin

9. Forms three discrete masses within Baltimore Gnelss

10. Type locality: Outcrops along Slaughterhouse Branch SE of Baltimore Beltway, U.S. Highway I-695, Cockeysville quadrangle, Baltimore County, Md.

Slaughterhouse Marble (Libby Creek Group)

1. Early Proterozoic

2. Wyoming (SC)

3. Divis, A. F., 1976, Geology and geochemistry of Sierra Madre Range, Wyoming: Colorado School Mines Quart., v. 71, no. 3, p. $27-28$

4. Siliceous marble with interbedded phyllite and calcitic schist

6. $300 \mathrm{~m}$

7. Massive, fine- to medium-grained

9. Lithologically similar to Nash Fork Formation (Libby Creek Group) in Medicine Bow Range; conformably overlies Quartzite Peak Quartzite; uppermost formation of Libby Creek Group with irregular top bounded by low-angle faults

10. Type area: Exposed in Slaughterhouse Gulch $\mathrm{N}$ of North Fork of Encampment River, Sierra Madre Range, Carbon County, Wyo.

Slope Formation (Fort Union Group)

1. Paleocene

2. North Dakota (SW), Montana

3. Clayton, Lee, and others, 1977, The Slope (Paleocene) and 
Bullion Creek (Paleocene) Formations of North Dakota: North Dakota Geol. Survey Rept. Inv. 59, p. 7-9

4. Alternating beds of clay, silt, sand, and lignite

5. Brownish-gray, bleached white at top

6. $90 \mathrm{~m}$

7. Unlithified or moderately lithified; unbedded or thinly laminated

8. Informal white marker zone at top of slope Formation

9. Overlies Cannonball or (at type section) Ludlow Formation; unconformably underlies Bullion Creek Formation

10. Type section: S-facing exposure in NW1/4 sec. 10 , T. 105 N., R. 135 W., Slope County, N. Dak. Named for Slope County.

Smelser Pass Member (Augusta Mountain Formation)

1. Middle and Late Triassic (Ladinian and Karnian)

2. Nevada (NC)

3. Nichols, K. M., and Silberling, N. J., 1977, Stratigraphy and depositional history of the Star Peak Group (Triassic), northwestern Nevada: Geol. Soc. America Spec. Paper 178, p. $31-34$

4. Limestone capped by mafic volcanic rocks

5. Dark-gray, mottled

6. $180 \mathrm{~m}$, range $180-400 \mathrm{~m}$

7. Medium- to thick-bedded, bioturbated, blocky weathering, cliff-forming, intertidal to subtidal deposits

9. Conformably overlies Panther Canyon Member (Augusta Mountain Formation); unconformably underlies Cane Spring Formation (both formations are in Star Peak Group)

10. Type section: Near Smelser Pass, $\mathbf{N}$ end of China Mountain, T. 32 N., R. 40 E., Pershing County, Nev.

Smeltertown Formation (Washita Group)

1. Early Cretaceous (Comanchean)

2. New Mexico (SC), Texas, Mexico

3. Strain, W. S., 1976, New formation names in the Cretaceous at Cerro de Cristo Rey, Dona Ana County, New Mexico, Appendix 2, in Lovejoy, E. M. P., Geology of Cerro de Cristo Ray uplift, Chihuahua and New Mexico: New Mexico Bur. Mines and Mineral Resources Mem. 31, p. 78-79

4. Shale with interbedded sandstone, siltstone, and limestone

5. Olive-gray, dark-gray

6. $61.4 \mathrm{~m}$, range $30-61.4 \mathrm{~m}$

7. Sole marks common

9. Conformably overlies Del Norte Formation; conformably underlies Muleros Formation

10. Type section: $\mathrm{N}$ side of arroyo trending $\mathrm{S} 70^{\circ} \mathrm{W}$ from kilns at El Paso Brick Co. plant, NW1/4SW1/4NW1/4 sec. 15 and SE1/4SE1/4NE1/4 sec. 16, T. 29 S., R. 4 E., Doha Ana County, N. Mex. Named for community of Smeltertown in El Paso, El Paso County, Tex.

Smutty Hollow Member (Ammonoosuc Formation)

1. Middle Ordovician

2. New Hampshire (WC)

3. Prager, G. D., 1980, Stratigraphy of the Gardner Mountain area, New Hampshire: Northeastern Geology, v. 2, no. 1, p. 34 
4. Calcareous chlorite schist

5. Blue-gray

7. Massive

9. Overlies West Bath Member (Ammonoosuc Formation); underlies Partridge Formation

10. Type locality: In Smutty Hollow Brook, $0.4 \mathrm{~km} \mathrm{E}$ of Connecticut River, Grafton County, N.H.

\section{Snaky Canyon Formation}

1. Late Mississippian to Early Permian (Chesterian to Wolf campian)

2. Idaho (SE)

3. Skipp, Betty, and others, 1979, Upper Paleozoic carbonate bank in east-central Idaho--Snaky Canyon, Bluebird Mountain, and Arco Hills Formations, and their paleotectonic significance: U.S. Geol. Survey Bull. 1486, p. 20-32

4. Limestone and dolomite, locally oolitic and cherty, interbedded with calcareous sandstone

5. Medium- to light-gray

6. $1,300 \mathrm{~m}$

7. Medium- to thin-bedded, microcrystalline to medium-grained, variably fossiliferous

8. Bloom, Gallagher Peak Sandstone, and Juniper Gulch Members

9. Gradationally overlies Bluebird Mountain Formation; conformably underlies Phosphoria Formation

10. Type section: Designated for each member. Named for Snaky Canyon, Snaky Canyon quadrangle, Clark County, Idaho.

Sneakover Limestone Member (Orr Formation)

1. Late Cambrian

2. Utah (WC)

3. Hintze, L. F., and Palmer, A. R., 1976, Upper Cambrian Orr Formation--its subdivisions and correlatives in western

4. Calcarenite, calcisiltite

5. Gray

6. $56.4 \mathrm{~m}$, range $50-60 \mathrm{~m}$

7. Fossiliferous, ledge-forming

9. Conformably overlies Corset Spring Shale Member or Steamboat Pass Shale Member (Orr Formation); conformably underlies Notch Peak Formation

10. Type section: NE side of Orr Ridge, along ridge between Little Horse Canyon and Big Horse Canyon, NE1/4 sec. 33, T. 18 S., R. 13 W., House Range, Notch Peak quadrangle, Millard County, Utah. Named for Sneakover Pass in House Range.

Solon Formation

1. Early Devonian(?)

2. Maine (WC)

3. Pankiwskyj, K. A., and others, 1976, Stratigraphic relationships on the southeast limb of the Merrimack synclinorium in central and west-central Maine: Geol. Soc. America Mem. 146, p. 270, 275

4. Metapelite with minor metasiltstone, metasandstone, and metaconglomerate

5. Silvery-gray

6. $>2,000 \mathrm{~m}$ 
7. Massive to rhythmically interbedded and thinly laminated

9. Conformably and gradationally overlies. Fall Brook Formation; upper contact not exposed (top eroded)

10. Type locality: Tops and slopes of Whipple and French Hills, Township of Solon, N Anson quadrangle, Somerset County, Maine.

Solstice Canyon Tongue (Conejo Volcanics)

1. Miocene, middle

2. California (SC)

3. Yerkes, R. F., and Campbell, R. H., 1979, Stratigraphic nomenclature of the central Santa Monica Mountains, Los Angeles County, California: U.S. Geol. Survey Bull. 1457-E, p. E23

4. Basaltic and andesitic flows, breccias, and tuffs

6. $244 \mathrm{~m}$

9. Overlies Latigo Canyon Breccia Member (Calabasas Formation); intertongues with Dry Canyon Sandstone Member (Calabasas Formation); underlies Malibu Bowl Tongue (Conejo Volcanics)

10. Type area: Solstice Canyon, Santa Monica Mountains, EC Point Dume quadrangle, Los Angeles County, Calif.

\section{Spencer Brook Member (Nashoba Formation)}

1. pre-Silurian

2. Massachusetts (C)

3. Bell, K. G., and Alvord, D. C., 1976, Pre-Silurian stratigraphy of northeastern Massachusetts: Geol. Soc. America Mem. 148, p. 186-187, 208, app. 1 (in pocket)

4. Amphibolite, minor amphibole-biotite gneiss and calcsilicate rocks

6. $580 \mathrm{~m}$

7. Stratified, relict sedimentary structures

9. Overlies Billerica Schist Member; underlies Tophet Swamp Gneiss Member

10. Type locality: Along NW side of Spencer Brook in town of Carlisle, Billerica quadrangle, Middlesex County, Mass.

\section{Spor Mountain Formation}

1. Miocene, early

2. Utah (WC)

3. Lindsey, D. A., 1979, Geologic map and cross-sections of Tertiary rocks in the Thomas Range and northern Drum Mountains, Juab County, Utah: U.S. Geol. Survey Misc. Inv. Ser. Map I-1176

4. Beryllium tuff and porphyritic alkali rhyolite

5. Tan, gray, red

6. Lower member: range 20-60 m; upper member: $500 \mathrm{~m} \max$

7. Lower member: stratified vitric tuff and tuffaceous breccia; upper member: flows, domes, and plugs

8. Informal lower beryllium tuff member and upper porphyritic rhyolite member

9. Unconformably overlies Dell Tuff, Drum Mountains Rhyodacite, Paleozoic rocks; unconformably underlies Topaz Mountain Rhyolite and Quaternary sediments

10. Type section: Exposures $E$ of Spor Mountain, secs. 8 and 9, T. 13 S., R. 12 W., Thomas Range, Juab County, Utah. 
Spring Garden Member (Castle Hayne Formation)

1. Eocene, late middle (Claibornian)

2. North Carolina (EC)

3. Ward, L. W., Lawrence, D. R., and Blackwelder, B. W., 1978, Stratigraphic revision of the middle Eocene, Oligocene, and lower Miocene--Atlantic Coastal Plain of North Carolina: U.S. Geol. Survey Bull. 1457-F, p. F9-F10

4. Siliceous biocalcirudite (limestone)

5. Tan to gray

6. $1.95 \mathrm{~m}$, range $1.95-6 \mathrm{~m}$

7. Arenaceous, well-cemented by calcite; fossiliferous (molluscan molds filled with silica)

9. Conformably overlies Comfort Member (Castle Hayne Formation); unconformably underlies River Bend Formation or Duplin Formation

10. Type locality: Spring Garden Landing, $5.2 \mathrm{~km}$ ENE of Jasper, R bank of Neuse River, Craven County, N.C. Reference local1ty: Martin Marietta Co. New Bern quarry, NW of New Bern, Craven County.

Springtime Canyon Quartz Latite

1. Oligocene

2. New Mexico (WC)

3. Deal, E. G., and Rhodes, R. C., 1976, Volcano-tectonic structures in the San Mateo Mountains, Socorro County, New Mexico: New Mexico Geol. Soc. Spec. Pub. 5, p. 53

4. Mixed quartz latite and rhyolite flows with sanidine and plagioclase phenocrysts

6. $>700 \mathrm{~m}$

7. Massive; erupted from Nogal Canyon cauldron

9. Conformably overlies Vicks Peak Rhyolite; youngest rock of Nogal Canyon cauldron flows

10. Type locality: Springtime Canyon, S San Mateo Mountains, Socorro County, N. Mex.

Squirrel Springs Canyon Andesite

1. Oligocene

2. New Mexico (WC)

3. Rhodes, R. C., and Smith, E. I., 1976, Stratigraphy and structure of the northwestern part of the Mogollon Plateau Volcanic Province, Catron County, New Mexico: New Mexico Geol. Soc. Spec. Pub. 5, p. 59

4. Andesite flows

5. Dark-gray to reddish-black

6. $200 \mathrm{~m}$, range $20-200 \mathrm{~m}$

7. Coarsely porphyritic

9. Conformably overlies or interfingers with Tularosa Canyon Rhyolite; underlies Apache Spring Quartz Latite

10. Type section: Tularosa Canyon, sec. 33, T. 6 S., R. 18 W., Catron County, N. Mex. Named for Squirrel Springs Canyon near John Kerr Peak, Catron Tularosa Mountains.

Stagg Creek Member (Doswell Formation)

1. Late Triassic

2. Virginia (EC)

3. Weems, R. E. 1980, Geology of the Taylorsville basin, Hanover County, Virginia: Virginia Div. Mineral Resources Pub. 27, p. 24-25 
4. Sandstone, conglomerate, minor siltstone

5. Grayish-orange, dark-red

6. $232.6 \mathrm{~m}$

7. Massive, coarse-grained

9. Nonconformably overlies Petersburg Granite; conformably underlies Falling Creek Member (Doswell Formation)

10. Type section: Along Stagg Creek, beginning at Hanover Country Club $0.3 \mathrm{~km} \mathrm{~N}$ of Virginia Highway 54 and continuing $S$ to contact with Petersburg Granite, Taylorsville basin, Hanover Academy quadrangle, Hanover County, Va.

\section{Steamboat Pass Shale Member (Orr Formation)}

1. Late Cambrian

2. Utah (WC)

3. Hintze, L. F., and Palmer, A. R., 1976, Upper Cambrian Orr Formation--its subdivisions and correlatives in western Utah: U.S. Geol. Survey Bull. 1405-G, p. G7-G8, G20-G21

4. Shale, limestone (calcisiltite, calcarenite)

5. Gray

6. $260 \mathrm{~m}$

7. Fossiliferous, slope-forming

9. Conformably overlies Big Horse Limestone Member; conformably underlies Sneakover Limestone Member; equivalent of Candland Shale Member and Corset Spring Shale Member where these cannot be mapped separately because Johns Wash Member is absent

10. Reference section: Best exposures known, $0.8 \mathrm{~km}$ W of Lawson Cove Reservoir on E side of Hill 6190, SW1/4 sec. 29, T. 24 S., R. 14 W., Wah Wah Mountains, Frisco Peak quadrangle, Millard County, Utah. Named for exposures on $\mathrm{N}$ side of Steamboat Pass, sec. 19, T. 23 S., R. 13 W., The Barn quadrangle.

\section{Stewart Gulch Tongue (Green River Formation)}

1. Eocene

2. Colorado (NW)

3. Hail, W. J., Jr., 1977, Stewart Gulch Tongue--a new tongue of the Eocene Green River Formation, Piceance Creek basin, Colorado: U.S. Geol. Survey Bull. 1422-E, p. 1-8

4. Marlstone

5. Light-gray

6. $15.2 \mathrm{~m}$, range $3-17 \mathrm{~m}$

7. Forms prominent outcrops

9. One of several units of the Green River Formation which tongue northward into the Uinta Formation and merge southward with the Parachute Creek Member (Green River Formation). Overlies Coughs Creek Tongue; underlies marlstone at Barnes Ridge

10. Type section: SW1/4NE1/4NW1/4 sec. 3, T. 4 S., R. 96 W., about $730 \mathrm{~m} \mathrm{E}$ of road along Middle Fork of Stewart Gulch, tributary of Piceance Creek, and about $150 \mathrm{~m}$ above valley bottom. Rio Blanco County, Colo.

\section{Stokes Canyon Breccia Meaber (Calabasas Formation)}

1. Miocene, middle

2. California (SC)

3. Yerkes, R. F., and Campbell, R. H., 1979, Stratigraphic nomenclature of the central Santa Monica Mountains, Los 
Angeles County, California: U.S. Geol. Survey Bull. 1457-E, p. E22

4. Sedimentary breccia

6. $60 \mathrm{~m}$

7. Consists of angular fragments of redeposited sandstone that carry Paleocene and Eocene mollusks

9. Prominent interbed in Calabasas Formation, which is otherwise undivided in Stokes Canyon area

10. Type locality: Stokes Canyon area, SW1/4 sec. 33, T. 1 N., R. 17 W., and NW1/4 sec. 4, T. 1 S., R. 17 W., NC Santa Monica Mountains, Malibu Beach quadrangle, Los Angeles County, Calif.

\section{Stoney Fork Hember (Breathitt Formation)}

1. Middle Pennsylvanian (Atokan)

2. Kentucky (SE)

3. Ping, R. G., and Rice, C. L., 1979, Stoney Fork Member (new name) of the Breathitt Formation in southeasternmost

Kentucky: U.S. Geol. Survey Bull. 1482-A, p. A70-A76

4. Shale, limestone, siltstone, and sandstone in upward coarsening sequence

5. Medium-dark-gray

6. $10.43 \mathrm{~m}$, range $6-12 \mathrm{~m}$

7. Fossiliferous, contains siderite layers or nodules

9. Overlies Magoffin Member; unconformably underlies unnamed sandstone and coal beds

10. Type section: Strip bench $350 \mathrm{~m}$ SE of Kentucky State Highway 1201 at head of Red Bird Creek, $4.8 \mathrm{~km}$ SW of community of Beverly, Beverly quadrangle, Bell County, Ky. Named for settlement of Stoney Fork, about $8 \mathrm{~km} \mathrm{~S}$ of type section.

Stony Creek Formation

1. Late Jurassic and Early Cretaceous

2. California (NW)

3. Ingersoll, R. V., Rich, E. I., and Dickinson, W. R., 1977, Field guide--Great Valley Sequence, Sacramento Valley: Geol. Soc. America, Cordilleran Sec., Ann. Mtg., [Guidebook $8]$, p. $28-30$

4. Siltstone and mudstone with lenses of sandstone and conglomerate

5. Greenish-gray to black

6. $4,100 \mathrm{~m}$

7. Thin-bedded to laminated siltstone; predominantly andesitic detritus deposited in deep-marine trough; basal unit of Great Valley sequence

8. Informal basaltic sandstone member

9. In fault contact with serpentinite basement rocks; conformably underlies Lodoga Formation, or is locally truncated by its basal Leesville Sandstone Member

10. Type section: Along Stony Creek, $6.4 \mathrm{~km} \mathrm{NE}$ of town of Stonyford, Lodoga quadrangle, Glenn County, Calif.

Stroh Member (Cataract Formation)

1. Middle Silurian

2. Indiana (NE)

3. Rexroad, C. B., 1980, Stratigraphy and conodont paleontology of the Cataract Formation and the Salamonie Dolomite 
(Silurian) in northeastern Indiana: Indiana Geol. Survey Bull. 58, p. 12-14

4. Argillaceous dolomite with thin shale interbeds

5. Tan, brown, green

6. $3.3 \mathrm{~m}$

7. Fine-grained, fossiliferous

9. Unconformably overlies Cabot Head Member (Cataract Formation); conformably underlies Salamonie Dolomite

10. Type section: Northern Indiana Public Service Co. Arden Tubbs No. 1 hole, depth-interval 456-459.3 m, SW1/4SE1/4SW1/4 sec. 27, T. 36 N., R. 12 E., Steuben County, Ind. Named for town of Stroh, $7.2 \mathrm{~km} \mathrm{NW}$ of type section.

St. Wendel Metagabbro (Sauk Rapids Metamorphic Complex)

1. Precambrian, early

2. Minnesota (C)

3. Morey, G. B., 1978, Lower and middle Precambrian stratigraphic nomenclature for east-central Minnesota: Minnesota Geol. Survey Rept. Inv. 21, p. 11

4. Plagioclase-clinopyroxene gneiss

5. Greenish-gray to greenish-black

7. Lenticular bodies 125-300 $\mathrm{m}$ wide and 300-2,000 m long, elongated to $\mathrm{E}$, parallel to follation of enclosing rocks

9. Enclosed in Sartell Gneiss (Sauk Rapids Metamorphic Complex)

10. Type locality: Abandoned quarry, SE1/4SE1/4 sec. 12, T. 125 N., R. 29 W., St. Wendel Township, Stearns County, Minn.

Sumas Mountain Subgroup (Chilliwack Group)

1. Devonian

2. Washington (NC)

3. Danner, W. R., 1977, Paleozoic rocks of northwest Washington and adjacent parts of British Columbia, in Stewart, J. H., and others, eds., Paleozoic paleogeography of the western United States--Pacific Coast Paleogeography Symposium 1 [Bakersfield, Calif., 1977]: Los Angeles, Soc. Econ. Paleontologists and Mineralogists, Pacific Sec., p. 487-489

4. Limestone, with shale, graywacke, argillite, and volcanic rocks

6. Range 610-915 m

7. Limestone: fossiliferous, argillaceous micrite, layered skeletal reefs; isoclinal folds, imbricate faults

9. Lowest division of Chilliwack Group; lower contact not stated; underlies Red Mountain Subgroup

10. Type area: Doaks Creek quarry on E side of Red Mountain, and quarry exposures on Sumas Mountain, Whatcom County, Wash.

\section{Sunken Meadow Member (Yorktown Formation)}

1. Pliocene, early

2. Virginia (SE), North Carolina

3. Ward, L. W., and Blackwelder, B. W., 1980, Stratigraphic revision of upper Miocene and lower Pliocene beds of the Chesapeake Group, middle Atlantic Coastal Plain: U.S. Geol. Survey Bull. 1482-D, p. D32-D36

4. Shelly sand

5. Tan

6. $2.5 \mathrm{~m}$, range $<1-3 \mathrm{~m}$ 
7. Poorly sorted, coarse- to medium-grained

9. Unconformably overlies Cobham Bay Member (Eastover Formation); conformably underlies Rushmere Member (Yorktown Formation)

10. Type section: Exposures $1.3 \mathrm{~km}$ below mouth of Sunken Meadow Creek, $R$ bank of James River, Surry County, Va.

\section{Sunrise Peak Monzonite Porphyry}

1. Oligocene, middle

2. Utah (C)

3. Morris, H. T., and Lovering, T. S., 1979, General geology and mines of the East Tintic mining district, Utah and Juab Counties, Utah: U.S. Geol. Survey Prof. Paper 1024, p. 41-44

4. Monzonite porphyry

5. Dark-gray to greenish-gray

6. Gough sill: range 152 to $305 \mathrm{~m}$

7. Fine- to medium-grained, stock and sill-like intrusive

- bodies

8. Informal Sunrise Peak stock and Gough sill

9. Intrudes and is genetically equivalent to Tintic Mountain Volcanic Group

10. Type locality: Sunrise Peak stock that underlies Sunrise Peak in SC part of main Tintic mining district, sec. 17, T. 11 S., R. 2 W., $9.6 \mathrm{~km} \mathrm{SSW}$ of Dividend, Juab County, Utah.

\section{Sunset Creek Intrusive Complex}

1. Precambrian, early [Late Archean]

2. Michigan (NW)

3. Schmidt, R. G., 1976, Geology of the Precambrian W (lower Precambrian) rocks in western Gogebic County, Michigan:

U.S. Geol. Survey Bull. 1407, p. 26-28

4. Leucocratic pegmatite, including granitic and aplitic phases, minor quartz monzonite

7. Multitextured pegmatite dikes and small, irregular intrusive bodies; even-textured quartz monzonite dikes

9. Intrusive in Puritan Quartz Monzonite, Whiskers Creek Gneiss, and Ramsay Formation

10. Type locality: Exposures in large bedrock hill, NW1/4NW1/4 sec. 25, T. 47 N., R. 46 W., NE of Sunset Creek, Gogebic County, Mich.

\section{Swauk Prairie Member (Kittitas Drift)}

1. Pleistocene

2. Washington (C)

3. Porter, S. C., 1976, Pleistocene glaciation in the southern part of the North Cascade Range, Washington: Geol. Soc. America Bull., v. 87, no. 1, p. 66-67

4. Stony till, gravel

7. Moraine complex, outwash; mantled by loess

8. Till and outwash facies

9. Overlies Thorp Drift; underlies Indian John Member (Kittitas Drift)

10. Type locality: Till facies: roadcut along U.S. Highway 97 at NW end of Swauk Prairie, SE1/4NW1/4 sec. 28, T. 20 N., R. 17 E., and canal cut on Thorp Prairie, SW1/4NE1/4 sec. 30, T. 19 N., R. 17 E.; outwash facles: roadcut near 
distal margin of Thorp Prairie moraine, SE1/4SW1/4 sec. 32, T. 19 N., R. 17 E., upper Yakima River drainage basin, Kittitas County, Wash.

Sweathouse Amphibolite Member (Oella Formation)

1. Cambrian-Ordovician(?)

2. Maryland (NC)

3. Crowley, W. P., 1976, The geology of the crystalline rocks near Baltimore and its bearing on the evolution of the eastern Maryland Piedmont: Maryland Geol. Survey Rept. Inv. 27, p. 11, 24-25

4. Schist and gneiss interlayered with epidote amphibolite

6. Range <1-700 m

7. Mixed metasedimentary-metavolcanic unit; host rock of Bare Hills Copper deposit

9. Overlies lower unnamed metasedimentary unit of Oella Formation; underlies Sykesville Formation

10. Type locality: Outcrops along Sweathouse Branch, tributary of Gunpowder Falls, E from mouth to Mountvista Road, Baltimore County, Md.

Swede Road Member (Bush Bay Dolostone)

1. Middle Silurian (Niagaran)

2. Michigan (EC)

3. Johnson, A. M., and others, 1979, The Maple Block knoll reef in the Bush Bay Dolostone (Silurian, Engadine Group), Northern Peninsula of Michigan: Michigan Univ. Mus. Paleontology Papers on Paleontology, no. 20, p. 14-18

4. Dolomite

5. Buff-brown

6. $10 \mathrm{~m}$

7. Massive, but weathers to thin beds; fine-grained to finely crystaliine, sandy, interreefal deposits, fossil-poor

9. Overlies Prentiss Creek Member; underlies McKay Bay Member

10. Type locality: Powerline right-of-way and U.S. Steel Corp. property, sec. 10, T. 42 N., R. 1 E., Mackinac County, Mich. Named for Swede Road, which runs along $S$ boundary of sec. 10 .

Tabb Formation

1. Pleistocene, late

2. Virginia (SE)

3. Johnson, G. H., 1976, Geology of the Mulberry Island, Newport News North, and Hampton quadrangles, Virginia:

Virginia Div. Mineral Resources Rept. Inv. 41, p. 32-39

4. Clayey, silty and gravelly sand, clay

5. Gray, bluish-gray, tan, reddish-brown, yellowish-brown

6. Range $<1-3.5 \mathrm{~m}$

7. Beach and nearshore marine and fluvial-estuarine deposits

8. Sedgefield, Lynnhaven, and Poquoson Members

9. Unconformably overlies Norfolk Formation or Yorktown Formation; underlies Holocene sediments

10. Type section: Designated for each member. Named for village of Tabb, York County, Va.

Tadauck Brook Schist

1. pre-Silurian

2. Massachusetts (C) 
3. Bell, K. G., and Alvord, D. C., 1976, Pre-Silurian stratigraphy of northeastern Massachusetts: Geol. Soc. America Mem. 148, p. 184-195, 210-211, app. 1 (in pocket)

4. Aluminous schist interstratified with minor amphibolite and quartzite

5. Medium-dark- to silvery-gray, weathers rusty

6. $920 \mathrm{~m}$

7. Stratified, relict sedimentary structures

9. Lower beds intertongued with, or in fault contact with underlying Nashoba Formation; top truncated by ClintonNewbury fault zone

10. Type locality: Area on both sides of Tadmuck Brook in town of Westford, delineated on SE side by upper forks of brook and on NW side by Lowell Road, Westford quadrangle, Middlesex County, Mass.

Tangle Lakes Formation (Amphitheater Group)

1. Late Triassic

2. Alaska (EC)

3. Stout, J. H., 1976, Geology of the Eureka Creek area, eastcentral Alaska Range: Alaska Div. Geol. and Geophys. Surveys Geol. Rept. 46, p. 12-14

4. Siliceous tuff, agglomerate, pillowed andesite and basalt

5. Green to gray

6. $3,500 \mathrm{~m}$

9. Overlies Paxson Mountain Basalt (Amphitheater Group); underlies Boulder Creek Volcanics (Amphitheater Group); intruded by Fish Lake Complex

10. Type locality: S limb of Amphitheater syncline near Tangle Lakes and upper Delta River, Eureka Creek area, Mount Hayes A-4 and A-5 quadrangles, EC Alaska Range, Alaska.

Ta River Metamorphic Suite (Fredericksburg Complex)

1. Early Cambrian(?)

2. Virginia (EC)

3. Pavlides, Louis, 1980, Revised nomenclature and stratigraphic relationships of the Fredericksburg Complex and Quantico Formation of the Virginia Piedmont: U.S. Geol. Survey Prof. Paper 1146, p. 7-12

4. Amphibole gneiss, biotite gneiss, schist, metagabbro, granitoid rocks

5. Dark-gray to black

7. Foliated

9. Possibly an eastern equivalent of Chopawamsic Formation; in contact with Po River Metamorphic Suite along Spotsylvania lineament; underlies Quantico Formation with angular unconformity

10. Type area: Exposures along Virginia Route 656 which crosses Ta River, SE corner of Brokenburg quadrangle, Spotsylvania County, Va.

Tavernier Tongue (Rebecca Shoal Dolomite)

1. Paleocene

2. Florida (SE)

3. Winston, G. O., 1978, Rebecca Shoal reef-complex (Upper Cretaceous and Paleocene) in south Florida: Am. Assoc. Petroleum Geologists Bull., v. 62, no. 1, p. 124-127

4. Anhedral dolomite 


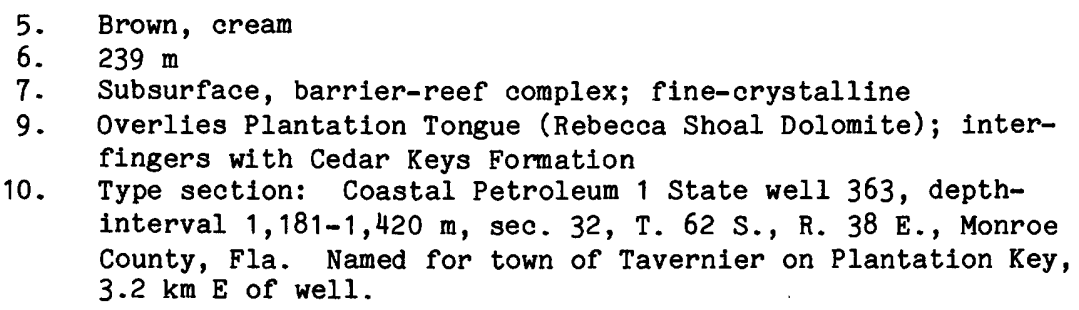

Teklanika Formation

1. Paleocene

2. Alaska (C)

3. Gilbert, W. G., Ferrell, V. M., and Turner, D. L., 1976, The Teklanika Formation--a new Paleocene volcanic formation in the central Alaska Range: Alaska Div. Geol. and Geophys.

Surveys Geol. Rept. 47, p. 1-16

4. Andesite, rhyolite, and basalt flows, with interbedded felsic pyroclastic mudstone, tuff, and tuff breccia

5. Dark-gray, weathers brown and purple

6. >3,750 m

8. Informal units $A, B, C, D, E, F$

9. Conformably and unconformably overlies Cantwell Formation; unconformably underlies Quaternary alluvium

10. Type section: Ridge along $E$ side of upper Teklanika River, from 6.5 to $5 \mathrm{~km} \mathrm{~S}$ of Calico Creek, Mount McKinley National Park, C Alaska Range, Healy C-6 quadrangle, Alaska.

Thiable Limestone Member (Carrara Formation)

1. Early Cambrian

2. California (EC), Nevada

3. Palmer, A. R., and Halley, R. B., 1979, Physical stratigraphy and trilobite biostratigraphy of the Carrara Formation (Lower and Middle Cambrian), southern Great Basin: U.S.

Geol. Survey Prof. Paper 1047, p. 13

4. Limestone

5. Black, brown, and orange

6. Range $\langle 1->50 \mathrm{~m}$

7. Thin-bedded, each bed a couplet: lower part calcarenite, upper part argillaceous or dolomitic; fossiliferous

9. Conformably overlies Eagle Mountain Shale Member; underlies Echo Shale Member

10. Type locality: Exposures on $W$ side of Titanothere Canyon below Thimble Peak, Grapevine Mountains, Inyo County, Calif.

Third Beach Menber (Makah Formation)

1. Eocene, late

2. Washington (NW)

3. Snavely, P. D., Jr., and others, 1980, Makah Formation--a deep-marginal-basin sequence of late Eocene and Oligocene age in the northwestern Olympic Peninsula, Washington: U.S. Geol. Survey Prof. Paper 1162-B, p. 9-11

4. Micaceous sandstone with siltstone interbeds and calcareous concretions

5. Weathers grayish orange

6. $43 \mathrm{~m}$

7. Thick-bedded, amalgamated turbidite beds, ridge-forming

9. Lies $290 \mathrm{~m}$ above Klachopis Point Member and $250 \mathrm{~m}$ below 
Jansen Creek Member; upper and lower contacts with unnamed siltstone and sandstone in middle part of Makah Formation are generally covered

10. Type section: Wave-cut terrace and headland $E$ of Third Beach, SE1/4SW1/4 sec. 7, T. 33 N., R. $14 \mathrm{~W} .$, Strait of Juan de Fuca, Clallam County, Wash.

\section{Thirtyone Formation}

\section{Early Devonian}

2. Texas (WC)

3. Hills, J. M., and Hoenig, M. A., 1979, Proposed type sections for Upper Silurian and Lower Devonian subsurface units in Permian Basin, west Texas: Am. Assoc. Petroleum Geologists Bull., v. 63, no. 9, p. 1513-1518

4. Siliceous limestone, chert

5. Gray, white

6. $308 \mathrm{~m}$, range $30-308 \mathrm{~m}$

9. Unconformably overlies Wristen Formation; unconformably underlies Woodford Shale

10. Type section: Champlin Refining Co. 1 Crane-University well, depth-interval 2,450-2,758 m, Sec. 40, Blk. 31, University Lands Survey, Crane County, Tex. Named for Block 31 oil field.

Thorp Drift

1. Pleistocene

2. Washington (C)

3. Porter, S. C., 1976, Pleistocene glaciation in the southern part of the North Cascade Range, Washington: Geol. Soc. America Bull., v. 87, no. 1, p. 65-66

4. Till; outwash gravel with interbedded sand and silt

6. $140 \mathrm{~m}$ (outwash); $1.5 \mathrm{~m}$ (till)

7. Stony, fissile till, erratios with weathering rinds; poorly sorted, deeply oxidized braided-stream deposits

8. Informal till and outwash facies

9. Unconformably overlies Ellensburg Formation; underlies Kittitas Drift or younger Quaternary deposits

10. Type locality: Till facies: Horse Canyon, $W$ wall at $790 \mathrm{~m}$ alt., NW1/4SW1/4 sec. 4, T. $19 \mathrm{~N},, \mathrm{R}, 17 \mathrm{E}$; outwash facies: landslide scarp on $\mathrm{N}$ side of Yakima River, $1.5 \mathrm{~km} \mathrm{E}$ of Thorp, NE1/4 sec. 12, T. $18 \mathrm{~N} .$, R. $17 \mathrm{E}$, Kittitas County, Wash.

\section{Three Creeks Tuff Member (Bullion Canyon Volcanics)}

\section{Oligocene}

2. Utah (SW)

3. Steven, T. A., and others, 1979, Revised stratigraphy and radiometric ages of volcanic rocks and mineral deposits in the Marysvale area, west-central, Utah: U.S. Geol. Survey Bull. 1469, p. 13-17

4. Crystal-rich ash-flow tuff

6. Lower part: $>200 \mathrm{~m}$; middle part: $200->500 \mathrm{~m}$

7. Compound cooling unit, phenocrystic; hard, densely welded tuffs form vertical cliffs

8. Informal lower, middle, and upper parts

9. As marker bed and only named member, overlies unnamed lower part and underlies unnamed upper part of Bullion Canyon 
Volcanics. Unit was formerly Clear Creek Tuff Member of Dry Hollow Formation

10. Type area: Cliffs along Three Creeks, upstream from mouth of Pole Creek, tributary to Clear Creek, Sevier County, Utah. Reference section: Narrows area of Clear Creek Canyon.

Three Lick Bed (Ohio Shale)/(New Albany Shale)/(Chattanooga Shale)

1. Late Devonian

2. Kentucky (EC), Ohio, West Virginia

3. Provo, L. J., Kepferle, R. C., and Potter, P. E., 1978, Division of black Ohio Shale in eastern Kentucky: Am. Assoc. Petroleum Geologists Bull., v. 62, no. 9, p. 17031713

4. Shale

5. Greenish-gray, black

6. $\quad 3.5 \mathrm{~m}$, range $0.5-22.9 \mathrm{~m}$

7. Plastic, conspicuous lack of silt, thin carbonate layers with cone-in-cone structure, burrowed zones

9. Overlies Huron Member (Ohio Shale); underlies Cleveland Member (Ohio Shale). Overlies and underlies unnamed units of New Albany Shale in EC Kentucky (SW of type locallty), and of Chattanooga Shale in SC Kentucky

10. Type section: Along U.S. Highway I-64, Rowan County, Ky. Base of section on S side of I-64, 2.16 km E of Bath-Rowan County line; top of section on $\mathrm{N}$ side of I-64, $2.8 \mathrm{~km} \mathrm{NE}$ of base. Named for Three Lick Branch, $3 \mathrm{~km} \mathrm{~N}$ of base.

Tick Ridge Sandstone Member (Tar Springs Formation)

1. Late Mississippian (Chesterian)

2. Indiana (SC)

3. Gray, H. H., 1978, Buffalo Wallow Group--upper Chesterian (Mississippian) of southern Indiana: Indiana Geol. Survey Occasional Paper 25, p. 8

4. Sandstone

6. $26 \mathrm{~m}$

7. Crossbedded, massive lenses; cliff-forming

9. Sharp lower and upper contacts with enclosing Tar Springs Formation

10. Type section: Taswell Section, SE1/4 sec. 6, T. 2 S., R. 1 W., Crawford County, Ind. Named for outcrops around Tick Ridge, $4 \mathrm{~km} \mathrm{~S}$ of Taswell.

Tintic Delmar Latite (Laguna Springs Volcanic Group)

1. Oligocene, middle

2. Utah (C)

3. Morris, H. T., and Lovering, T. S., 1979, General geology and mines of the East Tintic mining district, Utah and Juab Counties, Utah: U.S. Geol. Survey Prof. Paper 1024, p. 50-52

4. Latite flows, tuff, ash, agglomeratic breccia

5. Tuff: buff to white; flow: gray

6. Tuff: $23-58 \mathrm{~m}$; flow: $30-61 \mathrm{~m}$

7. Tuff: fine- to coarse-grained, heterogeneous; flow: medium-grained, massive, porphyritic

8. Informal lower tuff member and upper flow member

9. Overlies Pinyon Queen Latite (Laguna Springs Volcanic Group)

10. Type locality: Exposures just $\mathrm{S}$ of Tintic Delmar mine, 
W1/2, sec. 26 , T. 9 S., R. 2 W., SC Allens Ranch quadrangle, Utah County, Utah.

\section{Tintic Mountain Volcanic Group}

1. Oligocene, middle

2. Utah (C)

3. Morris, H. T., and Lovering, T. S., 1979, General geology and mines of the East Tintic mining district, Utah and Juab Counties, Utah: U.S. Geol. Survey Prof. Paper 1024, p. 36-41

4. Latite flows and tuffs

5. Green, gray, black, reddish-brown, white

8. Copperopolis Latite, Latite Ridge Latite, and Big Canyon Latite

9. Unconformably overlies Packard Quartz Latite; unconformably underlies Laguna Springs Volcanic Group or disconformably underlies Pinyon Creek Conglomerate

10. Type locality: Exposures on lower $W$ slopes of Tintic Mountain, $16 \mathrm{~km} \mathrm{~S}$ of Dividend, Juab County, Utah.

Tobacco Road Sand

1. Eocene, late

2. Georgia (EC)

3. Huddlestun, P. F., and Hetrick, J. H., 1978, Stratigraphy of the Tobacco Road Sand--a new formation: Georgia Geol. Survey Bull. 93, p. 56-77

4. Sand with minor chert and limestone

5. Greenish-gray, weathers red

6. $8.5 \mathrm{~m}$, range $3-8.5 \mathrm{~m}$

7. Medium- to coarse-grained, fossiliferous, coastal marine deposits

8. Sandersville Limestone Member at base

9. Gradationally or disconformably overlies Irwinton Sand or Twiggs Clay; disconformably underlies Hawthorn(?) Formation or undivided Tertiary and Quaternary deposits. Unit was former unnamed upper sand member of Barnwell Formation

10. Type locality: E side of Morgan Road, $0.5 \mathrm{~km} \mathrm{~N}$ of junction of Morgan Road and Tobacco Road, Richmond County, Ga.

\section{Tobinsport Formation (Buffalo Wallow Group)}

1. Late Mississippian (Chesterian)

2. Indiana ( $\mathrm{SC}$ )

3. Gray, H. H., 1978, Buffalo Wallow Group--upper Chesterian (Mississippian) of southern Indiana: Indiana Geol. Survey Occasional Paper 25, p. 10-13

4. Shale with interbedded sandstone and limestone

6. $38 \mathrm{~m}$, range $27-38 \mathrm{~m}$

8. Siberia Limestone Member, Bristow Sandstone Member, Mount Pleasant Sandstone Member, Negli Creek Limestone Member; interbedded with unnamed shale beds of Tobinsport Formation

9. Conformably overlies Leopold Limestone Member (Branchville Formation); unconformably underlies Mansfield Formation

10. Type section: Peach Hill Section, NW/14 sec. 34 and SW/14 sec. 27, T. 7 S., R. 2 W., Perry County, Ind. Named for town of Tobinsport.

\section{Togiak Basalt}

1. Quaternary 
2. Alaska (C)

3. Hoare, J. M., and Coonrad, W. L., 1980, The Togiak Basalt, a new formation in southwestern Alaska: U.S. Geol. Survey Bull. 1482-C, p. C1-C11

4. Tholeiite, alkali-olivine basalt

5. Gray, black

6. $<20 \mathrm{~m}$

7. Forms glassy and medium-grained flows and prominent butte; columnar jointing; pillow lava; subglacial tuya deposit

8. Unnamed lower and upper parts

9. Unconformably overlies iron-stained sand and gravel and Mesozoic sedimentary and volcanic rocks; underlies glacial deposits

10. Type section: Exposures on sea cliff $\mathrm{E}$ of Togiak Bay, SW1/4 sec. 1, T. 15 S., R. 66 W., Hagemeister Island D-1 quadrangle, Bristol Bay area, Alaska. Named for Togiak River and Togiak Bay.

Tomany Mountain Formation

\section{Proterozoic}

2. New York (C)

3. McLelland, James, and Isachsen, Yngvar, 1980, Structural synthesis of the southern and central Adirondacks--a model for the Adirondacks as a whole and plate tectonics interpretations: Geol. Soc. America Bull. (pt. 2, microfiche), v.

41, no. 2, p. 224-225

4. Kinzigite (sillimanite-garnet-biotite-quartz-oligoclase gneiss), quartzite, leucogneiss, minor amphibolite

6. Range 300-1,000 m

9. Overlies Lake Durant Formation; underlies Rooster Hill Megacrystic Gneiss

10. Type locality: Tomany Mountain, SW of Averys Place on New York Route 10, Piseco Lake quadrangle, Hamilton County, N.Y.

Tonopah Summit Member (Fraction Tuff)

1. Miocene

2. Nevada (C)

3. Bonham, H. F., Jr., and Garside, L. J., 1979, Geology of the Tonopah, Lone Mountain, Klondike, and northern Mud Lake quadrangles, Nevada: Nevada Bur. Mines and Geology Bull. 92 , p. 50-51

4. Vitric-lithic quartz latite to rhyolite ash-flow tuff

6. Range $60-400 \mathrm{~m}$

7. Nonwelded to weakly welded, hydrothermally altered, in part

9. Unconformably overlies Mizpah Formation; unconformably underlies Siebert Formation, Heller Tuff, King Tonopah Member (Fraction Tuff), and trachyandesite of Red Mountain; intruded by Oddie Rhyolite; intruded and overlain by Brougher Rhyolite

10. Type locality: Low slopes $S$ and SE of Mount Butler and Brock Mountain, secs. 11 and 12, T. 2 N., R. 42 E., near Tonopah Summit, $1.6 \mathrm{~km}$ SE of town of Tonopah, Esmeralda County, Nev.

Tony Grove Lake Member (Laketown Dolostone)

1. Early Silurian

2. Utah (NC), Nevada

3. Budge, D. R., and Sheehan, P. M., 1980, The Upper Ordovician 
through Middle Silurian of the eastern Great Basin--Pt. 1, Introduction--historical perspective and stratigraphic synthesis; Pt. 2, Lithologic descriptions: Milwaukee Public Mus. Contr. Biology and Geology, no. 28, p. 19 (pt. 1); no. 29, p. 6-7 (pt. 2)

4. Dolomite with interbedded conglomerate

5. Light-gray, grayish-black, weathers gray

6. $190 \mathrm{~m}$

7. Microcrystalline to finely crystalline, thin- to thickbedded, banded

9. Overlies informal Bloomington Lake Member (Fish Haven Dolostone); underlies High Lake Member (Laketown Dolostone)

10. Type section: SW1/4SW1/4 sec. 5, T. 13 N., R. 3 E., Tony Grove Lake, Bear River Range, Cache County, Utah.

Topanga Canyon Formation (Topanga Group)

1. Miocene, middle

2. California ( $\mathrm{SC}$ )

3. Yerkes, R. F., and Campbell, R. H., 1979, Stratigraphic nomenclature of the central Santa Monica Mountains, Los Angeles County, California: U.S. Geol. Survey Bull. 1457-E, p. E14-E17

4. Biotitic sandstone, siltstone, and pebbly sandstone

6. $675 \mathrm{~m}$ where undivided

7. Marine, nearshore marine, and nonmarine facies

8. Undivided between Trancas and Malibu Canyons; W of Trancas Canyon: Encinal Member; E of Malibu Canyon: Saddle Peak, Fernwood, and Cold Creek Members

9. Conformably overlies Vaqueros Formation or Sespe Formation; underlies Conejo Volcanics (Topanga Group) or, locally, Calabasas Formation (Topanga Group)

10. Type locality: "Topanga Canyon fauna" locality, roadcuts on OId Topanga Road, SW1/4 sec. 35, T. 1 N., R. 17 W., Santa Monica Mountains, NE corner Malibu Beach quadrangle, Los Angeles County, Calif. Named for Topanga Canyon, which is SE of type locality.

Tophet Swamp Gneiss Nember (Nashoba Formation)

1. pre-Silurian

2. Massachusetts (C)

3. Bell, K. G., and Alvord, D. C., 1976, Pre-Silurian stratigraphy of northeastern Massachusetts: Geol. Soc. America Mem. 148 , p. 186-187, 208, app. 1 (in pocket)

4. Sillimanitic biotite gneiss

5. Medium-gray

6. $920 \mathrm{~m}$

7. Medium-grained, stratified, relict sedimentary structures

9. Overlies Spencer Brook Member; underlies Nashoba Brook Member

10. Type locality: Tophet Swamp in town of Carlisle, Billerica quadrangle, Middlesex County, Mass.

Torquay Formation (Three Forks Group)

1. Late Devonian

2. Canada (Saskatchewan), Montana, North Dakota

3. Christopher, J. E., 1961, Transitional Devonian-

Mississippian formations of southern Saskatchewan:

Saskatchewan Dept. Mineral Resources Rept. 66, p. 15-23 
4. Dolomite, shale, and minor anhydrite in alternating laminated and massive units

5. Banded and mottled gray, brown, green, white

6. $52 \mathrm{~m}$

9. Conformably overlies Birdbear Formation; disconformably underlies Bakken Formation in SE Saskatchewan and NW North Dakota; underlies intervening Big Valley Formation in SW Saskatchewan and NC Montana

10. Type section: Compagnie Francaise des Petroles, Torquay No. 1 well, depth-interval 2,010-2,062 m, Lsd. 8-32-3-11w2, SE Saskatchewan, Canada. Named for town of Torquay.

Towaco Formation (Newark Supergroup)

1. Early Jurassic

2. New Jersey (NE)

3. Olsen, P. E., 1980, The latest Triassic and Early Jurassic formations of the Newark Basin (eastern North America, Newark Supergroup)--stratigraphy, structure, and correlation: New Jersey Acad. Sci. Bull., v. 25, no. 2, p. 36-37

4. Microlaminated calcareous siltstone underlain and overlain by sandstone and siltstone beds and red clastics arranged in fining-upwards cycles

5. Black, gray, red

6. $60 \mathrm{~m}$

7. Symmetrical sedimentary cyclic deposits

9. Overlies Preakness Basalt; underlies Hook Mountain Basalt. Unit was formerly a subdivision of upper part of Brunswick Formation of Kummel (1897)

10. Type section: Essex County Park Commission Dinosaur Tract, Roseland quarry, Roseland, $12 \mathrm{~km} \mathrm{~S}$ of village of Towaco, Essex County, N.J.

\section{Toxaway Gneiss}

1. Precambrian

2. North Carolina (WC), South Carolina

3. Hatcher, R. D., Jr., 1977, Macroscopic polyphase folding illustrated by the Toxaway dome, eastern Blue Ridge, South Carolina-North Carolina: Geol. Soc. America Bull., v. 88, no. 11 , p. 1678-1679

4. Granitic to quartz monzonitic gneiss

7. Banded, forms core of Toxaway structural dome, folded repeatedly

8. Previously named Whiteside Granite

9. Base not exposed; unconformably underlies Tallulah Falls Formation

10. Type locality: Exposures at Toxaway Falls on Toxaway River near Lake Toxaway, Transylvania County, N.C.

\section{Trancas Formation}

1. Miocene, early and middle

2. California (SC)

3. Yerkes, R. F., and Campbell, R. H., 1979, Stratigraphic nomenclature of the central Santa Monica Mountains, Los Angeles County, California: U.S. Geol. Survey Bull. 1457-E, p. E25-E27

4. Sandstone, mudstone, shale, claystone, sedimentary breccia

6. $290 \mathrm{~m}$

7. Intensely folded and faulted, marine, locally fossiliferous 
9. Base not exposed in mapped area; inferred to unconformably overlie Catalina Schist; intertongues with Zuma Volcanics; unconformably underlies and intertongues with Monterey Shale

10. Type locality: Exposures near mouth of Trancas Canyon, Santa Monica Mountains, SW Point Dume quadrangle, Los Angeles County, Calif.

Treadwell Member (Clinchfield Formation)

1. Eocene, late

2. Georgia (C)

3. Huddlestun, P. F., and Hetrick, J. H., 1979, The stratigraphy of the Barnwell Group of Georgia: Georgia Geol.

Survey Open File Rept. 80-1, p. 12-13, 76-78

4. Calcareous sand to sandy limestone

6. $4.1 \mathrm{~m}$

7. Hard limestone and sandstone form ledges between less indurated sand beds; fossillferous

9. Gradationally overlies Riggins Mill Member (Clinchfield Formation); gradationally underlies Tivola Limestone (Ocala Group)

10. Type locality: Georgia Kaolin Company Pit $50,1.2 \mathrm{~km}$ SW of Riggins Mill Road and community of Treadwell, $2.24 \mathrm{~km} \mathrm{SE}$ of Bibb-Twiggs County line, Twiggs County, Ga.

Tuckerton Member (Allentown Formation)

1. Late Cambrian

2. Pennsylvania (SE)

3. MacLachlan, D: B., 1979, Geology and mineral resources of the Temple and Fleetwood quadrangles, Berks County, Pennsylvania: Pennsylvania Geol. Survey, 4 th ser., Atlas 187ab, p. $14-15$

4. Limestone, dolomite, chert

5. Light-gray

6. Range 150-180 m

7. Stromatolitic, oolitic, cyclic deposits

9. Transitionally overlies Leithsville Formation; conformably underlies Muhlenberg Member (Allentown Formation)

10. Type area: Village of Tuckerton on Pennsylvania Route 61, Temple quadrangle, Berks County, Pa.

\section{Tuna Canyon Formation}

1. Late Cretaceous

2. California (SC)

3. Yerkes, R, F., and Campbell, R, H., 1979, Stratigraphic nomenclature of the central Santa Monica Mountains, Los Angeles County, California: U.S. Geol. Survey Bull. 1457-E, p. E4-E7

4. Arkosic sandstone

6. $800 \mathrm{~m}$

7. Thick-bedded, graded, laminated, coarse-grained turbidite, fossiliferous

9. Base not exposed in mapped area; inferred, from exposures to $\mathrm{NE}$, to overlie Santa Monica Slate or Late Cretaceous conglomerate; disconformably(?) underlies Coal Canyon Formation or, locally, intervening Simi(?) Conglomerate

10. Type locality: Tuna Canyon, sec. 30, T. 1 S., R. 16 W., Santa Monica Mountains, WC Topanga quadrangle, Los Angeles County, Calif. 


\section{Twin Spruce Quartz Monzonite}

1. Early Proterozoic

2. Colorado (NC)

3. Gable, D. J., 1980, The Boulder Creek batholith, Front Range, Colorado: U.S. Geol. Survey Prof. Paper 1101, p. 26-35

4. Quartz monzonite, ranges to granite

5. Gray, orange-brown when weathered

7. Fine-grained; breaks into slabby layers that obscure contacts

9. Occupies nearly a quarter of Boulder Creek batholith and is slightly younger than Boulder. Creek Granodiorite

10. Type locality: Just NE of settlement of Twin Spruce where typical quartz monzonite crops out in Coal Creek Canyon, Eldorado Springs quadrangle, Boulder County, Colo.

\section{Underwood Mudflow Breccia}

1. Miocene, early and middle

2. California (C)

3. Axelrod, D. I., 1980, Contributions to the Neogene paleobotany of central California: California Univ. Pubs. Geol. Sci., v. 121, p. 22

4. Hypersthene and augite mudflow breccia

5. Dark-brown to black

6. $60 \mathrm{~m}$

7. Massive, poorly bedded

9. Overlies granitic basement rocks or interfingers with Bear Valley Formation; underlies Relief Peak Formation

10. Type location: Ridges that form $E$ and $W$ walls of Underwood Valley, Alpine County, Calif.

\section{Ursus Member (Kamishak Formation)}

\section{Late Triassic}

2. Alaska (C)

3. Detterman, R. L., and Reed, B. L., 1980, Stratigraphy, structure, and economic geology of the Iliamna quadrangle, Alaska: U.S. Geol. Survey Bull. 1368-B, p. B16-B17

4. Limestone, locally dolomitic, with interbedded chert and tuff

5. Light-gray

6. $>150 \mathrm{~m}$

7. Thin-bedded, fossil fragments; cut by mafic dikes

9. Gradationally overlies unnamed middle member of Kamishak Formation; disconformably underlies Talkeetna Formation; intruded by Jurassic rocks of Alaska-Aleutian Range batholith

10. Type section: Exposures on $\mathrm{S}$ side of Brown Peak, $\mathrm{N}$ of Ursus Cove, Cook Inlet, Iliamna quadrangle, Alaska Peninsula, Alaska.

\section{Utley Limestone Member (Clinchfield Formation)}

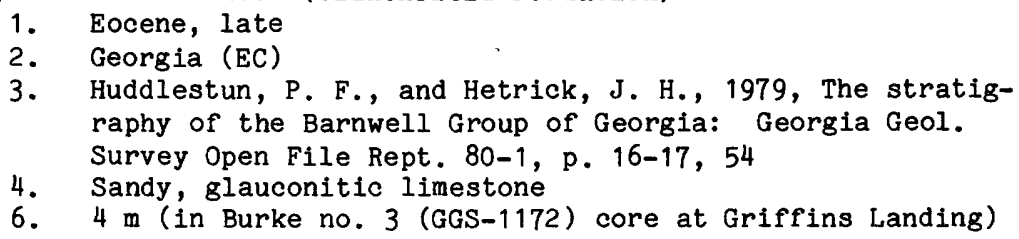


7. Cavernous, fossiliferous; patchy distribution due to deposition in topographic lows or to solution

9. Unconformably overlies Lisbon Formation; underlies Dry Branch Formation (Barnwell Group)

10. Type locality: Utleys Cave at upper end of Mallard Pond, on property of Georgia Power Co. Plant Vogtle site, $2.1 \mathrm{~km} \mathrm{SE}$ of intersection of Hancock Landing Road and River Road, Burke County, Ga.

Vagner Formation (Deep Lake Group)

1. Early Proterozoic

2. Wyoming (SE)

3. Karlstrom, K. E., and Houston, R. S., 1979, Stratigraphy and uranium potential of Early Proterozoic metasedimentary rocks in the Medicine Bow Mountains, Wyoming: Wyoming Geol.

Survey Rept. Inv. 13, p. 19-20, 44

4. Paraconglomerate, marble, phyllite

6. Range 120-400 m

7. Possibly glaciomarine deposits

9. Unconformably overlies Cascade Quartzite; underlies Rock Knoll Formation

10. Type section: W of Vagner Lake, SW1/4 sec. 1, T. $16 \mathrm{~N}$., R. 79 [80] W., Medicine Bow Mountains, Carbon County, Wyo.

\section{Van Buskirk Gneiss}

1. Precambrian, early [Late Archean]

2. Michigan (NW)

3. Schmidt, R. G., 1976, Geology of the Precambrian W (lower Precambrian) rocks in western Gogebic County, Michigan: U.S. Geol. Survey Bull. 1407, p. 14-26

4. Gneiss consisting of interlayered quartz diorite and quartz monzonite

5. Dark- and light-colored banded layers

7. Generally layered, foliated, migmatitic

9. Grades northward into Puritan Quartz Monzonite within Puritan-Van Buskirk pluton

10. Type locality: Exposures in parts of secs. 12 and 13, T. 46 N., R. 47 W., Gogebic County, Mich., near community of Van Buskirk, Iron County, Wis.

Vicks Peak Rhyolite

1. Oligocene

2. New Mexico (WC)

3. Deal, E. G., and Rhodes, R. C., 1976, Volcano-tectonic structures in the San Mateo Mountains, Socorro County, New Mexico: New Mexico Geol. Soc. Spec. Pub. 5, p. 52-53

4. Rhyolite ash-flow tuff, crystal-poor

5. Gray to purple

6. $650 \mathrm{~m}$, range $200-650 \mathrm{~m}$

7. Moderately to densely welded; major ash-flow sheet erupted from Nogal Canyon cauldron

9. Overlies Rock Spring Formation; conformably underlies Springtime Canyon Quartz Latite

10. Type locality: Vicks Peak, S San Mateo Mountains, Socorro County, N. Mex. 
2. Hawaii (SC)

3. Porter, S. C., 1979, Quaternary stratigraphy and chronology of Mauna Kea, Hawail--a 380,000-yr record of mid-Pacific volcanism and ice-cap glaciation: Geol. Soc. America Bull. (pt. 2, microfiche), v. 90, no. 7, p. 1024-1041

4. Alkalic hawaite lavas and pyroclastic cinder cones and tephra layers

6. Range $\langle 30->100 \mathrm{~m}$ for lava flows

7. Long clinkery aa flows and lava domes around vents

9. Unconformably overlies Hopukani and Pohakuloa Formations (Hamakua Group); interstratified with Waihu and Makanaka Formations (Laupahoehoe Group)

10. Type section: Upper Waikahalulu Gulch where W rim of gulch ranges between 2,985 and 3,350 $\mathrm{m}$ alt., Mauna Kea volcano, Hawaii County, Hawail.

Wallace Creek Shale Member (Marcella Formation)

1. Late Mississippian

2. Arkansas (NC)

3. Ogren, D. E., 1968, Stratigraphy of Upper Mississippian rocks of northern Arkansas: Am. Assoc. Petroleum Geologists Bull., v. 52, no. 2, p. 282-292

4. Carbonaceous, siliceous shale

5. Black

6. $18 \mathrm{~m}$, range $<1-18 \mathrm{~m}$

7. Weathers to hard, brittle blocks

9. Conformably overlies Pitkin Limestone; basal unit of Marcella Formation

10. Type section: Exposure along intermittent tributary of Wallace Creek, NW1/4 sec. 12, T. 13 N., R. 9 W., near Marcella, Stone County, Ark.

Vallsburg Ridge Nember (Oquirrh Formation)

1. Late Pennsylvanian (Missourian to Virgilian)

2. Utah (C)

3. Baker, A. A., 1976, Geologic map of the west half of the Strawberry Valley quadrangle, Utah: U.S. Geol. Survey Misc. Inv. Ser. Map I-931, p. 2

4. Quartzite interbedded with limy sandstone and cherty limestone

5. Light-gray, red, blue-gray

6. $2,400 \mathrm{~m}$

7. Fine- to medium-grained; in part finely laminated; fossiliferous (fusulinids)

9. Overlies Shingle Mill Limestone Member; underlies Granger Mountain Member

10. Type locality: Outcrop along crest of Wallsburg Ridge, approximately from Strawberry Valley quadrangle line $E$ to SE1/4 sec. 27, T. 5 S., R. 4 E., Utah County, Utah.

Wanapum Basalt (Yakima Basalt Subgroup of Columbia River Basalt Group)

1. Miocene, middle

2. Washington (C), Oregon, Idaho

3. Swanson, D. A., and others, 1979, Revisions in stratigraphic nomenclature of the Columbia River Basalt Group: U.S. Geol. Survey Bull. 1457-G, p. G25-G37

4. Olivine- and plagioclase-phyric basalt

6. $120 \mathrm{~m}$ 
7. Medium-grained flows

8. Eckler Mountain, Frenchman Springs, Roza, and Priest Rapids Members

9. Conformably and disconformably overlies Grande Ronde Basalt (Yakima Basalt Subgroup) or overlies Vantage Member (Ellensburg Formation); generally conformably underlies Saddle Mountains Basalt (Yakima Basalt Subgroup)

10. Type locality: Exposures along $\mathrm{E}$ side of Columbia River near Wanapum Dam, from Sand Hollow in sec. $28, T .17 \mathrm{~N}$. , R. 23 E., S to top of section near Vantage Substation above Wanapum Dam in sec. 16, T. $16 \mathrm{~N} .$, R. 23 E., Vantage and Beverly quadrangles, Grant County, Wash.

\section{Ward Siltstone Member (Fort Cassin Formation)}

1. Early Ordovician

2. New York (NE), Vermont

3. Fisher, D. W., 1977, Correlation of the Hadrynian, Cambrian and Ordovician rocks in New York State: New York State Mus. Map and Chart Ser., no. 25, p. 64

4. Calcitic and dolomitic siltstone

5. Bluish-gray, weathers tan

6. Range $<1-29 \mathrm{~m}$

7. Thin-bedded, laminated, cross-laminated

9. Overlies Fort Ann Formation; transitionally underlies Sciota Limestone Member (Fort Cassin Formation)

10. Type locality: Near Ward Farm, along Washington County Route $10,7.1 \mathrm{~km}$ NNE of intersection of U.S. Highway 4 and New York Highway 22 in Whitehall, Thorn Hill quadrangle, Washington County, N.Y. Named for Ward Marsh, S of Ward Farm.

Warner Hill Limestone Member (Whitehall Formation)

1. Late Cambrian

2. New York (NE)

3. Fisher, D. W., 1977, Correlation of the Hadrynian, Cambrian and Ordovician rocks in New York State: New York State Mus. Map and Chart Ser., no. 25, p. 51

4. Calcilutite limestone with chert beds

5. Light-gray

6. $27.5 \mathrm{~m}$, range $3-27.5 \mathrm{~m}$

7. Massive-bedded, stromatolite mounds

9. Overlies Finch Dolostone Member; gradationally underlies Skene Dolostone Member

10. Type locality: Abandoned quarry on $\mathrm{N}$ side of Washington County Route 10, $3.2 \mathrm{~km} \mathrm{NE}$ of intersection of U.S. Highway 4 and New York Highway 22 in Whitehall, Whitehall quadrangle, Washington County, N.Y. Named for Warner Hill, $1.6 \mathrm{~km} \mathrm{~N}$ of type locality.

\section{Warrensville Till}

1. Pleistocene (early Wisconsinan)

2. Pennsylvania (C)

3. Wells, R. B., and Bucek, M. F., 1980, Geology and mineral resources of the Montoursville North and Huntersville quadrangles, Lycoming County, Pennsylvania: Pennsylvania Geological Survey, 4 th ser., Atlas $143 \mathrm{~cd}$, p. $24,30,62$

4. Noncalcareous tili consisting of clay, silt, sand, pebbles, and cobbles 
5. Reddish-brown or weak red

6. $30.48 \mathrm{~m}$

7. Unconsolidated, nonstratified, well compacted

9. Overlies Warrensville drift and Muncy Till; underlies Olean Till

10. Type section: Along road connecting Warrensville and U.S. Highway $220,6.4 \mathrm{~km} \mathrm{~S}$ of Warrensville and approximately 0.5 km NE of Edgewood Cemetery, W of Williamsport, lat 41015'17" N., long $76^{\circ} 56^{\prime} 15^{\prime \prime}$ W., Montoursville North quadrangle, Lycoming County, $\mathrm{Pa}$.

Watab Amphibolite (Sauk Rapids Metamorphic Complex)

1. Precambrian, early

2. Minnesota (C)

3. Morey, G. B., 1978, Lower and middle Precambrian stratigraphic nomenclature for east-central Minnesota: Minnesota Geol. Survey Rept. Inv. 21, p. 10-11

4. Hornblende-pyroxene-plagioclase gneiss

5. Black to greenish-black

7. Vaguely foliated, E-trending lenticular mass $3 \mathrm{~km}$ wide and 5 $\mathrm{km}$ long

9. Interlayered to NW with Sartell Gneiss (Sauk Rapids Metamorphic Complex); truncated on SE by intrusive Stearns Granitic Complex

10. Type locality: Abandoned quarry $1 \mathrm{~km} \mathrm{~S}$ of village of Watab, T. 37 N., R. 30 W., Watab Township, Benton County, Minn.

Waterfall Formation

1. Early Jurassic

2. Virginia (NE)

3. Lindholm, R. C., 1979, Geologic history and stratigraphy of the Triassic-Jurassic Culpeper Basin, Virginia: Geol. Soc. America Bull. (pts. 1 and 2), v. 90, no. 11, p. 997 (pt. 1, summary); p. 1725-1732 (pt. 2, microfiche)

4. Interbedded silicate and quartzite conglomerate, sandstone, and shale

6. $1,500 \mathrm{~m}$

7. Fish-bearing lacustrine black calcareous shale beds in upper part

9. Overlies Buckland Formation; in normal-fault contact with older rocks of Blue Ridge on $W$ margin of Culpeper basin

10. Type locality: Exposures in fields NW of community of Waterfall, Culpeper basin, Prince William County, Va.

\section{Waterford Group}

1. Late Proterozoic

2. Connecticut (SE)

3. Goldsmith, Richard, 1980, Stratigraphic names in the New London area, southeastern Connecticut--a revision: U.S. Geol. Survey Bull. 1502-A, p. A96-A99

4. Plagioclase-rich quartz-dioritic and granodioritic gneisses, amphibolite

5. Gray

6. $3,100 \mathrm{~m} \max$

7. Layered, massive

8. Mamacoke Formation, New London Gneiss with its lower Joshua Rock Gneiss Member and upper unnamed granodiorite gneiss member, Rope Ferry Gnelss 
9. Overlies Plainfield Formation; underlies Quinebaug Formation or schist in Hunts Brook

10. Type area: Exposures in town of Waterford, New London County, Conn.

\section{Waukon Member (Jordan Formation)}

1. Late Cambrian

2. Iowa ( $\mathrm{NE})$, Wisconsin

3. Odom, I. E., and Ostrom, M. E., 1978, Lithostratigraphy, petrology, sedimentology, and depositional environments of the Jordan Formation near Madison, Wisconsin: Soc. Econ. Paleontologists and Mineralogists, Great Lakes Sec., 8th Ann. Mtg., Guidebook 3, p. 26, 29

4. Slightly dolomitic feldspathic sandstone

6. $5.5 \mathrm{~m}$

7. Very fine grained, massive to thin-bedded, bioturbated

9. Intertongues with Van Oser Member (Jordan Formation), which underlies and overlies it

10. Type section: $N$ side of Upper Iowa River on Iowa State Road $26 \mathrm{~A}, 1.62 \mathrm{~km} \mathrm{E}$ of Iowa Highway 76 and $16 \mathrm{~km} \mathrm{~N}$ of Waukon, Allamakee County, Iowa.

\section{Weatherby Formation}

1. Early and Middle Jurassic

2. Oregon (EC), Idaho

3. Brooks, H. C., 1979, Geologic map of the Huntington and part of the 0lds Ferry quadrangles, Baker and Malheur Counties, Oregon: Oregon Dept. Geology and Mineral Industries Geol. Map Ser. GMS-13

4. Wacke, siltstone, argillite; less abundant phyllite, slate, conglomerate, limestone

5. Tan, light-gray, olive-green

6. $\leq 7,000 \mathrm{~m}$

7. Pervasive shear cleavage obscures bedding features in most exposures; fossiliferous (ammonites)

8. Jet Creek Member

9. Unconformably overlies Huntington Formation; fault contact with unnamed Paleozoic and Triassic rocks

10. Type section: Exposures along Snake River road, Tps. 12 and 13 S., R. 45 E., Baker County, Oreg. Named for Weatherby, a railroad siding in canyon of Burnt River, sec. 30, T. $12 \mathrm{~S}$. , R. 44 E., Baker County, Oreg.

Weed Heights Member (Mickey Pass Tuff)

1. Oligocene

2. Nevada (WC)

3. Proffett, J. M., Jr., and Proffett, B. H., 1976, Stratigraphy of the Tertiary ash-flow tuffs in the Yerington district, Nevada: Nevada Bur. Mines and Geology Rept. 27, p. $17-19$

4. Silicic dacite, quartz latite, and rhyolite ash-flow tuff, with basal vitrophyre

5. Buff, lavender, reddish-brown

6. $120 \mathrm{~m}$, range $30-180 \mathrm{~m}$

7. Moderately welded, crystal-rich cooling unit; prominent ridge former

9. Overlies Guild Mine Member or intervening unnamed map units 4 or 5 of Mickey Pass Tuff; underlies Singatse Tuff or 
intervening unnamed map unit 7 at top of Mickey Pass Tuff

10. Type area: Exposures $0.8 \mathrm{~km}$ SW of Weed Heights, Singatse Range, Lyon County, Nev.

\section{Weissenfels Ridge Member (Saddle Mountains Basalt) \\ 1. Miocene, middle \\ 2. Washington (SE), Idaho \\ 3. Swanson, D. A., and others, 1979, Revisions in stratigraphic nomenclature of the Columbia River Basalt Group: U.S. Geol. Survey Bull. 1457-G, p. G44-G45 \\ 4. Olivine basalt, sparsely to moderately plagioclase-phyric \\ 6. $34 \mathrm{~m}$, range $<10-37 \mathrm{~m}$ \\ 7. Coarse-grained, three or more flows \\ 8. Informal basalt of Lewiston Orchards and basalt of Slippery Creek \\ 9. Overlies sandstone and basaltic conglomerate above Asotin Member; unconformably underlies Elephant Mountain Member \\ 10. Type locality: Roadcuts along Weissenfels Ridge, NW1/4 sec. 24 and NE1/4 sec. 23, T. 9 N., R. 46 E., Captain John Rapids quadrangle, Asotin County, Wash.}

\section{Welling Formation}

1. Late Ordovician

2. Oklahoma (EC)

3. Amsden, T. W., 1979, Welling Formation, new name for Upper Ordovician unit in eastern Oklahoma (formerly called "Fernvale"): Am. Assoc. Petroleum Geologists Bull., v. 63, no. 7 , p. $1135-1138$

4. Low-magnesium, organic-detrital limestone with minor detrital quartz

6. $6 \mathrm{~m}$, range $6-15 \mathrm{~m}$

7. Obscurely bedded, abundant fossil debris, widely distributed marker bed in subsurface

9. Replaces the name "Fernvale Limestone" in E Oklahoma. Overlies Fite Formation; underlies Sylvan Shale

10. Type section: W bluff of Illinois River at Horseshoe Bend, NE1/4NE1/4 sec. 36, T. $16 \mathrm{~N} .$, R. 22 E., $13 \mathrm{~km} \mathrm{~S}$ of Tahlequah and $5.2 \mathrm{~km} \mathrm{~S}$ of Welling, Cherokee County, Okla.

West Bath Member (Ammonoosuc Formation)

1. Middle Ordovician

2. New Hampshire (WC)

3. Prager, G. D., 1980, Stratigraphy of the Gardner Mountain area, New Hampshire: Northeastern Geology, v. 2, no. 1, p. 34

4. Calcareous schist

5. Blue-gray

7. Well-foliated, irregular cleavage surfaces which impart a lumpy appearance; weathers easily

9. Overlies Mullikin Brook Member; underlies Smutty Hollow or Lyman Member (Ammonoosuc Formation)

10. Type locality: Hillside $2.4 \mathrm{~km} \mathrm{SSW}$ of old West Bath School site, Grafton County, N.H.

West Fargo Member (Poplar River Formation)

1. Pleistocene (Wisconsinan)

2. Minnesota (WC), North Dakota

3. Arndt, B. M., 1977, Stratigraphy of of fshore sediment, Lake 
Agassiz--North Dakota: North Dakota Geol. Survey Rept. Inv. 60 , p. 6-8

4. Silt, clayey silt, peat

5. Dark-gray

6. $5.5 \mathrm{~m}$

7. Laminated; organic laminae; fluvial deposits

9. Unconformably overlies Brenna Formation or conformably overlies Harwood Member (Poplar River Formation); gradationally underlies Sherack Formation)

10. Type section: Composite borings 1, 2, and 3, F-2 Dormitory, Moorhead State College, SE1/4NE1/4SE1/4 sec. 8, T. $139 \mathrm{~N}$., R. 48 W., Moorhead, Clay County, Minn. Type area: Vicinity of Fargo, N. Dak. Named for town of West Fargo, Cass County.

Whiskers Creek Gneiss

1. Precambrian, early [Late Archean]

2. Michigan (NW)

3. Schmidt, R. G., 1976, Geology of the Precambrian W (lower Precambrian) rocks in western Gogebic County, Michigan:

U.S. Geol. Survey Bull. 1407, p. 8-14

4. Granodioritic gneiss, hornblendic metaconglomerate locally

7. Slightly foliated, derived from Ramsay Formation by contact metamorphism

9. Grades into Ramsay Formation away from Puritan Quartz Monzonite, which intrudes them; to $\mathrm{N}$, unconformably underlies early Precambrian strata

10. Type area: Outcrops near Anvil and Ramsay, and in area extending about $3 \mathrm{~km} \mathrm{SE}$ of Ironwood, including area along Whiskers Creek, T. 46 N., R. 47 W., Gogebic County, Mich.

Whiskey Butte Bed (Bridger Formation)

1. Eocene

2. Wyoming (SW)

3. Sullivan, Raymond, 1980, A stratigraphic evaluation of the Eocene rocks of southwestern Wyoming: Wyoming Geol. Survey Rept. Inv. 20, p. 40-41

4. Siltstone, mudstone, claystone

5. Gray to greenish

6. $70 \mathrm{~m} \max$

7. Fluvial unit at base of Bridger Formation along $W$ margin of Green River Basin.

9. Separated from main part of Bridger Formation by intertonguing Cow Hollow Bed (Laney Member of Green River Formation); overlies and intertongues with Craven Creek Bed (Laney Member of Green River Formation)

10. Type locality: Exposures in T. $21 \mathrm{~N} .$, R. $111 \mathrm{~W}$. , Whiskey Butte quadrangle, Lincoln County, Wyo.

White Throne Member (Temple Cap Sandstone)

1. Middle Jurassic

2. Utah (SW)

3. Peterson, Fred, and Pipiringos, G. N., 1979, Stratigraphic relations of the Navajo Sandstone to Middle Jurassic formations in parts of southern Utah and northern Arizona: U.S. Geol. Survey Prof. Paper 1035-B, p. B9-B10

4. Sandstone

5. Gray to orange 


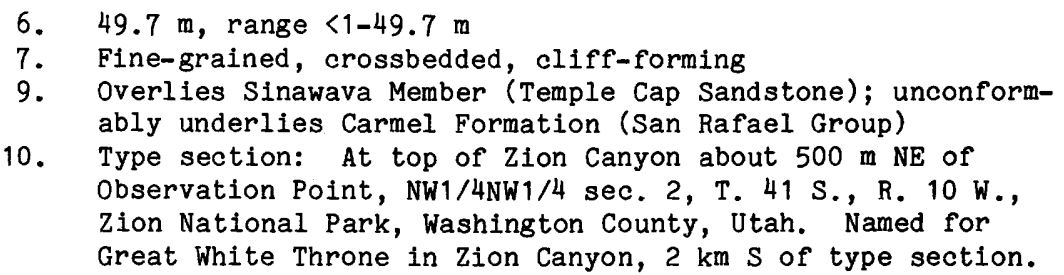

vilbur Creek Member (Saddle Mountains Basalt)

1. Miocene, middle

2. Washington (SE), Idaho

3. Swanson, D. A., and others, 1979, Revisions in stratigraphic nomenclature of the Columbia River Basalt Group: U.S. Geol. Survey Bull. 1457-G, p. G42

4. Sparsely plagioclase-phyric basalt

6. Range $<20->45 \mathrm{~m}$

7. Fine-grained

9. Conformably overlies Umatilla Member (Saddle Mountains Basalt) or unconformably overlies Priest Rapids Member (Wanapum Basalt); unconformably underlies Asotin Member (Saddle Mountains Basalt) (both formations in Yakima Basalt Subgroup of Columbia River Basalt Group)

10. Type locality: Roadcuts along Wilbur Creek, sec. 9 and SW1/4SW1/4 sec. 4, T. 14 N., R. 44 E., $7 \mathrm{~km} \mathrm{~W}$ of Pullman, Ewartsville quadrangle, Whitman County, Wash.

Uild Sheep Creek Formation (Seven Devils Group)

1. Middle and Late Triassic

2. Oregon (NE), Idaho

3. Vallier, T. L., 1977, The Permian and Triassic Seven Devils Group, western Idaho and northwestern Oregon: U.S. Geol. Survey Bull. 1437, p. 27-36

4. Metamorphosed basalt, basaltic andesite, and andesite flows and volcaniclastic graywacke, argillite, and limestone

5. Dark-green, greenish-black

6. $830 \mathrm{~m}$, range $440-2,500 \mathrm{~m}$

7. Rugged outcrops, pillow lavas, massive flows

9. Unconformably overlies Hunsaker Creek Formation; conformably underlies Doyle Creek Formation

10. Type section: Spur between Saddle and Hat Creeks, 425-900 m elevation, across Snake River from NE1/4 sec. $30, T .24$ N., R. 2 W. (in Adams County, Idaho), He-Devil quadrangle, Wallowa County, Oreg. Named for nearby Wild Sheep Creek.

Wilkie Ranch Formation

1. Early Permian (Leonardian)

2. Texas (WC)

3. Cys, J. M., 1976, Wilkie Ranch Formation, new Permian unit in Finlay Mountains: Am. Assoc. Petroleum Geologists Bull., v. 60 , no. 7 , p. $1107-1110$

4. Interbedded marlstone, limestone, and limestone conglomerate

5. Gray

6. Range 511-533 m.

7. Fossiliferous

9. Unconformably overlies Hueco Limestone; unconformably underlies Campagrande Formation

10. Type section: Measured Section 1 of Albritton, C. C., Jr., 
and Smith, J. F., Jr., 1965, U.S. Geol. Survey Prof. Paper 479 , p. 8-9, and Gulf 1 Burner-State "B" well, depthinterval 0-70 m, W Finlay Mountains, Hudspeth County, Tex. Named for nearby Wilkie Ranch.

\section{Wilson Ridge Formation (Chilhowee Group)}

1. Early Cambrian

2. Alabama (NE), Georgia

3. Mack, G. H., 1980, Stratigraphy and depositional environments of the Chilhowee Group (Cambrian) in Georgia and

Alabama: Am. Jour. Sci., v. 280, no. 6, p. 503, 514-515

4. Sandstone (orthoquartzite) facies interbedded with silty mudstone facies

5. Gray

6. $184 \mathrm{~m}$, range $10-425 \mathrm{~m}$

7. Tidal-flat deposits; crossbedded sandstone, ripple-laminated mudstone

9. Transitionally overlies Nichols Shale; conformably underlies Weisner Formation with sharp contact

10. Type section: Exposure on NE side of Cleburne County Highway 70 , between Piedmont and Borden Springs, NE1/4NE1/4 sec. 5, T. 13 S., R. 11 E., Cleburne County, Ala. Roadcut bisects Wilson Ridge.

Winchell Creek Siltstone Member (Great Meadows Formation)

1. Early Ordovician

2. New York (NE), Vermont

3. Fisher, D. W., 1977, Correlation of the Hadrynian, Cambrian and Ordovician rocks in New York State: New York State Mus. Map and Chart Ser., no. 25, p. 65

4. Dolomitic, quartzo-feldspathic siltstone

6. Range $<1-34 \mathrm{~m}$

7. Laminated, cross-stratified

9. Basal unit of Great Meadows Formation; transitionally underlies Fort Edward Dolostone Member

10. Type locality: Bushlea Farm, in pastures and abandoned quarry $\mathrm{N}$ of New York Highway 149 and $1.6 \mathrm{~km} \mathrm{E}$ of Smiths Basin on Champlain Canal, Hartford quadrangle, Washington County, N.Y. Named for Winchell Creek which flows into canal at Dewey Bridge.

\section{Wink Member (Wristen Formation)}

1. Late Silurian

2. Texas (WC)

3. Hills, J. M., and Hoenig, M. A., 1979, Proposed type sections for Upper Silurian and Lower Devonian subsurface units in Permian Basin, west Texas: Am. Assoc. Petroleum Geologists Bull., v. 63, no. 9, p. 1511

4. Limestone, dolomite, shale

5. White, gray

6. $41 \mathrm{~m}$, range $4.5-41 \mathrm{~m}$

7. Banded

9. Disconformably overlies Fusselman Shale; conformably underlies Frame Member (Wristen Formation)

10. Type section: Phillips Petroleum Co. 1 University Lands "H" well, depth-interval 5,355-5,396 m, Sec. 11, Blk. 17, University Lands Survey, War-Wink field, Winkler County, Tex. 


\section{Winterville Formation}

1. Ordovician (Caradocian and Ashgillian)

2. Maine (NC)

3. Roy, D. C., and Mencher, Ely, 1976, Ordovician and Silurian stratigraphy of northeastern Aroostook County, Maine: Geol. Soc. America Mem. 148, p. 34, 47

4. Andesitic, basaltic, keratophyric, rhyolitic, and tuffaceous volcanic rocks with interlayered slate, graywacke, and chert

6. $>1,500 \mathrm{~m}$

7. Complex assemblage of submarine volcanic and sedimentary rocks

9. Oldest rocks exposed in cores of anticlines; interfingers with Madawaska Lake Formation; disconformably(?) underlies Pyle Mountain Argillite or unconformably underlies Upper Silurian rocks

10. Type area: Along Maine Route 11, S of Winterville, Aroostook County, Maine.

Winthrop Till Member (Wolf Creek Formation)

1. Pleistocene (pre-Illinoian)

2. Iowa (EC)

3. Hallberg, G. R., 1980, Pleistocene stratigraphy in eastcentral Iowa: Iowa Geol. Survey Tech. Inf. Ser., no. 10, p. $54-64$

4. Silty till

5. Yellowish-brown to dark-gray

6. Range $<1.6-4.6 \mathrm{~m}$

7. Loam- to light clay-loam-textured till

9. Unconformably overlies informal Westburg paleosol and Alburnett Formation; underlies sediments which separate Winthrop from Aurora Till Member

10. Type locality: Railroad cut and Winthrop core section, $2 \mathrm{~km}$ $\mathrm{W}$ of town of Winthrop in $\mathrm{NW} 1 / 4 \mathrm{sec} .3, \mathrm{~T} .88 \mathrm{~N} ., \mathrm{R} .8 \mathrm{~W}$., Buchanan County, Iowa.

\section{Witch Member (Keating Formation)}

1. Early Mississippian

2. New Mexico (SW), Arizona

3. Armstrong, A. K., and Mamet, B. L., 1978, The Bugle and Witch Members of the Keating Formation, Escabrosa Group, and the Mississippian nomenclature in the Big Hatchet Mountains, Hidalgo County, New Mexico: U.S. Geol. Survey Bull. 1457-A, p. A92-A93

4. Limestone composed of spiculitic-pelletoid-bryozoan-echinoderm-lime mudstone to packstone and wackestone; chert

6. $82 \mathrm{~m}$

7. Cross-laminated, fossiliferous chert, nodular to lenticular

9. Overlies Bugle Member (Keating Formation); unconformably underlies Hachita Formation (Escabrosa Group)

10. Type section: E1/2 sec. 30, T. 29 S., R. 15 W., NE side of Big Hatchet Mountains, Hidalgo County, N. Mex. Named for Witch Well, Big Hatchet quadrangle.

Nolf Creek Formation

1. Plelstocene (pre-Illinoian)

2. Iowa (C)

3. Hallberg, G. R., 1980, Pleistocene stratigraphy in eastcentral Iowa: Iowa Geol. Survey Tech. Inf. Ser., no. 10, 


\section{p. $12-70$}

4. Till; fluvial silt, sand, and gravel; swale-fill deposits, peat, paleosols

7. Till units are loam-textured, and are high in expandable clays, kaolinite, and illite

8. Winthrop, Aurora, and Hickory Hills Till Members, and unnamed sediments between till members; informal Dysart paleosol between Aurora and Hickory Hills Till Members

9. Unconformably overlies Alburnett Formation and informal Westburg paleosol; underlies alluvium, swale-fill, fluvial, and pedisediment deposits of Yarmouth through late Sangamon age

10. Type area: Around Wolf Creek in Geneseo, Clark, Buckingham, and Grant Townships, Tama County, Iowa. Many outcrops and core holes in this area are designated reference sections for members.

Wolf Mountain Creek Formation (Emperor Volcanic Complex)

1. Precambrian X [Early Proterozoic]

2. Michigan (NW)

3. Trent, V. A., 1976, The Emperor Volcanic Complex of the East Gogebic Range, Michigan: U.S. Geol. Survey Bull. 1422-A, p. A69

4. Pyroclastic and tectonic flow-breccia, veined amygdaloidal lavas

5. Greenish-gray

6. Range $90-150 \mathrm{~m}$

7. Pillow structures, jointing

9. Overlies intertongued unnamed basalt flows of Emperor Volcanic Complex and lower members of Ironwood Ironformation; underlies Copps Formation

10. Type locality: Outcrops that flank Wolf Mountain Creek, tributary to Little Presque Isle River, secs. 14, 23, 24 , and 25, T. 47 N., R. 44 W., Wakefield NE quadrangle, Gogebic County, Mich.

\section{Urights Point Member (Harney Formation)}

\section{Pliocene}

2. Oregon (SE)

3. Walker, G. W., 1979, Revisions to the Cenozoic stratigraphy of Harney Basin, southeastern Oregon: U.S. Geol. Survey Bull. 1475, p. 30

4. Olivine basalt

6. 3-9 m

7. Two thin flows capping Wrights Point

9. Uppermost member of Harney Formation; overlies conglomerate tuffaceous sandstone and siltstone and ash beds of Harney Formation; top is Holocene erosion surface

10. Type locality: Roadcuts on Oregon State Highway 205 at Wrights Point, sec. 33, T. 24 S., R. 31 E., Harney County, Oreg.

Wristen Formation

1. Late Silurian

2. Texas (WC)

3. Hills, J. M., and Hoenig, M. A., 1979, Proposed type sections for Upper Silurian and Lower Devonian subsurface units in Permian Basin, west Texas: Am. Assoc. Petroleum 


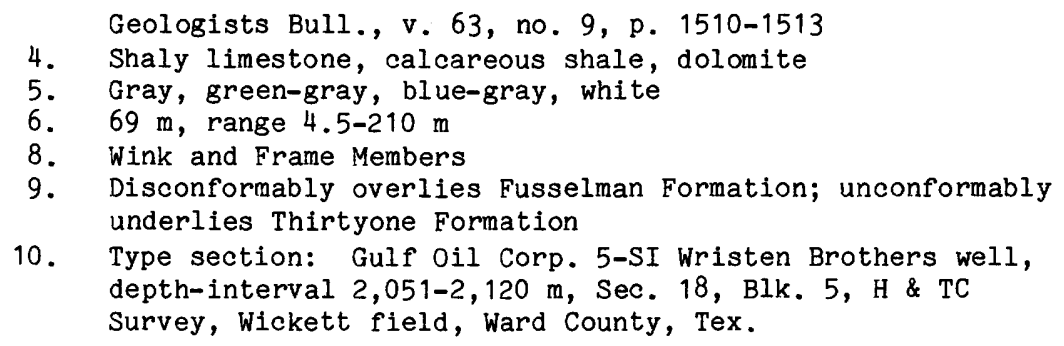

Wrong Mountain Quartz Monzonite (Santa Catalina Group)

1. Middle Proterozoic

2. Arizona ( $\mathrm{SC}$ )

3. Drewes, Harald, 1977, Geologic map and sections of the Rincon Valley quadrangle, Pima County, Arizona: U.S. Geol. Survey Misc. Inv. Ser. Map I-997

4. Quartz monzonite, biotite-muscovite gneiss

5. Light-brownish-gray

7. Large intrusive and metasomatic(?) complex. Texture ranges from massive near center of Rincon gneiss dome to mediumgrained with lit-par-lit sheets on flanks of dome

9. Intrudes Continental Granodiorite (Santa Catalina Group) and Pinal Schist

10. Type area: Sec. 9, T. 16 S., R. 18 E., most accessible along powerline service road on Wrong Mountain on S ridge of Rincon Mountains, Rincon Valley quadrangle, Pima County, Ariz.

\section{Yellow Dirt Gneiss}

1. Precambrian, late(?), and (or) Paleozoic, early(?)

2. Georgia (NW)

3. Higgins, M. W., and McConnell, K. I., 1978, The Sandy Springs Group and related rocks in the Georgia Piedmont-Nomenclature and stratigraphy: U.S. Geol. Survey Bull. 1457-A, p. A104-A105 (Also published in: Georgia Geol. Survey Bull. 93, p. 54, 1978)

4. Biotite-epidote-muscovite-quartz-plagioclase-microcline gneiss

5. Light-gray to pink

6. Range $75-240 \mathrm{~m}$

7. Fine- to medium-grained, cataclastic textures

9. In fault contact for long distances along SE boundary of Sandy Springs Group; everywhere fault-bounded

10. Type locality: Exposures near community of Yellow Dirt, Lowell quadrangle, Heard County, Ga.

\section{Zuma Volcanics}

1. Miocene, early and middle

2. California (SC)

3. Yerkes, R. F., and Campbell, R..H., 1979, Stratigraphic nomenclature of the central Santa Monica Mountains, Los Angeles County, California: U.S. Geol. Survey Bull. 1457-E, p. E27-E28

4. Basaltic and andesitic flows, breccias, tuffs; minor volcanic sediment and interbeds of mudstone and siltstone

6. Range $800-1,000 \mathrm{~m}$

7. Exposed in elongate fault slices 
9. Base nowhere exposed; inferred to unconformably overlie Catalina Schist; intertongues with Trancas Formation; intertongues with and underlies Monterey Shale

10. Type locality: Exposures on $\mathrm{W}$ side of Zuma Canyon, about 4 $\mathrm{km} \mathrm{N}$ of Point Dume, Santa Monica Mountains, SC Point Dume quadrangle, Los Angeles County, Calif. 



Prenty thend: 